Prepared for the U.S. Department of Energy

Under Contract DE-AC05-76RL01830

\title{
A Review of the Reflector Compact Fluorescent Lamps Technology Procurement Program: Conclusions and Results
}

\author{
LJ Sandahl MR Ledbetter \\ TL Gilbride JJ McCullough
}

May 2008

\section{Pacific Northwest}

NATIONAL LABORATORY 


\title{
DISCLAIMER
}

This report was prepared as an account of work sponsored by an agency of the United States Government. Neither the United States Government nor any agency thereof, nor Battelle Memorial Institute, nor any of their employees, makes any warranty, express or implied, or assumes any legal liability or responsibility for the accuracy, completeness, or usefulness of any information, apparatus, product, or process disclosed, or represents that its use would not infringe privately owned rights. Reference herein to any specific commercial product, process, or service by trade name, trademark, manufacturer, or otherwise does not necessarily constitute or imply its endorsement, recommendation, or favoring by the United States Government or any agency thereof, or Battelle Memorial Institute. The views and opinions of authors expressed herein do not necessarily state or reflect those of the United States Government or any agency thereof.

\author{
PACIFIC NORTHWEST NATIONAL LABORATORY \\ operated by \\ BATTELLE \\ for the \\ UNITED STATES DEPARTMENT OF ENERGY \\ under Contract DE-AC05-76RL01830
}

Printed in the United States of America

Available to DOE and DOE contractors from the Office of Scientific and Technical Information,

P.O. Box 62, Oak Ridge, TN 37831-0062;

ph: (865) 576-8401

fax: (865) 576-5728

email: reports@adonis.osti.gov

\author{
Available to the public from the National Technical Information Service, \\ U.S. Department of Commerce, 5285 Port Royal Rd., Springfield, VA 22161 \\ ph: (800) 553-6847 \\ fax: $(703) 605-6900$ \\ email: orders@ntis.fedworld.gov \\ online ordering: http://www.ntis.gov/ordering.htm
}

Electronic copies of the report are also available from the DOE Solid State Lighting website at http://www.netl.doe.gov/ssl/

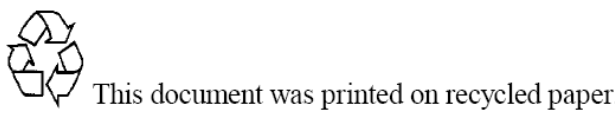

$(9 / 2003)$ 


\title{
A Review of the Reflector Compact Fluorescent Lights Technology Procurement Program: Conclusions and Results
}

\author{
LJ Sandahl \\ TL Gilbride \\ MR Ledbetter \\ JJ McCullough
}

Final Report

May 2008

Prepared for

The U.S. Department of Energy

Office of Building Technologies

Under Contract DE-AC05-76RLO 1830

Pacific Northwest National Laboratory

Richland, Washington 99352 



\begin{abstract}
This report describes a project sponsored by the U.S. Department of Energy (DOE) and implemented by the Pacific Northwest National Laboratory (PNNL) from 2001 to 2007 to improve the performance and availability of reflector type (R-lamp) compact fluorescent lamps (CFLs). The program achieved the following:
\end{abstract}

- Identified 16 R-CFL models verified to operate reliably in ICAT environments. Several of these models were new product introductions.

- developed test procedure (ETLT) widely recognized by utilities as the best way to verify performance in high temp environments

- laid the groundwork for new R-CFL ENERGY STAR requirements and test procedures

- substantially raised the profile of R-CFL performance issues; caused many organizations, including test labs, manufacturers, NEMA, utilities and others to investigate issue and change business practices

- caused major retailers to demand PNNL testing for any lamps they carried

- locked in long-term effects of project by getting new R-CFL requirements written into ENERGY STAR

- effectively transformed the market, non-participating manufacturers are now producing R-CFLs that meet the program requirements in response to market forces. 


\section{Executive Summary}

This report describes a project sponsored by the U.S. Department of Energy (DOE) and implemented by the Pacific Northwest National Laboratory (PNNL) from 2001 to 2007 to improve the performance and availability of reflector type (R-lamp) compact fluorescent lamps (CFLs) designed to be an energyefficient replacement for screw-based incandescent reflector style lamps in recessed can, and flood light fixtures.

DOE and PNNL identified an important gap in the residential lighting market: a lack of CFLs suitable for the most commonly installed residential fixture type, recessed downlights. Recessed downlights are among today's most popular lighting fixtures with an estimated 450 to 500 million installed in U.S. homes. The vast majority of these fixtures are fitted with incandescent reflector lamps (R-lamps), typically drawing 65 to 100 watts of power per lamp. When the DOE R-CFL technology procurement project started in 2001, there were very few R-CFL models available and those that were available were very expensive and had performance problems, due especially to the high temperatures that could occur in insulated ceiling rated airtight (ICAT) recessed can fixtures. To work in this application, CFLs would need to be: 1) reflector shaped, to direct light out of the can, and 2) able to withstand high temperatures, always a challenge for electronic components.

In 2001, at the request of the U.S. Department of Energy's Emerging Technologies Program and its predecessors, the Pacific Northwest National Laboratory undertook the R-CFL technology procurement. PNNL crafted technical specifications for this application and invited the lamp industry to meet the specified performance levels which included minimum light output and size limits. PNNL also identified a significant gap in the industry standard test procedures available to evaluate lamp performance: traditional lamp ratings, conducted at ambient temperature of $25^{\circ} \mathrm{C}$, were inadequate to predict the performance of reflector lamps in insulated recessed can fixtures. In response, PNNL worked with an independent testing laboratory to develop an elevated temperature life test (ETLT) to accurately measure R-CFLs. This test procedure was based on existing industry standard test procedures published by the IESNA and accepted test environments defined by UL.

PNNL issued the first request for proposals in October 2002 and five manufacturers responded with 12 lamp models. These models had to meet minimum requirements light output, beam angle, maximum operating temperature, and length, and pass a 6-hour short-term test in a simulated ICAT environment, then they were subjected to long-term tests in the elevated temperature environment for their rated life of 6,000, 8,000, or 10,000 hours in a testing apparatus developed by PNNL and the testing laboratory. The outcome of the first solicitation was disappointing. While nine products passed the short-term tests and moved to ETLT, only three products passed the long-term performance test, while six others failed after less than half their rated life. DOE and PNNL felt that three successful products were not enough to change the market.

PNNL undertook an in-depth investigation to figure out why so many lamps were failing early. Manufacturers pointed to the electrolytic capacitor as the likely culprit, but detailed post-mortem examination of failed lamps found this was not the case. In fact it was not the electronics but the lamps that were failing first. The electronics then overheated and failed as they continued to try to start the failed lamps. As a result of this investigation, PNNL proposed several measures to improve R-CFL performance: limiting the lamp current crest factor, improving high-frequency circuit designs to prevent damage from high voltages, and adding end of lamp life circuitry to avoid electronic component failure. 
These technical recommendations were communicated to the lamp industry through presentations, conference calls, and meetings.

To increase the number of qualifying models, a second RFP was issued in June 2005. This solicitation resulted in many more qualifying lamps: 31 models were submitted and 13 models passed which, combined with the three winners from the first phase 1 , totaled 16 winning models offered by four manufacturers (see Table S.1).

PNNL has promoted the winning lamps through the program website (www.pnl.gov/rlamps), press releases, fact sheets, 26 articles in trade press, two ACEEE Summer Study papers, other conference presentations, and links from other websites and the winning models are available at a variety of retail locations and from the Energy Federation Incorporated (EFI) (www.energyfederation.org/).

Qualifying R-CFLs are now readily available at major retailers, at competitive prices. Through the program, PNNL developed relationships with major retailers including Costco, Lowes, and Home Depot. In 2007, Costco began requiring successful completion of PNNL's ETLT for R-CFLs carried in Costco stores nationwide. Costco carries the Feit R-CFL models included in the DOE program at a very competitive price of $\$ 12.99 / 4$ pack. Since Costco is one of the largest suppliers of R-CFLs, the impact of this requirement is huge.

Numerous utility companies and energy efficiency organizations across the United States have supported the program because of the early performance problems with this category of CFLs. The product specifications and testing procedures developed by PNNL for the R-CFL procurement were adopted as the qualifying criteria for inclusion in numerous R-CFL rebate programs sponsored by utilities in 2006 and 2007. Numerous utilities such as the Sacramento Municipal Utility District (SMUD) and the Bonneville Power Administration provided rebates only on R-CFLs that were qualified in the DOE RCFL program. For example BPA ran an incentive program in 2007 that required models to meet our Phase 2 requirements. The program sold 517,000 lamps between February 15, 2007, and July 1, 2007.

The criteria and the ETLT test apparatus design developed by PNNL have been included by DOE in its ENERGY STAR specifications for the reflector category of CFLs. These specifications were issued in March 2008 and take effect on December 2, 2008.

The DOE R-CFL program was successful in transforming the market. It has become self-sustaining. Other manufacturers are producing compliant models because of demand from retailers who require that any R-CFLs they sell "pass the PNNL testing" and energy-efficiency groups that provide monetary incentives solely for products that have passed the PNNL-developed elevated temperature life testing. The DOE R-CFL program was successful in transforming the market. It has become self-sustaining, and DOE is closing the project and web site in December 2008 when the revised ENERGY STAR specification takes effect. . 
Table S.1. R-CFL Technology Innovation Competition Winners - Quick Facts

\begin{tabular}{|c|c|c|c|c|c|c|c|c|c|c|c|}
\hline & Model & Lumens & Wattage & $\begin{array}{l}\text { Power } \\
\text { Factor }\end{array}$ & $\begin{array}{c}\text { Rated } \\
\text { Average Life }\end{array}$ & $\begin{array}{l}\text { Color } \\
\text { Temp }\end{array}$ & $\begin{array}{c}\text { Minimum/Operating } \\
\text { Temperature }\end{array}$ & CRI & $\begin{array}{l}\text { Length } \\
\text { (inches) }\end{array}$ & Warranty & Dimming \\
\hline 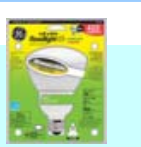 & $\begin{array}{l}\text { GE FLE15/2/DV R30 } \\
15 \text { Watt Dimmable }\end{array}$ & 720 & $15 W$ & 0.6 & 6,000 hours & $2700 \mathrm{~K}$ & $\begin{array}{l}\text { Minimum Starting } \\
\text { Temperature: } 5^{\circ} \mathrm{F}\end{array}$ & 82 & 5.6 & 4 years & Yes \\
\hline 5 & $\begin{array}{l}\text { GE FLE15/2/R30XL } \\
15 \text { Watt Reflector Flood }\end{array}$ & 750 & $15 W$ & 0.6 & 10,000 hours & $2700 \mathrm{~K}$ & $\begin{array}{l}\text { Minimum Starting } \\
\text { Temperature: } 5^{\circ} \mathrm{F}\end{array}$ & 82 & 5.5 & 7 years & No \\
\hline & $\begin{array}{l}\text { Philips EL/A BR30 } \\
16 \text { Watt Reflector Flood }\end{array}$ & 630 & $16 W$ & $>0.50$ & 8,000 hours & $2700 \mathrm{~K}$ & $\begin{array}{l}\text { Operating Range: } \\
-10^{\circ} \text { to } 140^{\circ} \mathrm{F}\end{array}$ & 82 & 5.4 & 7 years & No \\
\hline & $\begin{array}{l}\text { Feit ESL15R30H } \\
15 \text { Watt Reflector Flood }\end{array}$ & 750 & $15 W$ & 0.638 & 8,000 hours & $2700 K$ & $\begin{array}{l}\text { Minimum Starting } \\
\text { Temperature: }-27^{\circ} \mathrm{F}\end{array}$ & 82 & 5.1 & $\begin{array}{l}2 \text { years res; } \\
1 \text { year com }\end{array}$ & No \\
\hline$\psi$ & $\begin{array}{l}\text { GE FLE26/2/PAR38/XL } \\
26 \text { Watt Reflector Flood }\end{array}$ & 1300 & $26 W$ & 0.6 & 10,000 hours & $2700 \mathrm{~K}$ & $\begin{array}{l}\text { Minimum Starting } \\
\text { Temperature: } 5^{\circ} \mathrm{F}\end{array}$ & 82 & 5.6 & 6 years & No \\
\hline (5) & $\begin{array}{l}\text { Philips EL/A PAR38 } \\
20 \text { Watt Reflector Flood }\end{array}$ & 930 & $20 W$ & $>0.55$ & 8,000 hours & $2700 \mathrm{~K}$ & $\begin{array}{l}\text { Operating Range: } \\
-10^{\circ} \text { to } 140^{\circ} \mathrm{F}\end{array}$ & 82 & 5.67 & 7 years & No \\
\hline & $\begin{array}{l}\text { Philips EL/A PAR38 } \\
23 \text { Watt Reflector Flood }\end{array}$ & 1250 & $23 W$ & & 8,000 hours & $2700 \mathrm{~K}$ & $\begin{array}{l}\text { Operating Range: } \\
-22^{\circ} \text { to } 140^{\circ} \mathrm{F}\end{array}$ & 82 & 5.87 & 7 years & No \\
\hline 5 & $\begin{array}{l}\text { Feit ESL18 PAR38H } \\
18 \text { Watt Reflector Flood }\end{array}$ & 950 & $18 W$ & 0.68 & 8,000 hours & $2700 K$ & $\begin{array}{l}\text { Minimum Starting } \\
\text { Temperature: }-20^{\circ} \mathrm{F}\end{array}$ & 82 & 5.8 & $\begin{array}{l}2 \text { years res; } \\
1 \text { year com }\end{array}$ & No \\
\hline
\end{tabular}




\begin{tabular}{|c|c|c|c|c|c|c|c|c|c|c|c|}
\hline & $\begin{array}{l}\text { Feit BPCE23PAR38/3 } \\
23 \text { Watt Reflector Flood }\end{array}$ & 1300 & $23 \mathrm{~W}$ & 0.66 & 8,000 hours & $2700 \mathrm{~K}$ & $\begin{array}{l}\text { Minimum Starting } \\
\text { Temperature: }-27^{\circ} \mathrm{F}\end{array}$ & 82 & 6.2 & $\begin{array}{l}2 \text { years res; } \\
1 \text { year com }\end{array}$ & No \\
\hline & $\begin{array}{l}\text { Sylvania CFE19PAR38 } \\
19 \text { Watt Reflector Flood }\end{array}$ & 900 & $19 \mathrm{~W}$ & $>0.50$ & 10,000 hours & $3000 \mathrm{~K}$ & $\begin{array}{l}\text { Minimum Starting } \\
\text { Temperature: }-18^{\circ} \mathrm{C}\end{array}$ & 82 & 6.6 & & No \\
\hline & $\begin{array}{l}\text { GE FLE26/2/R40/XL } \\
26 \text { Watt Reflector Flood }\end{array}$ & 1300 & $26 \mathrm{~W}$ & 0.6 & 10,000 hours & $2700 \mathrm{~K}$ & $\begin{array}{l}\text { Minimum Starting } \\
\text { Temperature: } 5^{\circ} \mathrm{F}\end{array}$ & 82 & 6.5 & 7 years & No \\
\hline \$ & $\begin{array}{l}\text { Philips EL/A BR40 } \\
20 \text { Watt Reflector Flood }\end{array}$ & 940 & $20 \mathrm{~W}$ & $>0.55$ & 8,000 hours & $2700 \mathrm{~K}$ & $\begin{array}{l}\text { Operating Range: } \\
-10^{\circ} \text { to } 140^{\circ} \mathrm{F}\end{array}$ & 82 & 5.7 & 7 years & No \\
\hline & $\begin{array}{l}\text { Philips EL/A R40 } \\
23 \text { Watt Reflector Flood }\end{array}$ & 1250 & $23 \mathrm{~W}$ & $>0.55$ & 8,000 hours & $2700 \mathrm{~K}$ & $\begin{array}{l}\text { Operating Range: } \\
-22^{\circ} \text { to } 140^{\circ} \mathrm{F}\end{array}$ & 82 & 5.7 & 7 years & No \\
\hline I & $\begin{array}{l}\text { Feit ESL 18R40H } \\
18 \text { Watt Reflector Flood }\end{array}$ & 950 & $18 \mathrm{~W}$ & 0.66 & 8,000 hours & $2700 K$ & $\begin{array}{l}\text { Minimum Starting } \\
\text { Temperature: }-20^{\circ} \mathrm{F}\end{array}$ & 82 & 5.8 & $\begin{array}{l}2 \text { years res; } \\
1 \text { year com }\end{array}$ & No \\
\hline & $\begin{array}{l}\text { Feit BPCE23R40/3 } \\
23 \text { Watt Reflector Flood }\end{array}$ & 1300 & $23 \mathrm{~W}$ & 0.65 & 8,000 hours & $2700 \mathrm{~K}$ & $\begin{array}{l}\text { Minimum Starting } \\
\text { Temperature: }-27^{\circ} \mathrm{F}\end{array}$ & 82 & 6.2 & $\begin{array}{l}2 \text { years res; } \\
1 \text { year com }\end{array}$ & No \\
\hline (3) & $\begin{array}{l}\text { Sylvania CFEL20BR40 } \\
20 \text { Watt Reflector Flood }\end{array}$ & 900 & $20 \mathrm{~W}$ & $>0.50$ & 8,000 hours & $3000 \mathrm{~K}$ & $\begin{array}{l}\text { Minimum Starting } \\
\text { Temperature }-18^{\circ} \mathrm{C}\end{array}$ & 82 & 6.6 & & No \\
\hline
\end{tabular}




\section{Contents}

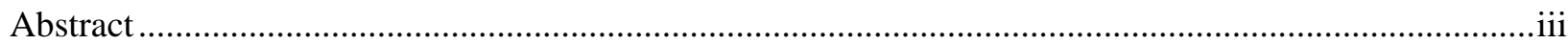

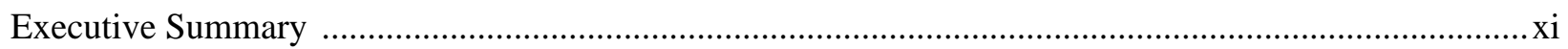

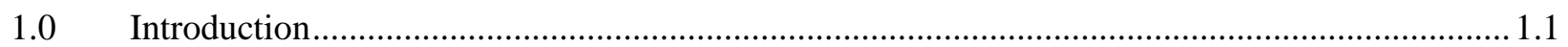

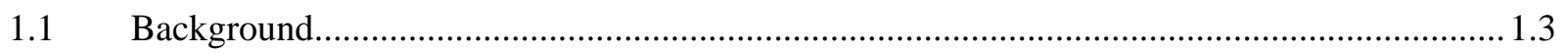

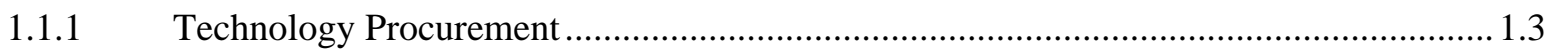

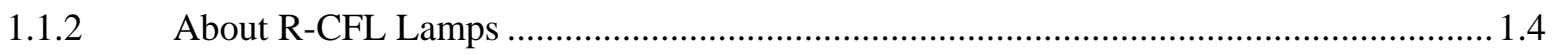

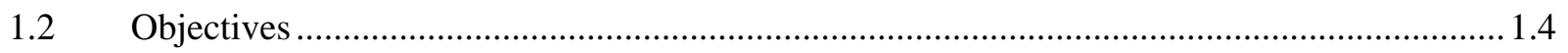

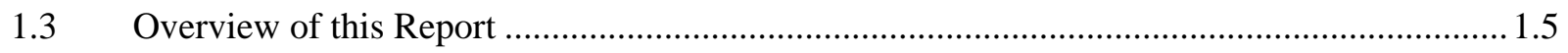

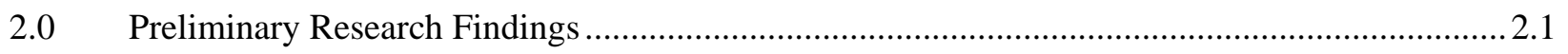

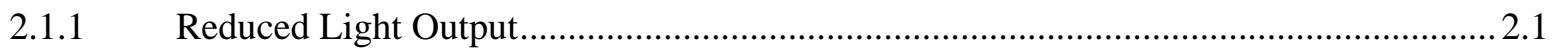

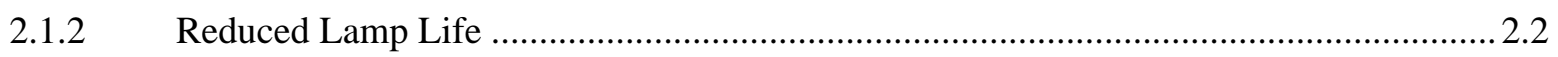

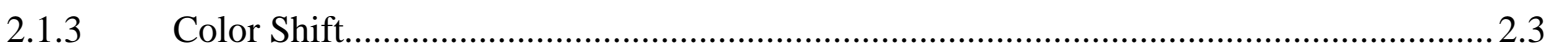

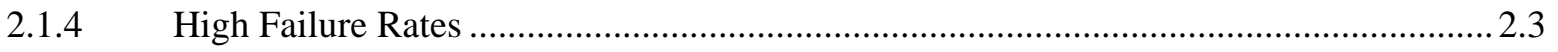

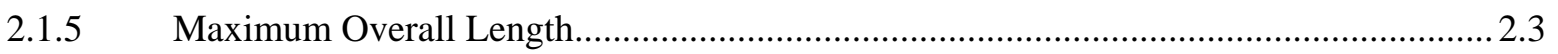

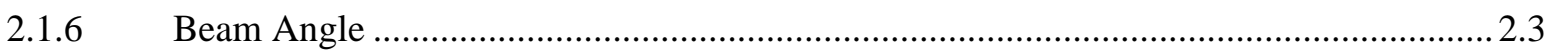

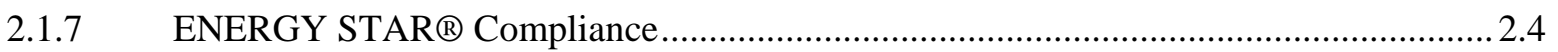

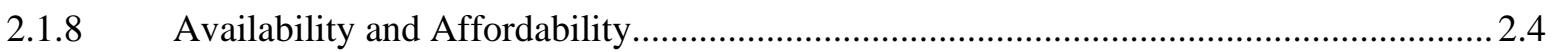

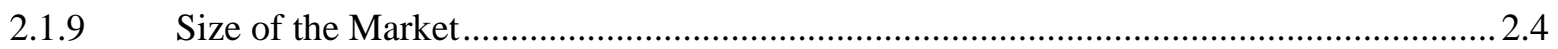

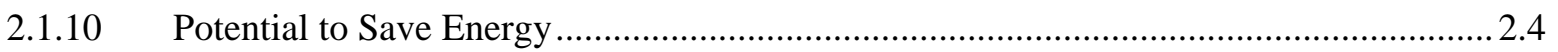

3.0 Phase 1 Request for Proposal Development and Overview ....................................................... 3.1

3.1 Phase 1 ENERGY STAR and Minimum Requirements..................................................... 3.1

3.2 Phase 1 Short-Term Laboratory Test Procedure ................................................................. 3.3

3.3 Phase 1 Elevated Temperature Life Testing ......................................................................... 3.4

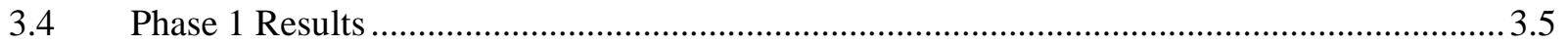

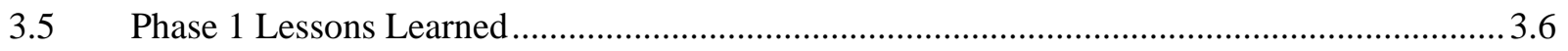

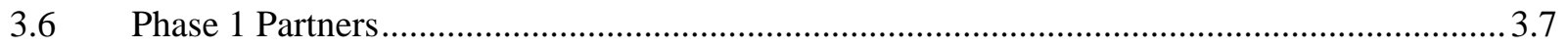

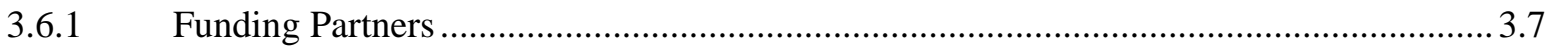

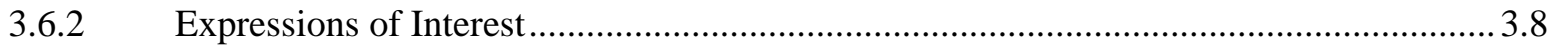

4.0 R-CFL Technology Procurement Phase 2 .............................................................................. 4.1

4.1 Phase 2 Minimum Technical Requirements ......................................................................... 4.1

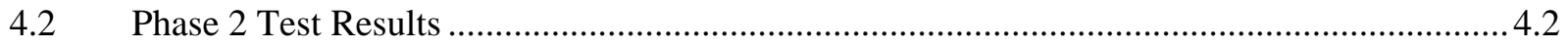

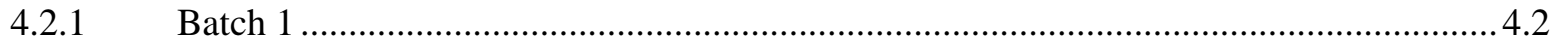




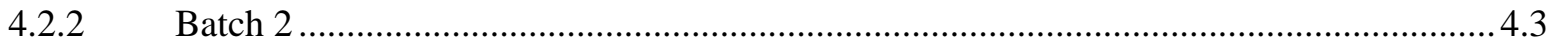

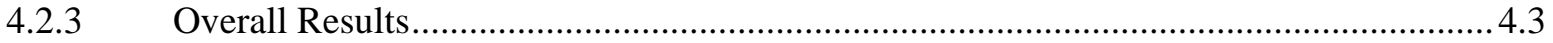

4.5 Phase 2 Technology Innovation Competition Support...................................................... 4.7

5.0 Partner Involvement, Outreach, Program Promotion.............................................................. 5.1

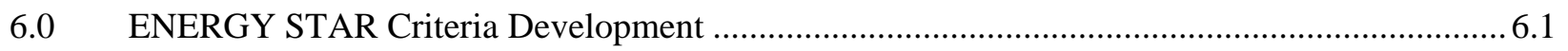

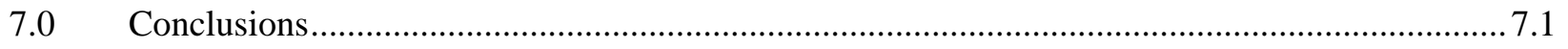

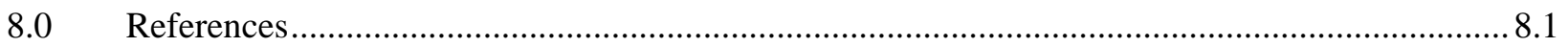

Appendix A - Outreach (activities, press releases, list of articles, fact sheets) ..................................... A.1

Appendix B - Survey of Lighting Retailers: CFL R-30 Lamp Questionnaire Results...............................1

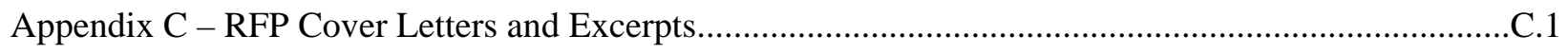

Appendix D - R-Lamps Savings Calculator............................................................................... D.1

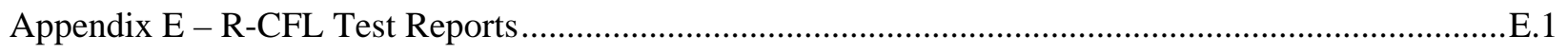

Appendix F - Procedures for Safely Cleaning up a Broken CFL ........................................................F.1 


\section{Figures}

Figure 1.1. An A-Lamp or Edison-Replacement Style CFL and an R-CFL Reflector

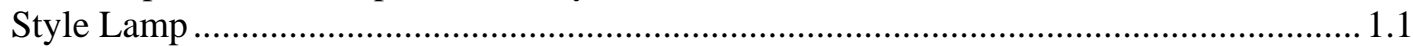

Figure 1.2. Technology Procurement is an Effective Method for Pulling New Energy Efficient Products into the Market..................................................................... 1.4

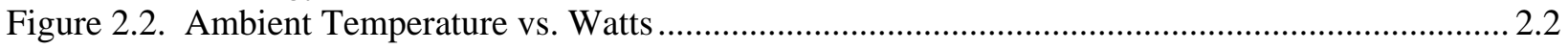

Figure 2.1. When Edison A Lamps or CFLs are used in a Recessed Can Fixture 50\% of the Light Emitted by the Lamp Is Lost in the Can......................................................... 2.1

Figure 3.1. Short-Term Test Apparatus for Phase 1 and Phase 2 Short-Term Testing Used by Luminaire Testing Laboratory, Inc. ........................................................................ 3.4

Figure 3.2. Drawing of the Elevated Temperature Life Testing Apparatus............................................. 2.2

\section{Tables}

Table 1.1. Timeline of Key Events of R-CFL Technology Procurement .............................................. 1.2

Table 2.1. R-CFLs - Three Lighting Energy Savings Examples Using the R-Lamp Savings Calculator

Table 3.1. Phase 1 Minimum Requirements for R-CFLs for Insulated Ceiling, Airtight Fixtures

Table 3.2. Elevated-Temperature Life Testing - Phase 1 Results ...

Table 4.1. Phase 2 Minimum Requirements for R-CFLs for Insulated Ceiling, Airtight Fixtures

Table 4.2. Phase 2 Batch 1 ETLT Results 4.4

Table 4.3. Phase 2 Batch 2 ETLT Results 4.5

Table 4.4. R-CFL Technology Innovation Competition Winners 4.6 


\subsection{Introduction}

Recessed downlights (also known as recessed can lights) are an enormously popular fixture in residential buildings today. Recessed "cans" are relatively inexpensive fixtures, fit with any décor, and provide an unobtrusive, directed light source. Unfortunately most are fitted with incandescent reflector lamps (Rlamps) typically drawing 65 to 100 watts of power per lamp.

Many incandescent R-lamps can be replaced with compact fluorescent reflector lamps (R-CFLs), which provide similar light output while using just one-third the energy. In non-airtight cans, screw-in CFLs can replace incandescent lamps for immediate energy savings. However, much of the light from a standard CFL will be lost inside the recessed fixture. Reflector-style CFLs address this problem (see Figure 1.1); however, when this project started in 2001, there were very few R-CFL models available in consumer markets. Further, there were performance problems with the R-CFL models that were available, especially when they were used in insulated ceiling rated airtight (ICAT) recessed can fixtures. The lamps were not able to tolerate the high temperatures inside the insulated cans and many lamps exhibited reduced light output and early burnout.
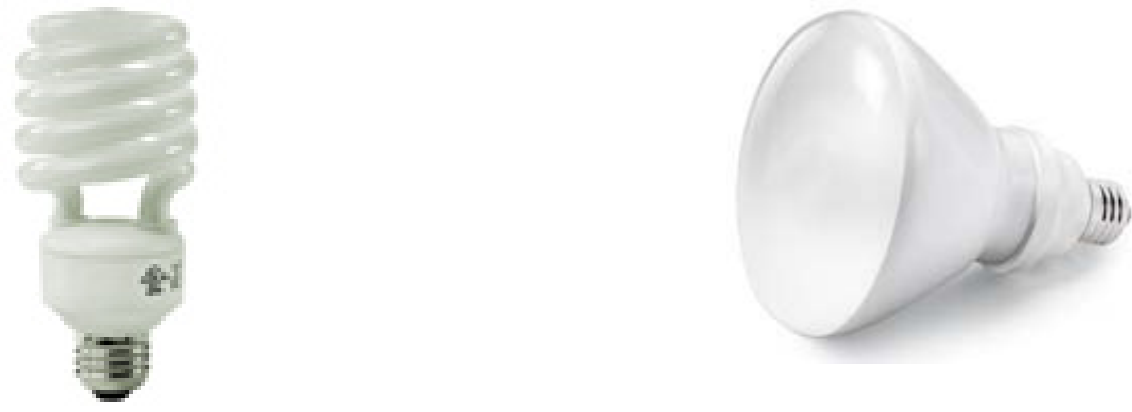

Figure 1.1. An A-Lamp or Edison-Replacement Style CFL and an R-CFL Reflector Style Lamp

In 2001, at the request of the U.S. Department of Energy’s Emerging Technologies Program, the Pacific Northwest National Laboratory (PNNL) undertook a technology procurement seeking CFLs that could replace the incandescent lamps in these can light fixtures. The CFLs would need to be reflector style with the lamp designed to direct the light downward out of the can. The lamps also needed to withstand the high temperatures found in recessed can fixtures located in insulated environments like ceilings below an attic. The lamps would also be required to meet other minimum performance criteria including minimum light output and size restrictions (to ensure they fit in standard residential recessed cans).

This report documents PNNL's efforts in support of the R-CFL procurement from the beginning of the program in FY 2001 to its conclusion in FY 2008. A timeline showing the key events of Phase 1 and Phase 2 of the procurement is shown in Table 1.1. 
Table 1.1. Timeline of Key Events of R-CFL Technology Procurement

\begin{tabular}{|l|l|}
\hline Fall 2000 & R-CFLs identified by PNNL as a candidate for technology procurement \\
\hline Spring 2001 & $\begin{array}{l}\text { PNNL begins meeting with lighting manufacturers, manufacturer trade } \\
\text { associations, suppliers, and potential large-volume buyers including builders, } \\
\text { home centers, and government agencies to seek technical guidance and to } \\
\text { generate interest in the procurement. }\end{array}$ \\
\hline Oct 2001 & $\begin{array}{l}\text { PNNL completes draft report Reflector Lamp and Dimmable Compact } \\
\text { Fluorescent Lamp Product Procurement Issues and sends to DOE and the } \\
\text { Northwest Energy Efficiency Alliance for review. }\end{array}$ \\
\hline April 2002 & Draft CFL R-Lamp specifications distributed to industry for comment. \\
\hline March 2002 & Web site for CFL reflector products developed, www.pnl.gov/R-Lamps-rfp \\
\hline October 25, 2002 & Phase 1 RFP issued. \\
\hline November 22, 2002 & Phase 1 proposals due. \\
\hline July 22, 2002 2003 & $\begin{array}{l}\text { Five manufacturers submitted 12 models. One failed to meet minimum PNNL } \\
\text { program criteria and ENERGY STAR requirements. Remaining 11 models sent } \\
\text { to short-term testing at Luminaire Testing Laboratory, Inc. }\end{array}$ \\
\hline $\begin{array}{l}\text { Spring-Summer } \\
\text { 2003 }\end{array}$ & $\begin{array}{l}\text { PNort-term testing completed. Eight models by three manufacturers selected for } \\
\text { long-term testing. }\end{array}$ \\
\hline September 9, 2003 & Phase 1 long-term testing starts. \\
\hline June 17, 2004: & $\begin{array}{l}\text { Two lamp models (by Philips) complete long-term testing (at 6,000 hours rated } \\
\text { life). }\end{array}$ \\
\hline June 30, 2004 & Lighting expert hired by PNNL completes evaluation of failed lamps. \\
\hline July 29, 2004 & $\begin{array}{l}\text { Two models that completed 6,000 hours of ETLT are announced as winners of } \\
\text { Phase 1. PNNL starts to promote both lamps (by through the R-CFL web site } \\
\text { (www.pnl.gov/rlamps) and Philips partners with The Home Depot Supply to } \\
\text { offer the models through Home Depot's website. }\end{array}$ \\
\hline Two Phase 1 models complete 8,000 hours of long-term testing. \\
\hline March 11, 2005 & $\begin{array}{l}\text { Onase 2 Draft RFP released for review/comment. } \\
\text { Phase 1 winner. }\end{array}$ \\
\hline May 2005 & andelop long-term testing procedure. \\
\hline
\end{tabular}




\begin{tabular}{|l|l|}
\hline June 3, 2005 & Phase 2 RFP released to industry. \\
\hline $\begin{array}{l}\text { July 18 to August } \\
\text { 29, 2005 }\end{array}$ & Phase 2 Batch 1 Proposals receipt period, 15 models received. \\
\hline $\begin{array}{l}\text { August 29, 2005, to } \\
\text { January 6, 2006 }\end{array}$ & Phase 2 Batch 2 receipt period, 16 models received. \\
\hline November 1, 2005 & $\begin{array}{l}\text { Phase 2 short-term elevated temperature evaluations complete for Batch 1; 10 } \\
\text { models submitted for ETLT. }\end{array}$ \\
\hline January 4, 2006 & Phase 2 Batch 1 ETLT begins. \\
\hline June 2006 & ETLT for Phase 2 Batch 2 begins. \\
\hline October 11, 2006 & $\begin{array}{l}\text { ETLT completed for 6,000 hour rated lamps (Batch 1). Winners announced and } \\
\text { promotion begins. }\end{array}$ \\
\hline Jan 17, 2007 & ETLT completed for 8,000-hour rated lamps (Batch 1). \\
\hline April 25, 2007 & ETLT completed for 10,000-hour rated lamps (Batch 1). \\
\hline July 2007 & ETLT completed for Batch 2 lamps. \\
\hline May 2007 & Final test data posted to website. \\
\hline Oct 2007 & ETLT reports updated for manufacturers and website. \\
\hline
\end{tabular}

\subsection{Background}

Since 1993, PNNL has assisted DOE's Emerging Technologies Program, and its predecessors, in its efforts to improve the energy efficiency of the U.S. buildings sector by encouraging the commercialization of energy-efficient appliances and equipment. One method PNNL has used to achieve faster market acceptance of new energy-efficient products is technology procurement. R-CFLs were identified as a candidate for technology procurement in Fall 2000. In Spring 2001, PNNL began meeting with potential large-volume buyers including builders, home centers, and government agencies to seek technical guidance and help with program design and to generate interest in the procurement. PNNL also met with product manufacturers, manufacturer trade associations, and suppliers to solicit their guidance and knowledge and to inform them of the upcoming procurement.

\subsubsection{Technology Procurement}

PNNL has applied the technology procurement approach to a number of projects for DOE. Technology procurement is a method to "pull" new technologies and products into the marketplace through competitive procurements backed by large-volume buyers (see Figure 1.2). First, an appliance category with good potential for energy-efficiency improvement is identified and, with input from industry and its partners, product specifications are defined. PNNL then issues a Request for Proposals (RFP) asking manufacturers to submit bids to produce models of the appliance that meet the procurement's high performance and energy-efficiency requirements at the lowest possible price. At least one draft proposal is typically released before the final, so that manufacturers can comment on it. PNNL, on behalf of DOE, works with potential large-volume buyers and supporters (i.e., utilities and market transformation groups) to promote the winning products through retailer and consumer education programs. This approach lessens the risks manufacturers normally take with new product development by establishing initial product demand estimates, sponsoring consumer education efforts, and promoting the new technology through large-volume retailers, utilities, and energy-efficiency organizations. PNNL has used this approach to successfully promote market acceptance of several energy-efficient technologies for DOE, including energy-efficient refrigerators, resource-efficient clothes washers, high-performance roof-top air conditioners, and compact fluorescent screw-based light bulbs. 


\begin{tabular}{|c|c|c|c|c|}
\hline $\begin{array}{l}\text { Identify } \\
\text { Appliance } \\
\text { Category } \\
\end{array}$ & \begin{tabular}{|c|} 
Define \\
Product \\
Specifications
\end{tabular} & $\begin{array}{c}\text { Issue } \\
\text { Draft RFP to } \\
\text { Manufacturers }\end{array}$ & $\begin{array}{l}\text { Issue Final } \\
\text { RFP to } \\
\text { Manufacturers }\end{array}$ & $\begin{array}{l}\text { Work with Volume Buyers, } \\
\text { Retailers, Utilities, etc. to } \\
\text { Promote Winning Products }\end{array}$ \\
\hline
\end{tabular}

Figure 1.2. Technology Procurement is an Effective Method for Pulling New Energy Efficient Products into the Market

\subsubsection{About R-CFL Lamps}

Recessed downlights are among today's most popular lighting fixtures with an estimated 450 to 500 million installed in U.S. homes. An estimated 120 to 140 million R-lamps are sold in the United States each year. Roughly half of these are for residential use. Why are they so popular? Recessed "cans" are relatively inexpensive compared to other types of installed lighting fixtures for the home, fit with any décor, and provide an unobtrusive, directed source of light for kitchens, hallways, and living rooms. Commercial buildings, such as restaurants, hotels, and multifamily housing facilities, are also often equipped with recessed can fixtures. Apartment buildings and hotels, for example, often use recessed cans in common areas like hallways, lobbies, and reception areas, many of which remain lit for extended hours.

Energy use in all of these applications could be reduced significantly by using R-CFLs instead of incandescent reflector lamps. However, when the project started, there were very few R-CFL models available and those that were available had performance issues including low light output and early burnout. When higher wattage R-CFLs are used in an insulated ceiling rated airtight (ICAT) recessed can, heat generated by the lamp and ballast can be trapped inside the fixture, and excessive heat can cause lower light output and a shorter life span.

To address the heat challenge, this procurement sought R-CFLs that were specifically designed for use in ICAT recessed can fixtures and met other performance criteria including minimum light output and size restrictions (to ensure they fit in standard residential recessed cans). While the project focused on developing R-CFLs for ICAT cans, the models selected will perform equally well in non-ICAT cans, track lighting fixtures, and even as wall-mounted flood lights. R-CFLS are not recommended for spotlight applications where a narrow, directed beam is required. Because fluorescent lamps are diffuse, as opposed to point light sources, they are not appropriate for applications requiring tightly focused beams of light.

\subsection{Objectives}

The purpose of this project was to increase the availability and use of highly energy-efficient R-CFLs for use in ICAT fixtures. Specifically, the procurement called for R-CFLs that

- Are short enough to fit into recessed downlight fixtures.

- Deliver adequate light with a beam spread that is similar to equivalent wide flood-type incandescent R-lamps.

- Maintain light output levels and life span in a high-temperature environment.

- Are ENERGY STAR compliant.

- Are available at an affordable price. 


\subsection{Overview of this Report}

Chapter 2 of this report describes Phase 1 of the R-CFL technology procurement including preliminary research findings, issuing of the Phase $1 \mathrm{RFP}$, and results of the Phase 1 effort. Chapter 3 describes Phase 2 of the procurement. Chapter 4 describes overall conclusions and findings of the technology procurement effort and how those results have been used in ENERGY STAR criteria and stakeholder (e.g., electric utility and retailer) criteria. Appendix A lists and provides examples of public/consumer information milestones that were met under this program (news releases, fact sheets, lists of published articles...). Appendix B is a draft report providing results of a survey of lighting retailers conducted by PNNL in May 2002. Appendix C provides the RFPs and cover letters and other correspondence with stakeholders related to the technology procurement. Appendix D shows the R-Lamps Savings Calculator. Appendix E describes procedures for safely cleaning up a broken CFL. This report presents the findings, conclusions, and accomplishments of this project and constitutes the conclusion and closeout of this project. 


\subsection{Preliminary Research Findings}

In 2002, before issuing the RFP, PNNL conducted preliminary technical and market research on R-CFLs and identified a number of challenges to increased use of R-CFLs installed in ICAT housings. PNNL's market research included surveying lighting retailers (see Appendix B), interviewing CFL manufacturers and potential large-volume buyers, and working with manufacturers to develop draft minimum technical specifications for the RFP. PNNL issued an RFP for R-CFLs intended for use in ICAT recessed can fixtures in October 2002.

Screw-based CFLs are becoming a popular replacement for Edison-style incandescent lamps. These CFLs work well in many types of fixtures. However, homeowners who have tried installing them in recessed can ceiling fixtures have had less satisfactory results, for two reasons. Typical CFL "bulbs" are not designed to focus their light output in one direction; instead, it radiates out in all directions and much of it is "lost" in the can (see Figure 2.1). While there were some reflector-style CFLs available in 2002 that were specifically designed to direct light out of the fixture, these products were difficult to find and many consumers and retailers didn't know they existed. Existing R-CFL models also suffered from a number of performance problems. Most significantly, CFLs installed in "enclosed" fixtures or ICAT recessed fixtures were subjected to sustained elevated temperatures for which they were not designed. High-temperature operation has three profound negative impacts on CFL performance: reduced light output, reduced lamp life, and color shift. These and other performance issues are described below. The specifications developed for this project addressed light output, lamp life, and other performance issues. Color shift is an individual manufacturer issue.

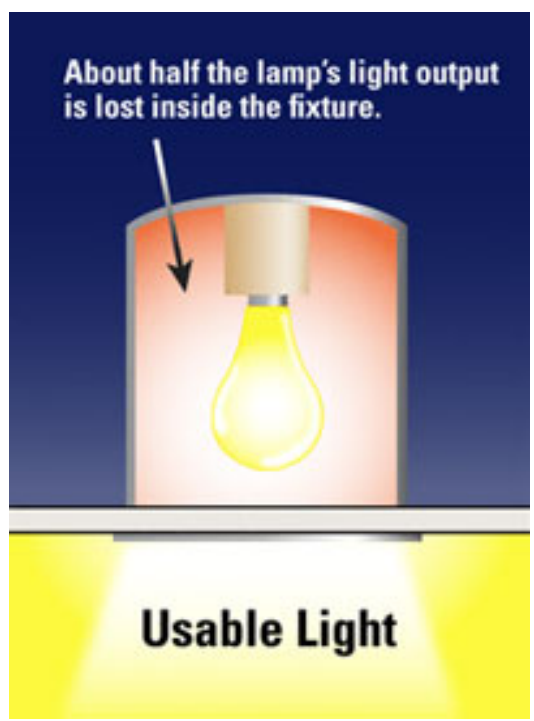

Figure 2.1. When Edison A Lamps or CFLs Are Used in a Recessed Can Fixture 50\% of the Light Emitted by the Lamp Is Lost in the Can

\subsubsection{Reduced Light Output}

CFL light output is partly a function of mercury vapor pressure inside the lamp. Not all of the small amount of mercury in a lamp will become vaporized at any one time. Non-vaporized mercury condenses at the coolest locations ("cold spots") on the lamp and vapor pressure depends upon the temperature of the cold spots. Lamp design, ambient temperature, drafts, etc., all affect the cold spot. A lamp that is too hot 
(or too cold) will see a light output reduction of $10 \%$ to $20 \%$ due to too much or too little mercury being available for the discharge. A rule of thumb for CFL light loss is $1 \%$ for every $1.1^{\circ} \mathrm{C}\left(2^{\circ} \mathrm{F}\right)$ increase in ambient temperature above $38^{\circ} \mathrm{C}\left(100^{\circ} \mathrm{F}\right)$. To combat the problem, some manufacturers add mercury amalgams (an alloy of mercury and other metals). The amalgam stabilizes vapor pressure inside the lamp by absorbing or releasing the available mercury. Lamps with amalgam provide more than $90 \%$ of their rated light output over a wider range of ambient temperature (IESNA 2000). The one negative impact of amalgam technology is that lamps take longer to come up to full brightness, although they still meet the ENERGY STAR ${ }^{\circledR}$ criteria of a maximum three-minute run-up time.

\subsubsection{Reduced Lamp Life}

Typical CFL products were designed to operate at ambient temperatures of approximately $30^{\circ} \mathrm{C}$ to $40^{\circ} \mathrm{C}$ $\left(86^{\circ} \mathrm{F}\right.$ to $\left.104^{\circ} \mathrm{F}\right)$. This not only maximizes the light output but provides the highest efficacy. When temperatures exceed the optimal range, the electrical properties of the lamp change, which in turn causes the ballast to operate outside its design parameters, allowing more than the rated current flow through the lamp. Long-term operation at higher-than-rated current shortens the life of the lamp.

Another cause of high ambient temperature operation (and reduced lamp life) unique to integral (or screw-based) CFLs is the close proximity of ballast components to the heat-generating lamp cathodes. The problem is further exacerbated in ICAT or enclosed applications where ballast components could be exposed to temperatures that approach and/or exceed the temperature ratings of the individual components. The ballast is only as good as its "weakest link" and a single component failure can be catastrophic. CFL manufacturers identified the electrolytic capacitor as the component most susceptible to heat and premature failure. This component, as used in integral CFLs, is typically rated for a maximum operating temperature of $85^{\circ} \mathrm{C}$ or $105^{\circ} \mathrm{C}$ operation.

R-CFL manufacturers typically warranty their products for an ambient temperature of $50^{\circ} \mathrm{C}$ and at least 6,000 hours of rated life (an ENERGY STAR requirement). Figure 2.2 shows the results of 10 R-CFLs tested by PNNL in a simulated ICAT environment in 2002. All but one operated above the manufacturers' maximum operating temperature guidelines.

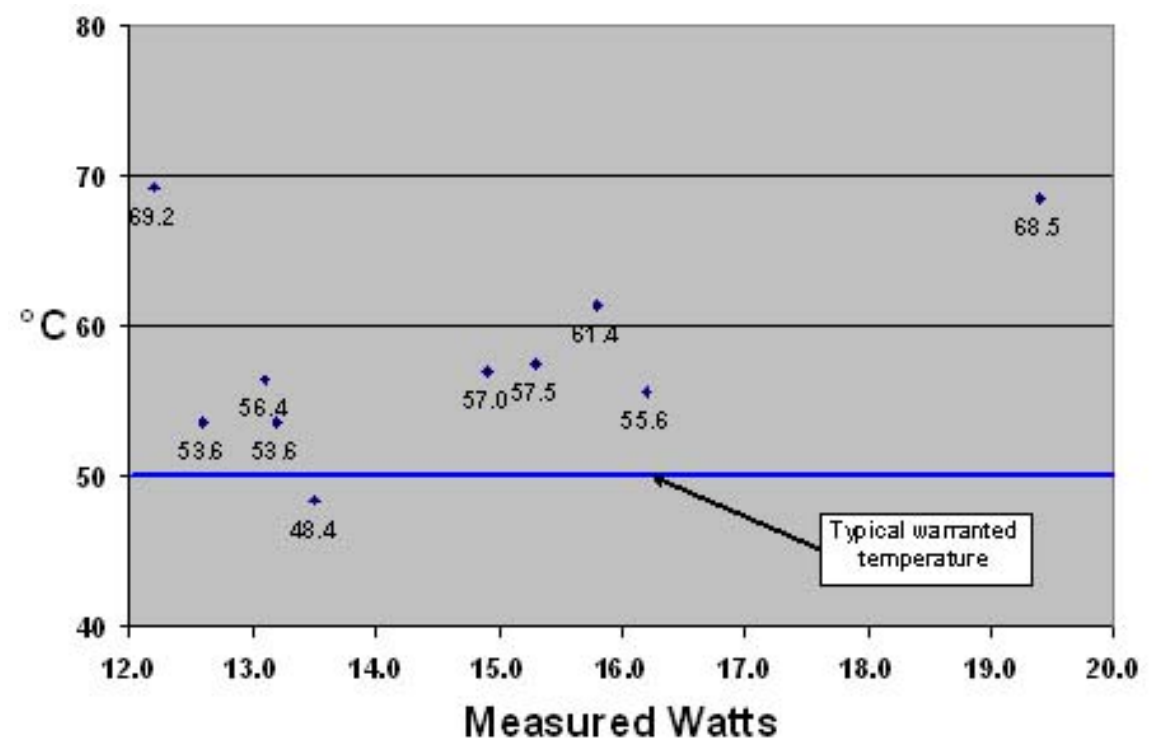

Figure 2.2. Ambient Temperature vs. Watts 


\subsubsection{Color Shift}

The color of light provided by fluorescent lamps is dependent upon the type of phosphor used and the mercury discharge. Each of these factors reacts differently to temperature. High ambient temperature operation tends to shift lamp color toward the blue/green end of the visible spectrum; this shift is noticeable to the naked eye (IESNA 2000).

\subsubsection{High Failure Rates}

While product return data is not widely available, one retailer promoting energy-efficient lighting indicated that the overall returns for R-CFLs were higher than for any other CFL product type, with premature product failure the most prevalent reason for customer returns. The Energy Federation Incorporated (EFI) indicated that the "returns to sales" ratio for R-CFLs was over four times higher than for bare glass CFLs (Steele 2002). Size and fit issues accounted for some reflector returns as well. Return rates were higher for R-40 reflectors than for R-30 reflectors (about 5\% vs. 3\%), which was most likely attributable to a size or fit problem. Thermal-related stress was probably the single most common cause of compact fluorescent lighting product failures for both lamps and fixtures (in pin-based products where the ballast was part of the fixture).

In addition to the limited retailer return data, there was significant anecdotal evidence to indicate performance problems. The Program for the Evaluation and Analysis of Residential Lighting (PEARL) is a watchdog program "created in response to complaints received by utility program managers about the performance of certain ENERGY STAR lighting products being promoted within their service territories and the lack of a self-policing mechanism within the lighting industry that would ensure the reliability of these products and their compliance with ENERGY STAR specifications." PEARL, through its member organizations (utilities, EPA, DOE, market transformation groups, etc.), purchases products available in the marketplace and conducts independent testing to verify compliance with ENERGY STAR requirements. Test results are only provided to PEARL members and individual manufacturers whose products were tested. Test results are not public information; however, there was consensus within the market transformation community that the R-CFL product category had difficulty in a number of areas including, but not limited to, lumen maintenance, life, and efficacy.

\subsubsection{Maximum Overall Length}

We looked at the maximum overall length (MOL) of available R-CFLs and found that few R-CFLs fit into recessed can fixtures designed for incandescent R-lamps when the program started in 2002, although several smaller models are now available. We identified 26 manufacturers and 105 models of 13-watt or greater RCFLs through internet searches, discussions with manufacturers, and visits to manufacturer booths at LightFair 2001. The $13 \mathrm{~W}$ to $26 \mathrm{~W}$ RCFL lamps found at that time ranged in MOL from 5.5 to 7.8 inches long, most were around 6.7 in. For comparison, R30 and R40 incandescent reflector lamps ranged in length from 5.38 to 6.56 inches. Recessed can fixtures typically provide a can length of 6.25 inches.

\subsubsection{Beam Angle}

As stated in the IES handbook, "beam angle is the angle between the two directions for which the intensity is $50 \%$ of the maximum intensity as measured in a plane through the nominal beam centerline" (EPA 2004). The beam angle of R-CFLs was generally much wider than that of incandescent R-lamps. The only category where R-CFLs compared to the beam angle of incandescent R-lamps was the very 
wide flood category. In practice, recessed downlights were often used for ambient lighting in homes, so a wider beam was acceptable or even preferable. R-CFLs were not recommended for narrow-beam or spotlight applications.

\subsubsection{ENERGY STAR® Compliance}

Very few R-CFLs were ENERGY STAR-compliant at the start of this program. Only three manufacturers offered CFL R-lamps that were ENERGY STAR-rated in 2001.

\subsubsection{Availability and Affordability}

Prices for R-CFLs, when you could find them, were high, often upwards of \$15 per lamp at the start of the program. In an informal telephone survey PNNL conducted with 45 retailers including lighting specialty stores, home improvement centers, and hardware stores in May 2002, prices mentioned ranged from $\$ 7.25$ per bulb to $\$ 45$ per bulb. Prices also varied greatly from retailer to retailer. In $2001 \mathrm{PNNL}$ researchers found the same model of Philips RCFL available from three different online retailers for \$20, $\$ 25.95$, and $\$ 32.79$. Prices have come down since 2002. A recent look on-line shows prices hovering around $\$ 8$ to $\$ 10$ for a 15 to $20 \mathrm{~W}$ bulb or $\$ 19.50$ for a 3-pack of $15 \mathrm{~W}$ lamps. However, first-cost remains an impediment to increased market penetration as incandescent reflector lamps can typically be purchased for $\$ 2$ to $\$ 5$ a piece.

\subsubsection{Size of the Market}

The U.S. Census Bureau Current Industrial Report (CIR) program provides monthly, quarterly, and annual measures of industrial activity. These surveys measure manufacturing activity in important commodity areas including electronic components and consumer goods. Unfortunately, the CIR for electric lamps was discontinued in 1994 and obtaining current market data is difficult. However, in 1994 manufacturers reported approximately 130 million reflector incandescent lamps manufactured (U.S. Census Bureau 1995). Given the popularity of these products, it is reasonable to assume that annual production has increased. We estimate there are at least 450 to 500 million recessed lighting fixtures in U.S. homes today, assuming a growth rate of 20 million new R-CFL fixtures a year. California's investor-owned utilities sponsored studies in 2000 and 2005 that analyzed residential lighting. Results of these state-wide studies were indicative of the growing popularity of recessed can fixtures. The study's authors found that recessed cans were the second most prevalent type of fixture in homes (after ceiling fixtures) in 2005 and that the average number of recessed cans per home doubled between 2000 and 2005, going from 2.4 to 4.2 averaged across all home types (including apartments and manufactured homes); $18 \%$ of a home's fixtures were recessed cans in 2005, up from $12 \%$ in 2000 . Also the number of recessed cans per home was much higher for newer homes, averaging 11.2 recessed cans per home for houses built after 1996 compared to 3.9 recessed cans per home for houses built before 1996. The authors also collected data on CFLs and found that the percent of recessed cans with CFLS had increased dramatically from $0.4 \%$ of all recessed cans in 2000 to $10.3 \%$ of recessed cans in 2005 containing R-CFLs (RLW Analytics 2005).

\subsubsection{Potential to Save Energy}

An example of the energy savings that would result from changing a standard 65-watt EPACT incandescent R-lamp to a 16-watt R-CFL with an average rated life of 8,000 hours is provided in Table 2.1. R-CFL lamp prices dropped over the course of the program. When the program began prices averaged around \$15 per R-CFL; as of late 2007 R-CFLs were available for as low as \$5 per lamp. Three 
scenarios are provided below, with all variables remaining the same except for lamp price, which decreases from $\$ 15$ to $\$ 10$ to $\$ 5$ per lamp. In addition to the lighting energy savings, there is also a reduction in the lamp's heat output, which contributes to the space cooling requirements. This example is for a single lamp, operated four hours per day for one year. Most homes have multiple recessed downlights so the savings would be multiplied.

Table 2.1. R-CFLs - Three Lighting Energy Savings Examples Using the R-Lamp Savings Calculator Available on the R-CFL Website www. www.pnl.gov/rlamps

Economic Analysis Inputs: \$15 R-CFL cost

\begin{tabular}{|r|c|l|}
\hline \multicolumn{1}{|c|}{ Inputs } & Values & \multicolumn{1}{|c|}{ Comments } \\
\hline number of bulbs & 1 & \\
\hline R-CFL wattage & 16 & \\
\hline incandescent wattage & 65 & $\begin{array}{l}75 \text { watt incandescent }=20 \text { watt R-CFL } \\
65 \text { watt incandescent }=16 \text { watt R-CFL }\end{array}$ \\
\hline R-CFL cost & $\$ 15.00$ & $\begin{array}{l}\text { \$ per bulb } \\
\text { (insert price) }\end{array}$ \\
\hline incandescent cost & $\$ 3.00$ & $\begin{array}{l}\text { \$ per bulb } \\
\text { (insert price) }\end{array}$ \\
\hline $\begin{array}{r}\text { sub-CFL lifetime } \\
\text { incandescent bulb } \\
\text { lifetime }\end{array}$ & 2,000 & $\begin{array}{l}\text { hours } \\
\text { (rated lifetime for R-CFLs listed on this site: } \\
6000,8000, \text { or 10000) }\end{array}$ \\
\hline electricity cost & 11 cents & $\begin{array}{l}\text { hours } \\
\text { (2000 hours is typical for common incandescent reflector } \\
\text { bulbs) }\end{array}$ \\
\hline Average Electricty Rates \\
For example: average cost is 13.1 cents, enter .131.
\end{tabular}

Results based on R-CFL Cost of \$15:

\begin{tabular}{|l|l|}
\hline R-CFL 5 Year Cost (lamps and electricity) & $\$ 27.60$ \\
\hline Incandescent 5 Year Cost (lamps and electricity) & $\$ 64.20$ \\
\hline R-CFL Cost Savings: & $\$ 36.60$ is a 60\% savings \\
\hline R-CFL Energy Savings & $75 \%$ \\
\hline R-CFL Lifetime (months) & 65.7 \\
\hline
\end{tabular}




\begin{tabular}{|l|l|}
\hline Incandescent Lifetime (months) & 16.4 \\
\hline Average Usage (hours per month) & 121.7 \\
\hline Investment payback will occur in & 18 months \\
\hline
\end{tabular}

If the R-CFL cost is changed to $\$ 10$ and all other values remain the same, the results are:

\begin{tabular}{|l|l|}
\hline R-CFL 5 Year Cost (lamps and electricity) & $\$ 22.60$ \\
\hline Incandescent 5 Year Cost (lamps and electricity) & $\$ 64.20$ \\
\hline R-CFL Cost Savings: & $\$ 41.60$ is a 60\% savings \\
\hline R-CFL Energy Savings & $75 \%$ \\
\hline R-CFL Lifetime (months) & 65.7 \\
\hline Incandescent Lifetime (months) & 16.4 \\
\hline Average Usage (hours per month) & 121.7 \\
\hline Investment payback will occur in & 11 months \\
\hline
\end{tabular}

If the RCFL cost is changed to $\$ 5$ and all other values remain the same, the results are:

\begin{tabular}{|l|l|}
\hline R-CFL 5 Year Cost (lamps and electricity) & $\$ 17.60$ \\
\hline Incandescent 5 Year Cost (lamps and electricity) & $\$ 64.20$ \\
\hline R-CFL Cost Savings: & $\$ 46.60$ is a 70\% savings \\
\hline R-CFL Energy Savings & $75 \%$ \\
\hline R-CFL Lifetime (months) & 65.7 \\
\hline Incandescent Lifetime (months) & 16.4 \\
\hline Average Usage (hours per month) & 121.7 \\
\hline Investment payback will occur in & 4 months \\
\hline
\end{tabular}




\subsection{Phase 1 Request for Proposal Development and Overview}

After several months of industry involvement and feedback on draft minimum technical specifications, on October 25, 2002, PNNL issued a request for proposals for R-CFLs intended for use in ICAT recessed can fixtures. Five manufacturers responded with proposals for 12 R-CFL models. This first RFP and testing of the resulting submittals is referred to as Phase 1. PNNL evaluated each model for compliance with the minimum specifications, including maximum operating temperature, overall lamp length, beam angle, and minimum light output. PNNL also conducted short-term tests (6 hours of operation in a simulated ICAT recessed downlight) to see if the models operated within the manufacturer's rated maximum temperature. Short-term tests verified a number of the manufacturer claims, and long-term elevated temperature testing was initiated on the eight models that met the minimum specifications.

\subsection{Phase 1 ENERGY STAR and Minimum Requirements}

R-CFLs provided by manufacturers in response to PNNL's competitive solicitation (in Appendix C) were evaluated against both the minimum requirements detailed in the technical specifications and successful completion of performance testing. Products first had to be ENERGY STAR certified or be eligible for ENERGY STAR certification and then were required to meet additional criteria aimed at addressing the performance issues identified by PNNL during the preliminary research.

The criteria for ENERGY STAR certification that lamps had to meet in Phase 1 and Phase 2 were the criteria that were approved in 2003 as part of the "ENERGY STAR Program Requirements for CFLs (Final Version 10-30-03). They can be found at http://www.energystar.gov/ia/partners/product_specs/program_reqs/cfls_prog_req.pdf

The minimum requirements added by PNNL are listed in Table 3.1. (This table is excerpted from the Phase 1 RFP and section numbers refer to sections in the RFP.

Lamps that met the minimum requirements were forwarded to an independent testing facility, the Luminaire Testing Laboratory, Inc., located in Allentown, Pennsylvania. The Luminaire Testing Laboratory, Inc. conducted both short-term and long-term laboratory tests. Only models that successfully passed the short-term tests were advanced to the long-term tests. The long-term tests, called Elevated Temperature Life Testing (ETLT), subjected the lights to 6,000 hours or more of operation in a hightemperature environment.

The objectives of the laboratory tests were as follows:

- Determine the "thermal factor" corresponding to the reduction in delivered luminous flux by virtue of operation in the simulated insulated ceiling environment.

- Measure steady state ambient temperatures at a minimum of four elevations within the recessed downlight housing.

- Directly measure electrolytic capacitor(s) temperature(s) at steady state operating conditions.

- Perform elevated temperature life testing on a minimum sample size of 10 units per model. 
Table 3.1. Phase 1 Minimum Requirements for R-CFLs for Insulated Ceiling, Airtight Fixtures

\begin{tabular}{|c|c|c|}
\hline Feature & Minimum Requirement & Verified By \\
\hline $\begin{array}{l}\text { Operating } \\
\text { Temperature } \\
\text { Rating }\end{array}$ & $\begin{array}{l}\text { Maximum Ambient Temperature } \\
\text { rating of at least } 60^{\circ} \mathrm{C} \text {. The offeror } \\
\text { shall provide a maximum ambient } \\
\text { temperature for which the warranty } \\
\text { is valid, and for which the } \\
\text { manufacturer believes the lamp can } \\
\text { reliably operate. }\end{array}$ & $\begin{array}{l}\text { Laboratory tests will be conducted on lamp samples } \\
\text { in a simulated insulated ceiling environment. (See } \\
\text { Section } 4 \text {.) Measured ambient temperatures shall not } \\
\text { exceed the maximum rated ambient temperature for } \\
\text { the products }\left(60^{\circ} \mathrm{C} \text { minimum). }\right.\end{array}$ \\
\hline $\begin{array}{l}\text { Electrolytic } \\
\text { Capacitor(s) Rating }\end{array}$ & $\begin{array}{l}\text { R-lamp electrolytic capacitor(s) } \\
\text { rating of at least } 125^{\circ} \mathrm{C} \text { with a } \\
\text { minimum operating life of } 5,000 \\
\text { hours. }\end{array}$ & $\begin{array}{l}\text { Offeror shall state the type of electrolytic } \\
\text { capacitor(s) used, and its (their) manufacturer- } \\
\text { specified maximum operating temperature, as well as } \\
\text { the manufacturer-specified operating life for the } \\
\text { capacitor at that temperature. } \\
\text { The operational life/mortality curve/Mean Time To } \\
\text { Failure (MTTF) should be specified for the } \\
\text { electrolytic capacitor. } \\
\text { Laboratory tests will be conducted on lamp samples } \\
\text { in a simulated insulated ceiling environment. (See } \\
\text { Section 4) Measured electrolytic capacitor operating } \\
\text { temperatures shall not exceed the maximum rated } \\
\text { operating temperature for the capacitor ( } 125^{\circ} \text { C } \\
\text { minimum). }\end{array}$ \\
\hline $\begin{array}{l}\text { Size Characteristics } \\
\text { R30-type Products } \\
\text { R40-type Products } \\
\text { (BR, PAR, etc. } \\
\text { products also } \\
\text { qualify) } \\
\end{array}$ & $\begin{array}{l}\text { Maximum Overall Length (MOL): } \\
5.6 \text { inches } \\
6.6 \text { inches }\end{array}$ & MOL measured and verified by PNNL. \\
\hline Luminous Flux & $\begin{array}{l}\text { 500 lumens (initial) minimum, } \\
\text { when operated in a simulated } \\
\text { insulated ceiling environment. } \\
\text { When operated at } 60^{\circ} \mathrm{C} \text {, lamp shall } \\
\text { maintain } 90 \% \text { of luminous flux } \\
\text { achieved while operating at } 25^{\circ} \mathrm{C} \text {. }\end{array}$ & $\begin{array}{l}\text { Offeror shall provide IESNA LM-66-2000 Electrical } \\
\text { and Photometric Measurements of Single-Ended } \\
\text { Compact Fluorescent Lamps report with their } \\
\text { submittal. } \\
\text { Laboratory tests will be conducted on lamp samples } \\
\text { in a simulated insulated ceiling environment by } \\
\text { PNNL. (See Section 4.1.) }\end{array}$ \\
\hline Beam Angle & Maximum 120 degrees. & $\begin{array}{l}\text { Offeror shall specify beam angle in proposal. } \\
\text { Photometric testing of beam angle in accordance } \\
\text { with IESNA tests LM- } 20 \text { and LM-9 from an } \\
\text { accredited laboratory shall be provided. }\end{array}$ \\
\hline $\begin{array}{l}\text { Color Rendering } \\
\text { Index }\end{array}$ & 80 or higher & Self certify. \\
\hline $\begin{array}{l}\text { Correlated Color } \\
\text { Temperature }\end{array}$ & $2700-3000 \mathrm{~K}$ & Self certify. \\
\hline \multicolumn{3}{|c|}{$\begin{array}{l}\text { Exception to these Requirements: R-lamp designs that meet the intent of this procurement through } \\
\text { atypical/innovative lamp designs will be considered on an individual basis, provided 1) there is an overriding and } \\
\text { compelling benefit, as described in the Offeror's proposal and 2) the design is approved by the evaluation } \\
\text { committee as being consistent with the overall purposes of this RFP. }\end{array}$} \\
\hline
\end{tabular}




\subsection{Phase 1 Short-Term Laboratory Test Procedure}

The short-term test consisted of operating the R-CFL in a simulated insulated ceiling environment at full power for a minimum of six hours, while taking temperature measurements at several locations.

Manufacturers provided one sample of each model, which was modified by the manufacturer by adding an "access port" to accommodate direct measurement of the electrolytic capacitor(s). Thermocouples were attached to the end of the capacitor via the access port. The short-term test was conducted using a thermal testing apparatus (shown in Figure 3.1) that was equipped as follows:

- Maintains ambient temperature surrounding the apparatus at $25^{\circ} \mathrm{C} \pm 1^{\circ} \mathrm{C}$ $\left(77^{\circ} \mathrm{F} \pm 2^{\circ} \mathrm{F}\right)$.

- Contains loose-fill cellulose insulation to a minimum depth of $12 "$.

- Fitted with an easily removable, tight-closing lid gasketed for air tightness.

- Supports the luminaire at a distance of 36" above the illuminance measurement plane.

- Automatically samples and records ambient temperatures around the lamp for six hours.

- Automatically samples and records the electrolytic capacitor(s) temperature for a minimum duration of six hours.

- Equipped with a photo sensing array consisting of a minimum of five illuminance meters located $36 "$ below the thermal testing apparatus with one meter located directly below the center of the luminaire and the remaining four meters oriented 12 " from the center meter and at $90^{\circ}$ intervals from the center meter.

The short-term test procedure involved a two-step process. The first step was to establish a "pseudobaseline" light output that equated relatively to the manufacturer's rated light output under IESNA LM-66 testing (conducted at $25^{\circ} \mathrm{C} \pm 1^{\circ} \mathrm{C}\left(77^{\circ} \mathrm{F} \pm 2^{\circ} \mathrm{F}\right)$ (IESNA 1991a). The second step was to simulate the insulated ceiling environment by adding insulation. The relative light output measured from pre- and post-insulation conditions determined the thermal factor, expressed as a percentage. The short-term test procedure was as follows:

- Install the lamp in the apparatus within an ICAT recessed downlight housing, such that the end of the lamp intersects the plane of the aperture.

- Apply power to the lamp. Record power readings.

- Allow the system to reach steady-state illuminance.

- Record photometer measurements.

- $\quad$ Remove power from the fixture.

- Immerse the luminaire in 18" (measured from the base of the apparatus) with loose fill cellulose insulation.

- With the lid closed, apply power to the luminaire.

- Begin automatic temperature recording.

- At six hours of operation, record photometer measurements. Record power readings.

- $\quad$ Test completed. 


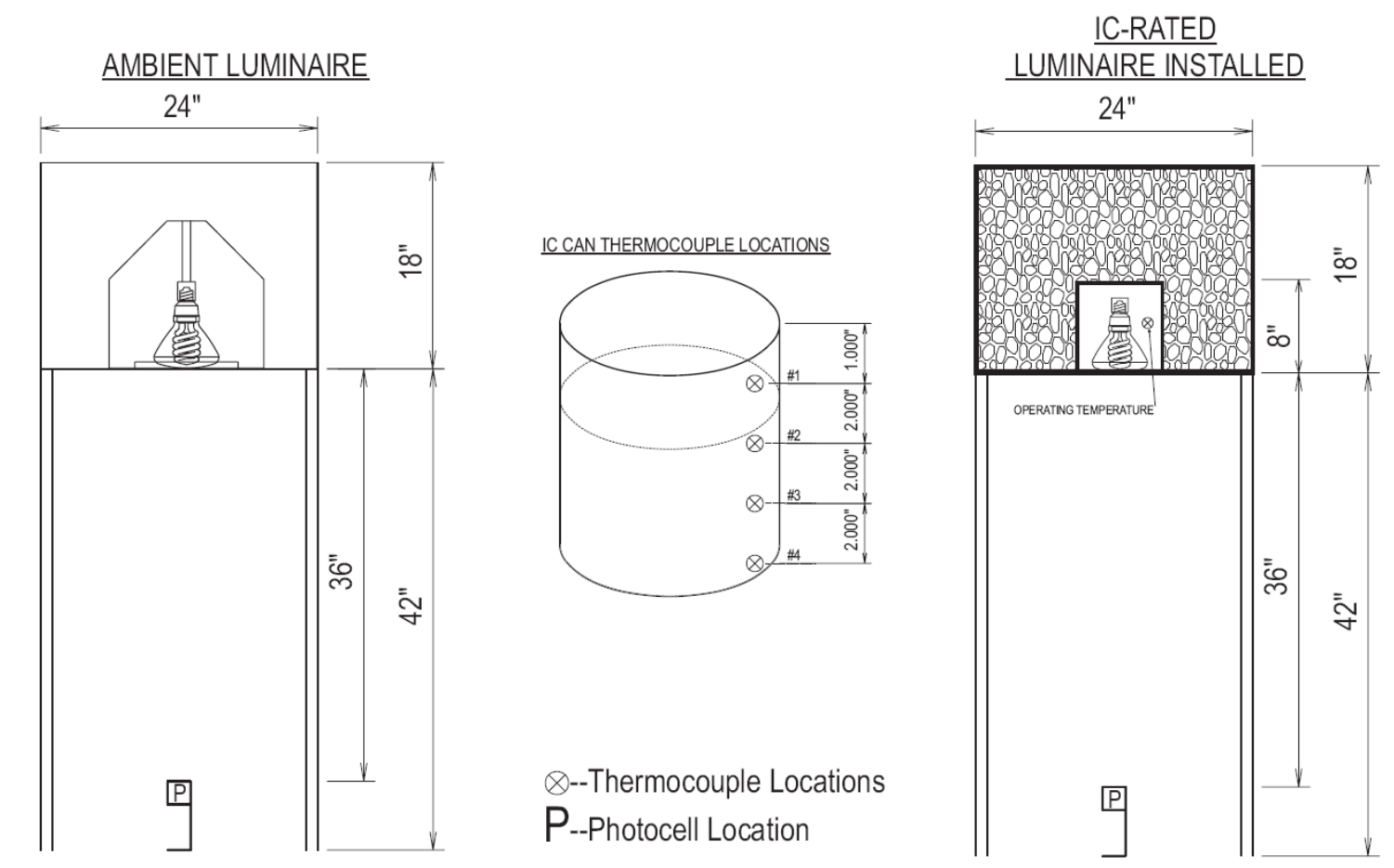

This test was performed using a specific lamp/ballast combination. Extrapolation of these data for other lamp/ballast combinations may produce erroneous results.

Figure 3.1. Short-Term Test Apparatus for Phase 1 and Phase 2 Short-Term Testing Used by Luminaire Testing Laboratory, Inc.

The data collected in the short-term test were used to further evaluate the products against the PNNL performance criteria. The thermal factor was applied to the manufacturer's rated light output (measured at $25^{\circ} \mathrm{C}$ ) to verify that the product met the minimum requirement of 500 delivered lumens in an insulated ceiling environment. The highest recorded ambient lamp temperature was compared to the manufacturer's certified maximum warranted operating temperature. The measured temperature of the electrolytic capacitor(s) was compared to the temperature rating of the capacitor manufacturer.

\subsection{Phase 1 Elevated Temperature Life Testing}

To meet the requirements of the Phase 1 RFP, the R-CFLs were required to have an operating life of at least 6,000 hours at a temperature of $60^{\circ} \mathrm{C}\left(140^{\circ} \mathrm{F}\right)$. To test this, all models that passed the short-term test were subjected to an elevated temperature life test (ETLT) in a special test apparatus that allowed the lamps to be subjected to 6,000 hours of lamp run time on a continuous cycle of 3 hours on and 20 minutes off.

In September 2003, the eight R-CFL models that moved into elevated temperature life testing (ETLT) started a minimum of 6,000 hours of operation in a simulated ICAT environment (laboratory testing); 6,000 hours is a minimum requirement for both this program and ENERGY STAR. Models with rated life claims beyond 6,000 hours were required to continue testing until that claim was met.

Ten lamps of each model were tested. The testing apparatus operated the lamps in an automated cycle of 3 hours on, 20 minutes off, for the test duration. Lamps of 16 watts or less were tested at an ambient temperature of $55^{\circ} \mathrm{C}$, while lamps over 16 watts were tested at $60^{\circ} \mathrm{C}\left(140^{\circ} \mathrm{F}\right)$. DOE measured light 
intensity for each lamp every 2 weeks throughout the long-term testing process to evaluate lumen depreciation over time.

This elevated-temperature life testing procedure is similar to LM-65-91 (IESNA 1991) except that the ambient temperatures are maintained at $60^{\circ} \mathrm{C} \pm 10^{\circ} \mathrm{C}\left(140^{\circ} \mathrm{F} \pm 18^{\circ} \mathrm{F}\right)$, versus the $25^{\circ} \mathrm{C} \pm 10^{\circ} \mathrm{C}\left(77^{\circ} \mathrm{F} \pm 18^{\circ} \mathrm{F}\right)$ prescribed in LM-65-91, to simulate the in-situ environment. Also in the apparatus used by PNNL, 10 models (which consist of 10 samples each) can be tested at the same time.

The elevated-temperature life testing was conducted by the Luminaire Testing Laboratory of Allentown, Pennsylvania, using a testing apparatus developed by LTL with input from PNNL. The apparatus is shown in Figure 3.2 and is built to enable the following:

- Capable of testing a minimum of 100 lamps at one time (10 models of 10 lamps each).

- Maintains ambient temperature in the plane of the lamps at $60^{\circ} \mathrm{C} \pm 10^{\circ} \mathrm{C}$.

- Automatically cycles power to all testing luminaries at a rate of 3 hours "ON" followed by 20 minutes "OFF" for a period of 6000 hours of lamp run-time.

- Automatically senses and records the catastrophic failure of each lamp within a resolution of one hour.

- Automatically records the ambient temperature in the plane of the lamps at a minimum of four locations.

- Prevents radiant heat exposure from adjacent lamps.

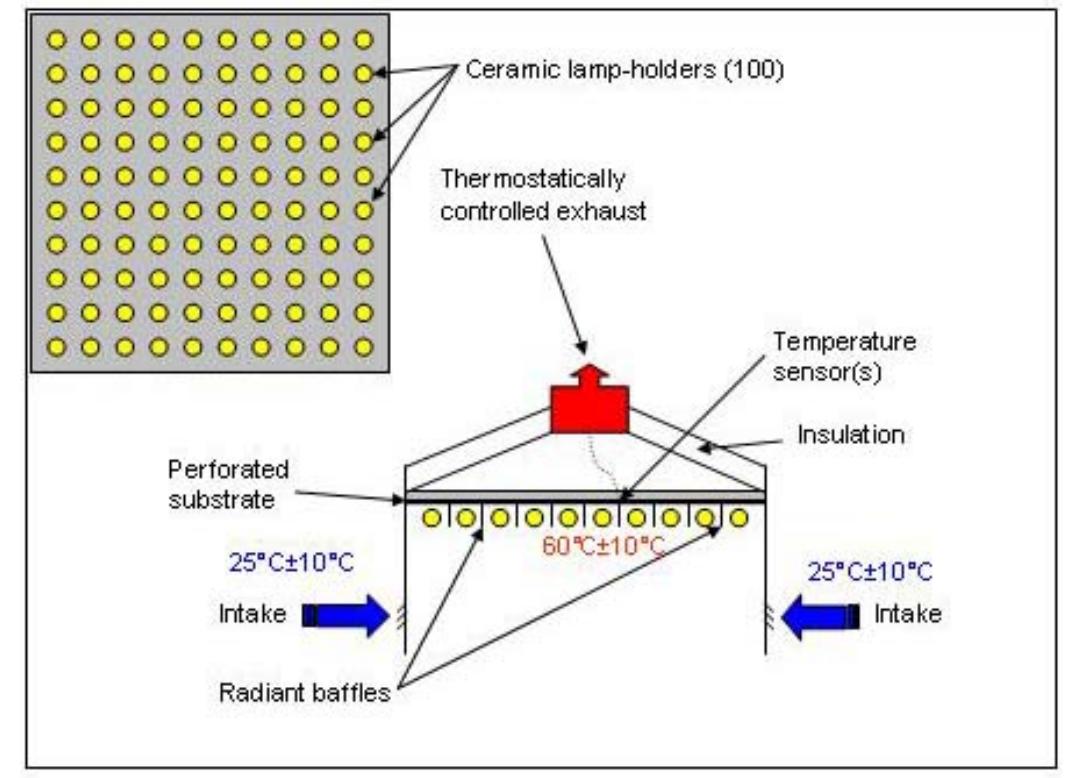

Figure 3.2. Drawing of the Elevated Temperature Life Testing Apparatus

\subsection{Phase 1 Results}

Proposals were received from 5 manufacturers for 11 R-CFL models. Price and technical evaluations of the proposed models were completed, and long-term testing was conducted on the nine models that met the project's minimum requirements. 
Two models reached 6,000 hours of elevated temperature life testing by June 2004 and were announced as winners of the R-CFL technology procurement June 9, 2004, at the Consortium for Energy Efficiency (CEE) meeting in Boston. The two models were the Philips Marathon Flood 20W SLS R40 and the Philips EL/A BR-30. Both lamps continued to be tested under the elevated temperature conditions until they reached 10,000 hours; both lamps have a manufacturer's rated life of 8,000 hours. A third model, the Feit ELS 15R30H, which was a late entry to the long-term testing, completed 6,000 of testing in April 2005 and was also announced as a winner of the procurement. The Feit model continued testing until it reached its manufacturers rated life of 8,000 hours, with none of the 10 tested bulbs failing.

The results for the long-term elevated temperature life testing are shown in Table 3.2.

Table 3.2. Elevated-Temperature Life Testing - Phase 1 Results

\begin{tabular}{|c|c|c|c|}
\hline Manufacturer ID & Model ID & \# Failed (of 10) & Calculated "Rated Life" (hours) \\
\hline A & $4 \mathrm{~A}$ & 10 & 2376 \\
\hline A & $4 \mathrm{~B}$ & 9 & 1075 \\
\hline A & $5 \mathrm{~A}$ & 7 & 3466 \\
\hline B & $8 \mathrm{~A}$ & 8 & 4520 \\
\hline B & $9 \mathrm{~A}$ & 10 & 2595 \\
\hline B & $10 \mathrm{~A}$ & 10 & 2793 \\
\hline Philips & EL/A/BR30 16-W & 3 & $10,000^{(a)}$ \\
\hline Philips & SLS/R40 20-W & 2 & $10,000^{(a)}$ \\
\hline FEIT & ELS 15R30H & 0 & $8,000^{(\mathrm{b})}$ \\
\hline
\end{tabular}

The Philips lamps were made available through The Home Depot Supply Inc. (the commercial subsidiary of The Home Depot) and other channels. In 2005, the third lamp, Feit Model ESL15R30H, was offered through Costco stores nationwide. The Feit lamp was marketed under the brand name "Conserv-Energy" Item \#BPCE15R30H/4. Purchasing information for the winning models was posted to the program website http://www.pnl.gov/rlamps/ordering.stm. The PNNL website did not sell the lamps directly but described them, listed retailers who carried them, and provided a link to the Energy Federation Inc. (EFI) website where they could be purchased. PNNL announced the winning models at trade shows and partner conferences. PNNL also produced a CFL Technology Procurement Phase 1 fact sheet describing the winning models and the benefits of using R-CFL lamps in recessed downlight fixtures. These can be found in Appendix A. A press release announcing the two Philips models was issued July 29, 2004 (see Appendix A).

\subsection{Phase 1 Lessons Learned}

PNNL subcontracted with a ballast expert to conduct a postmortem evaluation on the failed lamps to determine the mode of failure and identify opportunities for improvement. A total of 52 lamps (10 samples each of 8 models) were provided to the expert. Here is a summary of the results:

- Many lamps had one or two “blackened” lamp ends.

- 1 lamp had a small pinhole next to one of the cathodes.

- 11 ballasts had burned resistors.

- 2 ballasts had burned thermistors. 
- 4 ballasts had ruptured capacitors.

- 1 ballast had a burned electrical trace on the circuit board.

- 1 lamp had become disconnected from the ballast. When the lamp was re-connected, the unit operated correctly.

- The electrolytic capacitors showed no discoloration or other visible evidence of damage due to high temperature.

In nearly all cases, the lamp failed first, which in turn damaged the electronic components. Integral CFLs intended for "single use" do not employ the end-of-lamp-life sensing circuitry, which is typically found in remote "hard-wired" ballasts intended for multiple lamp life replacements. The circuitry prevents the ballast from continually attempting to start the lamp; without this circuitry, the lamp cathodes can overheat or cause excessive voltage, leading to damaged components. The information learned from the ballast expert is contrary to the industry-held belief that elevated operating temperatures lead to the premature failure of electronic components (specifically the electrolytic capacitor). However, it must be pointed out that the products tested only represent three manufacturers and a very small portion of currently available products.

Based on these findings, PNNL made the following recommendations:

- Increase the filter capacitor size sufficiently such that Lamp Current Crest Factor (LCCF) will be reduced to 1.7 (a value that is generally accepted by the lamp industry to prevent premature failure of the lamp. Values greater than 1.7 can cause excessive emissive material to be displaced from the lamp cathodes, leading to reduced lamp life).

- Check the high frequency circuit designs so that resonances at the operating high frequency do not produce voltages high enough to destroy components.

- Redesign the circuit so that the ballast will not burn up components at the end of lamp life.

\subsection{Phase 1 Partners}

\subsubsection{Funding Partners}

The following partners supported the program financially:

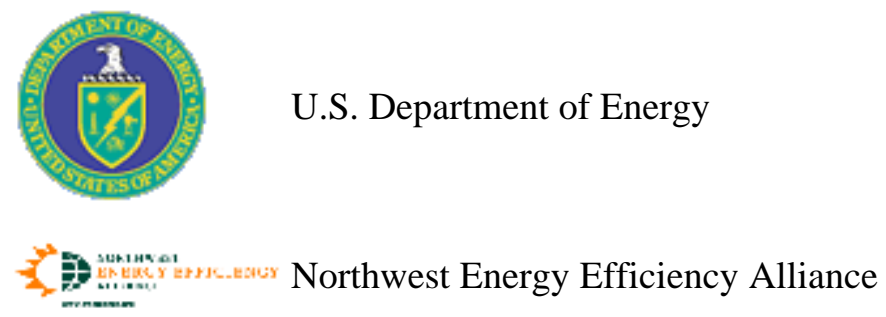

SMUD Sacramento Municipal Utility District 


\subsubsection{Expressions of Interest}

The following partners supported the program through expressions of interest and promotion through their organizations:

CEE

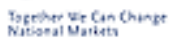

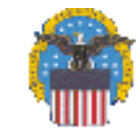

MEEA

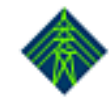

National Grid USA Service Company, Inc.

Natural Resources Defense Council

Northeast Energy Efficiency Partnerships (NEEP) (including NEEP sponsors)

- National Grid (Massachusetts Electric, Granite State Electric, and Narragansett Electric)

- Western Massachusetts Electric/Northeast Utilities (MA)

- Connecticut Lighting and Power/Northeast Utilities (CT)

- $\quad$ NSTAR Electric
- $\quad$ The United Illuminating Company (CT)

- $\quad$ Cape Light Compact

- Unitil/Fitchburg Gas \& Electric

- Efficiency Vermont

- Long Island Power Authority

Snohomish County PUD No. 1

Wisconsin Energy Conservation Corporation

efficiency

MAIN

Efficiency Maine

L

Madison Gas \& Electric 


\subsection{R-CFL Technology Procurement Phase 2}

In late 2004, after reviewing results from the Phase 1 effort, PNNL and DOE decided to conduct a second phase of the R-CFL Technology Procurement to increase the number of qualifying lamps on the market. Only three lamp models by two manufacturers had passed Phase 1, but PNNL felt the lessons learned, especially those regarding causes of early lamp failure, would be helpful to manufacturers in putting forth winning models if a second phase of the procurement were conducted. An RFP for Phase 2, which was called the R-CFL Technology Innovation Competition, was issued on June 3, 2005. Excerpts of the RFP can be found in Appendix C. The primary differences between Phase 1 and Phase 2 were that in Phase 1 manufacturers' products had to meet a price requirement. In Phase 2 the price requirement was dropped because prices on R-CFLs had come down considerably and price was no longer considered a significant obstacle. Some of the technical requirements also differed.

As in Phase 1, R-CFLs submitted in Phase 2 had to meet minimum technical requirements and pass shortand long-term elevated temperature testing. Products first had to be ENERGY STAR certified or be eligible for ENERGY STAR certification and then were required to meet minimum mandatory technical requirements. Lamps that met the minimum requirements were submitted for short-term testing.

\subsection{Phase 2 Minimum Technical Requirements}

Proposed R-CFLs were required to comply with ENERGY STAR® Program Requirements for CFLs, Version 3.0. The specifications are for "single-based compact fluorescent lamps with integral electronic ballasts and which have a reflector that may be open or closed. The lamp will be intended to replace primarily wide beam incandescent reflector lamps." ENERGY STAR CFL specifications can be found at: http://www.energystar.gov/ia/partners/product_specs/program_reqs/cfls_prog_req.pdf. Phase 2 lamps had to comply with the ENERGY STAR CFL specifications approved October 30, 2003. As of October 2007, revised specifications were being reviewed for approval. In addition to the ENERGY STAR requirements, manufacturers had to meet additional minimum criteria that were listed in the RFP and are shown in Table 4.1 below. The manufacturers were asked to self certify or provide evidence (as specified in Table 4.1) that each proposed R-CFL model met or exceeded the technical requirements.

The primary changes from the Phase 1 specifications were as follows: the initial minimum luminous flux was changed from 500 lumens to 600 lumens and the criteria of a minimum $125^{\circ} \mathrm{C}$ temperature rating for the electrolytic capacitors was dropped based on manufacturer feedback and guidance from the ballast expert who evaluated Phase 1 failed products and felt that there were a number of failure factors in addition to the electrolytic capacitor. The primary changes from the Phase 1 specifications were as follows: the initial minimum luminous flux was changed from 500 lumens to 600 lumens and the criteria of a minimum $125^{\circ} \mathrm{C}$ temperature rating for the electrolytic capacitors was dropped based on manufacturer feedback and guidance from the ballast expert who evaluated Phase 1 failed products and felt that there were a number of failure factors in addition to the electrolytic capacitor.

Table 4.1. Phase 2 Minimum Requirements for R-CFLs for Insulated Ceiling, Airtight Fixtures

\begin{tabular}{|l|l|l|}
\hline Feature & Minimum Requirement & Verified By \\
\hline \begin{tabular}{l|l|} 
Operating \\
Temperature Rating
\end{tabular} & $\begin{array}{l}\text { Maximum ambient temperature rating of at } \\
\text { least } 50^{\circ} \mathrm{C} \text { for lamps } 16 \text { watts (measured) } \\
\text { and lower, and } 60^{\circ} \mathrm{C} \text { for lamps greater than }\end{array}$ & $\begin{array}{l}\text { Offeror self-certifies maximum operating } \\
\text { temperature. }\end{array}$ \\
\hline
\end{tabular}




\begin{tabular}{|c|c|c|}
\hline & $\begin{array}{l}16 \text { watts (measured). The Offeror shall } \\
\text { provide a maximum ambient temperature for } \\
\text { which the warranty is valid. }\end{array}$ & \\
\hline $\begin{array}{l}\text { Size Characteristics } \\
\text { R30-type Products } \\
\text { R40-type Products } \\
\text { (BR, PAR, etc. } \\
\text { products also } \\
\text { qualify) }\end{array}$ & $\begin{array}{l}\text { Maximum Overall Length (MOL): } \\
5.6 \text { inches } \\
6.6 \text { inches }\end{array}$ & Offeror self-certifies \\
\hline \multirow[t]{2}{*}{$\begin{array}{l}\text { Rated Luminous } \\
\text { Flux }\end{array}$} & 600 lumens (100 hour) minimum. & $\begin{array}{l}\text { Offeror shall provide IESNA LM-66-00 } \\
\text { Electrical and Photometric Measurements of } \\
\text { Single-Ended Compact Fluorescent Lamps } \\
\text { report with their submittal. ENERGY STAR } \\
\text { currently requires the average of } 5 \text { base-up/5 } \\
\text { base-down. Offeror may meet the } 600 \text { lumen } \\
\text { minimum with either ENERGY STAR or all } \\
\text { base-up configurations. }\end{array}$ \\
\hline & $\begin{array}{l}\text { Elevated temperature luminous flux: When } \\
\text { operated at } 55^{\circ} \mathrm{C} \text {, lamp shall maintain } 90 \% \\
\text { of } 100 \text {-hour luminous flux achieved while } \\
\text { operating at } 25^{\circ} \mathrm{C} \text {. }\end{array}$ & $\begin{array}{l}\text { Laboratory tests will be conducted on lamp } \\
\text { samples in a simulated insulated ceiling } \\
\text { environment by PNNL. (See Section } 4 \text { of the } \\
\text { RFP.) }\end{array}$ \\
\hline Beam Angle & Maximum $120^{\circ}$ & $\begin{array}{l}\text { Offeror shall specify beam angle in proposal. } \\
\text { Photometric testing of beam angle in } \\
\text { accordance with LM-20-94 for fluorescent } \\
\text { lamps shall be provided. }\end{array}$ \\
\hline \multicolumn{3}{|c|}{$\begin{array}{l}\text { Exception to these Requirements: Atypical and innovative R-lamp designs will be considered on an individual } \\
\text { basis, provided, 1) there is an overriding and compelling benefit, as described in the Offeror's proposal and 2) the } \\
\text { design is approved by the evaluation committee as being consistent with the overall purposes and intent of this RFP. }\end{array}$} \\
\hline
\end{tabular}

\subsection{Phase 2 Test Results}

The initial RFP proposal receipt period was scheduled to run from July 18 to August 29, 2005. However, fewer models than expected were received, incomplete proposals were received from some manufacturers, and there were some delays in receiving samples. Because only 15 models were received during this time, a decision was made to extend the deadline to submit models until January 6, 2006. During this extended period, 16 additional models were submitted by two manufacturers. The 15 models initially received were referred to as Batch 1 . The 16 models received later were tested separately and are referred to as Batch 2.

\subsubsection{Batch 1}

Short-term thermal testing was completed in September 2005 on the initial 15 R-CFL models received. Ten of the 15 models passed short-term testing and were submitted to the Luminaire Testing Laboratory for Elevated Temperature Life Testing (ETLT), which was begun on January 4, 2006. The lamps varied in wattage from $15 \mathrm{~W}$ to $26 \mathrm{~W}$. Two were rated for 6,000 hours, ten were rated for 8,000 hours, and three were rated for 10,000 hours. Seven models successfully completed ETLT in Batch 1. The specific ETLT 
results for the 10 lamp models tested in Batch 1 are shown in Table 4.2. The results are shown by model but are averages of the 10 samples of each model that were tested. R-CFL models that moved into ETLT were subjected to a minimum of 6,000 hours of testing to determine their average rated life. Average rated life is defined as the point at which $50 \%$ of the lamps for a particular model in testing have stopped operating.

\subsubsection{Batch 2}

After the decision was made to extend the deadline until January 6, 2006, 16 additional models were submitted by two manufacturers between August 29, 2005, and January 6, 2006. These 16 models each have an average rated life of 8,000 hours and they ranged in wattage from $14 \mathrm{~W}$ to $23 \mathrm{~W}$. Thirteen of these models passed the short-term test and were submitted to long-term testing in Batch 2. ETLT for Batch 2 began in June 2006 and was completed in July 2007. Three models successfully completed ETLT in Batch 2. The specific ETLT results for the 13 lamp models tested in Batch 2 are shown in Table 4.3.

\subsubsection{Overall Results}

A total of 31 models representing four manufacturers were submitted between July 18, 2005, and January 6 , 2006, in response to the request for proposal. All 31 models were moved into short-term testing for thermal evaluation. A total of 23 models progressed to ETLT. Ten of these Phase 2 models passed the ETLT. When these are combined with the Phase 1 winners, 13 models from four manufacturers successfully completed all of the required short-term and long-term testing. The winning models are listed in Table 4.4. Sixteen models are listed because in three instances manufacturers submitted two lamp models that were essentially identical so only one of the models was tested. Those models were as follows:

- Philips Par 3820 W - same as Philips Par 3823 W

- Feit ESL 18 PAR38H $18 \mathrm{~W}$ - same as ESL 18PAR 38H 18W

- Feit BPCE 23R40/3 $23 \mathrm{~W}$ - same as BPCE 23PAR38/3 23W. 
Table 4.2. Phase 2 Batch 1 ETLT Results

\section{Phase 2 Batch 1 Elevated Temperature Life Testing - Lumen Maintenance Final Results} 10/1/07

Average Lumen Maintenance

\begin{tabular}{|c|c|c|c|c|c|c|c|c|c|c|c|c|c|c|c|c|c|c|c|c|c|}
\hline & & \multicolumn{20}{|c|}{ ON" Hrs } \\
\hline Lamp Model & Rated Life $^{2}$ & 0.0 & 151.2 & 302.4 & 453.6 & 604.8 & 756.0 & 907.2 & $1000.0^{1}$ & 1209.6 & 1512.0 & 1814.4 & 1814.4 & 2116.8 & 2419.2 & 2721.6 & 3024.0 & 3326.4 & 3628.8 & 3931.2 & 4233.6 \\
\hline Model 1 & 10000 & $100.0 \%$ & $95.6 \%$ & $92.6 \%$ & $92.3 \%$ & $91.0 \%$ & $90.9 \%$ & $89.5 \%$ & $89.1 \%$ & $88.4 \%$ & $87.1 \%$ & $85.0 \%$ & $85.0 \%$ & $84.7 \%$ & $84.0 \%$ & $83.3 \%$ & $82.0 \%$ & $82.2 \%$ & $81.7 \%$ & $80.5 \%$ & $79.8 \%^{3}$ \\
\hline Model 2 & 8000 & $100.0 \%$ & $99.7 \%$ & $99.0 \%$ & $98.9 \%$ & $98.1 \%$ & $97.5 \%$ & $96.3 \%$ & $95.8 \%$ & $94.6 \%$ & $94.3 \%$ & $92.3 \%$ & $92.3 \%$ & $91.5 \%$ & $90.9 \%$ & $90.4 \%$ & $88.6 \%$ & $88.9 \%$ & $88.2 \%$ & $87.4 \%$ & $86.1 \%$ \\
\hline Model 3 & 6000 & $100.0 \%$ & $98.0 \%$ & $97.6 \%$ & $96.6 \%$ & $94.6 \%$ & $93.5 \%$ & $91.7 \%$ & $91.5 \%$ & $91.0 \%$ & $90.3 \%$ & $86.6 \%$ & $86.6 \%$ & $86.4 \%$ & $85.5 \%$ & $84.8 \%$ & $84.6 \%$ & $85.2 \%$ & $83.9 \%$ & $83.3 \%$ & $81.7 \%$ \\
\hline Model 4 & 8000 & $100.0 \%$ & $95.6 \%$ & $92.0 \%$ & $91.5 \%$ & $89.8 \%$ & $88.2 \%$ & $86.4 \%$ & $85.7 \%$ & $84.2 \%$ & $81.8 \%$ & $79.2 \%$ & $79.2 \%$ & $76.6 \%$ & $76.0 \%$ & $73.9 \%$ & $72.0 \%$ & & & & \\
\hline Model 5 & 10000 & $100.0 \%$ & $97.2 \%$ & $96.0 \%$ & $94.8 \%$ & $92.1 \%$ & $91.3 \%$ & $89.2 \%$ & $89.2 \%$ & $89.2 \%$ & $87.9 \%$ & $83.4 \%$ & $83.4 \%$ & $83.3 \%$ & $82.5 \%$ & $81.1 \%$ & $81.1 \%$ & $81.1 \%$ & $80.0 \%$ & $78.9 \%$ & $77.1 \%$ \\
\hline Model 6 & 8000 & $100.0 \%$ & $95.0 \%$ & $91.6 \%$ & $90.6 \%$ & $88.8 \%$ & $87.6 \%$ & $85.3 \%$ & $85.1 \%$ & $84.7 \%$ & $82.3 \%$ & $78.2 \%$ & $78.2 \%$ & $77.6 \%$ & $76.3 \%$ & $74.8 \%$ & $72.4 \%$ & & & & \\
\hline Model 7 & 10000 & $100.0 \%$ & $95.7 \%$ & $93.2 \%$ & $92.6 \%$ & $91.1 \%$ & $90.5 \%$ & $89.4 \%$ & $88.7 \%$ & $87.0 \%$ & $86.8 \%$ & $85.0 \%$ & $85.0 \%$ & $84.4 \%$ & $84.0 \%$ & $82.9 \%$ & $82.0 \%$ & $82.8 \%$ & $81.6 \%$ & $81.2 \%$ & $80.5 \%$ \\
\hline Model 8 & 8000 & $100.0 \%$ & $98.9 \%$ & $98.6 \%$ & $98.2 \%$ & $97.4 \%$ & $96.9 \%$ & $95.7 \%$ & $95.7 \%$ & $95.7 \%$ & $95.2 \%$ & $92.2 \%$ & $92.2 \%$ & $92.2 \%$ & $91.6 \%$ & $90.5 \%$ & $90.3 \%$ & $90.8 \%$ & $88.5 \%$ & $88.2 \%$ & $87.6 \%$ \\
\hline Model 9 & 8000 & $100.0 \%$ & $94.4 \%$ & $92.0 \%$ & $89.2 \%$ & $87.6 \%$ & $85.9 \%$ & $83.8 \%$ & $83.3 \%$ & $82.2 \%$ & $80.2 \%$ & $75.8 \%$ & $75.8 \%$ & $74.1 \%$ & $73.7 \%$ & $71.8 \%$ & $71.4 \%$ & & & & \\
\hline \multirow[t]{2}{*}{\begin{tabular}{|l} 
Model 10 \\
\end{tabular}} & 6000 & $100.0 \%$ & $93.8 \%$ & $92.2 \%$ & $91.4 \%$ & $89.7 \%$ & $88.9 \%$ & $87.3 \%$ & $87.3 \%$ & $87.3 \%$ & $86.9 \%$ & $82.9 \%$ & $82.9 \%$ & $82.5 \%$ & $83.3 \%$ & $82.6 \%$ & $81.8 \%$ & $81.8 \%$ & $81.0 \%$ & $80.4 \%$ & $79.3 \%$ \\
\hline & \multicolumn{21}{|c|}{ on Hrs" } \\
\hline Lamp Model & 4536.0 & 4838.4 & 5140.8 & 5443.2 & 5745.6 & 6048.0 & 6350.4 & 6652.8 & 6955.2 & 7257.6 & 7560.0 & 7862.4 & 8164.8 & 8467.2 & 8769.6 & 9072.0 & 9374.4 & 9676.8 & 9979.2 & 10281.6 & 10584.0 \\
\hline Model 11 & $78.9 \%$ & $77.7 \%$ & $77.7 \%$ & $77.0 \%$ & $76.3 \%$ & $76.7 \%$ & $77.2 \%$ & $76.3 \%$ & $75.9 \%$ & $77.1 \%$ & $76.9 \%$ & $76.5 \%$ & $77.7 \%$ & $76.9 \%$ & $76.3 \%$ & $76.6 \%$ & $74.8 \%$ & $74.6 \%$ & $70.0 \%$ & $69.7 \%$ & \\
\hline Model 2 & $83.4 \%$ & $79.9 \%$ & $79.9 \%$ & $79.9 \%$ & $79.9 \%$ & $79.9 \%$ & $79.9 \%$ & $79.9 \%$ & $79.9 \%$ & $79.9 \%$ & $79.9 \%$ & & & & & & & & & & \\
\hline Model 3 & $81.1 \%$ & $80.3 \%$ & $80.5 \%$ & $79.9 \%$ & $79.1 \%$ & $78.9 \%$ & & & & & & & & & & & & & & & \\
\hline Model 4 & & & & & & & & & & & & & & & & & & & & & \\
\hline Model 5 & $77.2 \%$ & $76.5 \%$ & $76.3 \%$ & $75.4 \%$ & $74.8 \%$ & $75.9 \%$ & $76.1 \%$ & $75.4 \%$ & $75.4 \%$ & $75.7 \%$ & $76.0 \%$ & $75.1 \%$ & $76.7 \%$ & $76.8 \%$ & $76.1 \%$ & $77.1 \%$ & $74.3 \%$ & $74.0 \%$ & $74.2 \%$ & $73.6 \%$ & \\
\hline Model 6 & & & & & & & & & & & & & & & & & & & & & \\
\hline Model 7 & $79.2 \%$ & $79.1 \%$ & $79.2 \%$ & $78.7 \%$ & $78.2 \%$ & $79.0 \%$ & $78.9 \%$ & $78.4 \%$ & $78.1 \%$ & $78.7 \%$ & $78.6 \%$ & $78.1 \%$ & $79.8 \%$ & $78.5 \%$ & $78.2 \%$ & $78.5 \%$ & $77.0 \%$ & $77.1 \%$ & $76.8 \%$ & $76.9 \%$ & \\
\hline Model 8 & $87.2 \%$ & $86.5 \%$ & $86.2 \%$ & $85.3 \%$ & $84.7 \%$ & $85.6 \%$ & $85.4 \%$ & $84.7 \%$ & $84.5 \%$ & $85.2 \%$ & $85.6 \%$ & $84.8 \%$ & $86.3 \%$ & & & & & & & & \\
\hline Model 9 & & & & & & & & & & & & & & & & & & & & & \\
\hline Model 10 & $79.0 \%$ & $78.3 \%$ & $78.0 \%$ & $77.5 \%$ & $77.2 \%$ & $77.7 \%$ & & & & & & & & & & & & & & & \\
\hline
\end{tabular}

1) 1,000 Hour Lumen Maintenance - ENERGY STAR® requires that average lumen output measurement of the 10 lamps tested must be greater than $90 \%$ of initial (100 hour) lumen output at 1,000 hours (measurement error of $3 \%$ ). Models in red have failed the test.

2) Lamp Mode 10 am

3) $40 \%$ Rated Life Lumen Maintenance - ENERGY STAR $®$ requires that the average of 10 samples tested must be greater than $80 \%$ of initial (100 hour) rating at $40 \%$ of model's rated life (measurement error of $3 \%$ ).

4) Red highigh

5) Readings highlighted in green indicate that the model has successfully completed ETLT. 
Table 4.3. Phase 2 Batch 2 ETLT Results

\section{Phase 2 Batch 2 Elevated Temperature Life Testing - Lumen Maintenance Final Results} 10/1/07

Average Lumen Maintenance

\begin{tabular}{|c|c|c|c|c|c|c|c|c|c|c|c|c|c|c|c|c|c|c|c|c|c|}
\hline \multicolumn{2}{|c|}{ 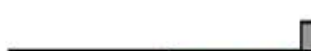 } & \multicolumn{17}{|c|}{ "ON" Hrs } & \multirow{2}{*}{3758.4} & \multirow{2}{*}{\begin{tabular}{|l|}
4060.8 \\
\end{tabular}} & \multirow{2}{*}{4363.2} \\
\hline Lamp Model $^{2}$ & \begin{tabular}{|l} 
Rated Life \\
\end{tabular} & 0.0 & 129.6 & 280.8 & 432.0 & 583.2 & 734.4 & 885.6 & $1000.0^{1}$ & 1036.8 & 1339.2 & 1641.6 & 1944.0 & 2246.4 & 2548.8 & 2851.2 & 3153.6 & $3456.0^{4}$ & & & \\
\hline \begin{tabular}{|l|} 
Model 1 \\
\end{tabular} & 8000 & $100.0 \%$ & $92.7 \%$ & $88.2 \%$ & $87.7 \%$ & $86.7 \%$ & $85.5 \%$ & $84.8 \%$ & $82.7 \%$ & $81.9 \%$ & $78.1 \%$ & $74.8 \%$ & $70.8 \%$ & $67.9 \%$ & $68.1 \%$ & $66.2 \%$ & $64.8 \%$ & $63.4 \%$ & $63.8 \%$ & $63.7 \%$ & $61.3 \%$ \\
\hline Model 2 & 8000 & $100.0 \%$ & $96.3 \%$ & $93.2 \%$ & $92.6 \%$ & $91.3 \%$ & $88.5 \%$ & $88.4 \%$ & $87.1 \%$ & $86.7 \%$ & $85.8 \%$ & $84.8 \%$ & $82.7 \%$ & $81.5 \%$ & $83.2 \%$ & $82.0 \%$ & $80.6 \%$ & $79.5 \%$ & $79.9 \%$ & $80.3 \%$ & $78.3 \%$ \\
\hline \begin{tabular}{|l|} 
Model 3 \\
\end{tabular} & 8000 & $100.0 \%$ & $93.2 \%$ & $88.0 \%$ & $86.9 \%$ & $85.0 \%$ & $83.7 \%$ & $83.4 \%$ & $81.1 \%$ & $80.5 \%$ & $77.7 \%$ & $74.2 \%$ & $70.9 \%$ & $68.7 \%$ & $68.0 \%$ & $66.5 \%$ & $64.3 \%$ & $63.8 \%$ & & & \\
\hline Model 4 & 8000 & $100.0 \%$ & $95.8 \%$ & $92.3 \%$ & $90.4 \%$ & $87.9 \%$ & $86.7 \%$ & $85.8 \%$ & $85.2 \%$ & $85.2 \%$ & $83.4 \%$ & $82.0 \%$ & $79.5 \%$ & $78.2 \%$ & $78.8 \%$ & $78.4 \%$ & $77.4 \%$ & $76.8 \%$ & $77.2 \%$ & $76.9 \%$ & $76.0 \%$ \\
\hline \begin{tabular}{|l|l|l|} 
Model 5 \\
\end{tabular} & 8000 & $100.0 \%$ & $95.3 \%$ & $91.5 \%$ & $89.4 \%$ & $87.0 \%$ & $84.9 \%$ & $84.6 \%$ & $82.8 \%$ & $82.4 \%$ & $80.3 \%$ & $78.8 \%$ & $76.8 \%$ & $76.0 \%$ & $76.3 \%$ & $75.5 \%$ & $74.7 \%$ & $73.5 \%$ & $74.7 \%$ & $74.6 \%$ & $73.7 \%$ \\
\hline \begin{tabular}{|l|} 
Model 6 \\
\end{tabular} & 8000 & $100.0 \%$ & $96.8 \%$ & $93.9 \%$ & $92.7 \%$ & $90.1 \%$ & $89.6 \%$ & $88.7 \%$ & $87.1 \%$ & $86.4 \%$ & $84.9 \%$ & $83.5 \%$ & $82.1 \%$ & $81.1 \%$ & $81.1 \%$ & $80.7 \%$ & $78.5 \%$ & $77.8 \%$ & $78.4 \%$ & $78.5 \%$ & $77.0 \%$ \\
\hline \begin{tabular}{|l|} 
Model 7 \\
\end{tabular} & 8000 & $100.0 \%$ & $95.6 \%$ & $91.5 \%$ & $89.8 \%$ & $88.2 \%$ & $85.8 \%$ & $85.3 \%$ & $84.1 \%$ & $83.7 \%$ & $82.4 \%$ & $81.6 \%$ & $78.5 \%$ & $79.4 \%$ & $79.1 \%$ & $77.7 \%$ & $77.2 \%$ & $76.5 \%$ & $77.5 \%$ & $76.3 \%$ & $75.1 \%$ \\
\hline Model 8 & 8000 & $100.0 \%$ & $93.2 \%$ & $91.7 \%$ & $91.8 \%$ & $90.6 \%$ & $88.8 \%$ & $87.7 \%$ & $86.4 \%$ & $85.9 \%$ & $83.3 \%$ & $81.9 \%$ & $77.2 \%$ & $78.9 \%$ & $78.1 \%$ & $77.2 \%$ & $77.7 \%$ & $74.4 \%$ & $73.0 \%$ & & \\
\hline Model $9^{3}$ & 8000 & $100.0 \%$ & $95.4 \%$ & $91.1 \%$ & $89.7 \%$ & $88.8 \%$ & $86.7 \%$ & $86.9 \%$ & $85.1 \%$ & $84.4 \%$ & $78.8 \%$ & $77.9 \%$ & $75.4 \%$ & $73.5 \%$ & $72.7 \%$ & & & & & & \\
\hline Model 10 & 8000 & $100.0 \%$ & $96.1 \%$ & $92.6 \%$ & $90.5 \%$ & $88.4 \%$ & $86.2 \%$ & $85.7 \%$ & $84.3 \%$ & $83.9 \%$ & $81.2 \%$ & $77.5 \%$ & $77.4 \%$ & $76.6 \%$ & $75.8 \%$ & $75.8 \%$ & $74.4 \%$ & $73.7 \%$ & $74.3 \%$ & $73.6 \%$ & $73.0 \%$ \\
\hline Model 11 & 8000 & $100.0 \%$ & $97.0 \%$ & $93.1 \%$ & $91.6 \%$ & $90.4 \%$ & $88.6 \%$ & $88.8 \%$ & $87.8 \%$ & $87.4 \%$ & $85.8 \%$ & $84.3 \%$ & $82.1 \%$ & $81.0 \%$ & $81.7 \%$ & $79.9 \%$ & $79.1 \%$ & $77.9 \%$ & $77.5 \%$ & $77.9 \%$ & $76.0 \%$ \\
\hline Model 12 & 8000 & $100.0 \%$ & $95.1 \%$ & $90.7 \%$ & $89.1 \%$ & $87.0 \%$ & $85.2 \%$ & $84.7 \%$ & $83.6 \%$ & $83.3 \%$ & $81.1 \%$ & $79.7 \%$ & $77.3 \%$ & $76.2 \%$ & $76.0 \%$ & $75.6 \%$ & $73.1 \%$ & $71.6 \%$ & $72.0 \%$ & $71.1 \%$ & $70.1 \%$ \\
\hline Model 13 & 8000 & $100.0 \%$ & $93.8 \%$ & $90.1 \%$ & $88.2 \%$ & $86.1 \%$ & $84.7 \%$ & $84.1 \%$ & $82.4 \%$ & $81.9 \%$ & $80.0 \%$ & $79.2 \%$ & $76.3 \%$ & $75.6 \%$ & $75.2 \%$ & $73.9 \%$ & $72.6 \%$ & $70.5 \%$ & $71.9 \%$ & $71.6 \%$ & $71.2 \%$ \\
\hline & & & & & & & & & & & & & & & & & & & & & \\
\hline & & & & & & & & & & "ON" HI & & & & & & & & & & & \\
\hline${ }_{\text {Lamp Model }}{ }^{2}$ & Rated Life & 4665.6 & 4968.0 & 5270.4 & 5572.8 & 5875.2 & 6177.6 & 6480.0 & 6782.4 & 7084.8 & 7387.2 & 7689.6 & 7992.0 & 8294.4 & 8596.8 & 8899.2 & 9201.6 & 9504.0 & 9806.4 & \begin{tabular}{|l|}
10108.8 \\
\end{tabular} & 10411.2 \\
\hline \begin{tabular}{|l|} 
Model 1 \\
\end{tabular} & 8000 & $62.3 \%$ & $60.5 \%$ & $57.9 \%$ & $58.1 \%$ & $54.9 \%$ & $50.7 \%$ & & & & & & & & & & & & & & \\
\hline \begin{tabular}{|l|} 
Model 2 \\
\end{tabular} & 8000 & $79.8 \%$ & $77.8 \%$ & $77.8 \%$ & $77.2 \%$ & $75.5 \%$ & $74.7 \%$ & & & & & & & & & & & & & & \\
\hline \begin{tabular}{|l|} 
Model 3 \\
\end{tabular} & 8000 & & & & & & & & & & & & & & & & & & & & \\
\hline Model 4 & 8000 & $77.1 \%$ & $75.0 \%$ & $74.2 \%$ & $74.7 \%$ & $73.3 \%$ & $73.5 \%$ & $73.0 \%$ & $72.6 \%$ & $71.7 \%$ & $70.3 \%$ & $70.6 \%$ & $70.5 \%$ & $70.4 \%$ & & & & & & & \\
\hline Model 5 & 8000 & $74.7 \%$ & $73.9 \%$ & $73.0 \%$ & $73.0 \%$ & $71.2 \%$ & $70.6 \%$ & $70.3 \%$ & $70.4 \%$ & $69.2 \%$ & $68.5 \%$ & $68.0 \%$ & $67.8 \%$ & $67.6 \%$ & & & & & & & \\
\hline \begin{tabular}{|l|} 
Model 6 \\
\end{tabular} & 8000 & $78.8 \%$ & $78.1 \%$ & $77.5 \%$ & $77.8 \%$ & $75.6 \%$ & $75.2 \%$ & & & & & & & & & & & & & & \\
\hline Model 7 & 8000 & $75.3 \%$ & $75.9 \%$ & $74.7 \%$ & $75.0 \%$ & $73.6 \%$ & $73.5 \%$ & $71.9 \%$ & $73.8 \%$ & $72.6 \%$ & $72.4 \%$ & $71.4 \%$ & $71.9 \%$ & $71.1 \%$ & & & & & & & \\
\hline Model 8 & 8000 & & & & & & & & & & & & & & & & & & & & \\
\hline Model 9 ${ }^{3}$ & 8000 & & & & & & & & & & & & & & & & & & & & \\
\hline Model 10 & 8000 & $74.6 \%$ & $73.1 \%$ & $71.9 \%$ & $74.5 \%$ & $71.3 \%$ & $70.5 \%$ & $69.5 \%$ & $71.7 \%$ & $70.1 \%$ & $70.3 \%$ & $71.9 \%$ & & & & & & & & & \\
\hline Model 11 & 8000 & $77.1 \%$ & $76.0 \%$ & $75.7 \%$ & $76.3 \%$ & $73.3 \%$ & $72.6 \%$ & & & & & & & & & & & & & & \\
\hline Model 12 & 8000 & $71.8 \%$ & $71.5 \%$ & $70.8 \%$ & $71.0 \%$ & $67.6 \%$ & $67.5 \%$ & $67.9 \%$ & $67.5 \%$ & $67.1 \%$ & $65.7 \%$ & $65.2 \%$ & $65.3 \%$ & & & & & & & & \\
\hline Model 13 & 8000 & $72.3 \%$ & $72.8 \%$ & $72.4 \%$ & $72.5 \%$ & $69.8 \%$ & $69.5 \%$ & $68.8 \%$ & $68.0 \%$ & $70.2 \%$ & & & & & & & & & & & \\
\hline
\end{tabular}

1) 1,000 Hour Lumen Maintenance - ENERGY STAR@ requires that average lumen output measurement of the 10 lamps tested must be greater than $90 \%$ of initial (100 hour) lumen output at 1,000 hours (measurement error of $3 \%$ Models in red have failed the test.

2) Lamp Model - 10 samples per lamp model undergo testing. Percentage shown in table is the average for the model at a specific number of "on" hours.

3) Readings highlighted ingrey indicate that the model was removed from testing.

4) $40 \%$ Rated Life Lumen Maintenance - ENERGY STAR $\circledast$ requires that the average of 10 samples tested must be greater than $80 \%$ of initial ( 100 hour) rating at $40 \%$ of model's rated life (measurement error of $3 \%$ ).

Readings highlighted in blue indicate the model reached $40 \%$ of rated life. Models in red have failed the test.

5) Readings highlighted ingreen indicate that the model has successfully completed ETLT. 
Table 4.4. R-CFL Technology Innovation Competition Winners

\begin{tabular}{|c|c|c|c|c|c|c|c|c|c|c|c|}
\hline & Model & Lumens & Wattage & $\begin{array}{l}\text { Power } \\
\text { Factor }\end{array}$ & $\begin{array}{c}\text { Rated } \\
\text { Average Life }\end{array}$ & $\begin{array}{l}\text { Color } \\
\text { Temp }\end{array}$ & $\begin{array}{c}\text { Minimum/Operating } \\
\text { Temperature }\end{array}$ & CRI & $\begin{array}{l}\text { Length } \\
\text { (inches) }\end{array}$ & Warranty & Dimming \\
\hline 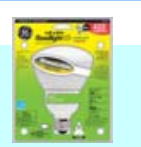 & $\begin{array}{l}\text { GE FLE15/2/DV R30 } \\
15 \text { Watt Dimmable }\end{array}$ & 720 & $15 W$ & 0.6 & 6,000 hours & $2700 K$ & $\begin{array}{l}\text { Minimum Starting } \\
\text { Temperature: } 5^{\circ} \mathrm{F}\end{array}$ & 82 & 5.6 & 4 years & Yes \\
\hline - & $\begin{array}{l}\text { GE FLE15/2/R30XL } \\
15 \text { Watt Reflector Flood }\end{array}$ & 750 & $15 W$ & 0.6 & 10,000 hours & 2700K & $\begin{array}{l}\text { Minimum Starting } \\
\text { Temperature: } 5^{\circ} \mathrm{F}\end{array}$ & 82 & 5.5 & 7 years & No \\
\hline & $\begin{array}{l}\text { Philips EL/A BR30 } \\
16 \text { Watt Reflector Flood }\end{array}$ & 630 & $16 \mathrm{~W}$ & $>0.50$ & 8,000 hours & $2700 K$ & $\begin{array}{l}\text { Operating Range: } \\
-10^{\circ} \text { to } 140^{\circ} \mathrm{F}\end{array}$ & 82 & 5.4 & 7 years & No \\
\hline$\Rightarrow$ & $\begin{array}{l}\text { Feit ESL15R30H } \\
15 \text { Watt Reflector Flood }\end{array}$ & 750 & $15 W$ & 0.638 & 8,000 hours & 2700K & $\begin{array}{l}\text { Minimum Starting } \\
\text { Temperature: }-27^{\circ} \mathrm{F}\end{array}$ & 82 & 5.1 & $\begin{array}{l}2 \text { years res; } \\
1 \text { year com }\end{array}$ & No \\
\hline$\nabla$ & $\begin{array}{l}\text { GE FLE26/2/PAR38/XL } \\
26 \text { Watt Reflector Flood }\end{array}$ & 1300 & $26 W$ & 0.6 & 10,000 hours & $2700 K$ & $\begin{array}{l}\text { Minimum Starting } \\
\text { Temperature: } 5^{\circ} \mathrm{F}\end{array}$ & 82 & 5.6 & 6 years & No \\
\hline (1) & $\begin{array}{l}\text { Philips EL/A PAR38 } \\
20 \text { Watt Reflector Flood }\end{array}$ & 930 & $20 W$ & $>0.55$ & 8,000 hours & $2700 K$ & $\begin{array}{l}\text { Operating Range: } \\
-10^{\circ} \text { to } 140^{\circ} \mathrm{F}\end{array}$ & 82 & 5.67 & 7 years & No \\
\hline$D 2$ & $\begin{array}{l}\text { Philips EL/A PAR38 } \\
23 \text { Watt Reflector Flood }\end{array}$ & 1250 & $23 W$ & & 8,000 hours & $2700 \mathrm{~K}$ & $\begin{array}{l}\text { Operating Range: } \\
-22^{\circ} \text { to } 140^{\circ} \mathrm{F}\end{array}$ & 82 & 5.87 & 7 years & No \\
\hline
\end{tabular}




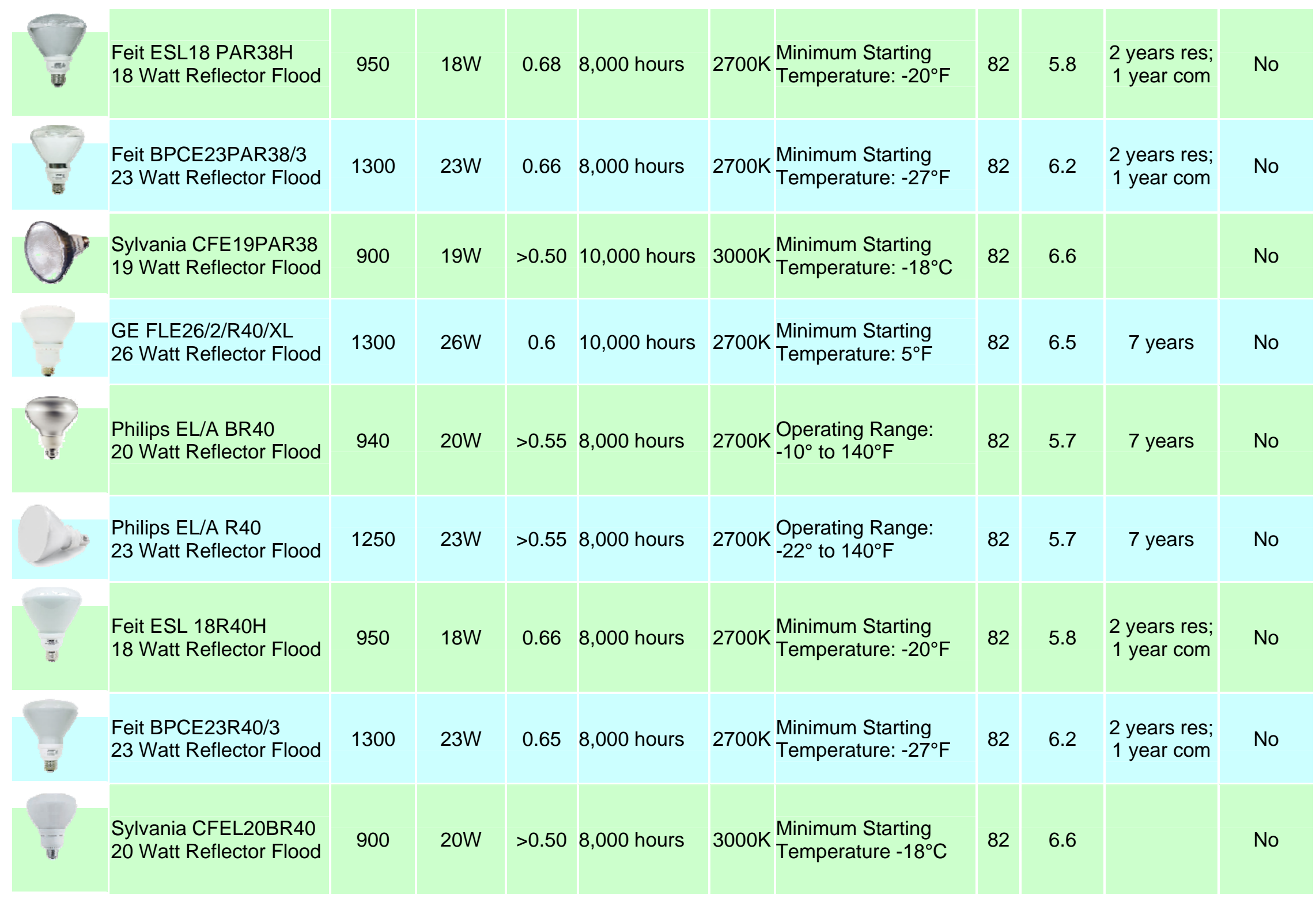




\subsection{Phase $\mathbf{2}$ Technology Innovation Competition Support}

The following organizations provided financial or other support to the R-CFL effort.

Dorthwest Energy Efficiency Alliance, (PDF 46 KB)

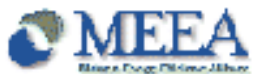

Midwest Energy Efficiency Alliance, (PDF 54 KB)

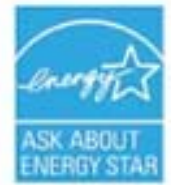

ENERGY STAR Small Business and Congregations, (PDF $120 \mathrm{~KB}$ )

ENERGY STAR Homes, (

CEE

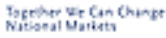

Consortium for Energy Efficiency, Inc., (PDF $150 \mathrm{~KB}$ )

Northeast Energy Efficiency Partnerships (NEEP), (PDF 41 KB)

Participating NEEP Program Sponsors include:

Connecticut

- $\quad$ Northeast Utilities (Connecticut Light and Power)

- United Illuminating Company

Maine

- Efficiency Maine

\section{Massachusetts}

- $\quad$ Cape Light Compact

- National Grid USA (Massachusetts \& Nantucket Electric)

- Northeast Utilities (Western Massachusetts Electric)

- NSTAR Electric

- Unitil

\section{New Hampshire}

- $\quad$ National Grid USA (Granite State Electric)

- Northeast Utilities (Public Service of New Hampshire)

- Unitil 


\section{New Jersey}

- New J ersey Clean Energy Program

\section{New York}

- Long I sland Power Authority

- New York State Energy Research \& Development Authority

- Rhode Island

- National Grid USA (Narragansett Electric)

\section{Vermont}

- Efficiency Vermont

Department of Defense, Defense Logistics Agency, (PDF $130 \mathrm{~KB}$ )

Sacramento Municipal Utility District, ( $\underline{\text { PDF } 681 \mathrm{~KB}}$ )

Snohomish County PUD No. 1, (PDF 8 KB)

EDISON Southern California Edison, (PDF $16 \mathrm{~KB})$

WECC Wisconsin Energy Conservation Corporation, (PDF $117 \mathrm{~KB}$ 


\subsection{Partner Involvement, Outreach, Program Promotion}

As part of its efforts to conduct the R-CFL technology procurement, PNNL engaged in several outreach activities with utilities, regional and national energy-efficiency organizations, lighting retailers, potential volume purchasers, and consumers. Activities conducted as part of Phase 1 and Phase 2 are listed in Appendix A along with copies of fliers and press releases distributed and a list of the articles published about the program. 


\subsection{ENERGY STAR Criteria Development}

In August 2004 PNNL staff met with staff from the DOE ENERGY STAR program, utility and market transformation group staff, and PEARL staff to discuss how to address performance problems associated with the reflector lamp class of ENERGY STAR CFLs. PNNL identified a significant gap in the industry standard test procedures available to evaluate R-CFL lamp performance: traditional lamp ratings,

conducted at ambient temperature of $25^{\circ} \mathrm{C}$, were inadequate to predict the performance of reflector lamps in insulated recessed can fixtures. In response, PNNL worked with an independent testing laboratory to develop an elevated temperature life test (ETLT) to accurately measure R-CFLs. This test procedure was based on existing industry standard test procedures published by the IESNA and accepted test environments defined by UL.

The criteria and the ETLT test apparatus design developed by PNNL have been included by DOE in its ENERGY STAR specifications for the reflector category of CFLs. These specifications were issued in March 2008 and take effect on December 2, 2008. 


\subsection{Conclusions}

The RCFL technology procurement program conducted by PNNL for DOE from 2001 to 2007 helped successfully transform the market by substantially improving the performance and availability of low-cost RCFLs. Major accomplishments of the program are as follows:

- DOE/PNNL identified an important gap in the residential lighting market: a lack of CFLs suitable for the most commonly installed residential fixture type, recessed downlights.

- To work in this application, CFLs would need to be: 1) reflector shaped, to direct light out of the can, and 2) able to withstand high temperatures, always a challenge for electronic components.

- DOE/PNNL crafted technical specifications for this application and invited the lamp industry to meet the specified performance levels.

- PNNL also identified a significant gap in the industry standard test procedures available to evaluate lamp performance: traditional lamp ratings, conducted at ambient temperature of 25C, were inadequate to predict performance of R-CFLs in typical installations such as recessed downlights.

- In response, PNNL worked with an independent testing laboratory to develop an elevated temperature life test (ETLT) to accurately measure the performance of R-CFLs at elevated temperatures. This test procedure was based on existing industry standard test procedures published by IESNA, and accepted test environments defined by UL.

- Outcomes of the first competitive solicitation were disappointing; only three products passed all of the performance tests, while six others failed ETLT after less than half their rated life. DOE and PNNL felt that 3 successful products were not enough to change the market.

- PNNL undertook an in-depth investigation to gain insights into why so many lamps were failing early. Manufacturers pointed to the electrolytic capacitor as the likely culprit, but detailed post-mortem examination of failed lamps found this was not the case. In fact it was not the electronics but the lamps that were failing first. The electronics then overheated and failed as they continued to try to start the failed lamps.

- Resulting from this investigation, PNNL proposed several measures to improve R-CFL performance: limiting the lamp current crest factor, improving high frequency circuit designs to prevent damage from high voltages, and adding end of lamp life circuitry to avoid electronic component failure.

- These technical recommendations were communicated to the lamp industry through presentations, conference calls, and meetings.

- Response to the second solicitation resulted in many more qualifying lamps: 16 models from 4 reputable manufacturers.

- The ETLT procedure was adopted by the ENERGY STAR CFL program for reflector type CFLs.

- Several utility/regional energy efficiency programs and retailers adopted the DOE/PNNL technical specifications and required proof of successful ETLT for R-CFL products.

- Qualifying R-CFLs are now readily available at major retailers, at competitive prices. 


\subsection{References}

IESNA LM-66-00. Electrical and Photometric Measurements of Single-Ended Compact Fluorescent Lamps, Illuminating Engineering Society of North America, Feb 01, 2000.

IESNA. 2000. The IESNA Lighting Handbook, Ninth Edition, MS Rea editor, Illuminating Engineering Society of North America, New York.

IESNA. 1991. "Life Testing of Single-Ended Compact Fluorescent Lamps.” IESNA LM-65-91, Illuminating Engineering Society of North America, New York.

McCullough J. J. and Linda Sandahl, 2004, “Reflector CFLs: Friend or Foe?” Proceedings of the ACEEE 20004 Summer Study. Pacific Northwest National Laboratory, Richland Washington.

RLW Analytics. 2005. 2005 California Statewide Residential Lighting and Appliance Efficiency Saturation Study, Prepared for San Diego Gas and Electric, Southern California Gas Company, Southern California Edison, and Pacific Gas and Electric by RLW Analytics, Sonoma, CA.

Steele, B. 2002. An Examination of the Performance and Acceptance of Compact Fluorescent Bulbs and Fixtures in the Residential Market in Proceedings of the 2002 ACEEE Summer Study on Energy Efficiency in Buildings, Washington DC.

U.S. EPA. 2004. The Integrated Environmental Strategies Handbook: A Resource Guide for Air Quality Planning, US Environmental Protection Agency, Washington D.C. available at http://www.epa.gov/ies/documents/ies_handbook.htm 
Appendix A

Outreach Activities 



\section{Appendix A}

\section{Outreach Activities}

PNNL engaged in several outreach activities to engage the manufacturer and retailer community in the RCFL technology procurement and to promote the winning lamps to retailers, the energy-efficiency community, and consumers. A detailed chronological list of activities for Phase 1 and Phase 2 is provided below. Copies of fliers and fact sheets, press releases, and a list of articles published in the trade press are attached to this appendix.

\section{Phase 1 Activities}

PNNL did several things to promote the Phase 1 procurement and winning lamps. Specific activities are listed below chronologically from October 2001 through March 2005:

- Oct 2001 The draft report Reflector Lamp and Dimmable Compact Fluorescent Lamp Product Procurement Issues was completed and sent to DOE and the Northwest Energy Efficiency Alliance for review.

- Nov 2001 PNNL staff met with NEEA and ECOS staff to discuss the draft report Reflector Lamp and Dimmable Compact Fluorescent Lamp Product Procurement Issues, and draft specifications.

- Nov 2001 PNNL and the Luminaire Testing Lab (LTL) regarding photometric and thermal tests of CFL R-lamps. A contract was put in place with LTL to conduct short-term tests on three CFL R-Lamp models (Sunpark, Maxlite, and Sylvania). Test results will help us prepare minimum specifications for the R-lamp procurement.

- March 2002 Linda Sandahl attended the ACEEE Market Transformation Symposium March 2526 and distributed draft R lamp specifications to industry and utility/MT attendees for comment. A number of utilities stated that they would provide Letters of Support. The updated Technology Fact Sheets was distributed at the meeting. The specifications will be sent to a larger group of manufacturers during the first week of April.

- March 2002, A web site for CFL Reflector Products was developed and placed at http://www.pnl.gov/R-Lamps-rfp/.

- The draft specifications were sent to industry and interested parties for comment on April 8, 2002, with a comment due date of April 29. Comments were received by this date from Sunpark, Osram Sylvania, Feit, Panasonic, Geolight, Angelo Brothers, and General Electric. The comment period was extended to May 20 based on a request to DOE for additional time from the North American Electrical Manufacturers Association (NEMA).

- April 2002 Letters of support for attachment to the RFP have been received from the Defense Logistics Agency, Midwest Energy Efficiency Alliance, Northwest Energy Efficiency Alliance, Natural Resources Defense Council, Wisconsin Energy Conservation Corp., and National Grid (may be part of NEEP letter). We are expecting letters from the ENERGY STAR CFL Program, Lowe's, Snohomish PUD, and the Bonneville Power Administration. Phone calls and emails to possible supporters continued through April. The Consortium for Energy Efficiency (CEE) assisted in this effort by sending the draft specification and a request for support to CEE's Efficiency Lighting Committee. 
- April 2002 We spoke to Richard Karney about the possibility of a letter of support from the ENERGY STAR CFL Program, as well as the eventual adoption of our CFL Reflector Products specification by ENERGY STAR for the Reflector category of CFLs. Richard was receptive to both ideas.

- A letter of support was received from Snohomish PUD. In May 2002 and letters were expected from the ENERGY STAR CFL Program, Lowe's, and the Bonneville Power Administration.

- June 2002 A meeting was held via teleconference among NEMA, NEMA members (representing GE, Philips, and OSRAM), and PNNL staff to discuss NEMA's response to the Reflector CFL draft specifications. Meetings with NEMA continued through Dec 2002.

- June 2002 An email notice was sent to manufacturers informing them that the next version of the draft specifications would be released by July 17 .

- August 2002 A booth with information on the CFL Reflector Products and CFL Recessed Cans Technology Procurements was staffed at the ACEEE Summer Study on Energy Efficiency in Buildings as part of the conference's Technology Showcase.

- Linda Sandahl attended the CEE Members Meeting in St Louis, Missouri on September 9-10, 2002 and provided an update on the CFL Reflector Products, CFL Recessed Can, and CFL Fixtures projects at the Lighting Committee meeting.

- Nov 2002 PNNL issued an RFP to perform long-term and short-term testing on Reflector CFLs; it was sent to lighting test facilities.

- Dec 2002 PNNL received lamps from 5 manufacturers representing 12 lamp models and worked with manufacturers through May 2003 to get complete information on lamps.

- March 2003 Staff met with representatives from 3 of the 5 participating manufacturers attending the National ENERGY STAR Lighting Partner meeting in Tempe, AZ.

- May 2003 Jeff McCullough attended LightFair conference in New York and meet with manufacturers.

- Linda Sandahl attended the CEE meeting in Portland on June 17-18, 2003, and provided attendees with an update on the R-CFL project.

- PNNL Contracts staff sent Teaming Agreements to the three selected manufacturers, outlining the role of PNNL and the manufacturer as products move through the long-term testing phase of the program. PNLL worked with manufacturers over several months to get payment for testing.

- Aug 2003 the website and fact sheets were updated. The fact sheets and website were updated several times over the course of the project and fact sheets were distributed at numerous events and by mail.

- Aug 2003 A status report on the R-CFL project was given to the CEE Lighting Committee in their Sept. meeting in Waltham, MA.

- Feb 2004 PNNL put a contract was put in place with a ballast expert who will evaluate the RCFLs that have failed in long-term testing.

- Prepared a presentation on the R-CFL Technology Procurement and presented it at the ENERGY STAR Partners Meeting in Austin, Texas on April 27, 2004.

- Prepared handouts to distribute at the CEE June 9, 2004, meeting in Boston announcing the winning models. 
- June 2004 Contacted project partners (utilities, market transformation groups, EPA, etc.) to inform them of the winning models and to determine where programs promoting the winning lamp models might occur.

- June 2004 Produced two articles to announce the winning lamp models. The articles were sent with a press packet to selected trade press.

- July 2004 Signed an agreement with The Home Depot Supply to offer the winning lamp models to all its customers via its company web site.

- Created an R-CFL project website, complete with ordering information and test results.

- Aug 2004 Coordinated efforts with the Home Depot Supply, Philips, and the Sacramento Municipal Utility District (SMUD) to help facilitate launch of an effort to deliver the winning lamp models to SMUD area retailers. SMUD, which plans to offer a \$2 rebate specifically on these lamps, continues to work out the details with Philips.

- Aug 2004 Worked with staff from the ENERGY STAR Small Business program to formulate an outreach program for specific small businesses and churches.

- Prepared materials for the Consortium for Energy Efficiency (CEE) partners meeting scheduled for Dallas, Texas in September 2004.

- August 2004 Presented on the R-CFL project to a standing room-only crowd at the ACEEE Summer Study on Energy Efficiency in Buildings.

- Held a number of conference calls with The Home Depot Supply (HDS) regarding promotion of the R-CFLs in their booth at various trade shows, including the National Hotel and Lodging Association conference and trade show scheduled for January 2005 in New York.

- Sept 2004 pursued development of a joint ENERGY STAR/DOE promotion of R-CFLs to ENERGY STAR Small Business partners (i.e., the National Restaurant Association)

- Sept 2004 Staffed a booth at the Northwest ENERGY STAR Lighting Trade Show in Portland, Oregon.

- Prepared the R-CFL Challenge flier to promote the "winning” Phase 1 R-CFLs to ENERGY STAR Small Business and Congregation partners (e.g., the National Restaurant Association); the flier was distributed to seven organizations by ENERGY STAR in December.

- Sept 2004, Philips told us they expected to supply the BR30 16W model in a 2-pack, using an end cap display, to Home Depot stores nationwide in January 2005.

- March 2005 The article "New Reflector CFLs that Can Take the Heat" was published in the March/April 2005 issue of Home Energy magazine and 17 other newspapers, magazines, and trade journals.

\section{Phase 2 Activities}

PNNL did several things to promote the Phase 2 procurement and winning lamps. Specific activities are listed below chronologically from February 2005 through March 2005:

- January 2005 Prepared an R-CFL Technology Procurement flier for Phase 2 
- February 2005 PNNL met with COSTCO to discuss results of Phase 1 and to discuss ways Costco could partner with PNNL in Phase 2.

- Fall 2005, brief articles were drafted on the R-CFL program. An article ran in the Oregonian newspaper.

- Fall 2005 Fact Sheets (Phase 1 and 2) and the website were updated to reflect the most recent information on the winning Feit R-CFLs being sold at Costco.

- Winter 2005 PNNL worked with NEMA and AITL to resolve NEMA questions about PNNL's ETLT test procedure.

- Winter 2005 Builder News requested input for an article they intend to publish on the R-CFL project in April 2006, and we received interest in articles from Home Energy Magazine (update to a previous article) and Light Rays (ALA news).

- April 2006 The article “The U.S. Dept. of Energy (DOE) announced three winners so far in its ongoing research into performance of R-CFLs in high-heat applications” ran in Builder News, April 2006 - http://www.buildernewsmag.com/viewnews.pl?id=356.

- April 2006 Updates were made to the R-CFL Phase 1 and Phase 2 Fact Sheets.

- April 2006 PNNL worked closely with the Luminaire Testing Laboratory staff to automate procedures for reporting test results as ETLT results came in. Results were to be distributed to manufacturers, and the project web site updated with generic (not manufacturer-specific) results periodically.

- May-June 2006 The article "Reflector CFLs Prove They Can Take the Heat" ran in LightRays Newsletter (a publication of the American Lighting Association). The article highlighted the DOE R-CFL project.

- June 2006 Linda Sandahl presented an overview of the R-CFL Technology Innovation Competition at the Consortium for Energy Efficiency Member Meeting in Boston, Massachusetts on June 14, 2006.

- October 2006 An announcement was sent via email to project partners identifying the eight RCFL models that completed 6,000 hours of ETLT in mid October 2006.

- October 2006 PNNL drafted an announcement and article(s) on the "winning” R-CFL models in Phase 2 Batch 1 and shared it with DOE in October 2006. Articles on the R-CFL project were released by lighting.com, EERE Network News (12/15/06), and Edison Electric Institute.

- October 2006 PNNL worked with participating manufacturers to get the product graphics and other materials needed to help populate the R-CFL website

- October 2006 PNNL coordinated with The Luminaire Testing Laboratory, Inc., on reporting of ETLT results. Summary test data was periodically posted to the project web site, and manufacturers were provided with their individual test reports.

- Nov 2006 PNNL staff provided an overview of results via conference call at the NEEP Quarterly Meeting on November 2, 2006.

- Dec 2006 Updates to the R-CFL website continued as manufacturers provided more detail on the winning models. All manufacturers agreed to allow us to post a link to their test data, so those links were added to the website. 
- Feb 2007 A number of articles highlighting the R-CFL project were released: Facilities Management http://www.fmlink.com/Home/News/news.cgi?catid=111\&display=article\&id=22121; HomeLighting.com (see page 4) http://www.homelighting.com/magazine/pdf/126134recessed.pdf; Sustainable Business (included in LED article): http://www.sustainablebusiness.com/features/feature printable.cfm?ID=1402 NEEP Newsletter: http://www.neep.org/newsletter/4Q2006/initiatives.html. Participating manufacturers were sent links to these articles.

- Feb 2007 Two articles on the R-CFL program were published in Feb 2007: "Program Spurs Innovation in Reflector CFLs”, Environmental Building News, February 2007 (page 8), and “Testing Lab Identifies Best Reflector-Type CFLs”, Energy Design Update, February 2007 (page $6)$.

- In Feb 2007, a "quick facts” overview of all winning R-CFL models was added to the website, as well as a number of minor updates.

- Early spring 2007 Three articles on the R-CFL program were published:

o “DOE Announces Winners of R-CFL Competition,” CEE Newsletter, Winter 2007.

o “Reflector-type CFL Lamps can Take the Heat,” NEEA News, March 15, 2007.

o LIPA Offers a Special Daylight Energy Savings Time Promotion.” Mention of \$2.50 per lamp rebate on PNNL-tested High heat reflectors. www.lonislandexchange.com/press/category/press-releases/.

- March 2007 Additional R-CFL models (from Philips and Feit) successfully completed ETLT at the end of March. These models were added (along with test results) to the RCFL web site and an announcement to project partners was released in early April.

- March 2007 Information on R-CFL models that successfully completed ETLT at the end of March, including The Luminaire Testing Laboratory, Inc., test data, product specifications, and graphics was posted on the R-CFL website in April 2007.

- April 2007 An announcement including specifics on the recently-qualified R-CFL models was sent to project partners and other interested parties in early April 2007.

- April 2007 ETLT results reports were provided to manufacturers quarterly and a summary was posted to the website.

- Summer 2007 The website and fact sheets were updated to reflect that all testing has been completed.

- Summer 2007 All Elevated Temperature Life Testing reports were updated. Reports for winning models were updated as needed on the website, as was the overall report.

- Emails with a complete set of test reports were completed for each manufacturer and sent in early October 2007.

- This closeout report was prepared in Oct Nov 2007. 

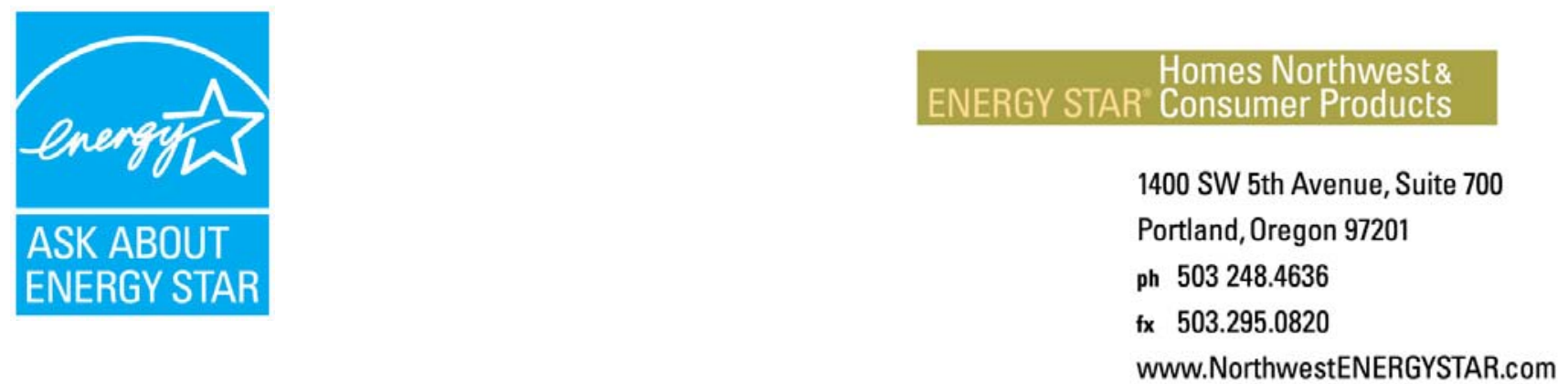

Contact: Bruce Kehe, Maxwell PR, tel: 503.231.3086

For Distribution

Email: Bruce@maxwellpr.com

July 29,2004

\section{Philips Lighting Company R-CFLs Prove They Can Take the Heat}

Two models pass rigorous testing and specification requirements

July 29, 2004 - The Northwest Energy Efficiency Alliance (Alliance) is pleased to announce that two models of reflector compact fluorescent lamps (R-CFLs) manufactured by Philips Lighting Company have met the U.S. Department of Energy's (DOE) stringent performance criteria for its R-CFL project, including ENERGY STAR ${ }^{\circledR}$ certification and a minimum of 6,000 hours of elevated temperature life testing. Both models, the SLS/R40 20 watt and the EL/A BR30 16 watt Reflector Flood, are part of the Philips ${ }^{\circledR}$ Marathon ${ }^{\mathrm{TM}}$ line and available through The Home Depot Supply Inc. (the commercial subsidiary of Home Depot) and other channels. The EL/A BR30 16 watt is new to the market, while SLS SLS/R40 20 watt has been available to consumers for some time.

Recessed can fixtures are a popular lighting choice in many homes and businesses, and almost all of these fixtures use reflector incandescent lamps. Using the screw-based R-CFLs in place of incandescent reflector lamps in recessed can fixtures will cut fixture energy use by up to two-thirds. Generally, recessed cans are installed in insulated ceilings and designed to be airtight to prevent loss of conditioned air into unconditioned spaces above, such as attics. However, airtight (ICAT) cans in an insulated ceiling create harsh operating environments for screw-based CFLs because they trap heat, which can cause them to fail prematurely.

The Alliance and DOE created the R-CFL project to address this issue and encourage manufacturers to develop and bring to market R-CFLs designed for use in these types of fixtures and operating conditions.

"Anywhere between 25 and 40 recessed cans are installed in new homes today," said Alliance Executive Director Margie Gardner. "With up to two-thirds reduction in energy consumption, the opportunity for energy savings with R-CFLs is tremendous. 


\section{R-CFL PROJECT -- 2}

However, the key to transforming the market from incandescent bulbs to R-CFLs in recessed can fixtures is to ensure high product quality - precisely what the R-CFL project was designed to achieve.”

"DOE is proud to be a sponsor of this collaborative effort to encourage the widespread use of R-CFLs specifically designed for use in insulated ceiling rated, airtight downlights," stated David Garman, Assistant Secretary for Energy Efficiency and Renewable Energy at DOE. "These lamp models have successfully demonstrated their durability and performance, and they offer consumers and businesses alike substantial energy savings over conventional incandescent lamps.”

Commercial buildings, such as restaurants, hotels and multifamily housing facilities, are also often equipped with recessed can fixtures. Apartment buildings and hotels, for example, often use recessed cans in common areas, many of which remain lit for extended hours. Energy use in these applications could be reduced significantly by using R-CFLs rather than incandescent reflectors.

While the project focused on developing R-CFLs for ICAT cans, the Philips models selected will perform equally well in non-ICAT cans, tracks or even wallmounted floods. ICAT cans are generally required on the uppermost floor of a building with gypsum wall board ceilings in contact with insulation, so they are more commonly found in residential versus commercial buildings. R-CFLs are not recommended for spotlight applications where a narrow, directed beam is required.

Since 2001, demand for CFLs has surged. Due to their significant energy-savings potential, CFLs are popular with energy-efficiency groups and electric utilities that frequently offer their customers incentives to convert to lamps that consume less energy. In 2003, these programs totaled over \$43 million in incentives and advertising and serve more than 60 million customers. CFL sales in the Northwest alone are projected by the Alliance to increase by 750,000 to 1 million annually from the 2003 level of 3.8 million lamps sold, reaching total sales of 9 million per year by 2010 .

\section{About the DOE/Alliance R-CFL Project}

DOE's Pacific Northwest National Laboratory (PNNL) received proposals from five manufacturers representing 12 R-CFL models in response to its November 2002 Request for Proposals (RFP). PNNL completed technical evaluations of all of the lamps to make sure they met rigorous program requirements for light output, size, beam angle and operating temperature. Furthermore, the lamps had to meet ENERGY STAR specifications. The lamps also had to undergo short- and long-term testing in a simulated insulated ceiling environment to test whether they would continue operating correctly for their rated lifetime. The two Philips models, SLS/R40 and the EL/A BR30 Reflector Flood, were the only lamps to pass all of the tests. 


\section{R-CFL PROJECT -- 3}

DOE plans to continue the project to test and identify more R-CFLs suitable for use in ICAT recessed cans. To order the winning Philips lamps, contact The Home Depot Supply Inc. at 800-431-3000. For more information on the R-CFL project, visit www.pnl.gov/R-Lamps.

\section{About ENERGY STAR and the Northwest Energy Efficiency Alliance}

ENERGY STAR was introduced by the U.S. Environmental Protection Agency in 1992 as a voluntary labeling program designed to identify and promote energy-efficient products in order to reduce greenhouse gas emissions. Today, the ENERGY STAR program is a joint partnership between EPA and Department of Energy and delivers the technical information and tools that organizations and consumers need to choose energyefficient products and services. For a complete list of ENERGY STAR qualified products, retailers, manufacturers and energy savings information, call 1-888-373-2283 or log onto: www.energystar.gov.

The R-CFL project is supported by the Northwest Energy Efficiency Alliance, a non-profit corporation supported by electric utilities, public benefits administrators, state governments, public interest groups and energy efficiency industry representatives. These entities work together to make affordable, energy-efficient products and services available in the marketplace. For more information about the Northwest Energy Efficiency Alliance, please visit their website at www.nwalliance.org. 
Table A.1. List of Articles Published about the R-CFL Technology Procurement

\begin{tabular}{|c|c|c|c|}
\hline Publication & Appeared & Web Address & Article Title \\
\hline \multicolumn{4}{|l|}{2007} \\
\hline Long Island Exchange & March 15, 2007 & $\begin{array}{l}\text { www.longislandexchange.com/press/category } \\
\text { /press-releases/ }\end{array}$ & $?$ \\
\hline $\begin{array}{l}\text { Environmental Building } \\
\text { News }\end{array}$ & Feb. 2007 & & Program Spurs Innovation in Reflector CFLs \\
\hline Energy Design Update & Feb. 2007 & www.aspenpublishers.com & Testing Lab Identifies Best Reflector-Type CFLs \\
\hline $\begin{array}{l}\text { Facilities Management } \\
\text { News } \\
\text { CEE Newsletter } \\
\text { (Consortium for Energy } \\
\text { Efficiency) } \\
\end{array}$ & $\begin{array}{l}\text { Jan. 8, } 2007 \\
\text { Winter } 2007\end{array}$ & $\begin{array}{l}\text { http://www.fmlink.com/News/Articles/news.cgi } \\
\text { ?catid=111\&display=article\&id=22121 } \\
\text { http://www.cee1.org/resrc/news/07- } \\
\text { 02nl/11E_r-cfl.html }\end{array}$ & $\begin{array}{l}\text { DOE Announces R-CFL Lighting Competition Winners } \\
\text { DOE Announces Winners of Reflector-CFL } \\
\text { Competition }\end{array}$ \\
\hline $\begin{array}{l}\text { Home Lighting \& } \\
\text { Accessories }\end{array}$ & January '07 & $\begin{array}{l}\text { http://www.homelighting.com/magazine/pdf/12 } \\
\text { 6-134recessed.pdf }\end{array}$ & Lighting that's (not quite) out of sight \\
\hline New York Times & Jan. 3, 2007 & $\begin{array}{l}\text { http://www.nytimes.com/2007/01/03/opinion/0 } \\
\text { 3wed3.html?th\&emc=th }\end{array}$ & A light bulb goes on \\
\hline New York Times & Jan. 2, 2007 & $\begin{array}{l}\text { http://www.nytimes.com/2007/01/02/business/ } \\
\text { 02bulb.html?_r=2\&oref=slogin\&oref=slogin }\end{array}$ & $\begin{array}{l}\text { Wal-Mart Puts Some Muscle Behind Power-Sipping } \\
\text { Bulbs }\end{array}$ \\
\hline \multicolumn{4}{|l|}{2006} \\
\hline Blachy-Lane Coop & Dec. 5,2006 & $\begin{array}{l}\text { http://www.blachlylane.coop/news/story.php?I } \\
D=218\end{array}$ & Reflector-Type CFL Lamps Can Take the Heat \\
\hline Sustainable Business.com & Dec. 20, 2006 & $\begin{array}{l}\text { http://www.sustainablebusiness.com/features/ } \\
\text { feature_printable.cfm?ID=1402 }\end{array}$ & $\begin{array}{l}\text { DOE Study Finds Commercial LED Lamps Fall Short } \\
\text { of Claims }\end{array}$ \\
\hline Lighting.com & Dec. 19,2006 & $\begin{array}{l}\text { http://www.lighting.com/content.cfm?id=2653\& } \\
\text { page=/ }\end{array}$ & $\begin{array}{l}\text { DOE Announces Winners of Reflector-CFL } \\
\text { Competition }\end{array}$ \\
\hline \begin{tabular}{|l|} 
NEEP Notes (Northwest \\
Energy Efficiency \\
Partnerships) \\
\end{tabular} & $\begin{array}{l}\text { 4th quarter } \\
2006\end{array}$ & $\begin{array}{l}\text { http://www.neep.org/newsletter/4Q2006/initiati } \\
\text { ves.html }\end{array}$ & Energy Star Lighting \\
\hline $\begin{array}{l}\text { NEEA Alliance News } \\
\text { (Northwest Energy } \\
\text { Efficiency Alliance) }\end{array}$ & Nov. 29, 2006 & $\begin{array}{l}\text { http://www.nwalliance.org/news_media/newsl } \\
\text { etter/nl_13.asp }\end{array}$ & Reflector-Type CFL Lamps Can Take the Heat \\
\hline
\end{tabular}




\begin{tabular}{|c|c|c|c|}
\hline $\begin{array}{l}\text { American Lighting Assn. } \\
\text { Lightrays newsletter }\end{array}$ & May 25, 2006 & $\begin{array}{l}\text { http://www.americanlightingassoc.com/memb } \\
\text { ers/files/05_06Lightrays.pdf }\end{array}$ & Reflector CFLs Prove they can take the heat \\
\hline Lighting.com & May 3, 2006 & & \\
\hline BUILDERnews Magazine & April 9, 2006 & & \\
\hline IESNA Industry News & April 17, 2006 & & \\
\hline The Oregonian & $\begin{array}{l}\text { January 26, } \\
2006\end{array}$ & & Can-DO Lighting \\
\hline \multicolumn{4}{|l|}{2005} \\
\hline BPA Journal & Aug.1, 2005 & www.bpa.gov/corporate/pubs/Journal & Savings with a Twist \\
\hline Energy Vortex & April 21, 2005 & $\begin{array}{l}\text { http://www.energyvortex.com/pages/headlined } \\
\text { etails.cfm?id=1519 }\end{array}$ & $\begin{array}{l}\text { New Reflector Compact Fluorescent Lamps Prove } \\
\text { They can take the Heat }\end{array}$ \\
\hline FN FinanzNachrichten & April 1, 2005 & $\begin{array}{l}\text { http://www.finanznachrichten.de/nachrichten- } \\
\text { 2004-12/artikel -4192652.asp }\end{array}$ & $\begin{array}{l}\text { Philips Lighting Company Reminds Consumers of } \\
\text { Simple Guidelines for Purchasing Safe, Energy- } \\
\text { Saving Compact Fluorescent Lamps (CFLs) }\end{array}$ \\
\hline $\begin{array}{l}\text { Environmental Design \& } \\
\text { Construction }\end{array}$ & April 1, 2005 & $\begin{array}{l}\text { http://www.edcmag.com/CDA/Articlelnformati } \\
\text { on/products/BNPProductltem/0,4125,148097, } \\
\text { o0.html }\end{array}$ & Compact Fluorescent Lamps \\
\hline Home Energy Magazine & $\begin{array}{l}\text { March/April } \\
2005\end{array}$ & www.homeenergy.org & New Reflector CFLs that can take the heat \\
\hline \multicolumn{4}{|l|}{2004} \\
\hline Popular Mechanics & June 1, 2004 & $\begin{array}{l}\text { http://www.popularmechanics.com/home_jour } \\
\text { nal/home_improvement/1275086.html }\end{array}$ & The Bright Stuff: Brighter, better light bulbs \\
\hline \multicolumn{4}{|l|}{ OTHER Publications } \\
\hline $\begin{array}{l}\text { EFI (Energy Federation } \\
\text { Incorporated) }\end{array}$ & $\begin{array}{l}\text { Web page to } \\
\text { purchase } \\
\text { products }\end{array}$ & $\begin{array}{l}\text { http://www.energyfederation.org/consumer/def } \\
\text { ault.php/cPath/2106_2107 }\end{array}$ & DOE Competition Reflectors \\
\hline
\end{tabular}




\section{Technology Procurement:}

\section{A Method for Speeding Technology Introduction}

\section{Background}

The U.S. Department of Energy (DOE) and Pacific Northwest National Laboratory (PNNL) are using an innovative approach to speed the market introduction of new, energy-efficient products. This approach, known as Technology Procurement, has been applied successfully to bring new refrigerators, subcompact fluorescent lamps, and other efficient products to market in recent years. DOE and PNNL are now using this approach for a number of new product categories.

\section{What is Technology Procurement?}

Technology procurement is a method to "pull" new technologies and products into the marketplace through competitive procurements backed by large-volume buyers. In general, the sponsors of technology procurements undertake the following steps:

- Organize selected large volume buyers and market influencers (such as utilities);

- Interact with buyers to understand their business and technology needs in detail;

- Develop technical specifications in consultation with both buyers and manufacturers of the technology;
- Issue a competitive solicitation to potential manufacturers/ suppliers, requesting their bids to provide new products meeting the specifications; and

- Select one or more winners from those bids, then implement marketing and consumer education programs to maximize the purchase of the newly available products.

By working closely with potential buyers, technology procurement greatly increases the likelihood that products brought to market will be well received by buyers. And by organizing large volume buyers for new products, technology procurement reduces the risks to manufacturers of new product introduction, and allows them to introduce products at more competitive prices.

Various forms of technology procurement have been used by DOE and other organizations, including the following examples:

- Energy-Efficient Window Procurement Swedish National Energy Administration

- Apartment Size Refrigerator Program - New York Power Authority (NYPA), Consortium for Energy Efficiency (CEE), DOE

- Super Efficient Refrigerator Program (SERP) - CEE

- Copier Procurement EPA, DOE, International Energy Agency

\section{A Strong Energy Portfolio for a Strong America}

Energy efficiency and clean, renewable

energy will mean a stronger economy,

a cleaner environment, and greater energy

independence for America. Working with

a wide array of state, community, industry,

and university partners, the U.S. Department

of Energy's Office of Energy Efficiency and

Renewable Energy invests in a diverse

portfolio of energy technologies.

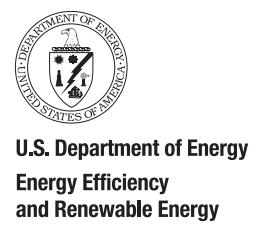




\section{Residential Recessed Downlights}

DOE and PNNL, in cooperation with utilities and energy efficiency organizations nationwide, are managing a program to introduce new energy-efficient, residential recessed downlight fixtures into the market. The procurement sought airtight fixtures that are rated for use in insulated ceilings and hard-wired for compact fluorescent lamps.

Residential recessed cans have been identified as an energyintensive product in need of design improvements. Efficient recessed cans could cut energy consumption by approximately two-thirds.

For more information on the status of the Recessed Downlight Technology Procurement, contact Jeff McCullough, PNNL at (509) 375-6317 or jeff.mccullough@pnl.gov. Website: www.pnl.gov/cfldownlights.

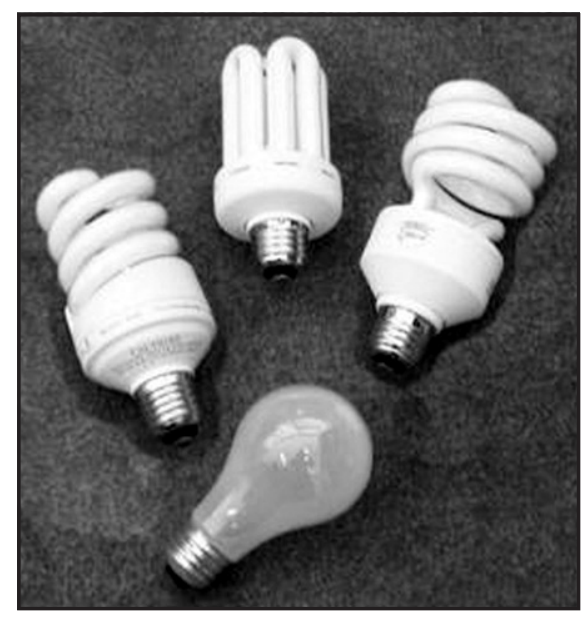

\section{Subcompact Fluorescent Lamps (Sub-CFLs)}

This technology procurement was designed to encourage the introduction of high-performance compact fluorescent lamps (CFLs) that were smaller, better performing, and less expensive than those available in the market. The competitive solicitation set aggressive size and performance specifications. As a result, 17 new sub-CFLs were introduced to the market between May 1998 and April 2000. Total sales exceeded 3.3 million lamps by the program's conclusion in August 2001.
For Program Information on the Web: http://www.buildings.gov For Program and Product Information
on the Web:

www.eren.doe.gov/buildings/emergingtech

\section{For Program Information:}

Marc Ledbetter

Pacific Northwest National Laboratory

Phone: (503) 417-7557

Email: marc.ledbetter@pnl.gov

For more information on the Sub-CFL Technology Procurement, contact

Linda Sandahl, PNNL at (503) 417-7554 or linda.sandahl@pnl.gov.

\section{Unitary Rooftop Air Conditioners}

DOE (including the Federal Energy Management Program), PNNL, and the Defense Logistics Agency (DLA) are engaged in a program to promote the introduction of highly efficient commercial rooftop air conditioners for federal and private buyers.

Product features include higher overall efficiency, with an energy efficiency rating (EER) of 13 or better, lower energy consumption over the range of temperatures encountered in typical applications, improved humidity control, and lower initial cost compared to other high-efficiency units.

For more information on the status of the Unitary Air Conditioner Technology Procurement, contact Brad Hollomon, PNNL at (202) 646-5043 or hollomon@pnl.gov. Website: www.pnl.gov/uac.

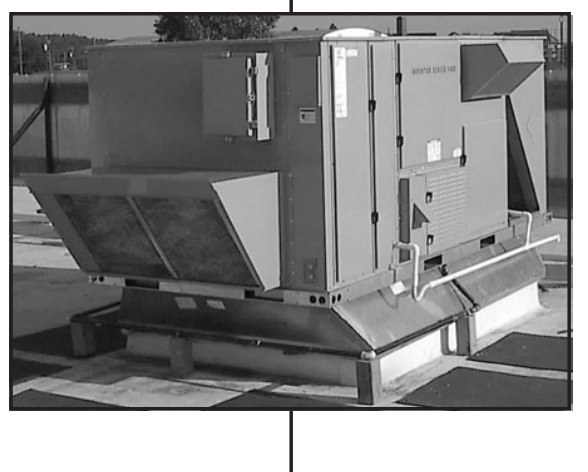

PNNL-SA-40225

November 2003

Printed with soy ink on recycled paper 


\section{R-CFL Technology Procurement}

\section{Overview}

Recessed downlights are among today's most popular lighting fixtures with an estimated 350 million installed in U.S. homes. The vast majority of these fixtures are fitted with incandescent reflector lamps (R-lamps) typically drawing 65 to 100 watts of power per lamp. An estimated 120 to 140 million R-lamps are sold in the United States each year. Roughly half of these are for residential use.

Many incandescent R-lamps could be replaced with reflector compact fluorescent lamps (R-CFLs) that produce similar light levels while using as little as $1 / 3$ the energy. While energy efficiency advocates have embraced CFLs, there have been concerns about the performance and longevity of R-CFLs when used in recessed downlight fixtures installed in insulated ceilings with airtight housings (ICAT). Operating temperatures increase dramatically, which directly impacts light output and can reduce lamp life, when R-CFLs are installed in cans versus open fixtures.

\section{Program \\ Sponsors}

This effort, sponsored by the U.S. Department of Energy (DOE) and the Northwest Energy Efficiency Alliance (Alliance), and implemented by the Pacific Northwest National Laboratory (PNNL), aims to improve the performance of R-CFLs and increase their availability in the Northwest and throughout the United States by means of a technology development and procurement strategy. Technology procurement is a method for pulling new technologies and products into the marketplace through competitive procurements backed by large-volume buyers.

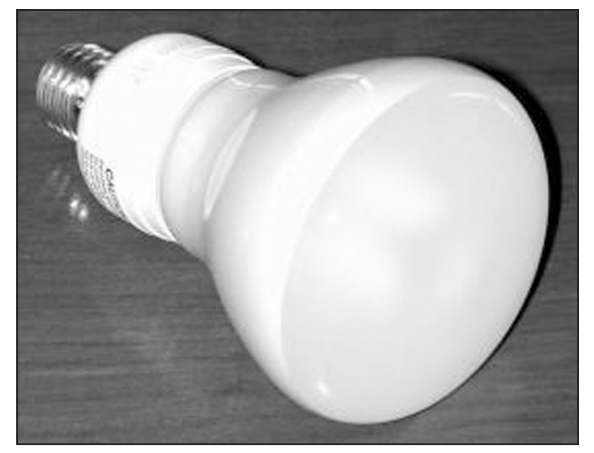

\section{Initial Research}

PNNL investigated reflector lamps to determine market potential and to see what limitations existed in the currently available R-CFL stock. In 2002, PNNL completed market and technical research on R-lamps.

Key findings include:

- The potential market for R-CFLs was large.

\section{RFP Development and Proposal Review}

After several months of industry involvement and feedback on draft minimum technical specifications, PNNL issued a request for proposals for R-CFLs intended for use in ICAT recessed can fixtures in 2002. Five manufacturers responded with proposals for 12 R-CFL models.

PNNL evaluated each model for compliance with the minimum specifications, including maximum operating temperature, overall lamp length, beam angle, and minimum light output. PNNL also conducted short-term tests (6 hours of operation in a simulated ICAT) to see if models operated within the manufacturer's rated maximum temperature. Shortterm tests verified a number of the manufacturer claims, and long-term testing was initiated on the eight models that met the minimum specifications.
- Existing R-CFLs were not widely available via traditional consumer distribution channels.

- R-CFLs were hard to find and expensive, as much as $\$ 15$ per lamp.

Performance drawbacks of existing R-CFLs included:

- Lamps did not fit well in fixtures designed for R-lamps they were too long.

- Total light output was often significantly less than their incandescent counterparts.

- Light beams were often too diffuse.

- Very few models were ENERGY STAR $^{\circledR}$ compliant, and those that were had questionable performance in high-heat environments.

- When used in ICAT cans, operating lives were suspected to be much shorter than claimed on packaging (see Figure 1).
Ambient Temperature vs. Rated Wattage

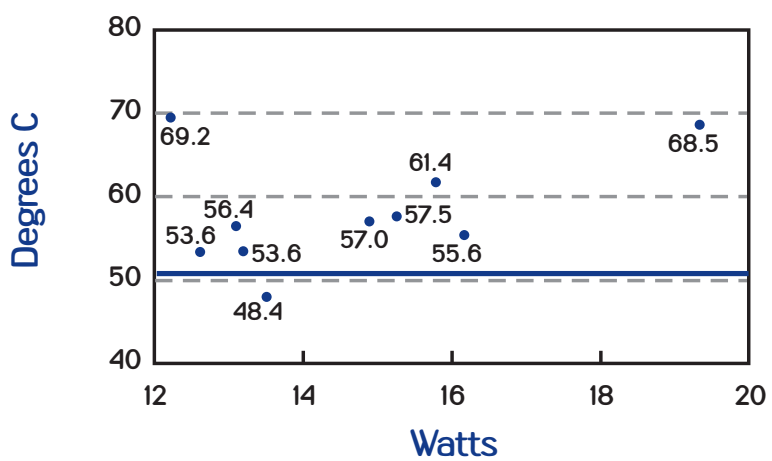

Figure 1: A sample of 10 R-CFLs tested by PNNL in a simulated ICAT fixture showed that most operated above the manufacturer's maximum operating temperature of $50^{\circ} \mathrm{C}$. 


\section{Elevated Temperature Life Testing}

The eight R-CFLs that moved into elevated temperature life testing were subjected to a minimum of 6,000 hours of operation in a simulated ICAT environment (laboratory testing). 6,000 hours is a minimum requirement for both this program and ENERGY STAR. Models with rated life claims beyond 6,000 hours are required to continue testing until that claim is met.

Ten lamps of each model were tested. The testing apparatus operated the lamps in an automated cycle of 3 hours on, 20 minutes off, for the test duration. Lamps of 16 watts or less were tested at an ambient temperature of $55^{\circ} \mathrm{C}$, while lamps

over 16 watts were tested at $60^{\circ} \mathrm{C}$ $\left(140^{\circ} \mathrm{F}\right)$. PNNL measured light intensity for each lamp every 2 weeks throughout the long-term testing process to evaluate lumen depreciation over time.

\section{Preliminary Results}

By June 2004, two of the lamp models from one manufacturer had successfully completed 6,000 hours of elevated temperature life testing. The other six models failed before 6,000 hours. (See Table 1). A failure is defined as 6 or more of the 10 lamps sampled failing before they had operated for $100 \%$ of their rated life. PNNL is evaluating the causes of the lamp failures.

\section{Key Dates}

July 25, 2003:

Initial product selections made.

September 9, 2003:

Long-term testing initiated.

June 17, 2004:

Lamps complete Long-Term Testing (at 6,000 hours rated life)

July 9, 2004:

"Winning" models announced and orders begin. PNNL and its partners begin promotional activities.

\section{Next steps}

PNNL will soon announce the winning R-CFL models. Once the manufacturer and PNNL finalize a basic ordering agreement with PNNL, the lamps will be available through a link at PNNL's R-CFL web site and other channels.

Although two lamp models successfully passed life testing, six others did not. PNNL is conducting an evaluation into the causes of the lamp failures and will share this information (without identifying manufacturer names) with industry and program partners.

PNNL intends to conduct a second phase aimed at bringing more products into the marketplace. Criteria may be changed based on results of the evaluations of the failed lamps. Phase II is planned to be launched in Fall 2004.

Table 1. Elevated-Temperature Life Testing Status as of June 1, 2004

\begin{tabular}{|c|c|c|c|}
\hline Manufacturer ID & Model ID & \# Failed (of 10) & Calculated "Rated Life" (Hours) \\
\hline A & $4 \mathrm{~A}$ & 10 & 2376 \\
\hline A & $4 \mathrm{~B}$ & 9 & 1075 \\
\hline A & $5 \mathrm{~A}$ & 7 & 3466 \\
\hline B & $8 \mathrm{~A}$ & 8 & 4520 \\
\hline B & $9 \mathrm{~A}$ & 10 & 2595 \\
\hline B & $10 \mathrm{~A}$ & 10 & 2793 \\
\hline C & $11 \mathrm{~A}$ & 1 & $6,000+|a|$ \\
\hline C & $7 A$ & 0 & $6,000+|a|$ \\
\hline
\end{tabular}

\section{For Program Information on the Web: \\ http://www.buildings.gov}

\section{For Project Information:}

Linda Sandahl

Pacific Northwest National Laboratory

Phone: (503) 417-7554

linda.sandahl@pnl.gov

\section{Reflector CFLs Website: www.pnl.gov/R-Lamps}

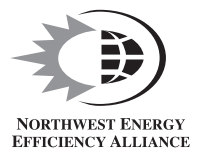

The Northwest Energy Efficiency Alliance is a non-profit group of electric utilities, state governments, public interest groups and industry representatives committed to bringing affordable, energy-efficient products and services to the marketplace.

\section{A Strong Energy Portfolio for a Strong America}

Energy efficiency and clean, renewable energy will mean a stronger economy, a cleaner environment, and greater energy independence for America. Working with a wide array of state, community, industry, and university partners, the U.S. Department of Energy's Office of Energy Efficiency and Renewable Energy invests in a diverse portfolio of energy technologies. 


\section{Pacific Northwest National Laboratory}

\section{The \\ R-CFL Challenge: Energy-Efficient, High-Performance Lamps at Volume Prices}

In many small business and congregational facilities, lighting contributes to $30 \%$ to $60 \%$ of electricity expenditures, the costs of which are accounted for on every electric bill! Reflector type compact fluorescent lamps (R-CFLs) use approximately 66\% less energy than their incandescent equivalents. Per lamp, R-CFLs can help you reduce energy costs by approximately $\$ 8$ annually, paying for themselves in about one year of operation. Given that many facilities have dozens of these lamps in areas such as offices, conference rooms, classrooms, lobbies, corridors, and exterior lighting, the savings can add up quickly!

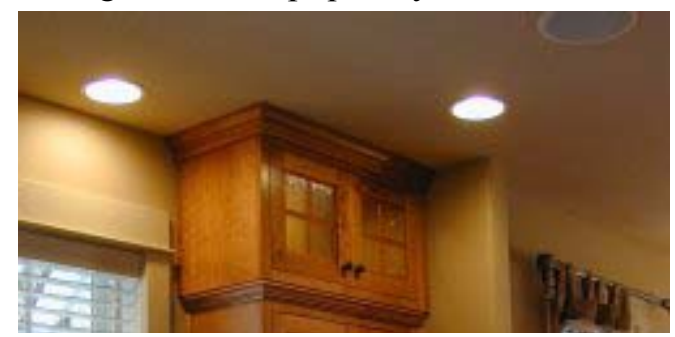

As part of a continuing effort to assist facility owners, operators, and managers in achieving reductions in lighting related energy costs, emissions, and maintenance, the R-CFL Challenge campaign is being offered by a partnership of the Pacific Northwest National Laboratory on behalf of the U.S. Department of Energy, the ENERGY STAR ${ }^{\circledR}$ Small Business and Congregations Network, Philips Lighting, and The Home Depot Supply ${ }^{\mathrm{TM}}$.

Two carefully selected, high-quality models of R-CFLs are being offered as part of this Challenge campaign at pre-arranged volume prices and free shipping within the contiguous U.S. (see order form on back of this page for details).

The lamps included in this offering are rated for 7,000 hours or more of operation, reducing costly and time-consuming lamp replacement by two to fourfold. To determine your potential energy savings from installing R-CFLs, visit http://www.pnl.gov/Rlamps/calculator.asp for an interactive savings calculator.
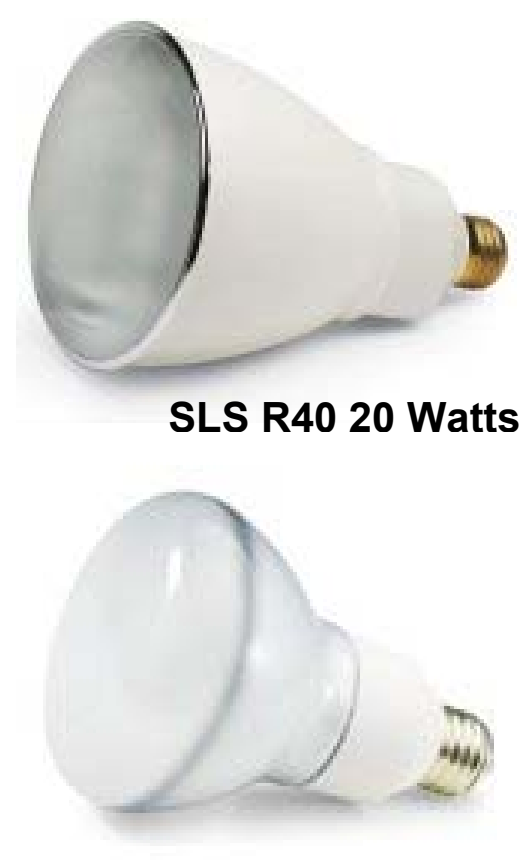

\section{EL/A BR30 16 Watts}

Detailed Specifications for each lamp can be found at the following links.

\begin{tabular}{|c|c|}
\hline Lamp & Specifications \\
\hline SLS R40 20 & http://www.pnl.gov/R-lamps/flood-r40.stm \\
\hline EL/A BR30 & http://www.pnl.gov/R-lamps/flood-r30.stm \\
\hline
\end{tabular}

To take advantage of this limited time offer simply fill out and return the order form on the back of this sheet or visit http://www.pnl.gov/R-lamps/ordering.stm.

To learn more about R-CFLs:

- Visit the R-CFL website at http://www.pnl.gov/Rlamps/about.stm,

- Download the fact sheet at http://www.pnl.gov/Rlamps/pdf/ReflectorCLF-09 04.pdf,

- Call the ENERGY STAR Small Business and Congregations Network for technical support via the ENERGY STAR hotline at 1-888-STAR-YES (1-888-782-7937), or

- Visit http://www.energystar.gov/smallbiz. 


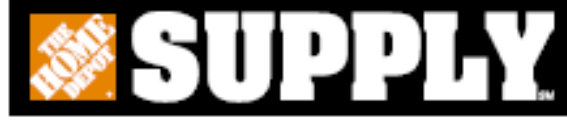

HOW TO

ORDER

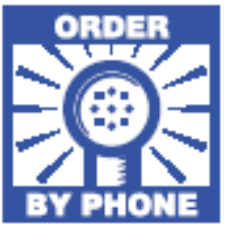

BY PHONE

\section{1-800-431-3000}

After you prepare your order, call 1-800-431-3000 Monday through Friday 7 am to 9 pm Eastern Time and one of our Customer Service Representatives will be happy to help you.

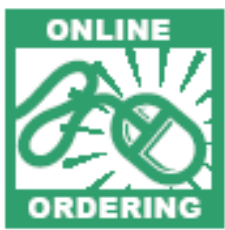

ORDER ONLINE hdsupply.com

Order what you need, when you want-online. Check out great web-only specials!

\begin{tabular}{|c|}
\hline $310949-$ EL/ABR30 \\
\hline $1-16$ cases $\ldots \ldots \ldots \ldots . . \$ 52.68 /$ case \\
$17-166$ cases ......... \$48.42/case \\
$167+$ cases ........... \$45.96/case
\end{tabular}

\begin{tabular}{|c|}
\hline $\mathbf{3 1 0 9 4 8}$ - SLS/R40 \\
\hline $1-16$ cases ............\$76.68/case \\
$17-166$ cases .........\$73.50/case \\
$167+$ cases ............\$71.40/case
\end{tabular}

PLEASE PRINT

Account \#

First \& Last Name

Order Date Purchase Order\#

SHIP TO (Property Name)

Shipping Address

City __ State Zip

Phone ( ) $\operatorname{Fax}$

PAYMENT METHOD 9 New Account

$$
\begin{aligned}
& 9 \text { American Express } 9 \text { Visa } 9 \text { The Home Depot Supply } \\
& 9 \text { MasterCard } 9 \text { Discover } 9 \text { The Home Depot }
\end{aligned}
$$

Cardholder Name (Please Print)

Cardholder Signature

Card \# Expiration Date I

Orders received by $5 \mathrm{pm}$ shipped same day

ORDER ON पर

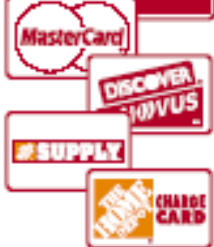
ACCOUNT OR WITH CREDIT CARDS

Charge your phone, fax, online and counter orders to your Home Depot Supply account! We also welcome credit card payments:

The Home Depot account, MasterCard, Visa, American Express, and Discover.

24 HOUR FAX ORDERS

RAPID ORDER F ORM 1-800-859-8889

Or Mail To: Customer Service, P.O. Box 509055, San Diego, CA 92150-9055 


\section{R-CFL Technology Innovation Competition}

Sixteen reflector style compact fluorescent lamps (R-CFLs) designed specifically for use in high heat applications have successfully met all specifications and testing requirements of the U.S. Department of Energy's R-CFL Technology Innovation Competition. These winning models (see Table 1) offered by four manufacturers represent a broad spectrum of lamp types, ranging from 15 to 26 watts and include parabolic aluminized reflectors, elliptical reflectors, dimmable lamps, and R-CFLs that can be used indoors or outdoors.

\section{Overview}

This two-phase effort was designed to improve the performance of screw-based R-CFLs, to increase their market availability, and to encourage new technologies and products through a competitive performance solicitation. This project is sponsored by the U.S. Department of Energy (DOE) and implemented by the Pacific Northwest National Laboratory with the cooperation and assistance of several organizations with similar interests. A number of organizations stated their intent to give buying preference to winning models, given the concern in the marketplace over the quality and performance of this category of CFLs. The winning R-CFLs have passed rigorous specifications, as well as testing requirements that simulated the environment typically found in recessed downlights.

\section{Phase 1 Winners}

Three of the 10 lamp models submitted to the R-CFL Project (Phase 1) successfully completed over 6,000 hours of elevated temperature life testing and were deemed winners in 2004 .

\section{Phase 2 Winners}

Fourteen of the 31 lamp models submitted to the R-CFL Project (Phase 2) successfully completed over 6,000 hours of elevated temperature life testing and joined the three models from Phase 1. Announcements were made in October 2006 and April 2007.

\section{How It Works}

DOE solicited from manufacturers R-CFLs that are specifically designed for use in high heat applications, such as airtight, insulated ceiling-rated recessed cans. R-CFLs that meet the program's minimum specifications and successfully complete Elevated Temperature Life Testing (ETLT) are declared competition winners. Initial evaluations, including the Short Term Acceptance Test, were completed on all models to identify those that met minimum requirements. Those that qualified were moved to ETLT.

\section{Table 1. Technology Innovation Competition Winners}

\begin{tabular}{|l|c|c|c|c|c|}
\hline Manufacturer & Model & Type & Wattage & Average Rated Life & Lumens \\
\hline GE & FLE15/2/DV/R30 & $\begin{array}{c}\text { R30 } \\
\text { Dimmable }\end{array}$ & 15 & 6,000 & 720 \\
\hline GE & FLE15/2/R30XL & R30 & 15 & 10,000 & 750 \\
\hline PHILIPS & EL/A BR30 & BR30 & 15 & 7,000 & 590 \\
\hline FEIT & ESL15R30H & R30 & 15 & 8,000 & 750 \\
\hline PHILIPS & EL/A PAR38 & PAR38 & 23 & 8,000 & 1250 \\
\hline FEIT & ESL18 PAR38H & PAR38 & 18 & 8,000 & 950 \\
\hline FEIT & BPCE23 PAR38/3 & PAR38 & 23 & 8,000 & 1300 \\
\hline GE & FLE26/2/PAR38/XL & PAR38 & 26 & 10,000 & 1300 \\
\hline PHILIPS & EL/A PAR38 & PAR38 & 20 & 8,000 & 930 \\
\hline SYLVANIA & CFE 19PAR38 & PAR38 & 19 & 10,000 & 1000 \\
\hline FEIT & ESL 18R40H & R40 & 18 & 8,000 & 950 \\
\hline FEIT & BPCE23 R40/3 & R40 & 23 & 8,000 & 1300 \\
\hline PHILIPS & EL/A R40 & R40 & 23 & 8,000 & 1250 \\
\hline GE & FLE26/2/R40XL & R40 & 26 & 10,000 & 1300 \\
\hline PHILIPS & EL/A BR40 & R40 & 20 & 8,000 & 940 \\
\hline SYLVANIA & CFEL 20BR40 & R40 & 20 & 8,000 & 900 \\
\hline
\end{tabular}

\section{See www.pnl.gov/rlamps}

for more information or how to purchase these lamps. 


\section{Minimum Specifications}

R-CFLs submitted to this competition met a number of minimum specifications (see Table 2) in addition to the ENERGY STAR Program requirements for reflector style CFLs. Models that met minimum specifications were moved to ETLT.

\section{Elevated Temperature Life Testing}

ETLT involves a minimum of 6,000 hours of operation in a simulated insulated ceilingrated airtight (ICAT) environment (laboratory testing). The minimum requirement for both this competition and the ENERGY STAR CFL Program is 6,000 hours. Models with rated life claims beyond 6,000 hours are required to continue testing until that claim is met. Ten lamps of each model are tested, and manufacturers are required to pay testing costs. The testing apparatus operates the lamps in an automated cycle of 3 hours "on," 20 minutes "off," for the test duration. Lamps are tested at an ambient temperature of $55^{\circ} \mathrm{C}$. Light intensity for each lamp is measured every 2 weeks throughout the testing period to evaluate lumen maintenance over time. Manufacturers are provided with test results for their lamp(s) on a periodic basis.

\section{Periodic Reporting of Test Results}

Check the project website http://www.pnl.gov/rlamps for periodic summaries of test results.

\section{Technology Innovation Competition Support}

Numerous utilities and energy efficiency groups have provided letters of support for this program, including:

- Northwest Energy Efficiency Alliance

- Midwest Energy Efficiency Alliance

- ENERGY STAR Small Business and Congregations

- ENERGY STAR Homes

- Consortium for Energy Efficiency, Inc.

- Northeast Energy Efficiency Partnerships and Participating Program Sponsors

- Department of Defense, Defense Logistics Agency

- Sacramento Municipal Utility District

- Snohomish County PUD No. 1

- Southern California Edison

- Wisconsin Energy Conservation Corporation.

\section{Table 2. Minimum Specifications}

\section{Feature}

\section{Operating Temperature Rating}

\section{Size Characteristics}

R30-type Products

R40-type Products

\section{Luminous Flux}

(BR, PAR, etc. products also qualify)

\section{Minimum Requirement}

Maximum ambient temperature rating of at least $50^{\circ} \mathrm{C}$ for lamps 16 watts (measured) and lower, and $60^{\circ} \mathrm{C}$ for lamps greater than 16 watts (measured). The manufacturer shall provide a maximum ambient temperature for which the warranty is valid.

Maximum Overall Length (MOL):

5.6 inches

6.6 inches

600 lumens (100 hours) minimum.

Elevated temperature luminous flux: When operated at $55^{\circ} \mathrm{C}$, lamp shall maintain $90 \%$ of 100-hour luminous flux achieved while operating at $25^{\circ} \mathrm{C}$.

\section{Beam Angle}

Maximum $120^{\circ}$

\section{A Strong Energy Portfolio} for a Strong America

Energy efficiency and clean, renewable energy will mean a stronger economy, a cleaner environment, and greater energy independence for America. Working with a wide array of state, community, industry, and university partners, the U.S. Department of Energy's Office of Energy Efficiency and Renewable Energy invests in a diverse portfolio of energy technologies.

For more information contact:

EERE Information Center

1-877-EERE-INF

(1-877-337-3463)

www.eere.energy.gov

\section{For Program Information on the Web:}

http://www.buildings.gov http://www.netl.doe.gov/ssl www.eren.doe.gov/buildings/ emergingtech

\section{For DOE Buildings Program Information on the Web: http://www.buildings.gov}

\section{For Program Information: Linda Sandahl \\ Pacific Northwest \\ National Laboratory \\ Phone: (503) 417-7554 \\ linda.sandahl@pnl.gov}

\section{Reflector CFL Website:}

www.pnl.gov/rlamps

\section{PNNL-SA-52799}

April 2007

Exception to these Requirements: Atypical and innovative R-lamp designs will be considered on an individual basis, provided 1) there is an overriding and compelling benefit, as described in the Offeror's proposal, and 2) the design is approved by the evaluation committee as being consistent with the overall purposes and intent of this RFP.
Printed on $30 \%$ post-consumer recycled paper. 
Appendix B

Retailer Survey 



\section{Appendix B - Survey of Lighting Retailers \\ CFL R-30 Lamp Questionnaire Results \\ May 13-15, 2002 DRAFT}

\section{General Information}

Forty-five lighting or electrical businesses were randomly contacted between May 13 and May 15, 2002 and asked general questions regarding CFL Reflector lamps. Among those contacted were:

- 13 lighting specialty stores,

- 24 home improvement centers,

- 5 electrical/hardware stores, and

- 3 undetermined.

The majority of the companies were selected from a list of businesses participating in the Energy Star ${ }^{\circledR}$ program. Approximately 10 were random selections made from online directories or yellow pages.

The report scope was limited to areas in and around urban settings, with 5 participants from Portland, Oregon; 6 from Los Angeles, California; 8 from Chicago, Illinois; 7 from New York, New York; 7 from San Francisco, California, 8 from Boston, Massachusetts, 1 from Houston, Texas and 3 from Atlanta, Georgia. Companies ranged from nationwide chains (Home Depot, etc.) to locally owned businesses in the suburbs.

\section{Customers}

The majority of customers served by these businesses were said to be residential buyers, though two named builders and commercial buyers as their primary customers.

\section{Knowledge of CFLs}

All of the persons queried knew the benefits of CFLs and all of them had some form of CFL (usually a twister bulb) in their store. However, 11 were unsure that CFL R-30's existed until they found them on their shelves or in a catalog. 2 stated firmly that such a product did not exist.

\section{Product Availability}

The primary question asked of each participant was, "Do you carry a CFL Reflector lamp?" If more detail was needed, a request was made for a 15-watt R-30 Reflector bulb, suitable for installation in an insulated can located in a kitchen. Of the 45 businesses contacted, 27 reported having at least one brand on the shelf, while 3 others stated they could special order the bulbs.

If the respondent said they did not carry this product, they were asked where such an item might be found. They responded as follows:

- 1 suggested searching the Internet, 
- 1 named an electrical/hardware store (Graingers),

- 2 recommended local specialty lighting stores, and

- 1 named a home improvement chain (Home Depot).

\section{Available Brands}

The following brands were available for purchase:

- $\quad$ Philips (8)

- TCP (6)

- GE (3)

- Commercial Electric (3)

- Feit (3)

- Sylvania (2)

- LOA (1)

- Rolight (1)

- Westinghouse (1)

- Sunlite (1)

- Satco (1)

- US Par (1)

GE was mentioned as an expensive brand. One person stated that Feit products were "lousy".

\section{Price}

Price ranged from $\$ 4.00$ to $\$ 45.00$, with an average price of $\$ 16.40$. Two respondents mentioned a rebate program (Wisconsin and Nstar) that offered $\$ 3.00$ off the bulbs.

The vast price difference may be in part due to a misunderstanding. Though every effort was made to describe the R-30 product thoroughly, some clerks may have given the prices of a CFL twister bulb.

\section{Perceived Drawbacks}

Most people polled had a neutral response when queried about problems. The product was new to many of them and they had very little experience with returns, complaints, etc. Some of them equated performance directly to their experience with CFL twister bulbs, which was generally positive.

These respondents that did voice a concern listed the following as potential problems:

- Product not always readily available,

- Some bulbs are too large to fit into cans, and may stick out,

- Possible difficulties with brightness (too dim or too harsh),

- Too expensive.

These respondents were from stores located in X states.

Some salespeople talked about the differences in covered and uncovered reflector bulbs, but only two noted that a bare bulb might not be aesthetically pleasing. 


\section{Alternatives to a CFL Reflector Bulb}

Seven respondents said they would strongly ure a potential buyer to try a halogen bulb instead of a CFL R lamp. They listed the following benefits of choosing this bulb over a CFL R-30 lamp:

- Cheaper,

- Readily available,

- Bright, crisp light,

- Though not as energy efficient as a CFL, did use less wattage than an incandescent.

A few people suggested installing a twister bulb directly into the can. Some noted that without a reflector, the light might be dim and shadowy, but others felt this would be an adequate alternative to an R-30 lamp.

\section{Is there Customer Demand?}

The impression given was that the popularity of the CFL twister bulbs encouraged store buyers to pick up a few R-30 reflector bulbs as well, but the product is not yet market-driven. Almost all the home improvement stores had plenty of stock on hand, but many of the specialty stores had limited quantities or had to order from a catalog. One of them stated that he had only sold 13 R-30 reflector bulbs last year.

The fact that many respondents were unaware they had the product on their shelves also shows a lack of customer demand.

\section{Conclusions}

Most of the salespersons contacted for this survey knew what a CFL Reflector bulb was and many could list the benefits of the product, primarily because of their experience selling CFL twister bulbs. Only one respondent had a completely negative response to R-lamps; other responses ranged from neutral to mildly enthusiastic about the benefits of such a product.

CFL R-30's appear to be less popular than the twister bulbs, possibly because customers are simply unaware of their existence. An aggressive marketing campaign similar to the efforts used to promote subCFLs might prove beneficial. Educating salespeople would also be a consideration, as so many of them did even know they carried the product in their store.

Price and quality of light appear to be the top reasons someone might chose a different product (such as a halogen) over a CFL reflector bulb. Salespeople often cautioned that a price was "high" if it was \$20 or more. The CFL R-lamp was occasionally described as "slow to start" "dim" or "harsh". New products priced below $\$ 20$ and guaranteed to produce incandescent-like light will likely be successful.

In virtually every store, only one brand of CFL R-lamp could be purchased, so there was no possibility that a potential buyer could compare prices and benefits. This is possibly due to the fact that since the product is so new and demand relatively low, only one brand is necessary to satisfy the client-base of the store.

Several brands are currently vying for shelf space. This competition may eventually drive down prices and encourage manufacturers to develop superior products in their efforts to grab market share. 
B. 4 
Appendix C

\section{RFP Cover Letters and Excerpts}





\title{
RFP Phase 1 Request for Proposal No. 411205
}

[Cover Letter]

\author{
Pacific Northwest \\ National Laboratory \\ Operated by Battelle for the \\ U.S. Department of Energy
}

October 25, 2002

Dear Offeror:

Compact Fluorescent Reflector Lamp Request for Proposal (RFP)

Battelle Memorial Institute, Pacific Northwest Division, Pacific Northwest National Laboratory (Battelle) is interested in receiving proposals for furnishing and delivery of screw-base compact fluorescent reflector lamp products specifically designed for application in insulated ceiling rated, airtight recessed fixtures needed in connection with Battelle's management, operation and maintenance of the U.S. Department of Energy's (DOE) Pacific Northwest National Laboratory (PNNL) at Richland, Washington, under Prime Contract DE-AC06-76RL01830.

Information regarding the product and services required and instructions for the preparation and submission of proposals are contained in the attached RFP.

Requests for explanation or interpretation should be submitted in writing by November 7, 2002 to the following address:

Battelle Washington DC Operations Office

Pacific Northwest National Laboratory

Attn: Leslie Nicholls

901 D St., SW, Suite 900

Washington, D.C. 20024

Requests may also be emailed to le.nicholls@pnl.gov. Requests for explanation or interpretation along with responses will be provided to all RFP recipients without identification of the requestor. Proposals are due by November 22, 2002.

Sincerely,

Leslie Nicholls

Associate Manager, Contracts

Enclosures 
REQUEST FOR PROPOSAL NO. 411205 -- Excerpts

ENCLOSURE 2 STATEMENT OF WORK

\subsection{Introduction}

The U.S. Department of Energy's (DOE) Pacific Northwest National Laboratory (PNNL) at Richland, Washington is interested in receiving proposals for furnishing and delivery of screw-base compact fluorescent reflector lamp (CFL) products specifically designed for application in insulated ceiling rated (IC), airtight (AT) recessed fixtures. The Pacific Northwest Division of Battelle Memorial Institute (Battelle) operates PNNL for DOE under Prime Contract DE-AC06-76RL01830 and is the legal entity issuing this RFP. CFL's will not be purchased by PNNL nor the DOE under any resulting award. The sole purpose of this solicitation is to enable independent CFL buyers to purchase directly from selected suppliers under this program.

\section{BACKGROUND}

In support of the U.S. Department of Energy, the Northwest Energy Efficiency Alliance, and others, PNNL is organizing a program to speed the commercial introduction and early market acceptance of CFL reflector products suitable for operating in IC/AT recessed downlights.

DOE has determined that, given the market size and the number of "off the shelf" technology solutions, there is a significant opportunity to improve the performance and market acceptance of CFL reflector products for IC/AT downlight applications. This program is using a DOE process called technology procurement to speed commercialization of new products. (See Attachment 1 for a general description of technology procurement, and Attachment 2 for a description of this R-Lamp technology procurement.)

This program focuses specifically on CFL reflector products used in existing single and multi-family residences and low rise commercial buildings. The program is promoting sales of CFL reflector products to intermediate buyers, such as large volume retailers and electrical wholesalers; end use buyers, such as public agencies and production builders; as well as companies and organizations that can influence the intermediate and end use buyer market, such as electric utilities. The program has three main elements:

1. interaction with potential large volume buyers of these products (such as home centers/retailers and production builders) and organizations that influence these buyers (such as electric utilities and energy conservation organizations) to help define the desired characteristics and to develop interest in their purchase;

2. award of basic ordering agreements to selected Offerors that stipulate the prices and terms of supplying new products through this program to participating large volume buyers;

3. promotion of the products made available through this program to potential large volume buyers, in cooperation with electric utilities and energy conservation organizations.

This technology procurement is designed to address the following technical problems common among CFL reflector products presently in the market:

1. Inadequate light output and extremely wide beam spread compared to incandescent flood-type R-lamps.

2. Excessive lamp length that causes fit and glare problems in recessed downlights.

3. Reduced lumen output and lamp life resulting from high lamp and ambient temperatures when operated within IC/AT recessed downlights.

This technology procurement is designed to help introduce new products to address the above technical problems and is expected to provide large volume buyers with better performing CFL reflector products. The ultimate goal of the program is to substantially increase the market availability of CFL reflector products suitable for operation in IC/AT recessed downlights. 
Recessed downlights are by far the most popular residential fixture. The U. S. Census Bureau reported that about 21.6 million residential recessed fixtures were sold in 2000. Although precise figures on the number of installed recessed downlights fixtures are not available, we estimate 350 million are installed in residential buildings, with almost all using incandescent light sources. The U.S. Department of Energy and the Northwest Energy Efficiency Alliance, as well as numerous other utility and market transformation organizations are interested in promoting CFL reflector products selected as part of this program. See Attachment 3 Expressions of Interest from Potential Large Volume Buyers, Electric Utilities, and Conservation Organizations for copies of letters of support. Based on this, and other information, the product sales goal for this program is 1 million lamps over a 2 year period. A significant market opportunity exists for those suppliers who produce a product that can successfully compete with incandescent reflector products.

PNNL is seeking supplier(s) to supply CFL reflector products to a variety of buyers and provide superior warranty and return services. Selected suppliers will be awarded Basic Ordering Agreements (BOA) [Enclosure 5] with a 12-month period of performance, with an option for an additional 12-month period of performance, to be exercised at the sole discretion of PNNL. Neither DOE, PNNL, nor other cooperating organizations intend to directly purchase CFL reflector products. PNNL is acting in a third party role.

Successful Offeror(s) under the program shall be responsible for having complied with all applicable Federal and state regulatory and safety standards, regulations, and laws concerning these types of CFL reflector products. This includes certification of safety, Federal Communications Commissions standards on electromagnetic interference from fluorescent lighting. All Offerors must have the authority to sell product throughout the United States and it's territories.

Offerors that are selected under this program (successful Offerors) will sign a BOA, and will become suppliers of CFL reflector products with specific prices, terms, and conditions. Program buyers will purchase CFLs according to a schedule of maximum delivered prices and other conditions agreed to by the successful Offeror(s) on this solicitation. The Offerors will be expected to supply CFL reflector products meeting the technical requirements in this statement of work, following an announced delivered price schedule, and backed by the warranty and return policies and procedures discussed below.

\subsection{CFL Reflector Product REQUIREMENTS}

The Offeror shall provide a detailed description of the CFL reflector products being offered for sale under this contract. The following are the minimum specifications that shall be met by any CFL Reflector Product delivered under this contract. Offers that do not meet the minimum technical specifications will be deemed nonresponsive and be automatically rejected.

\subsection{Mandatory Qualification Requirements}

\section{A. Technical Requirements}

The Offeror shall self-certify or provide proof of certification that each CFL Reflector Product proposed meets or exceeds the following technical requirements. Six (6) samples of each R-lamp model offered shall be included with the proposal for evaluation. These lamps will not be returned to the Offeror.

1. CFL reflector products shall comply with ENERGY STAR ${ }^{\circledR}$ CFL Specifications under Scope D: single based compact fluorescent lamps with integral electronic ballasts and which have a reflector that may be open or closed. The lamp will be intended to replace primarily wide beam incandescent reflector lamps. ENERGY STAR CFL Specifications can be found at: http://www.energystar.gov/products/cfls/EnergyStarCFLSpecification_Final_8.9.01.pdf

It is expected that some CFL reflector products, especially newer models, will not have ENERGY STAR approval at the time of submission to this procurement. In cases where a lamp model is currently undergoing ENERGY STAR testing, the manufacturer shall provide and expected approval date. Manufacturers with new lamp models, or existing models that have not been submitted to ENERGY STAR for approval, should indicate 1) submission date 
(anticipated in some cases), and 2) expected approval date. These lamp models are eligible for inclusion in this procurement, but only after ENERGY STAR approval is attained.

2. In addition, proposed products shall also comply with the following specifications:

Table 1. CFL reflector products for Insulated Ceiling, Airtight fixtures

\begin{tabular}{|c|c|c|}
\hline Feature & Minimum Requirement & Verified By \\
\hline $\begin{array}{l}\text { Operating Temperature } \\
\text { Rating }\end{array}$ & $\begin{array}{l}\text { Maximum Ambient Temperature } \\
\text { rating of at least } 60^{\circ} \mathrm{C} \text {. The offeror } \\
\text { shall provide a maximum ambient } \\
\text { temperature for which the warranty } \\
\text { is valid, and for which the } \\
\text { manufacturer believes the lamp can } \\
\text { reliably operate. }\end{array}$ & $\begin{array}{l}\text { Laboratory tests will be conducted on lamp samples in } \\
\text { a simulated insulated ceiling environment. (See Section } \\
\text { 4.) Measured ambient temperatures shall not exceed } \\
\text { the maximum rated ambient temperature for the } \\
\text { products }\left(60^{\circ} \mathrm{C} \text { minimum). }\right.\end{array}$ \\
\hline $\begin{array}{l}\text { Electrolytic Capacitor(s) } \\
\text { Rating }\end{array}$ & $\begin{array}{l}\text { R-lamp electrolytic capacitor(s) } \\
\text { rating of at least } 125^{\circ} \mathrm{C} \text { with a } \\
\text { minimum operating life of } 5,000 \\
\text { hours. }\end{array}$ & $\begin{array}{l}\text { Offeror shall state the type of electrolytic capacitor(s) } \\
\text { used, and its (their) manufacturer-specified maximum } \\
\text { operating temperature, as well as the manufacturer- } \\
\text { specified operating life for the capacitor at that } \\
\text { temperature. } \\
\text { The operational life/mortality curve/Mean Time To } \\
\text { Failure (MTTF) should be specified for the electrolytic } \\
\text { capacitor. } \\
\text { Laboratory tests will be conducted on lamp samples in } \\
\text { a simulated insulated ceiling environment. (See Section } \\
\text { 4) Measured electrolytic capacitor operating } \\
\text { temperatures shall not exceed the maximum rated } \\
\text { operating temperature for the capacitor ( } 125^{\circ} \mathrm{C} \\
\text { minimum). }\end{array}$ \\
\hline $\begin{array}{l}\text { Size Characteristics } \\
\text { R30-type Products } \\
\text { R40-type Products } \\
\text { (BR, PAR, etc. products } \\
\text { also qualify) }\end{array}$ & $\begin{array}{l}\text { Maximum Overall Length (MOL): } \\
5.6 \text { inches } \\
6.6 \text { inches }\end{array}$ & MOL measured and verified by PNNL. \\
\hline Luminous Flux & $\begin{array}{l}500 \text { lumens (initial) minimum, when } \\
\text { operated in a simulated insulated } \\
\text { ceiling environment. } \\
\text { When operated at } 60^{\circ} \mathrm{C} \text {, lamp shall } \\
\text { maintain } 90 \% \text { of luminous flux } \\
\text { achieved while operating at } 25^{\circ} \mathrm{C} \text {. }\end{array}$ & $\begin{array}{l}\text { Offeror shall provide IESNA LM-66-2000 Electrical } \\
\text { and Photometric Measurements of Single-Ended } \\
\text { Compact Fluorescent Lamps report with their } \\
\text { submittal. } \\
\text { Laboratory tests will be conducted on lamp samples in } \\
\text { a simulated insulated ceiling environment by PNNL. } \\
\text { (See Section 4.1.) }\end{array}$ \\
\hline Beam angle & Maximum 120 degrees. & $\begin{array}{l}\text { Offeror shall specify beam angle in proposal. } \\
\text { Photometric testing of beam angle in accordance with } \\
\text { IESNA tests LM-20 and LM-9 from an accredited } \\
\text { laboratory shall be provided. }\end{array}$ \\
\hline Color Rendering Index & 80 or higher & Self certify. \\
\hline $\begin{array}{l}\text { Correlated Color } \\
\text { Temperature }\end{array}$ & $2700-3000 \mathrm{~K}$ & Self certify. \\
\hline \multicolumn{3}{|c|}{$\begin{array}{l}\text { Exception to these Requirements: R-lamp designs that meet the intent of this procurement through atypical/innovate lamp } \\
\text { designs will be considered on an individual basis, provided, 1) there is an overriding and compelling benefit, as described in } \\
\text { the Offeror's proposal and; 2) is approved by the evaluation committee as being consistent with the overall purposes of this } \\
\text { RFP. }\end{array}$} \\
\hline
\end{tabular}




\section{Delivery}

Offeror shall discuss delivery schedule and service in the response to this solicitation. Offerors will be required to begin taking orders for lamps within 120 days after signing a Basic Ordering Agreement with PNNL.

Offeror shall provide delivery to buyers at prices to be specified in the response to this solicitation. Deliveries shall be made within 30 calendar days from receipt of a customer's order.

\subsection{Warranty and Other After-Sale Service}

Offeror shall offer a standard warranty service package fully covering product performance and failure for one year from date of purchase (Energy Star minimum is one year). Offerors are encouraged to offer superior warranty service and maximum convenience to customers; for example, including agreements with retailers to accept for refund or replacement inoperable products that are returned by customers, or prepaid shipping agreements with express package delivery firms. Offeror shall attach the text of applicable warranty features and conditions.

\section{$2.4 \quad$ Price}

The Offeror shall fill out the attached price schedules (Enclosure 3) for all locations to facilitate the review. Note that these are maximum prices. If later market circumstances warrant, the Offeror is free to reduce any price offered in response to this solicitation.

Note: Shipping costs to Zone 5 locations can vary by an order of magnitude, depending on the method of shipping (postal service, air freight, etc.) chosen. For Zone 5 in particular, please bid the least expensive method of delivery that will provide delivery within 30 calendar days of receipt of order.

\subsection{Responsibilities of the Parties}

The successful Offerors are expected to become suppliers of CFL reflector products covered by this solicitation to the buyers participating in this program.

\subsection{Manufacturer Contact Information}

Suppliers are required to provide a toll-free telephone number and a toll-free fax number, which PNNL will make available to buyers via a web site and printed promotional literature. Suppliers are encouraged to provide product brochures and graphics suitable for placement on a promotional web site, which PNNL will maintain. The web site will provide an overview of the CFL Reflector Product Program, a description of the products available, and the tollfree telephone and fax numbers of the suppliers. If a supplier provides an Internet link for direct Internet ordering, PNNL will include that link and related information in the CFL Reflector Product web site.

\subsection{Program Promotion}

The U.S. Department of Energy and PNNL will promote this program at the national level through news releases and publications, and will feature the roles of the participating suppliers in these promotional materials. The Northwest Energy Efficiency Alliance (Alliance) will promote products for which a Basic Ordering Agreement has been established via the Energy Star Residential Lighting Program in the states of Oregon, Washington, Idaho, and Montana. Those products will also be promoted and made available for purchasing on the Alliance's web site, BetterBulbsDirect.com.

\subsection{Reporting}

For the purpose of evaluating the program in saving energy and consumer costs, suppliers will be required to report the volume of sales under this program to PNNL on a monthly basis. Sales information will not be reported, except in aggregate, and specific manufacturer sales will be treated as confidential. The following is an outline of the required information to be delivered to PNNL. 
a. Reporting shall be done via electronic mail to PNNL on the $3^{\text {rd }}$ working day of each month and shall include the following:

- $\quad$ Number of CFL reflector products shipped in the previous month, by model

- Number of CFL reflector products acquired through this program that were serviced or replaced under warranty.

b. For each recessed CFL Reflector Product order received, the supplier shall use their best effort to collect and maintain, for reporting purposes, the following:

- Type of company placing the order, builder, retailer, wholesaler, government (federal, state, city), or other.

\subsection{Acceptance Test}

Lamps shall be tested, listed , and labeled by an organization accredited by the National Voluntary Laboratory Accreditation Program (NVLAP) or the American Association for Laboratory Accreditation (A2LA) as having the capability for testing, listing, and labeling CFLs. These organizations include Underwriters Laboratories (UL), Intertek Testing Services Performance Division (formerly ETL Testing Laboratories), Factory Mutual, and others. Listing and labeling are as defined in the National Electrical Code.

A combination of short-term and life testing will be employed by PNNL to select CFL reflector products as part of this procurement. Lamps will undergo initial short-term testing (described in section 4.1) to demonstrate compliance with certain minimum specifications listed in Table 1. Lamp models that meet the minimum qualifications, pass the short-term testing, and are determined to be in a competitive range in the technical and cost evaluation will be selected for inclusion in the life testing phase of this program Full life testing is explained in section 4.2. Manufacturers will be expected to cover the cost of full life testing,

\subsection{Short-Term Acceptance Test}

Short-term tests will be conducted at no cost to the manufacturer, and will target the Maximum Ambient Temperature and the Electrolytic Capacitor.

\subsubsection{Test Apparatus}

Lamps will be tested in an IC airtight recessed downlight fixture installed in an apparatus designed to simulate an insulated ceiling environment. The test apparatus is constructed of $1 / 2$ " plywood and cut to create a 24 "wide $\mathrm{x}$ 24"deep x 18" high box equipped with a "tight fitting" lid. In addition, 2" of polyisocyanurate (R-7.2) rigid board insulation is applied to the outside of the four (4) side panels. A standard IC rated, airtight, incandescent fixture will be installed in the base of the apparatus. Loose-fill cellulose insulation will be installed to a depth of 12 inches. See Attachment 4 for a schematic of the test apparatus.

\subsubsection{Maximum Ambient Temperature Testing}

Maximum ambient temperatures will be measured over a six (6) hour time period. A temperature sensor will be positioned at a point midway between the centroid of the lamp ballast and the sidewall of the recessed fixture housing. This reading will be used for determining compliance and for allocating points (beyond the minimum requirement) for scoring purposes. See Attachment 4 for a schematic of the measurement location.

\subsubsection{Electrolytic Capacitor Testing}

The temperature of the primary electrolytic capacitor will be measured over a six (6) hour period (concurrent with maximum ambient temperature testing). The manufacturer shall provide an access hole(s) in the ballast casing of one of the six lamps submitted with the proposal. This hole must be no smaller than $1 / 4$ ", and is needed to allow testing of the electrolytic capacitor. The location of the access hole will be determined by the manufacturer and shall be in such a location as to facilitate access to the electrolytic capacitor for attachment of the temperature 
probe. The temperature probe shall be "thermally cemented" directly to the primary electrolytic capacitor and the access hole sealed with silicone caulking. This temperature reading will be used to verify the steady-state operating temperature of the electrolytic capacitor and will be used in allocating points for scoring purposes.

\subsection{Life Testing}

Lamp models that are successful in the Short-Term Acceptance Test and are selected based upon the evaluation criteria, will be moved into Life Testing. Life testing consists of 6,000 hour rated life testing in a test apparatus capable of maintaining $60^{\circ} \mathrm{C} \pm 10^{\circ} \mathrm{C}$ and otherwise following the IESNA LM-65-1991 Life Testing of Single-Ended Compact Fluorescent Lamps test procedure. Lamp models that claim an average rated life greater than 6,000 hours (minimum for ENERGY STAR qualification) must complete a rated life test consistent with their rated life. A sample size of ten (10) lamps for each model will be subjected to the test. These lamps must be supplied to the test facility by the manufacturer.

\subsubsection{Cost to the Manufacturer}

Manufacturers will be expected to cover the cost of full life testing, which is expected to cost $\$ 3,000$ - $\$ 4,000$ per model.

\subsection{Confidentiality}

Test results and other proposal-related information will be treated as business sensitive/confidential and will be shared only with the PNNL proposal evaluation committee and the manufacturer.

\section{Substitutions and Additions.}

After Basic Ordering Agreements are signed pursuant to this RFP, suppliers will be allowed to offer either additional models of CFL Reflector products, to substitute new models for models previously offered, or both. PNNL will determine whether to permit these additions or substitutions under the agreements, on the basis of whether such additions or substitutions appear to be in the best interests of the buyers, and the supplier's past performance under the agreement (e.g., experience to date with the supplier's product performance, delivery record, and related services). To be in the buyers' best interest, the new product offering must score at least as well as existing products on the Phase 2 evaluation criteria or offer significant other benefits (e.g., new features or exceptional durability), or both, as determined by PNNL. 


\section{PRICE SHEET}

Quote your best price, delivery on the models described below and as described in the attached specification. Price evaluation will be performed on the best delivered price (item 1 plus item 2). Provide a separate price sheet for each model of CFL reflector product. Make extra copies of this sheet as necessary.

Model \#:

Rated Lamp Wattage:

\begin{tabular}{|c|c|c|c|c|c|c|c|}
\hline \multirow[t]{2}{*}{ Item } & \multirow[t]{2}{*}{ Description } & \multirow[t]{2}{*}{$\begin{array}{l}\text { Delivery } \\
\text { Zone }\end{array}$} & \multicolumn{5}{|c|}{$\begin{array}{l}\text { Price per CFL reflector product by Size of Order } \\
\text { (Please state your minimum order size below. It must not be } \\
\text { more than 10) }\end{array}$} \\
\hline & & & $\begin{array}{l}\text { Minimum } \\
\text { quantity: }\end{array}$ & $\begin{array}{l}11-99 \\
\text { Units }\end{array}$ & $\begin{array}{l}\text { 100-500 } \\
\text { Units }\end{array}$ & $\begin{array}{l}\text { 501-999 } \\
\text { Units }\end{array}$ & $\begin{array}{l}1000+ \\
\text { Units }\end{array}$ \\
\hline 1 & $\begin{array}{l}\text { Supply CFL reflector } \\
\text { product and } 2 \text { year } \\
\text { warranty to buyers }\end{array}$ & N/A & & & & & \\
\hline \multirow[t]{5}{*}{2} & \multirow[t]{3}{*}{ Delivery Charges } & $\begin{array}{l}\text { Zone 1, per } \\
\text { Unit }\end{array}$ & & & & & \\
\hline & & $\begin{array}{l}\text { Zone 2, per } \\
\text { Unit }\end{array}$ & & & & & \\
\hline & & $\begin{array}{l}\text { Zone 3, per } \\
\text { Unit }\end{array}$ & & & & & \\
\hline & \multirow{2}{*}{$\begin{array}{l}\text { Note: see special } \\
\text { instructions for Zone } \\
5 \text { in Section } 2.6 \text { of } \\
\text { the Statement of } \\
\text { Work, Enclosure } 3\end{array}$} & $\begin{array}{l}\text { Zone 4, per } \\
\text { Unit }\end{array}$ & & & & & \\
\hline & & $\begin{array}{l}\text { Zone 5, per } \\
\text { Unit }\end{array}$ & & & & & \\
\hline Zone & \multicolumn{7}{|c|}{ Geographic Area (Postal Code for State or Territory) } \\
\hline 1 & \multicolumn{7}{|c|}{ AL, CT, DE, DC, FL, GA, KT, ME, MD, MA, MS, NH, NJ, NY, NC, PA, RI, SC, TN, VT, VA, WV } \\
\hline 2 & \multicolumn{7}{|c|}{ AR, IL, IN, IA, KS, LA, MI, MN, MO, NE, NM, OH, OK, TX, WI } \\
\hline 3 & \multicolumn{7}{|c|}{ AZ, CA, CO, ID, MT, NV, ND, UT, OR, SD, WA, WY } \\
\hline 4 & \multicolumn{7}{|l|}{ AK, HI, PR } \\
\hline 5 & \multicolumn{7}{|c|}{$\begin{array}{l}\text { AS (American Samoa), FM (Federated States of Micronesia), GU (Guam), MH (Marshall Islands), } \\
\text { MP (Northern Mariana Islands), VI (U.S. Virgin Islands) }\end{array}$} \\
\hline
\end{tabular}




\section{ENCLOSURE 4 EVALUATION CRITERIA}

A technical evaluation team has been appointed to evaluate the proposals. Offers demonstrating the ability to meet all Mandatory Qualification Requirements (Enclosure 2, Section 2) will be determined responsive. Responsive proposals will be awarded points on technical merit. Proposals will be reviewed to determine the Offeror whose proposal contains the combination of those criteria offering the best overall value to PNNL and its partners. PNNL will not make an award at a significantly higher overall cost to achieve slightly superior technical features.

Responsive technical proposals shall be scored on a weighted numerical scale based upon the following:

1. Technical requirements

1. Proposals that do not meet the Mandatory Qualification Requirements criteria in Enclosure 2, Section 2 will not be considered responsive to the RFP and will not be evaluated further.

2. Points will be awarded according to the following criteria:

a. High Operating Temperature Tolerance Points will be awarded to submissions that exceed the minimum requirements for maximum rated operating temperature and maximum electrolytic capacitor operating temperature.

i. Rated ambient temperature of at least $60^{\circ} \mathrm{C}$. Points will be awarded for ambient temperature ratings higher than the minimum.

ii. R-Lamp capacitor rating of at least $125^{\circ} \mathrm{C}$ and operating life of 5,000 hours. Points will be awarded for temperature ratings/rated life higher than the minimum.

b. Beam Angle and Intensity Points will be awarded based upon the degree to which proposed CFL reflector product models achieve a tighter beam angle beyond the minimum specification.

c. Superior Warranty and Return Service Points will be awarded based on the extent to which the warranty of the CFL reflector products offered exceeds the minimum 1 year requirement plus return services including, but not limited to: warranty terms exceeding the 1-year minimum, offers to pay the full shipping costs for returning failed products, and other offers to improve the convenience to customers to exercise their warranty rights.

2. Price

1. Pricing will be evaluated upon the per CFL reflector product delivered price to buyers in the five delivery zones and from the lowest to highest based on a percentage algorithm relative to the other offers.

3. Scoring Matrix and Weighting:

1. Selection criteria and approximate weightings are presented in the Scoring Matrix below.

\section{Scoring Matrix}

\begin{tabular}{|l|l|}
\hline Selection Criteria & Scoring \\
\hline High Operating Temperature Tolerance & $40 \%$ \\
\hline Price to buyer & $25 \%$ \\
\hline Beam angle & $25 \%$ \\
\hline Superior warranty and return service & $10 \%$ \\
\hline Total: & $100 \%$ \\
\hline
\end{tabular}




\title{
Phase 2 Request for Proposal R-CFL Technology Innovation Competition
}

\author{
Pacific Northwest \\ National Laboratory \\ Operated by Battelle for the \\ U.S. Department of Energy
}

[Cover Letter]

June 3, 2005

Dear Offeror:

Request for Proposal: Reflector Compact Fluorescent Lamp (R-CFL) Technology Innovation Competition.

On behalf of the U.S. Department of Energy, Battelle Memorial Institute, Pacific Northwest Division, Pacific Northwest National Laboratory (PNNL), in cooperation with utility and market transformation groups across the U.S. are developing a national initiative entitled: Reflector Compact Fluorescent Lamp (R-CFL) Technology Innovation Competition.

The Technology Innovation Competition is a method to pull new technologies and products into the marketplace through competitive solicitations backed by large volume buyers and organizations that promote energy-efficient lighting products. The goal of this effort is to encourage the introduction and sales of new, Reflector CFLs (R-CFLs) designed specifically for application in residential Insulated Ceiling (IC) rated, airtight (AT) recessed can fixtures, and help build their initial sales. These hightemperature applications pose a lamp design challenge to manufacturers, since extreme heat can cause reduced lamp life and lumen degradation.

PNNL is requesting proposals in response to this Technology Innovation Competition. A copy of this RFP, as well as letters of support from program partners, can be found at

www.pnl.gov/rlamps/phase2.stm. PNNL requests proposal be submitted by July 18, 2005. However, the proposal acceptance period will remain open through August 29, 2005. Any offeror planning to submit a proposal after July 18, but prior to August 29, must inform PNNL of the intention to submit a proposal by sending the Notification of Intention to Bid form, Enclosure 1 to:

Battelle/PNNL

Leslie Nicholls

901 D. Street SW

Suite 900

Washington, DC 20024

Or via email to: le.nicholls@pnl.gov. The Notification of Intention to Bid form may also be faxed to 202646-7899, attention Leslie Nicholls.

The extended proposal acceptance period is intended to allow manufacturers more time to prepare submissions. R-CFL proposals that are submitted by July $\mathbf{1 8}$ will be included in the initial round of testing and therefore have the potential to become available to buyers sooner. 
Selected R-CFLs from a previous DOE project with similar specifications, the R-CFL Technology Procurement Project, can be reviewed at http://www.pnl.gov/rlamps. The specifications for this R-CFL Technology Innovation Competition differ from the R-CFL Technology Procurement in a number of ways, primarily:

Luminous Flux - Phase 2 requires 600 lumens (initial) minimum, when operated in a simulated insulated ceiling environment. Minimum initial lumens in Phase 1 were 500. Other luminous flux requirements remain the same.

Electrolytic Capacitor Rating - There is NO stipulation for electrolytic capacitors temperature rating or operating life in Phase 2 . The Phase 2 specification is strictly performance based. Manufacturers should keep in mind however that higher quality electrolytic capacitors will likely be needed in order to meet the performance requirements listed in this specification.

A Pricing Proposal is not requested as part of this R-CFL Technology Innovation Competition Request for Proposal. Manufacturers will be requested to provide prices for various quantities of selected models if they would like PNNL to provide this information on the project web site and via other promotional avenues.

As with the R-CFL Technology Procurement, there is an Exception to the Minimum Requirements - Rlamp designs that meet the intent of this procurement through atypical/innovate lamp designs will be considered on an individual basis, provided, 1) there is an overriding and compelling benefit, as described in the Offeror's proposal and; 2 ) is approved by the evaluation committee as being consistent with the overall purposes of this RFP.

Information regarding the product and services required and instructions for the preparation and submission of proposals are contained in the attached RFP.

Requests for explanation or interpretation should be submitted in writing by July 112005 to the following address:

\author{
Battelle Washington DC Operations Office \\ Pacific Northwest National Laboratory \\ Attn: Leslie Nicholls \\ 901 D St., SW, Suite 900 \\ Washington, D.C. 20024
}

Requests may also be emailed to le.nicholls@pnl.gov. Requests for explanation or interpretation along with responses will be provided to all RFP recipients without identification of the requestor.

Thank you for your consideration. We look forward to your response.

Sincerely,

Leslie Nicholls

Associate Manager, Contracts 


\title{
RFP Phase 2 Request for Proposal R-CFL Technology Innovation Competition - Excerpts
}

\author{
ENCLOSURE 2 R-CFL INNOVATION COMPETITION PROGRAM OVERVIEW
}

Introduction

The U.S. Department of Energy's (DOE) Pacific Northwest National Laboratory (PNNL) at Richland, Washington, is interested in receiving proposals for screw-base compact fluorescent reflector lamps (R-CFL) specifically designed for application in insulated ceiling-rated (IC), airtight (AT) recessed downlight fixtures. The Pacific Northwest Division of Battelle Memorial Institute (Battelle) operates PNNL for DOE under Prime Contract DEAC06-76RL01830 and is the legal entity issuing this RFP. R-CFLs will not be purchased by PNNL or the DOE under any resulting award. The purpose of this Technology Innovation Competition is to facilitate the purchase of R-CFLs which meet the requirements and mandatory technical specifications included in Enclosure 3 by program partners and other independent CFL buyers.

\section{Program Overview}

In support of the U.S. Department of Energy, PNNL is organizing a second phase of a two-phase project to speed the commercial introduction and early market acceptance of R-CFLs suitable for operating in IC/AT recessed downlights. PNNL has determined that, given the market size for CFLs and the number of "off the shelf" technology solutions, there is a significant opportunity to improve the performance and market acceptance of R-CFLs for IC/AT downlight applications.

This competition focuses specifically on R-CFLs used in existing or new single and multi-family residences and low-rise commercial buildings. The program is promoting sales of R-CFLs to large-volume buyers, such as retailers, electrical wholesalers, public agencies, production builders, electric utilities, and energy-efficiency organizations.

The program has three main elements:

1) interaction with potential large volume buyers of these products (such as home centers/retailers and production builders) and organizations that influence these buyers (such as electric utilities and energy conservation organizations) to help define the desired characteristics and to develop interest in their purchase;

2) award of Teaming Agreements to selected successful Offerors that stipulate each party's role in this program;

3) promotion of the products made available through this program to potential large volume buyers, in cooperation with electric utilities, retailers, and energy conservation organizations.

This program is designed to address the following technical challenges commonly identified in R-CFLs currently in the market:

1) Inadequate light output and extremely wide beam spread compared to incandescent flood-type R-lamps.

2) Reduced lumen output and lamp life resulting from high ambient temperatures when operated within IC/AT recessed downlights.

The objective of this technology innovation is to help introduce new products to address the above mentioned technical challenges. The ultimate goal of the program is to substantially increase the market availability of R-CFLs suitable for operation in IC/AT recessed downlights. 
Recessed downlights are by far the most popular residential fixture. The U.S. Census Bureau reported that about 21.6 million residential recessed fixtures were sold in 2000. Although precise figures on the number of installed recessed downlight fixtures are not available, we estimate 400 million are installed in residential buildings, with almost all using incandescent light sources. The U.S. Department of Energy, along with numerous utility and market transformation organizations, is interested in promoting R-CFLs selected as part of this program. A significant market opportunity exists for those offerors who produce a product that can successfully compete with incandescent reflector products.

It is anticipated that accepted successful offerors will be awarded a Teaming Agreement with a 12-month period of performance, with an option for an additional 12-month period of performance as agreed to by both parties. Neither DOE nor PNNL intend to directly purchase R-CFLs through the agreements established in this Program. PNNL is acting in a third party role, on behalf of its project partners and other buyers, which will separately and independently make arrangements for any R-CFLs made available through this project.

Successful Offeror(s) under the program shall be responsible for having complied with all applicable Federal and state regulatory and safety standards, regulations, and laws concerning these types of R-CFLs. This includes meeting UL's certification of safety and Federal Communications Commissions standards on electromagnetic interference from fluorescent lighting. All Offerors must have the authority to sell product throughout the United States and its territories.

Successful Offeror(s) shall be required to sign a Teaming Agreement, Enclosure 6, to be included in the program and considered as a supplier of R-CFLs though this program. Program buyers will purchase RCFLs directly from the program suppliers. No price bid is required as part of this solicitation.

PNNL has received expressions of interest from large buyers for the program. These letters of support can be viewed on www.pnl.gov/rlamps/partners2.stm.

Phase 1 Update

In July 2004, two models of R-CFLs manufactured by Philips Lighting Company (SLS R-40 20 watt and EL/A BR30 16 watt) were deemed "winners" of the R-CFL Technology Procurement (Phase 1 of this project). Philips partnered with The Home Depot Supply (the business-to-business division of The Home Depot) to offer these two lamp models via The Home Depot Supply's website (hdsupply.com). The Philips lamps are also available at the R-CFL web site (www.pnl.gov/rlamps) hosted by PNNL, and via other venues. In May 2005, one R-CFL model offered by Feit completed all testing and was also deemed a “winner.” Feit expects to make this model available in Fall 2005.

A total of twelve models representing five manufacturers were submitted in response to the Phase 1 Request for Proposals. Of these, three models successfully completed all testing. For more information, go to www.pnl.gov/rlamps. 


\section{Enclosure 3: Specifications R-CFL Requirements - R-CFL Innovation Competition}

The Offeror shall provide a detailed description of the R-CFLs being submitted as part of their proposal. The following are the minimum technical specifications. Offers that do not meet the minimum mandatory technical specifications shall be determined to be technically non-responsive.

\section{Minimum Mandatory Technical Requirements}

1. Proposed R-CFLs shall comply with ENERGY STAR ${ }^{\circledR}$ Program Requirements for CFLs, Version 3.0. The specifications are listed in Scope, Section D which states "Single based compact fluorescent lamps with integral electronic ballasts and which have a reflector that may be open or closed. The lamp will be intended to replace primarily wide beam incandescent reflector lamps.” ENERGY STAR CFL Specifications can be found at: http://www.energystar.gov/ia/partners/product_specs/program_reqs/cfls_prog_req.pdf

PNNL expects that some R-CFLs, especially newer models, will not have ENERGY STAR approval at the time of proposal in response to this RFP. Lamp models that have not yet received Energy Star approval are eligible for proposal, but will be promoted for sales via this program only after ENERGY STAR approval is attained. For lamp models undergoing ENERGY STAR testing, the Offeror shall provide an expected approval date. Offerors with new lamp models, or existing models that have not been submitted to ENERGY STAR for approval, should indicate 1) submission date (anticipated in some cases), and 2) expected approval date.

2. The Offeror shall self-certify and provide evidence (as specified in the verification column of Table 1) that each proposed R-CFL model meets or exceeds the following technical requirements.

Table 1. Minimum Requirements for R-CFLs for Insulated Ceiling, Airtight fixtures

\begin{tabular}{|l|l|l|}
\hline Feature & \multicolumn{1}{|c|}{ Minimum Requirement } \\
Operating & $\begin{array}{l}\text { Maximum ambient temperature rating of } \\
\text { at least } 50^{\circ} \mathrm{C} \text { for lamps } 16 \text { watts } \\
\text { (measured) and lower, and } 60^{\circ} \mathrm{C} \text { for } \\
\text { lamps greater than } 16 \text { watts (measured). } \\
\text { The Offeror shall provide a maximum } \\
\text { ambient temperature for which the } \\
\text { warranty is valid. }\end{array}$ & $\begin{array}{l}\text { Offeror self-certifies maximum } \\
\text { operating temperature. }\end{array}$ \\
\hline $\begin{array}{l}\text { Size Characteristics } \\
\begin{array}{l}\text { R30-type Products } \\
\text { R40-type Products } \\
\text { (BR, PAR, etc. } \\
\text { products also } \\
\text { qualify) }\end{array}\end{array}$ & $\begin{array}{l}\text { Maximum Overall Length (MOL): } \\
\text { 6.6 inches }\end{array}$ & Offeror self-certifies \\
\hline
\end{tabular}




\begin{tabular}{|c|c|c|}
\hline $\begin{array}{l}\text { Rated Luminous } \\
\text { Flux }\end{array}$ & $\begin{array}{l}\text { Elevated temperature luminous flux: } \\
\text { When operated at } 50 \text { or } 60^{\circ} \mathrm{C} \text {, lamp } \\
\text { shall maintain } 90 \% \text { of } 100 \text { hour } \\
\text { luminous flux achieved while operating } \\
\text { at } 25^{\circ} \mathrm{C} \text {. }\end{array}$ & $\begin{array}{l}\text { Offeror shall provide IESNA LM- } \\
66-00 \text { Electrical and Photometric } \\
\text { Measurements of Single-Ended } \\
\text { Compact Fluorescent Lamps report } \\
\text { with their submittal. ENERGY } \\
\text { STAR currently requires the } \\
\text { average of } 5 \text { base-up/5 base-down. } \\
\text { Offeror may meet the } 600 \text { lumen } \\
\text { minimum with either ENERGY } \\
\text { STAR or all base-up } \\
\text { configurations. } \\
\text { Laboratory tests will be conducted } \\
\text { on lamp samples in a simulated } \\
\text { insulated ceiling environment by } \\
\text { PNNL. (See Section 4.) }\end{array}$ \\
\hline Beam Angle & Maximum $120^{\circ}$ & $\begin{array}{l}\text { Offeror shall specify beam angle in } \\
\text { proposal. Photometric testing of } \\
\text { beam angle in accordance with } \\
\text { LM-20-94 for fluorescent lamps } \\
\text { shall be provided. }\end{array}$ \\
\hline \multicolumn{3}{|c|}{$\begin{array}{l}\text { Exception to these Requirements: Atypical and innovative R-lamp designs will be considered on an } \\
\text { individual basis, provided, 1) there is an overriding and compelling benefit, as described in the } \\
\text { Offeror's proposal and 2) the design is approved by the evaluation committee as being consistent with } \\
\text { the overall purposes and intent of this RFP. }\end{array}$} \\
\hline
\end{tabular}

\section{Responsibilities of the Parties}

The successful Offerors are expected to become suppliers of R-CFLs covered by this solicitation to the buyers participating in this program.

\section{Offeror Contact Information}

Successful offerors are encouraged to provide product brochures and graphics suitable for placement on a promotional web site, which PNNL will maintain. The PNNL web site will provide an overview of the R-CFL Program, a description of the products available, and contact information for the successful offerors.

\section{Program Promotion}

The U.S. Department of Energy and PNNL will promote this program at the national level through news releases and publications and will feature the participating suppliers in these promotional materials. PNNL will develop a web site to promote the winning R-CFL models (see www.pnl.gov/rlamps - the site used to promote the Phase 1 RCFLs). This web site will be promoted as part of the overall outreach and marketing effort. In addition, PNNL will coordinate with utility, market transformation, and other partners to promote the winning lamp models. For examples, see letters of support for Phase 1 at http://www.pnl.gov/rlamps/partners.stm). Letters of support are posted on the Phase 2 page of the program web site.

\section{Reporting}

For the purpose of evaluating the program in saving energy and consumer costs, successful offerors will be required to report the unit volume of sales under this program to PNNL on a quarterly basis. Individual company unit sales information will not be released to the public by PNNL, except in 
aggregate, and specific manufacturer sales will be treated as confidential. The following is an outline of the required information to be delivered to PNNL.

Reporting shall be done via electronic mail to PNNL and shall include the following:

- $\quad$ Number of R-CFLs shipped during the time period, by model.

- Number of R-CFLs sold through this program that were returned for servicing or replacement under warranty.

\section{Acceptance Test}

Twelve (12) samples of each R-lamp model offered shall be included with the proposal for evaluation and testing. These lamps will not be returned to the Offeror.

Lamps will be evaluated against the Reflector CFL Requirements (described in Section 2.0) and will undergo short-term testing by PNNL (described in Section 4.2) to demonstrate compliance with the minimum specifications listed in Table 1. Lamp models that meet the minimum qualifications and are determined to be technically responsive shall be selected for inclusion in the life testing phase of this program. Full life testing is explained in Section 4.3.

Offerors will be required to pay the cost of full life testing, which will be conducted by PNNL or its subcontractors.

Photometric Test Reports

The Offereror shall provide documentation or labeling verifying that the lamps have been tested, listed, and labeled (if applicable) by an organization accredited by the National Voluntary Laboratory Accreditation Program (NVLAP) or the American Association for Laboratory Accreditation (A2LA) as having the capability for testing, listing, and labeling CFLs. These organizations include Underwriters Laboratories (UL), Intertek Testing Services Performance Division (formerly ETL Testing Laboratories), Factory Mutual, and others. Listing and labeling are as defined in the National Electrical Code.

\section{Short-Term Testing}

PNNL will conduct short-term tests as follows: Lamps will initially be operated at $25^{\circ} \mathrm{C}$ to establish the baseline light output corresponding to the rated luminous flux determined under LM-66-00. Lamps will then be operated at $50^{\circ} \mathrm{C}$ (for lamps rated at 16 measured watts or lower) or $60^{\circ} \mathrm{C}$ (for lamps rated at greater than 16 measured watts) to simulate the conditions of the ICAT environment. These readings will be used for determining compliance with the luminous flux requirement listed in Table 1.

\section{Long-Term Testing - Elevated Temperature Life Testing (ETLT)}

Lamp models that meet the minimum requirements listed in Table 1 and are selected based upon the evaluation criteria (see Enclosure 4) will undergo Elevated Temperature Life Testing (ETLT) in a simulated insulated ceiling environment. PNNL will conduct ETLT consisting of a minimum 6,000 hour rated life test in a test apparatus 
capable of maintaining $50^{\circ} \mathrm{C} \pm 10^{\circ} \mathrm{C}$ for lamps 16 watts (rated) and lower, or $60^{\circ} \mathrm{C} \pm 10^{\circ} \mathrm{C}$ for lamps greater than 16 watts (rated) and otherwise following the IESNA LM-65-01 Life Testing of Single-Ended Compact Fluorescent Lamps test procedure.

Lamp models that claim an average rated life greater than 6,000 hours (minimum for ENERGY STAR qualification) must complete life testing equal to their specified rated life. A sample size of ten (10) lamps for each model will be subjected by PNNL to the test ETLT; the remaining 2 lamps submitted with the proposal will be used as extras to cover possible lamp breakage or other needs.

Completion of ETLT is the final requirement for inclusion in this program.

\section{Cost to the Offeror}

Offerors will be responsible for paying the cost of full life (ETLT) testing, which is expected to be approximately \$2,000 per lamp model (\$200 per lamp tested). Advanced payment will be required prior to the testing. PNNL will provide the offeror with quarterly test results for the model(s) they have in testing, as well as a summary of the test results for all models (on an summary basis without manufacturer or model number specified).

\section{Confidentiality}

Test results and other proposal-related information will be treated as business sensitive/confidential and will be shared only with the PNNL proposal evaluation committee and the offeror. Members of the evaluation committee will be required to keep evaluation and testing results confidential.

\section{Substitutions and Additions}

After Teaming Agreements are signed pursuant to this RFP, suppliers may be allowed to offer additional models of R-CFLs and to substitute new models for models previously offered. PNNL will determine whether to permit these additions or substitutions based on whether such additions or substitutions appear to be in the best interests of the buyers, and the supplier's past performance under the agreement (e.g., experience to date with the supplier's product performance, delivery record, and related services). 
Appendix D

\section{R-Lamp Savings Calculator}





\section{Appendix D}

\section{R-lamp Savings Calculator}

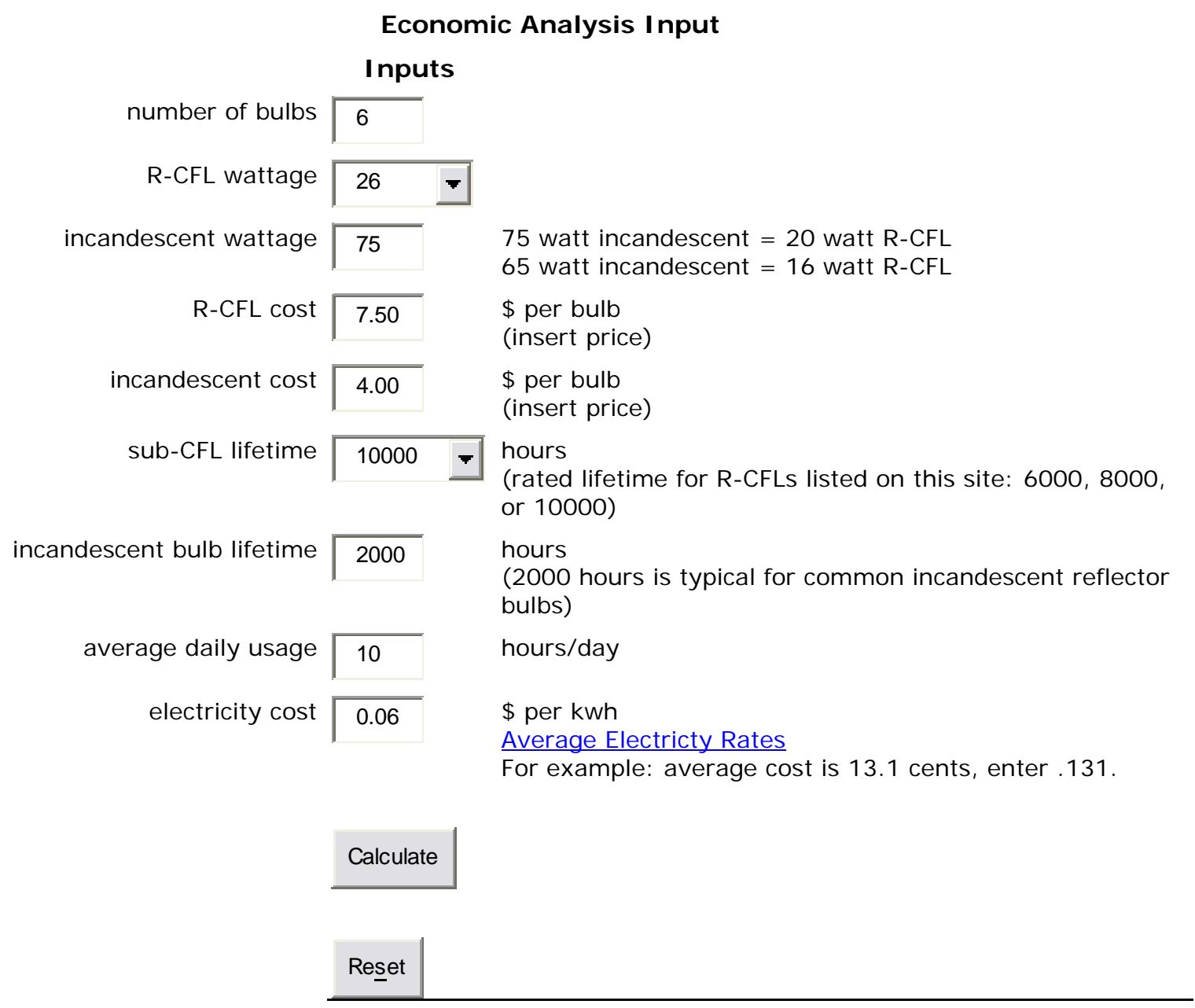


D. 2 


\section{Appendix E}

\section{R-CFL Test Reports}





\section{Phase 2 Batch 1 Elevated Temperature Life Testing (ETLT) -}

Average Rated Life

\section{Number of failures per model}

As of $10281.6+$ on hours

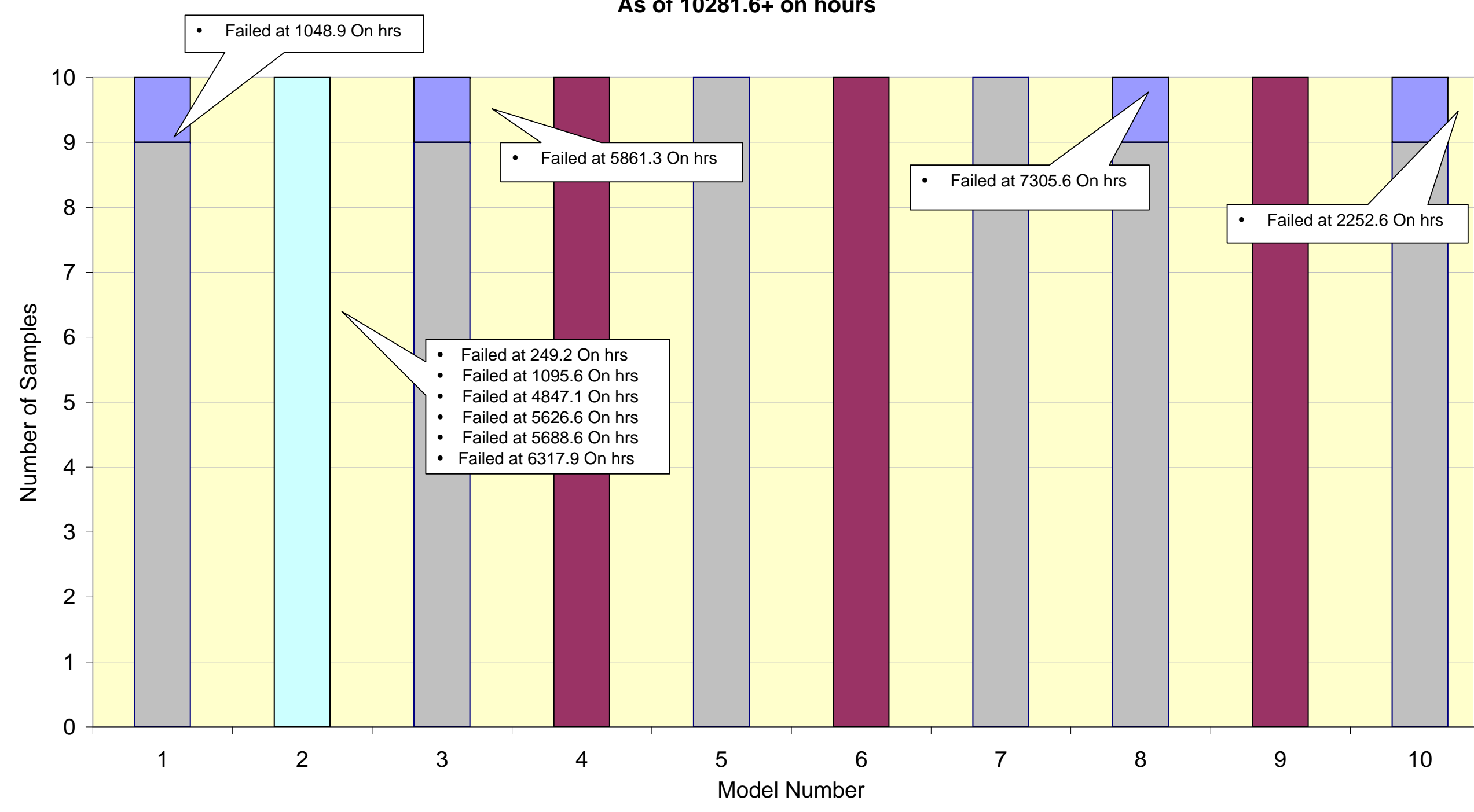

$\begin{array}{ll}\square \text { Still Operating } & \square \text { Failed - Burnout } \\ \square \text { Failed - 1,000 hr lumen maintenance } & \square \text { Failed - Manufacturer Average Rated Life }\end{array}$


Phase 2 Batch 2 Elevated Temperature Life Testing (ETLT) -

Average Rated Life

Number of failures per model

As of 8294.4 on hours

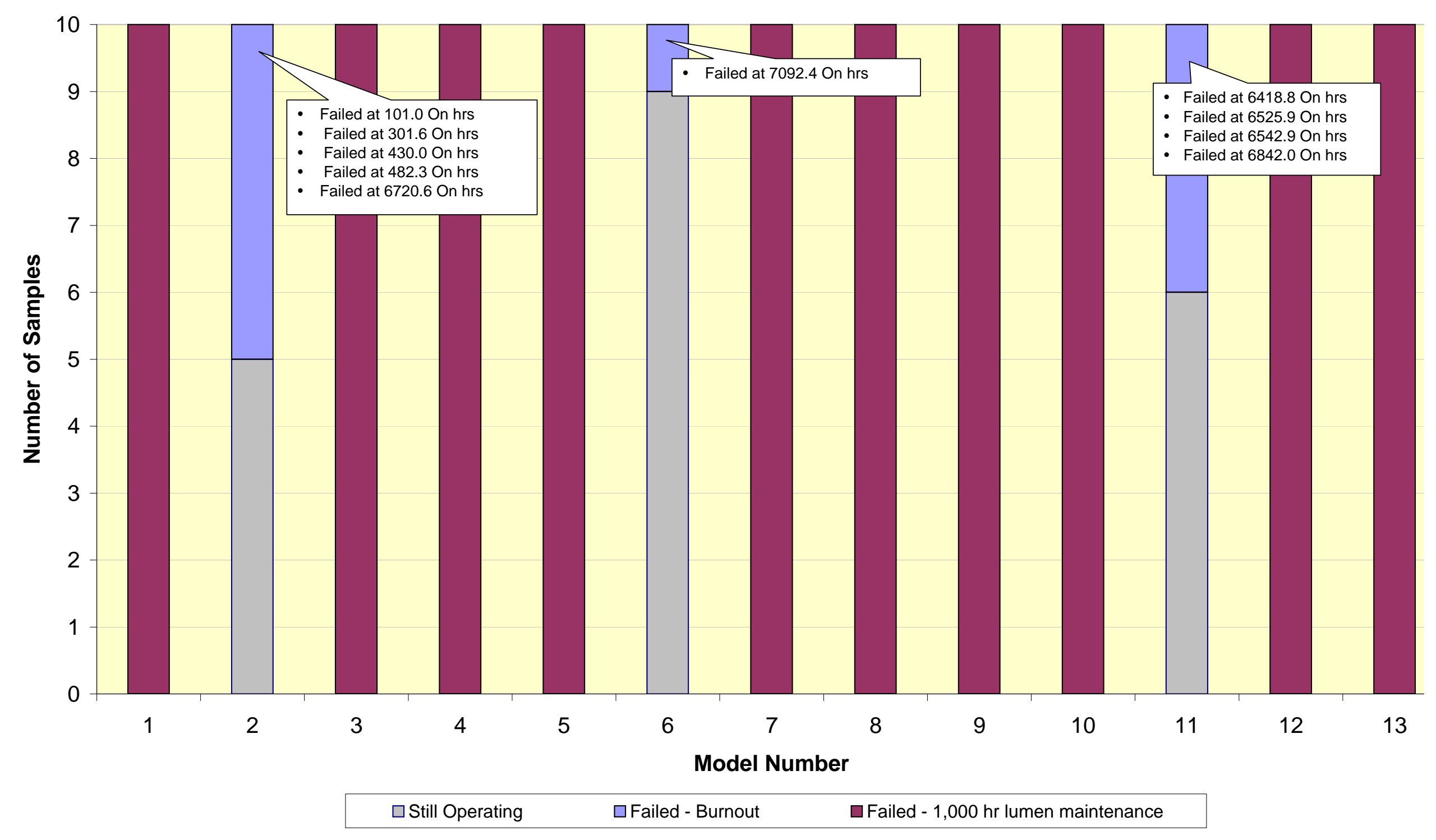


Phase 2 Batch 1 Elevated Temperature Life Testing - Lumen Maintenance Results to Date

10/1/07

Average Lumen Maintenance

\begin{tabular}{|c|c|c|c|c|c|c|c|c|c|c|c|c|c|c|c|c|c|c|c|c|c|}
\hline & & & & & & & & & & & & & & & & & & & & & \\
\hline Lamp Model & Rated Life $^{2}$ & 0.0 & 151.2 & 302.4 & 453.6 & 604.8 & 756.0 & 907.2 & $1000.0^{1}$ & 1209.6 & 1512.0 & 1814.4 & 1814.4 & 2116.8 & 2419.2 & 2721.6 & 3024.0 & 3326.4 & 3628.8 & 3931.2 & 4233.6 \\
\hline \begin{tabular}{|l|} 
Model 1 \\
\end{tabular} & 10000 & $100.0 \%$ & $95.6 \%$ & $92.6 \%$ & $92.3 \%$ & $91.0 \%$ & $90.9 \%$ & $89.5 \%$ & $89.1 \%$ & $88.4 \%$ & $87.1 \%$ & $85.0 \%$ & $85.0 \%$ & $84.7 \%$ & $84.0 \%$ & $83.3 \%$ & $82.0 \%$ & $82.2 \%$ & $81.7 \%$ & $80.5 \%$ & $79.8 \% \%^{3}$ \\
\hline Model 2 & 8000 & $100.0 \%$ & $99.7 \%$ & $99.0 \%$ & $98.9 \%$ & $98.1 \%$ & $97.5 \%$ & $96.3 \%$ & $95.8 \%$ & $94.6 \%$ & $94.3 \%$ & $92.3 \%$ & $92.3 \%$ & $91.5 \%$ & $90.9 \%$ & $90.4 \%$ & $88.6 \%$ & $88.9 \%$ & $88.2 \%$ & $87.4 \%$ & $86.1 \%$ \\
\hline Model 3 & 6000 & $100.0 \%$ & $98.0 \%$ & $97.6 \%$ & $96.6 \%$ & $94.6 \%$ & $93.5 \%$ & $91.7 \%$ & $91.5 \%$ & $91.0 \%$ & $90.3 \%$ & $86.6 \%$ & $86.6 \%$ & $86.4 \%$ & $85.5 \%$ & $84.8 \%$ & $84.6 \%$ & $85.2 \%$ & $83.9 \%$ & $83.3 \%$ & $81.7 \%$ \\
\hline Model 4 & 8000 & $100.0 \%$ & $95.6 \%$ & $92.0 \%$ & $91.5 \%$ & $89.8 \%$ & $88.2 \%$ & $86.4 \%$ & $85.7 \%$ & $84.2 \%$ & $81.8 \%$ & $79.2 \%$ & $79.2 \%$ & $76.6 \%$ & $76.0 \%$ & $73.9 \%$ & $72.0 \%$ & & & & \\
\hline Model 5 & 10000 & $100.0 \%$ & $97.2 \%$ & $96.0 \%$ & $94.8 \%$ & $92.1 \%$ & $91.3 \%$ & $89.2 \%$ & $89.2 \%$ & $89.2 \%$ & $87.9 \%$ & $83.4 \%$ & $83.4 \%$ & $83.3 \%$ & $82.5 \%$ & $81.1 \%$ & $81.1 \%$ & $81.1 \%$ & $80.0 \%$ & $78.9 \%$ & $77.1 \%$ \\
\hline \begin{tabular}{|l|} 
Model 6 \\
\end{tabular} & 8000 & $100.0 \%$ & $95.0 \%$ & $91.6 \%$ & $90.6 \%$ & $88.8 \%$ & $87.6 \%$ & $85.3 \%$ & $85.1 \%$ & $84.7 \%$ & $82.3 \%$ & $78.2 \%$ & $78.2 \%$ & $77.6 \%$ & $76.3 \%$ & $74.8 \%$ & $72.4 \%$ & & & & \\
\hline Model 7 & 10000 & $100.0 \%$ & $95.7 \%$ & $93.2 \%$ & $92.6 \%$ & $91.1 \%$ & $90.5 \%$ & $89.4 \%$ & $88.7 \%$ & $87.0 \%$ & $86.8 \%$ & $85.0 \%$ & $85.0 \%$ & $84.4 \%$ & $84.0 \%$ & $82.9 \%$ & $82.0 \%$ & $82.8 \%$ & $81.6 \%$ & $81.2 \%$ & $80.5 \%$ \\
\hline Model 8 & 8000 & $100.0 \%$ & $98.9 \%$ & $98.6 \%$ & $98.2 \%$ & $97.4 \%$ & $96.9 \%$ & $95.7 \%$ & $95.7 \%$ & $95.7 \%$ & $95.2 \%$ & $92.2 \%$ & $92.2 \%$ & $92.2 \%$ & $91.6 \%$ & $90.5 \%$ & $90.3 \%$ & $90.8 \%$ & $88.5 \%$ & $88.2 \%$ & $87.6 \%$ \\
\hline \begin{tabular}{|l|} 
Model 9 \\
\end{tabular} & 8000 & $100.0 \%$ & $94.4 \%$ & $92.0 \%$ & $89.2 \%$ & $87.6 \%$ & $85.9 \%$ & $83.8 \%$ & $83.3 \%$ & $82.2 \%$ & $80.2 \%$ & $75.8 \%$ & $75.8 \%$ & $74.1 \%$ & $73.7 \%$ & $71.8 \%$ & $71.4 \%$ & & & & \\
\hline Model 10 & 6000 & $100.0 \%$ & $93.8 \%$ & $92.2 \%$ & $91.4 \%$ & $89.7 \%$ & $88.9 \%$ & $87.3 \%$ & $87.3 \%$ & $87.3 \%$ & $86.9 \%$ & $82.9 \%$ & $82.9 \%$ & $82.5 \%$ & $83.3 \%$ & $82.6 \%$ & $81.8 \%$ & $81.8 \%$ & $81.0 \%$ & $80.4 \%$ & $79.3 \%$ \\
\hline & & & & & & & & & & & ON Hrs" & & & & & & & & & & \\
\hline Lamp Model & 4536.0 & $\begin{array}{l}4838.4 \\
\end{array}$ & 5140.8 & 5443.2 & 5745.6 & 6048.0 & 6350.4 & 6652.8 & 6955.2 & 7257.6 & 7560.0 & 7862.4 & 8164.8 & 8467.2 & 8769.6 & 9072.0 & 9374.4 & 9676.8 & 9979.2 & 10281.6 & 10584.0 \\
\hline \begin{tabular}{|l|} 
Model 1 \\
\end{tabular} & $78.9 \%$ & $77.7 \%$ & $77.7 \%$ & $77.0 \%$ & $76.3 \%$ & $76.7 \%$ & $77.2 \%$ & $76.3 \%$ & $75.9 \%$ & $77.1 \%$ & $76.9 \%$ & $76.5 \%$ & $77.7 \%$ & $76.9 \%$ & $76.3 \%$ & $76.6 \%$ & $74.8 \%$ & $74.6 \%$ & $70.0 \%$ & $69.7 \%$ & \\
\hline Model 2 & $83.4 \%$ & $79.9 \%$ & $79.9 \%$ & $79.9 \%$ & $79.9 \%$ & $79.9 \%$ & $79.9 \%$ & $79.9 \%$ & $79.9 \%$ & $79.9 \%$ & $79.9 \%$ & & & & & & & & & & \\
\hline Model 3 & $81.1 \%$ & $80.3 \%$ & $80.5 \%$ & $79.9 \%$ & $79.1 \%$ & $78.9 \%$ & & & & & & & & & & & & & & & \\
\hline \begin{tabular}{|l|} 
Model 4 \\
\end{tabular} & & & & & & & & & & & & & & & & & & & & & \\
\hline Model 5 & $77.2 \%$ & $76.5 \%$ & $76.3 \%$ & $75.4 \%$ & $74.8 \%$ & $75.9 \%$ & $76.1 \%$ & $75.4 \%$ & $75.4 \%$ & $75.7 \%$ & $76.0 \%$ & $75.1 \%$ & $76.7 \%$ & $76.8 \%$ & $76.1 \%$ & $77.1 \%$ & $74.3 \%$ & $74.0 \%$ & $74.2 \%$ & $73.6 \%$ & \\
\hline Model 6 & & & & & & & & & & & & & & & & & & & & & \\
\hline \begin{tabular}{|l|} 
Model 7 \\
\end{tabular} & $79.2 \%$ & $79.1 \%$ & $79.2 \%$ & $78.7 \%$ & $78.2 \%$ & $79.0 \%$ & $78.9 \%$ & $78.4 \%$ & $78.1 \%$ & $78.7 \%$ & $78.6 \%$ & $78.1 \%$ & $79.8 \%$ & $78.5 \%$ & $78.2 \%$ & $78.5 \%$ & $77.0 \%$ & $77.1 \%$ & $76.8 \%$ & $76.9 \%$ & \\
\hline Model 8 & $87.2 \%$ & $86.5 \%$ & $86.2 \%$ & $85.3 \%$ & $84.7 \%$ & $85.6 \%$ & $85.4 \%$ & $84.7 \%$ & $84.5 \%$ & $85.2 \%$ & $85.6 \%$ & $84.8 \%$ & $86.3 \%$ & & & & & & & & \\
\hline Model 9 & & & & & & & & & & & & & & & & & & & & & \\
\hline Model 10 & $79.0 \%$ & $78.3 \%$ & $78.0 \%$ & $77.5 \%$ & $77.2 \%$ & $77.7 \%$ & & & & & & & & & & & & & & & \\
\hline
\end{tabular}

1) 1,000 Hour Lumen Maintenance - ENERGY STAR@ requires that average lumen output measurement of the 10 lamps tested must be greater than $90 \%$ of initial (100 hour) lumen output at 1,000 hours (measurement error of $3 \%$ ). Models in red have failed the test.

2) Lamp Model - 10 samples per lamp model undergo testing. Percentage shown in table is the average for the model at a specific number of "on" hours.

3) $40 \%$ Rated Life Lumen Maintenance - ENERGY STAR $®$ requires that the average of 10 samples tested must be greater than $80 \%$ of initial (100 hour) rating at $40 \%$ of model's rated life (measurement error of $3 \%$ ).

Readings highlighted in blue indicate the model reached $40 \%$ of rated life.

5) Readings highlighted in green indicate that the model has successfully completed ETLT.

Average Lumen Maintenance

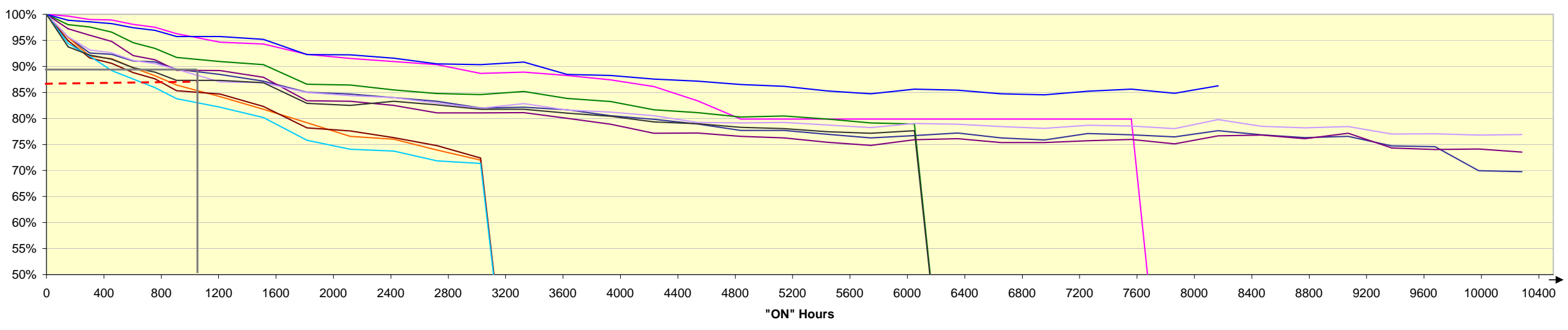

The testing apparatus operates the lamps in an automated cycle of 3 hours "on," 20 minutes "off," for the test duration. Lamps are tested at an ambient temperature of $55^{\circ} \mathrm{C}$

Light intensity for each lamp is measured every 2 weeks throughout the ETLT process to evaluate lumen depreciation over time. 


\section{Phase 2 Batch 2 Elevated Temperature Life Testing - Lumen Maintenance Results to Date}

10/1/07

Average Lumen Maintenance

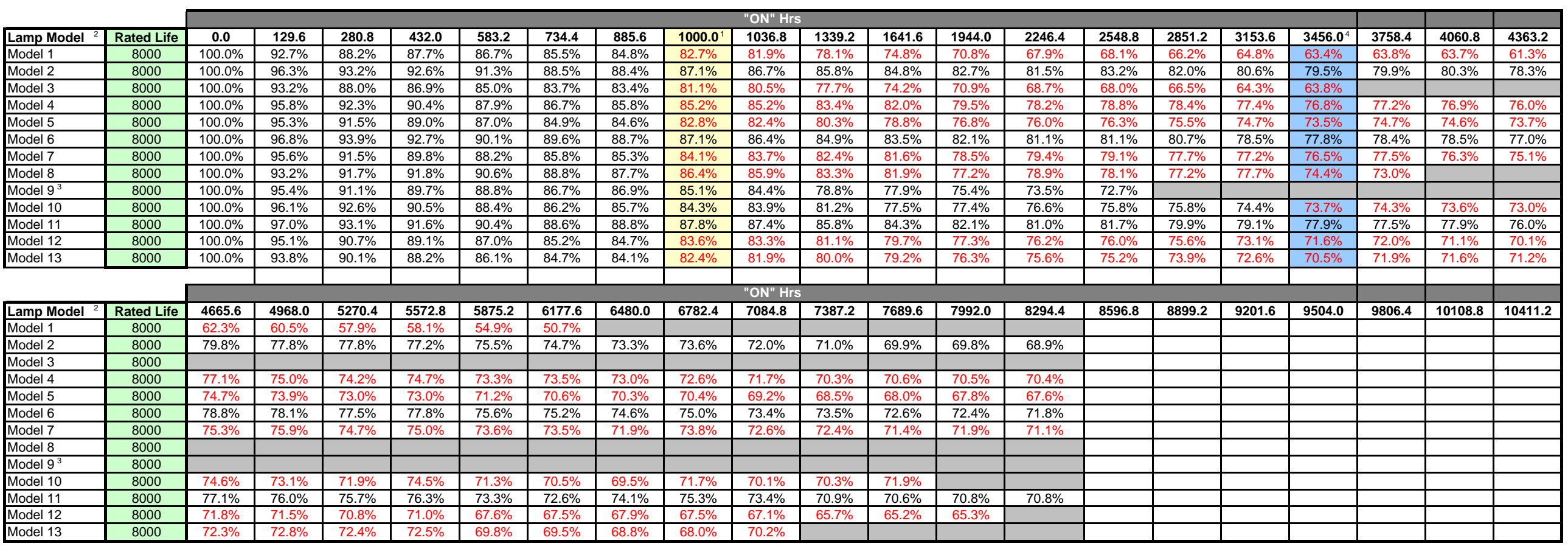

1) 1,000 Hour Lumen Maintenance - ENERGY STAR® requires that average lumen output measurement of the 10 lamps tested must be greater than $90 \%$ of initial (100 hour) lumen output at 1,000 hours (measurement error of $3 \%$ Models in red have failed the test.

2) Lamp Model - 10 samples per lamp model undergo testing. Percentage shown in table is the average for the model at a specific number of "on" hours.

3) Model highlighted ingrey has been terminiated from testing.

4) $40 \%$ Rated Life Lumen Maintenance - ENERGY STAR $®$ requires that the average of 10 samples tested must be greater than $80 \%$ of initial (100 hour) rating at $40 \%$ of model's rated life (measurement error of $3 \%$ ).

Readings highlighted in blue indicate the model reached $40 \%$ of rated life. Models in red have failed the test.

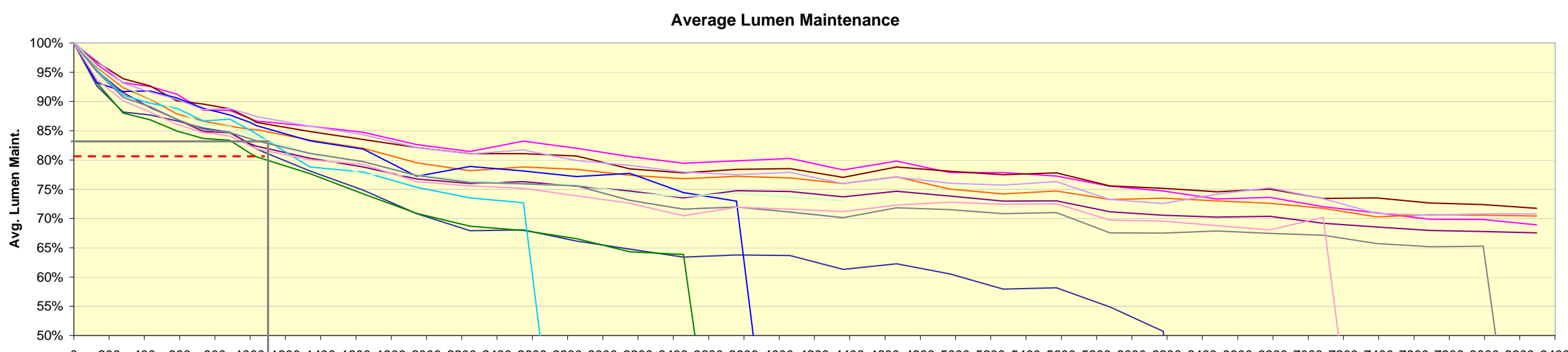

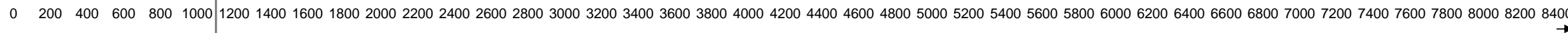
"ON" Hours 
Mautacturer-

$\begin{array}{ll}\text { Lamp Model: } & \text { High Heat Rated R-30 CFL Reflector } \\ \text { Test Facility: } & \text { Luminaire Testing Laboratory; Allentown, }\end{array}$

$\begin{array}{ll}\begin{array}{l}\text { Date Provided: } \\ \text { Rated Life: }\end{array} & 8 / 500 \\ 8000\end{array}$

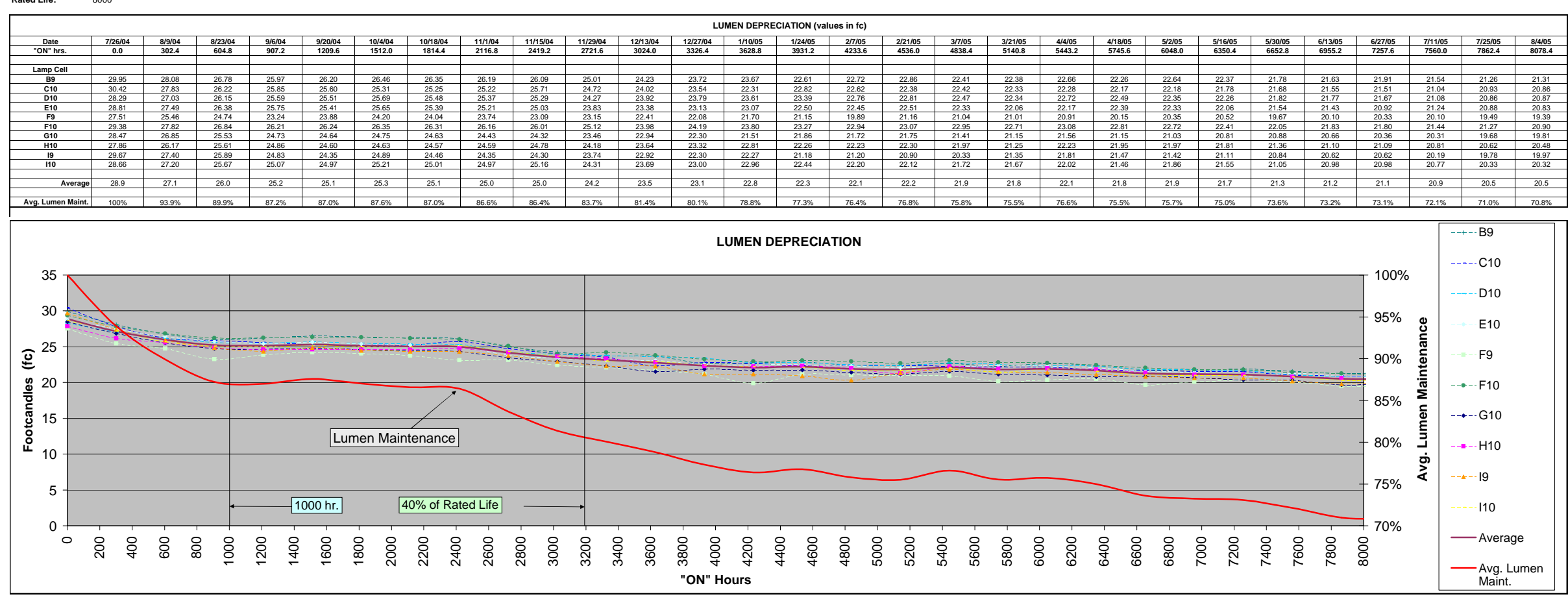




\section{Pacific Northwest National Laboratory}

\section{PHILIPS}

Manufacturer: Philips

Lamp Model: $\quad$ EL/A BR40 20W (EL/A PAR38 20W)

Test Facility: Luminaire Testing Laboratory, Allentown, PA

Date Provided: 6/5/2008

Test Number: 09267

\section{Life and Lumen Maintenance Report}

\begin{tabular}{|c|c|c|c|c|c|c|c|c|c|c|c|c|c|c|c|c|c|c|c|}
\hline & & & & & & & & LUMEN M & NTENAN & (values & & & & & & & & & \\
\hline Date & $1 / 4 / 06$ & $1 / 11 / 06$ & $1 / 18 / 06$ & $1 / 25 / 06$ & $2 / 1 / 06$ & $2 / 8 / 06$ & $2 / 15 / 06$ & $3 / 1 / 06$ & $3 / 15 / 06$ & $3 / 29 / 06$ & $4 / 12 / 06$ & $4 / 26 / 06$ & $5 / 10 / 06$ & $5 / 24 / 06$ & $6 / 7106$ & $6 / 21 / 06$ & $7 / 5 / 06$ & $7 / 19 / 06$ & $8 / 2 / 06$ \\
\hline "ON" hrs. & 0.0 & 151.2 & 302.4 & 453.6 & 604.8 & 756.0 & 907.2 & 1209.6 & 1512.0 & 1814.4 & 2116.8 & 2419.2 & 2721.6 & 3024.0 & 3326.4 & 3628.8 & 3931.2 & 4233.6 & 4536.0 \\
\hline Lamp Cell & & & & & & & & & & & & & & & & & & & \\
\hline $\mathrm{H} 7$ & 40.68 & 40.92 & 40.70 & 40.54 & 40.09 & 39.91 & 38.27 & 37.16 & 37.89 & 37.34 & 37.09 & 36.99 & 36.95 & 36.25 & 36.37 & 35.80 & 35.60 & 35.35 & 34.61 \\
\hline $\mathrm{H} 6$ & 38.50 & 38.43 & 37.55 & 37.38 & 36.76 & 36.68 & 36.15 & 34.83 & 35.45 & 34.42 & 34.59 & 34.57 & 34.10 & 33.86 & 34.16 & 33.50 & 33.61 & 33.20 & 32.83 \\
\hline $\mathrm{H} 5$ & 39.21 & 39.01 & 38.56 & 38.40 & 38.04 & 37.65 & 37.42 & 36.82 & 36.73 & 35.27 & 35.30 & 34.77 & 34.78 & 34.28 & 34.52 & 34.65 & 34.10 & 33.62 & 33.26 \\
\hline $\mathrm{H} 4$ & 40.86 & 40.26 & 40.30 & 40.29 & 40.03 & 39.73 & 39.27 & 38.66 & 38.37 & 37.72 & 37.11 & 36.85 & 37.11 & 36.12 & 36.47 & 36.46 & 36.11 & 35.34 & 35.09 \\
\hline $\mathrm{H} 3$ & 37.22 & 37.90 & 37.06 & 37.50 & 37.47 & 37.52 & 36.95 & 36.70 & 36.21 & 35.12 & 34.89 & 34.60 & 34.45 & 33.69 & 33.96 & 33.78 & 33.16 & 32.45 & 31.93 \\
\hline G3 & 36.71 & 36.75 & 36.30 & 36.29 & 35.83 & 35.72 & 35.54 & 34.98 & 35.10 & 34.69 & 34.61 & 34.10 & 33.97 & 33.66 & 33.50 & 33.73 & 33.43 & 32.72 & 32.12 \\
\hline $\mathrm{F} 3$ & 37.69 & 38.10 & & & & & & & & & & & & & & & & & \\
\hline E2 & 41.41 & 40.71 & 40.24 & 39.93 & 39.74 & 39.58 & 39.27 & 39.18 & 38.51 & 37.94 & 37.41 & 37.28 & 36.90 & 35.87 & 35.77 & 35.42 & 34.73 & 34.46 & 33.48 \\
\hline $\mathrm{D} 2$ & 40.62 & 39.89 & 39.70 & 39.72 & 39.39 & 38.96 & 38.77 & 38.19 & 37.72 & 37.06 & 36.06 & 35.96 & 35.38 & 34.61 & 34.60 & 34.60 & 34.45 & 34.13 & 33.47 \\
\hline $\mathrm{C} 2$ & 41.82 & 41.44 & 41.40 & 41.40 & 40.99 & 40.72 & 40.44 & 39.70 & 39.10 & 38.41 & 38.15 & 37.85 & 37.35 & 36.52 & 36.61 & 35.74 & 35.52 & 34.82 & 29.67 \\
\hline Average & 39.5 & 39.3 & 39.1 & 39.1 & 38.7 & 38.5 & 38.0 & 37.4 & 37.2 & 36.4 & 36.1 & 35.9 & 35.7 & 35.0 & 35.1 & 34.9 & 34.5 & 34.0 & 32.9 \\
\hline & & & & & & & & & & & & & & & & & & & \\
\hline $\begin{array}{r}\text { verage Lumen } \\
\text { Maint. }\end{array}$ & $100.0 \%$ & $99.7 \%$ & $99.0 \%$ & $98.9 \%$ & $98.1 \%$ & $97.5 \%$ & $96.3 \%$ & $94.6 \%$ & $94.3 \%$ & $92.3 \%$ & $91.5 \%$ & $90.9 \%$ & $90.4 \%$ & $88.6 \%$ & $88.9 \%$ & $88.2 \%$ & $87.4 \%$ & $86.1 \%$ & $83.4 \%$ \\
\hline
\end{tabular}

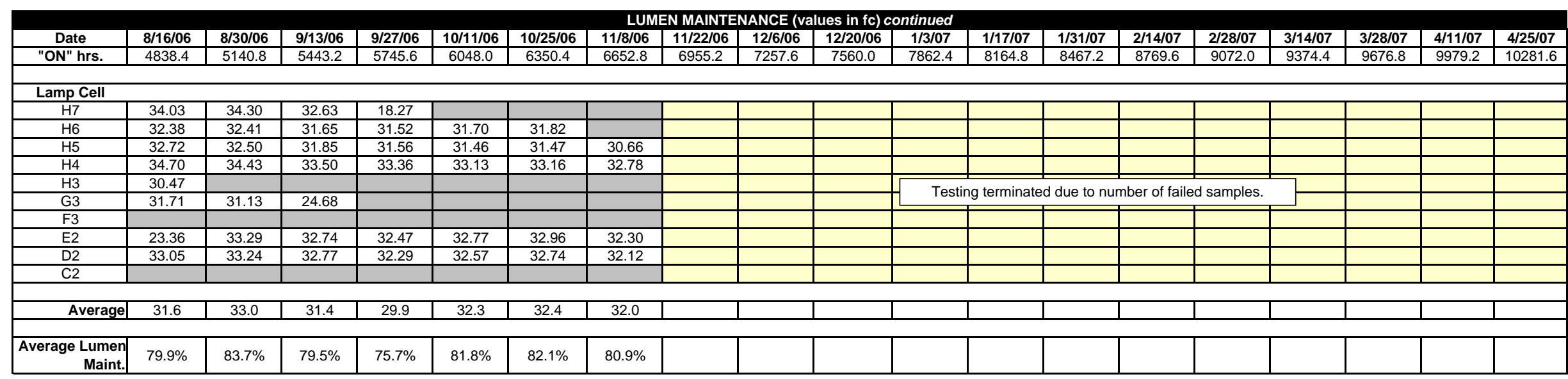

Comments: Lamp Cell F3 failed on 1/15/06 at $249.2 \mathrm{hrs}$ Lamp Cell C2 failed at 8/6/06 at $4445.3 \mathrm{hrs}$ Lamp Cell H3 failed on 8/20/06 at 4847.1 hrs Lamp Cell G3 failed on 9/25/06 sy 5626.6 hrs
Lamp Cell H7 failed on 9/28/08 at 5688.6 hrs Lamp Cell H6 failed on 10/29/06 at $6317.9 \mathrm{hrs}$
Rated Life

$1000 \mathrm{hr}$.

$40 \%$ of Rated Lif $8.79 \%$ 


\section{Pacific Northwest National Laboratory}

\section{PHILIPS}

Manufacturer: Philips

Lamp Model: EL/A BR40 20W (EL/A PAR38 20W)

Test Facility: Luminaire Testing Laboratory, Allentown, PA

Date Provided: 6/5/2008

Individual Lamp Illuminance and Life
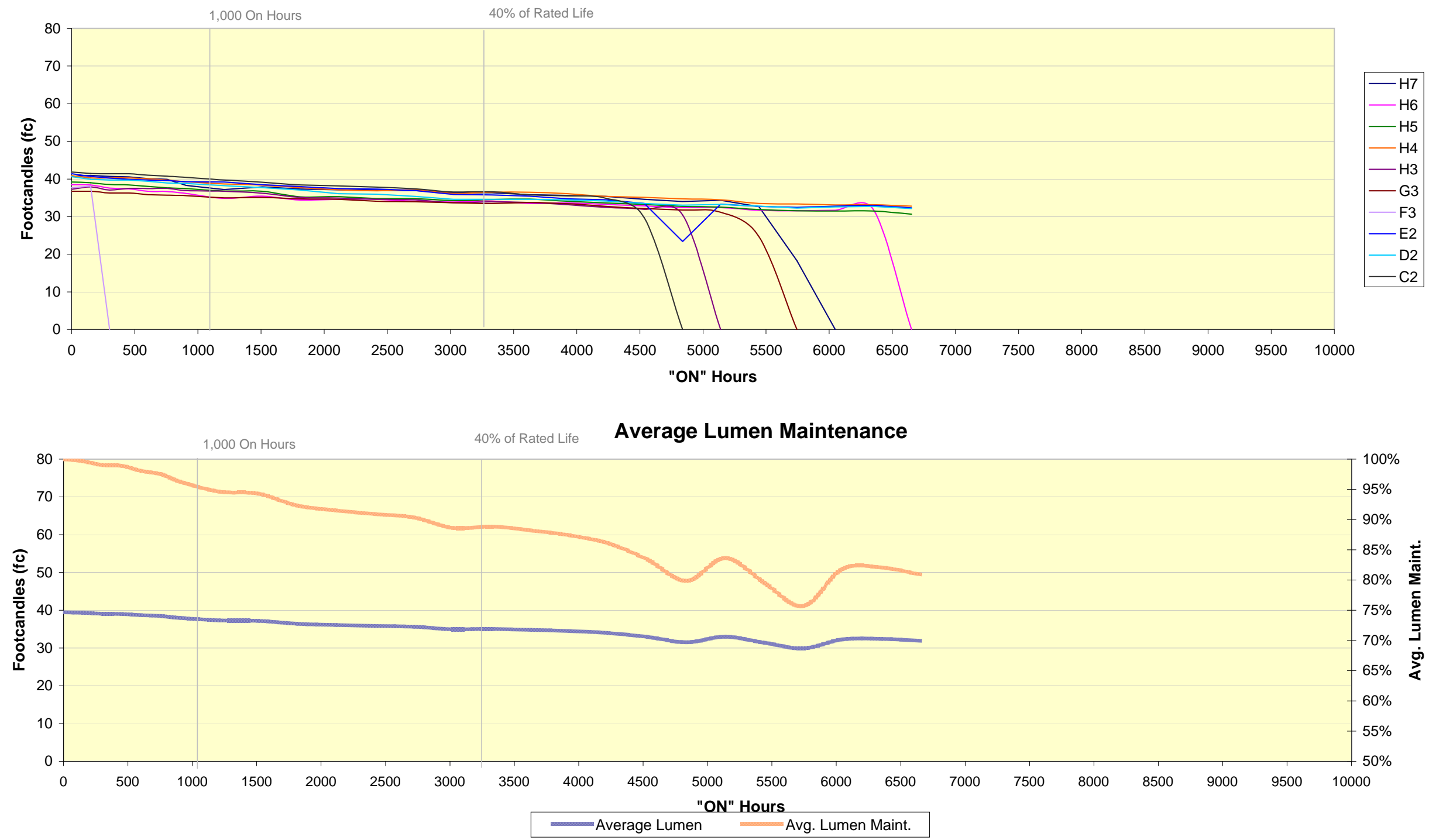


\section{Pacific Northwest National Laboratory}

\section{PHILIPS}

Manufacturer: Philips

Lamp Model: $\quad$ EL/A R40 23W (EL/A PAR38 23W)

Test Facility: Luminaire Testing Laboratory, Allentown, PA

Date Provided: 6/5/2008

\section{Life and Lumen Maintenance Report}

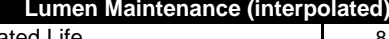

Rated Lif

$1000 \mathrm{hr}$.

\begin{tabular}{ll|l}
$40 \%$ of Rated Life & 3200 & $80.39 \%$ \\
\hline
\end{tabular}

\begin{tabular}{|c|c|c|c|c|c|c|c|c|c|c|c|c|c|c|c|c|c|c|c|}
\hline & & & & & & & & UMEN N & NTENAN & (values & fc) & & & & & & & & \\
\hline Date & $6 / 15 / 06$ & $6 / 21 / 06$ & $6 / 28 / 06$ & $7 / 5 / 06$ & $7 / 12 / 06$ & $7 / 19 / 06$ & $7 / 26 / 06$ & $8 / 2 / 06$ & $8 / 16 / 06$ & $8 / 30 / 06$ & $9 / 13 / 06$ & $9 / 27 / 06$ & $10 / 11 / 06$ & $10 / 25 / 06$ & $11 / 8 / 06$ & 11/22/06 & $12 / 6 / 06$ & $12 / 20 / 06$ & $1 / 3 / 07$ \\
\hline "ON" hrs. & 0.0 & 129.6 & 280.8 & 432.0 & 583.2 & 734.4 & 885.6 & 1036.8 & 1339.2 & 1641.6 & 1944.0 & 2246.4 & 2548.8 & 2851.2 & 3153.6 & 3456.0 & $\begin{array}{l}3758.4 \\
\end{array}$ & 4060.8 & 4363.2 \\
\hline \multicolumn{20}{|l|}{ Lamp Cell } \\
\hline D7 & 53.42 & 52.09 & 50.36 & 50.07 & 49.13 & 48.32 & 48.14 & 45.99 & 45.60 & 45.52 & 44.71 & 44.47 & 44.73 & 44.03 & 43.76 & 43.10 & 43.36 & 43.16 & 42.18 \\
\hline G4 & 56.51 & 53.65 & 53.54 & 52.20 & 51.33 & 50.50 & 50.20 & 49.17 & 47.91 & 48.51 & 47.49 & 46.89 & 48.01 & 47.36 & 46.99 & 45.10 & 47.31 & 47.12 & 45.54 \\
\hline E8 & 53.00 & 47.53 & 48.44 & 47.59 & 46.58 & 45.13 & 43.91 & 42.20 & 42.98 & 41.33 & 40.86 & 38.91 & 41.69 & 40.41 & 40.13 & 40.23 & 39.21 & 39.86 & 39.56 \\
\hline E7 & 53.72 & 51.57 & 49.38 & 49.01 & & & & & & & & & & & & & & & \\
\hline G5 & 54.50 & 53.64 & 52.77 & 50.08 & 50.50 & 47.20 & 48.05 & 48.81 & 47.86 & 47.53 & 45.18 & 44.54 & 45.87 & 44.80 & 42.41 & 42.76 & 43.46 & 44.88 & 42.71 \\
\hline C10 & 55.83 & 54.17 & & & & & & & & & & & & & & & & & \\
\hline D10 & 51.86 & 51.56 & 47.13 & & & & & & & & & & & & & & & & \\
\hline E10 & 53.50 & & & & & & & & & & & & & & & & & & \\
\hline B10 & 54.21 & 52.47 & 51.11 & 50.75 & 49.60 & 47.84 & 47.96 & 47.20 & 46.64 & 46.13 & 45.20 & 44.49 & 44.50 & 44.72 & 43.56 & 42.84 & 42.81 & 42.52 & 42.45 \\
\hline D8 & 57.64 & 55.02 & 52.90 & 52.74 & 50.75 & 49.95 & 50.43 & 49.51 & 48.97 & 47.61 & 46.35 & 46.60 & 46.90 & 46.32 & 46.20 & 45.33 & 44.52 & 44.44 & 43.19 \\
\hline Average & 54.4 & 52.4 & 50.7 & 50.3 & 49.6 & 48.2 & 48.1 & 47.1 & 46.7 & 46.1 & 45.0 & 44.3 & 45.3 & 44.6 & 43.8 & 43.2 & 43.4 & 43.7 & 42.6 \\
\hline & & & & & & & & & & & & & & & & & & & \\
\hline $\begin{array}{l}\text { Average Lumen } \\
\text { Maint. }\end{array}$ & $100.0 \%$ & $96.3 \%$ & $93.2 \%$ & $92.6 \%$ & $91.3 \%$ & $88.5 \%$ & $88.4 \%$ & $86.7 \%$ & $85.8 \%$ & $84.8 \%$ & $82.7 \%$ & $81.5 \%$ & $83.2 \%$ & $82.0 \%$ & $80.6 \%$ & $79.5 \%$ & $79.9 \%$ & $80.3 \%$ & $78.3 \%$ \\
\hline
\end{tabular}

\begin{tabular}{|c|c|c|c|c|c|c|c|c|c|c|c|c|c|c|c|c|c|c|c|}
\hline \multicolumn{20}{|c|}{$\begin{array}{ll}\text { LUMEN MAINTENANCE (values in fc) continued } \\
\end{array}$} \\
\hline Date & $1 / 17 / 07$ & $1 / 31 / 07$ & $2 / 14 / 07$ & $2 / 28 / 07$ & $3 / 14 / 07$ & $3 / 28 / 07$ & $4 / 11 / 07$ & $4 / 25 / 07$ & $5 / 9 / 07$ & $5 / 23 / 07$ & $6 / 6 / 07$ & $6 / 20 / 07$ & $7 / 4 / 07$ & $7 / 18 / 07$ & $8 / 1 / 07$ & $8 / 15 / 07$ & $8 / 29 / 07$ & $9 / 12 / 07$ & 9/26/07 \\
\hline "ON" hrs. & 4665.6 & 4968.0 & 5270.4 & 5572.8 & 5875.2 & 6177.6 & 6480.0 & 6782.4 & 7084.8 & 7387.2 & 7689.6 & 7992.0 & 8294.4 & 8596.8 & 8899.2 & 9201.6 & 9504.0 & 9806.4 & 10108.8 \\
\hline \multicolumn{20}{|l|}{ Lamp Cell } \\
\hline D7 & 42.68 & 42.43 & 41.64 & 41.21 & 39.95 & 40.19 & 39.47 & 39.81 & 38.24 & 37.64 & 37.38 & 37.32 & 37.02 & & & & & & \\
\hline G4 & 46.71 & 45.82 & 45.21 & 44.66 & 43.95 & 43.70 & 41.21 & 41.38 & 42.22 & 41.43 & 41.12 & 41.01 & 39.93 & & & & & & \\
\hline E8 & 39.82 & 37.22 & 37.10 & 36.84 & 38.04 & 35.72 & 36.23 & 36.76 & 36.48 & 35.60 & 34.73 & 34.68 & 34.62 & & & & & & \\
\hline E7 & & & & & & & & & & & & & & & & & & & \\
\hline G5 & 44.05 & 43.34 & 43.23 & 43.07 & 42.21 & 41.97 & 41.15 & 41.37 & 40.41 & 39.82 & 38.84 & 38.96 & 38.41 & & \multirow{2}{*}{\multicolumn{4}{|c|}{ Completed 8000 hours }} & \\
\hline C10 & & & & & & & & & & & & & & & & & & & \\
\hline \multicolumn{20}{|l|}{ D10 } \\
\hline \multicolumn{20}{|l|}{ E10 } \\
\hline B10 & 42.62 & 41.50 & 43.04 & 42.79 & 41.59 & 41.22 & 40.50 & 40.49 & 38.47 & 38.60 & 37.99 & 37.97 & 37.48 & & & & & & \\
\hline D8 & 44.65 & 43.74 & 43.87 & 43.56 & 40.70 & 41.01 & 40.77 & 40.51 & & & & & & & & & & & \\
\hline Average & 434 & 423 & 423 & 420 & 411 & 406 & 399 & 401 & 392 & 386 & 380 & 380 & 375 & & & & & & \\
\hline & & & & & & & & & & & & & & & & & & & \\
\hline $\begin{array}{r}\text { Average Lumen } \\
\text { Maint. }\end{array}$ & $79.8 \%$ & $77.8 \%$ & $77.8 \%$ & $77.2 \%$ & $75.5 \%$ & $74.7 \%$ & $73.3 \%$ & $73.6 \%$ & $72.0 \%$ & $71.0 \%$ & $69.9 \%$ & $69.8 \%$ & $68.9 \%$ & & & & & & \\
\hline
\end{tabular}

Comments: Lamp Cell E10 failed on 6/19/06 at $101.0 \mathrm{hrs}$ Lamp Cell C10 failed on 6/29/06 at $301.6 \mathrm{hrs}$ Lamp Cell D10 failed on 7/5/06 at 430 his
Lamp Cell E7 failed on 7/7/06 at $482.3 \mathrm{hrs}$

Lamp Cell D8 failed on 4/30/2007 at $6820.6 \mathrm{hrs}$ 


\section{$\underset{\text { Pperated by Battelle for the U.S. Department of Energy }}{\text { Pacific Nory }}$}

\section{PHILIPS}

\section{Manufacturer: Philips}

Lamp Model: $\quad$ EL/A R40 23W (EL/A PAR38 23W)

Test Facility: Luminaire Testing Laboratory, Allentown, PA

6/5/2008

Individual Lamp Illuminance and Life

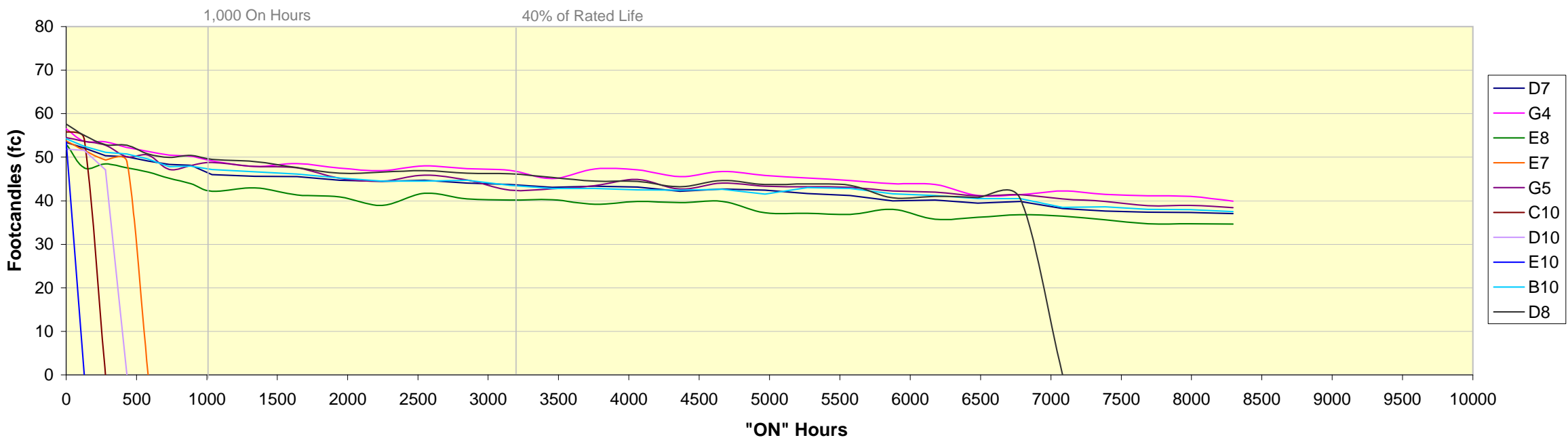

\section{Average Lumen Maintenance}

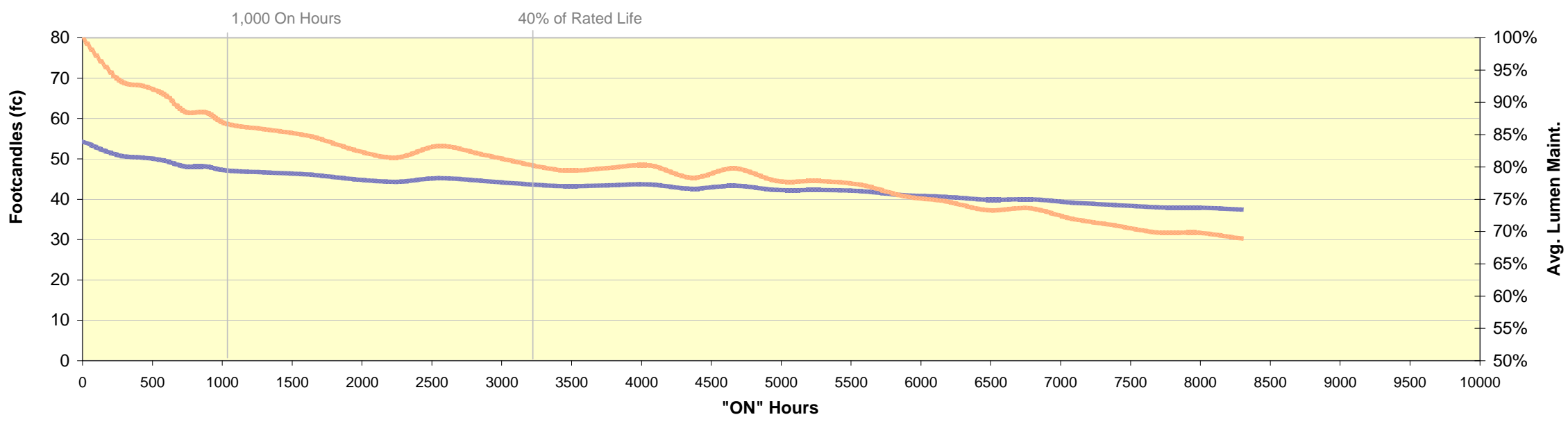




\section{Life and Lumen Depreciation Report}

\begin{tabular}{|c|c|c|c|c|c|c|c|c|c|c|c|c|c|c|c|c|c|c|}
\hline $\begin{array}{l}\text { Maufacturer: } \\
\text { Lamp Model: } \\
\text { Test Facility: } \\
\text { Date Provided: } \\
\text { Initial Test Start Date }\end{array}$ & $\begin{array}{l}\text { Philips } \\
\text { EL/A BR-3 } \\
\text { Luminaire } \\
\text { 1/25/05 } \\
\text { 9/3/03 }\end{array}$ & $\begin{array}{l}30 \\
\text { Testing Le }\end{array}$ & aboratory, & Allentown, & PA & & & & & & & & & & & & & \\
\hline $\begin{array}{l}\text { Lumen Depreciation @ } \\
1000 \text { hrs (interpolated) }\end{array}$ & 27.35 & $7.2 \%$ & & & & & & & & & & & & & & & & \\
\hline $\begin{array}{l}\text { Lumen Maintenance @ } \\
40 \% \text { of Rated Life } \\
\text { (interpolated) }\end{array}$ & 24.41 & $82.8 \%$ & & & & & & & & & & & & & & & & \\
\hline $\begin{array}{l}\text { Reading Date } \\
\text { "ON"Hours }\end{array}$ & \begin{tabular}{|c|}
$6 / 14 / 04$ \\
0.0 \\
\end{tabular} & \begin{tabular}{|l|}
$6 / 28 / 04$ \\
302.4 \\
\end{tabular} & $\begin{array}{l}7 / 12 / 04 \\
604.8 \\
\end{array}$ & \begin{tabular}{|c|}
$\mathbf{1 0 / 2 0 / 0 3}$ \\
1015.2 \\
\end{tabular} & \begin{tabular}{|l|}
$11 / 3 / 03$ \\
1317.6 \\
\end{tabular} & \begin{tabular}{|c|}
$11 / 17 / 03$ \\
1620.0 \\
\end{tabular} & \begin{tabular}{|l|}
$12 / 1 / 03$ \\
1922.4 \\
\end{tabular} & \begin{tabular}{|c|}
$12 / 15 / 03$ \\
2224.8 \\
\end{tabular} & \begin{tabular}{|c|}
$12 / 29 / 03$ \\
2527.2 \\
\end{tabular} & \begin{tabular}{|c|}
$1 / 12 / 04$ \\
2829.6 \\
\end{tabular} & $\begin{array}{l}1 / 26 / 04 \\
3132.0\end{array}$ & $\begin{array}{l}2 / 9 / 04 \\
3434.4\end{array}$ & \begin{tabular}{|l|}
$2 / 23 / 04$ \\
3736.8 \\
\end{tabular} & \begin{tabular}{|l|}
$3 / 8 / 04$ \\
4039.2 \\
\end{tabular} & \begin{tabular}{|l|}
$3 / 22 / 04$ \\
4341.6
\end{tabular} & $\begin{array}{l}4 / 5 / 04 \\
4644.0\end{array}$ & \begin{tabular}{|l|}
$4 / 19 / 04$ \\
4946.4
\end{tabular} & $\begin{array}{l}5 / 3 / 04 \\
5248.8 \\
\end{array}$ \\
\hline B9 & 29.0 & 27.2 & 26.1 & 26.5 & 25.9 & 24.9 & 24.6 & 24.3 & 24.2 & 23.8 & 24.4 & 24.5 & 24.3 & 23.8 & 23.5 & 23.3 & 23.1 & 23.0 \\
\hline $\mathrm{C} 10$ & 25.9 & 25.2 & 24.9 & 27.0 & 26.7 & 26.0 & 25.7 & 25.3 & 25.1 & 24.7 & 24.9 & 25.0 & 24.7 & 24.7 & 24.2 & 24.0 & 23.6 & 23.6 \\
\hline D10 & 26.1 & 24.2 & 23.8 & 27.8 & 27.7 & 26.5 & 26.6 & 26.2 & 25.7 & 25.6 & 24.8 & 25.8 & 25.6 & 25.4 & 24.9 & 24.5 & 24.5 & 24.4 \\
\hline E10 & 25.9 & 24.3 & 23.9 & 27.5 & 27.0 & 26.0 & 25.8 & 25.4 & 25.6 & 25.5 & 24.9 & 25.0 & 24.7 & 24.5 & 24.1 & 23.8 & 23.5 & 23.5 \\
\hline F9 & 27.5 & 26.1 & 25.7 & 27.4 & 27.1 & 26.0 & 25.7 & 25.3 & 25.0 & 25.1 & 24.9 & 25.0 & 24.7 & 24.3 & 24.1 & 23.7 & 23.4 & 23.3 \\
\hline F10 & 28.2 & 26.8 & 26.3 & 26.2 & 26.0 & 25.3 & 25.0 & 25.0 & 25.3 & 25.1 & 24.5 & 24.8 & 24.5 & 24.3 & 23.7 & 23.5 & 23.6 & 23.5 \\
\hline G10 & 27.0 & 25.6 & 25.2 & 27.3 & 26.9 & 26.1 & 25.8 & 25.3 & 25.1 & 24.9 & \begin{tabular}{|l|}
24.3 \\
\end{tabular} & 24.5 & 24.0 & 23.0 & 22.8 & 22.1 & 22.9 & 22.8 \\
\hline $\mathrm{H} 10$ & 27.3 & 25.8 & 25.2 & 26.0 & 25.8 & 24.9 & 24.8 & 24.1 & 23.8 & 23.4 & 22.9 & 23.0 & 22.4 & 22.1 & 21.8 & 21.7 & 21.9 & 22.1 \\
\hline 19 & 28.0 & 26.4 & 25.4 & 26.2 & 25.4 & 24.3 & 25.0 & 24.6 & 24.7 & 24.6 & 24.0 & 24.3 & 24.6 & 24.1 & 23.7 & 23.6 & 23.3 & 23.4 \\
\hline 110 & 27.0 & 25.4 & 24.9 & & & & & & & & & & & & & & & \\
\hline Initial Test (avg.) & & & & 26.9 & 26.5 & 25.6 & 25.5 & 25.1 & 24.9 & 24.7 & 24.4 & 24.7 & 24.4 & 24.0 & 23.6 & 23.3 & 23.3 & 23.3 \\
\hline Supplemental Test (avg.) & 27.2 & 25.7 & 25.1 & 24.6 & & & & & & & & & & & & & & \\
\hline Supplemental+Curve-fit & 29.5 & 28.1 & 27.4 & 26.8 & & & & & & & & & & & & & & \\
\hline Linear-fit to Initial Test & 27.2 & 26.9 & 26.7 & 26.3 & 26.1 & 25.9 & 25.6 & 25.4 & 25.1 & 24.9 & 24.6 & 24.4 & 24.2 & 23.9 & 23.7 & 23.4 & 23.2 & 23.0 \\
\hline Curve-fit & 29.5 & 28.1 & 27.4 & 26.8 & 26.5 & 25.6 & 25.5 & 25.1 & 24.9 & 24.7 & 24.4 & 24.7 & 24.4 & 24.0 & 23.6 & 23.3 & 23.3 & 23.3 \\
\hline Lumen Depreciation & $0 \%$ & $5 \%$ & $7 \%$ & $9 \%$ & $10 \%$ & $13 \%$ & $14 \%$ & $15 \%$ & $15 \%$ & $16 \%$ & $17 \%$ & $16 \%$ & $17 \%$ & $18 \%$ & $20 \%$ & $21 \%$ & $21 \%$ & $21 \%$ \\
\hline
\end{tabular}

\begin{tabular}{|c|c|c|c|c|c|c|c|c|c|c|c|c|c|c|c|c|c|}
\hline $\begin{array}{l}\text { Reading Date } \\
\text { "ON"Hours }\end{array}$ & \begin{tabular}{|l|}
$5 / 17 / 04$ \\
5551.2
\end{tabular} & \begin{tabular}{|l|}
$5 / 31 / 04$ \\
5853.6
\end{tabular} & \begin{tabular}{|l|}
$6 / 14 / 04$ \\
6156.0
\end{tabular} & $\begin{array}{l}6 / 28 / 04 \\
6458.4\end{array}$ & \begin{tabular}{|l|}
$7 / 12 / 04$ \\
6760.8 \\
\end{tabular} & \begin{tabular}{|l|}
$7 / 26 / 04$ \\
7063.2 \\
\end{tabular} & \begin{tabular}{|l|}
$8 / 9 / 04$ \\
7365.6
\end{tabular} & \begin{tabular}{|l|}
$8 / 23 / 04$ \\
7668.0
\end{tabular} & $\begin{array}{l}9 / 6 / 04 \\
7970.4\end{array}$ & \begin{tabular}{|l|}
$9 / 20 / 04$ \\
8272.8
\end{tabular} & $\begin{array}{l}10 / 4 / 04 \\
8575.2\end{array}$ & \begin{tabular}{|c|}
$10 / 18 / 04$ \\
8877.6 \\
\end{tabular} & \begin{tabular}{|l|}
$11 / 1 / 04$ \\
9180.0
\end{tabular} & \begin{tabular}{|c|}
$11 / 15 / 04$ \\
9482.4 \\
\end{tabular} & \begin{tabular}{|c|}
$11 / 29 / 04$ \\
9784.8 \\
\end{tabular} & \begin{tabular}{|l|}
$12 / 13 / 04$ \\
10087.2 \\
\end{tabular} & \begin{tabular}{|l|}
$12 / 27 / 04$ \\
10389.6 \\
\end{tabular} \\
\hline B9 & 22.5 & 22.5 & 21.8 & 21.9 & 21.7 & 21.6 & 21.4 & 20.8 & 20.7 & 20.6 & 20.9 & 20.4 & 20.6 & 20.6 & 19.9 & 19.4 & 19.1 \\
\hline C10 & 23.1 & 22.7 & 22.2 & 21.9 & 21.7 & 21.5 & 21.2 & 20.7 & 20.3 & 20.1 & 20.9 & 20.2 & 19.9 & 19.6 & 18.5 & & \\
\hline D10 & 24.1 & 24.0 & 23.3 & 23.0 & 22.9 & 22.8 & 22.4 & 22.1 & 21.9 & 21.9 & 22.1 & 21.9 & 21.9 & 21.7 & 21.0 & 20.4 & 20.2 \\
\hline E10 & 23.0 & 22.9 & 22.4 & 22.3 & 22.0 & 21.9 & 21.5 & 21.1 & 20.9 & 20.9 & 21.2 & 21.0 & 20.6 & 20.7 & 19.9 & 19.5 & 19.1 \\
\hline F9 & 23.0 & 22.7 & 22.2 & 21.9 & 21.6 & 21.3 & 21.1 & 20.7 & 20.1 & 20.0 & 20.1 & 19.9 & 19.6 & 19.3 & 18.7 & 18.1 & 17.5 \\
\hline $\mathrm{F} 10$ & 23.1 & 22.9 & 22.4 & 22.2 & 21.8 & 21.5 & 21.3 & 20.9 & 20.4 & 20.4 & 20.4 & 20.0 & 19.8 & 19.9 & 19.2 & 18.8 & 18.4 \\
\hline G10 & 22.9 & 22.6 & 21.9 & 21.9 & 21.4 & 21.2 & 21.0 & 20.5 & 20.0 & 19.9 & 20.0 & 19.8 & 19.4 & 19.1 & 18.3 & \begin{tabular}{ll|}
17.8 \\
\end{tabular} & \\
\hline $\mathrm{H} 10$ & 21.8 & 21.6 & 21.1 & 20.7 & 20.6 & 20.3 & 20.2 & 19.7 & 19.4 & 19.2 & 19.4 & 19.3 & 18.4 & 18.3 & 17.7 & 17.2 & 16.7 \\
\hline 19 & 23.0 & 22.8 & 22.3 & 22.0 & 21.7 & 21.5 & $\begin{array}{l}21.3 \\
\end{array}$ & 20.9 & 20.6 & 20.5 & 20.7 & \begin{tabular}{|l|l|}
20. \\
\end{tabular} & 20.1 & 20.3 & 19.7 & $\begin{array}{l}19.3 \\
\end{array}$ & 18.8 \\
\hline 110 & & & & & & & & & & & & & & & & & \\
\hline $\begin{array}{l}\text { Initial Test (avg.) } \\
\text { Supplemental Test (avg.) }\end{array}$ & 22.9 & 22.7 & 22.2 & 22.0 & 21.7 & 21.5 & 21.3 & 20.8 & 20.5 & 20.4 & 20.6 & 20.3 & 20.0 & 19.9 & 19.2 & 18.8 & 18 \\
\hline uppl & & & & & & & & & & & & & & & & & \\
\hline Linear-fit to Initial Test & 22.7 & 22.5 & 22.2 & 22.0 & 21.7 & 21.5 & 21.3 & 21.0 & 20.8 & 20.5 & 20.3 & 20.1 & 19.8 & 19.6 & 19.3 & 19.1 & 18 \\
\hline Curve-fit & 22.9 & 22.7 & 22.2 & 22.0 & 21.7 & 21.5 & 21.3 & 20.8 & 20.5 & 20.4 & 20.6 & 20.3 & 20.0 & 19.9 & 19.2 & 19.2 & 19.2 \\
\hline Lumen Depreciation & $22 \%$ & $23 \%$ & $25 \%$ & $25 \%$ & $26 \%$ & $27 \%$ & $28 \%$ & $29 \%$ & $31 \%$ & $31 \%$ & $30 \%$ & $31 \%$ & $32 \%$ & $32 \%$ & $35 \%$ & $35 \%$ & $35 \%$ \\
\hline
\end{tabular}

\section{Lumen Depreciation}

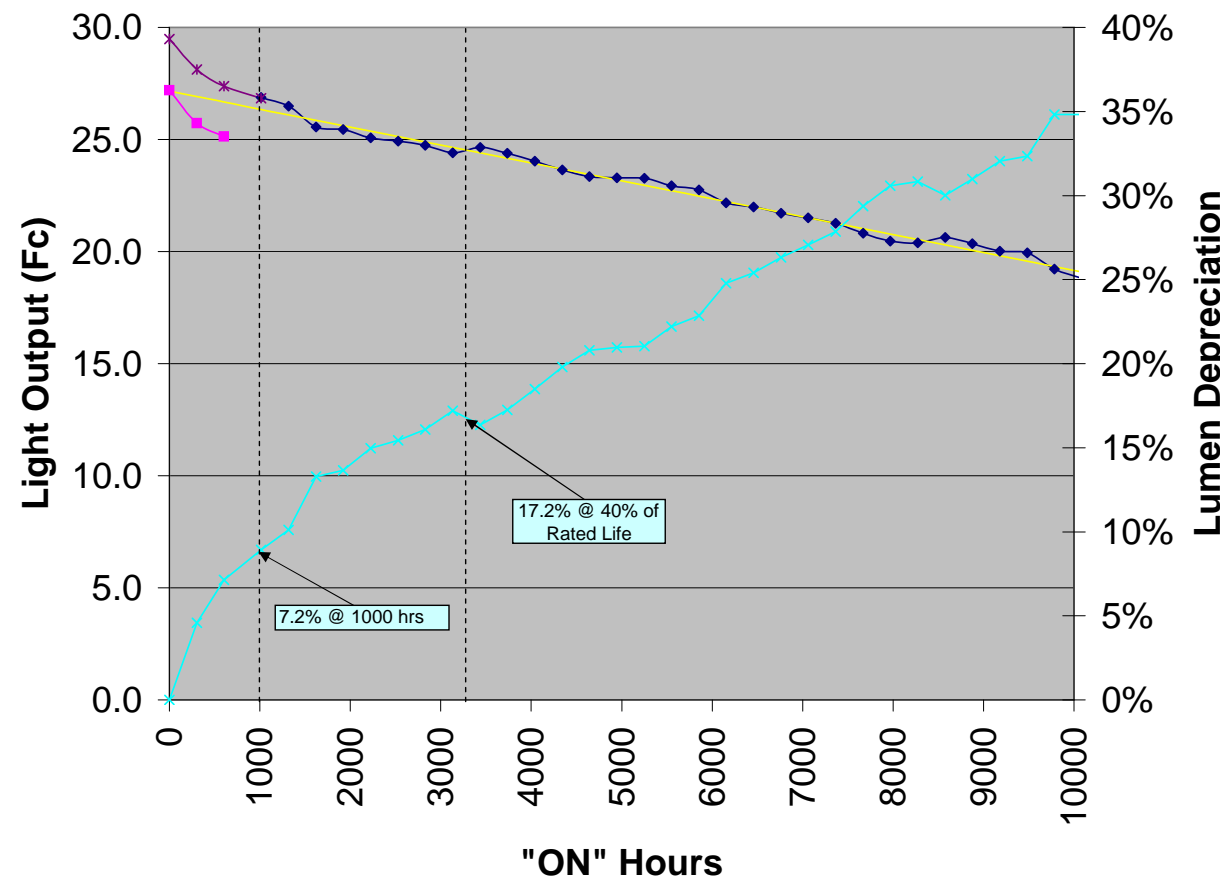

$\rightarrow-$ Initial Test (avg.)

- Supplemental Test (avg.)

* Supplemental+Curve-fit Linear-fit to Initial Test

- Lumen Depreciation 


\section{$\underset{\text { Pacific Northwed by Batelele for the U.S. Department of Energy }}{\text { Opatory }}$}

\section{SE= \\ ELECtrLC}

Manufacturer: Feit

Lamp Model: $\quad$ ESL18R40H 18W (ESL18PAR38H 18W)

Test Facility: Luminaire Testing Laboratory, Allentown, PA

Date Provided: $\quad 6 / 5 / 2008$

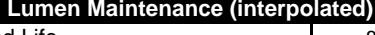

Rated Life

$1000 \mathrm{hr}$

$40 \%$ of Rated Life \begin{tabular}{l|l|}
3200 & $78.47 \%$ \\
\hline
\end{tabular}

\section{Life and Lumen Maintenance Report}

\begin{tabular}{|c|c|c|c|c|c|c|c|c|c|c|c|c|c|c|c|c|c|c|c|}
\hline & & & & & & & & SWIEN & VTENA & alues & fc) & & & & & & & & \\
\hline Date & $6 / 15 / 06$ & $6 / 21 / 06$ & $6 / 28 / 06$ & $7 / 5 / 06$ & $7 / 12 / 06$ & $7 / 19 / 06$ & $7 / 26 / 06$ & $8 / 2 / 06$ & $8 / 16 / 06$ & $8 / 30 / 06$ & $9 / 13 / 06$ & $9 / 27 / 06$ & $10 / 11 / 06$ & $10 / 25 / 06$ & $11 / 8 / 06$ & $11 / 22 / 06$ & $12 / 6 / 06$ & $12 / 20 / 06$ & $1 / 3 / 07$ \\
\hline "ON" hrs. & 0.0 & 129.6 & 280.8 & 432.0 & 583.2 & 734.4 & 885.6 & 1036.8 & 1339.2 & 1641.6 & 1944.0 & 2246.4 & 2548.8 & 2851.2 & 3153.6 & 3456.0 & 3758.4 & 4060.8 & 4363.2 \\
\hline \multicolumn{20}{|l|}{ Lamp Cell } \\
\hline B1 & 33.72 & 34.00 & 33.25 & 33.16 & 30.96 & 30.55 & 30.52 & 29.28 & 28.58 & 27.23 & 27.78 & 27.30 & 27.54 & 27.45 & 25.24 & 26.01 & 26.25 & 26.11 & 25.07 \\
\hline D6 & 36.62 & 35.90 & 34.43 & 34.14 & 33.41 & 33.04 & 32.53 & 31.90 & 31.24 & 31.09 & 31.28 & 30.88 & 30.65 & 30.88 & 30.40 & 30.41 & 30.31 & 30.59 & 29.98 \\
\hline D5 & 36.61 & 35.54 & 35.11 & 34.70 & 33.89 & 33.58 & 33.62 & 32.40 & 31.83 & 32.10 & 31.40 & 31.30 & 31.61 & 31.33 & 30.95 & 30.38 & 30.39 & 30.71 & 29.93 \\
\hline E6 & 35.41 & 34.18 & 34.31 & 34.39 & 33.70 & 33.60 & 33.18 & 32.47 & 31.27 & 30.91 & 30.05 & 29.62 & 28.61 & 28.47 & 27.70 & 27.46 & 28.51 & 28.53 & 28.22 \\
\hline E5 & 36.23 & 35.26 & 32.10 & 32.70 & 31.32 & 31.30 & 31.60 & 30.20 & 30.42 & 28.49 & 28.98 & 28.80 & 28.75 & 29.00 & 27.96 & 27.66 & 27.83 & 27.87 & 26.69 \\
\hline C1 & 35.51 & 34.23 & 32.94 & 32.01 & 31.69 & 31.12 & 29.58 & 30.54 & 30.18 & 30.05 & 29.41 & 28.61 & 28.96 & 28.92 & 28.26 & 28.02 & 27.96 & 28.12 & 27.67 \\
\hline E4 & 37.48 & 36.47 & 35.15 & 34.57 & 34.19 & 33.69 & 33.55 & 33.06 & 32.43 & 32.17 & 30.28 & 31.20 & 31.32 & 31.41 & 30.75 & 30.28 & 30.50 & 30.37 & 30.28 \\
\hline D4 & 38.90 & 35.85 & 35.13 & 34.12 & 33.16 & 32.94 & 32.78 & 31.35 & 30.63 & 30.47 & 29.96 & 29.30 & 29.16 & 28.05 & 27.35 & 26.67 & 26.82 & 26.81 & 26.20 \\
\hline D1 & 33.37 & 32.70 & 31.53 & 31.16 & 30.56 & 29.86 & 29.64 & 28.38 & 28.44 & 28.08 & 27.03 & 25.95 & 26.24 & 26.49 & 26.09 & 25.46 & 25.33 & 25.82 & 25.46 \\
\hline E1 & 34.78 & 33.21 & 33.12 & 31.75 & 30.64 & 31.89 & 31.58 & 30.59 & 29.66 & 29.19 & 28.63 & 28.21 & 28.19 & 27.63 & 27.11 & 26.99 & 27.52 & 27.00 & 27.03 \\
\hline
\end{tabular}

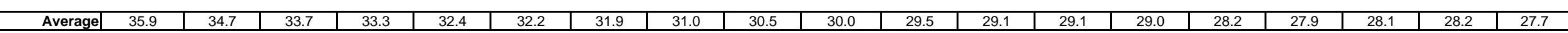

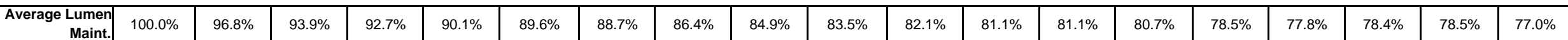

\begin{tabular}{|c|c|c|c|c|c|c|c|c|c|c|c|c|c|c|c|c|c|c|c|}
\hline \multicolumn{20}{|c|}{$\mathrm{N} /$} \\
\hline Date & $1 / 17 / 07$ & $1 / 31 / 07$ & $2 / 14 / 07$ & $2 / 28 / 07$ & $3 / 14 / 07$ & $3 / 28 / 07$ & $4 / 11 / 07$ & $4 / 25 / 07$ & $5 / 9 / 07$ & $5 / 23 / 07$ & $6 / 6 / 07$ & $6 / 20 / 07$ & $7 / 4 / 07$ & $7 / 18 / 07$ & $8 / 1 / 07$ & $8 / 15 / 07$ & $8 / 29 / 07$ & $9 / 12 / 07$ & $9 / 26 / 07$ \\
\hline "ON" hrs. & 4665.6 & 4968.0 & 5270.4 & 5572.8 & 5875.2 & 6177.6 & 6480.0 & 6782.4 & 7084.8 & 7387.2 & 7689.6 & 7992.0 & 8294.4 & 8596.8 & 8899.2 & 9201.6 & 9504.0 & 9806.4 & 10108.8 \\
\hline \multicolumn{20}{|l|}{ Lamp Cell } \\
\hline B1 & 26.65 & 26.87 & 26.41 & 27.38 & 25.78 & 25.52 & 26.57 & 25.25 & 25.99 & 25.70 & 25.20 & 25.19 & 25.21 & & & & & & \\
\hline D6 & 30.84 & 29.94 & 29.75 & 30.06 & 29.21 & 29.01 & 28.91 & 29.16 & 28.94 & 28.54 & 28.21 & 28.34 & 28.06 & & & & & & \\
\hline D5 & 30.55 & 30.30 & 30.56 & 29.58 & 29.47 & 28.95 & 28.45 & 29.34 & 28.58 & 27.98 & 27.62 & 27.11 & 27.04 & & & & & & \\
\hline E6 & 28.18 & 28.43 & 27.66 & 27.55 & 26.60 & 26.22 & 25.20 & 24.98 & 23.84 & & & & & & & & & & \\
\hline E5 & 27.66 & 27.01 & 26.98 & 26.71 & 25.80 & 25.87 & 25.07 & 25.81 & 25.51 & 25.09 & 24.83 & 24.87 & 24.65 & & \multirow{2}{*}{\multicolumn{3}{|c|}{ Completed 8000 hours }} & & \\
\hline $\mathrm{C} 1$ & 27.98 & 28.02 & 28.03 & 28.34 & 27.37 & 27.38 & 26.67 & 27.11 & 27.06 & 26.61 & 26.36 & 26.31 & 26.28 & & corm & & & & \\
\hline E4 & 30.40 & 30.11 & 29.61 & 29.88 & 29.27 & 28.91 & 28.45 & 29.03 & 28.41 & 28.32 & 28.31 & 28.24 & 28.18 & & & & & & \\
\hline D4 & 26.50 & 25.74 & 25.97 & 26.70 & 25.85 & 25.82 & 25.78 & 25.93 & 24.92 & 24.43 & 23.78 & 23.62 & 23.14 & & & & & & \\
\hline D1 & 26.44 & 26.48 & 26.09 & 26.28 & 25.73 & 25.37 & 25.51 & 25.20 & 24.71 & 24.16 & 24.01 & 23.97 & 23.18 & & & & & & \\
\hline E1 & 27.66 & 27.39 & 27.06 & 26.82 & 26.21 & 26.79 & 27.12 & 27.45 & 25.72 & 26.65 & 26.41 & 26.14 & 26.10 & & & & & & \\
\hline Average & 28.3 & 28.0 & 27.8 & 27.9 & 27.1 & 27.0 & 26.8 & 26.9 & 26.4 & 26.4 & 26.1 & 26.0 & 25.8 & & & & & & \\
\hline & & & & & & & & & & & & & & & & & & & \\
\hline $\begin{array}{r}\text { Average Lumen } \\
\text { Maint. }\end{array}$ & $78.8 \%$ & $78.1 \%$ & $77.5 \%$ & $77.8 \%$ & $75.6 \%$ & $75.2 \%$ & $74.6 \%$ & $75.0 \%$ & $73.4 \%$ & $73.5 \%$ & $72.6 \%$ & $72.4 \%$ & $71.8 \%$ & & & & & & \\
\hline
\end{tabular}

Comments: 


\section{Pacific Northwest National Laboratory \\ Operated by Battelle for the U.S. Department of Energy}

\section{OF}

Lamp Model: $\quad$ ESL18R40H 18W (ESL18PAR38H 18W)

Test Facility: Luminaire Testing Laboratory, Allentown, PA

Luminaire

Lumed Life

$1000 \mathrm{hr}$.

$40 \%$ of Rated Life

3200

Individual Lamp Illuminance and Life

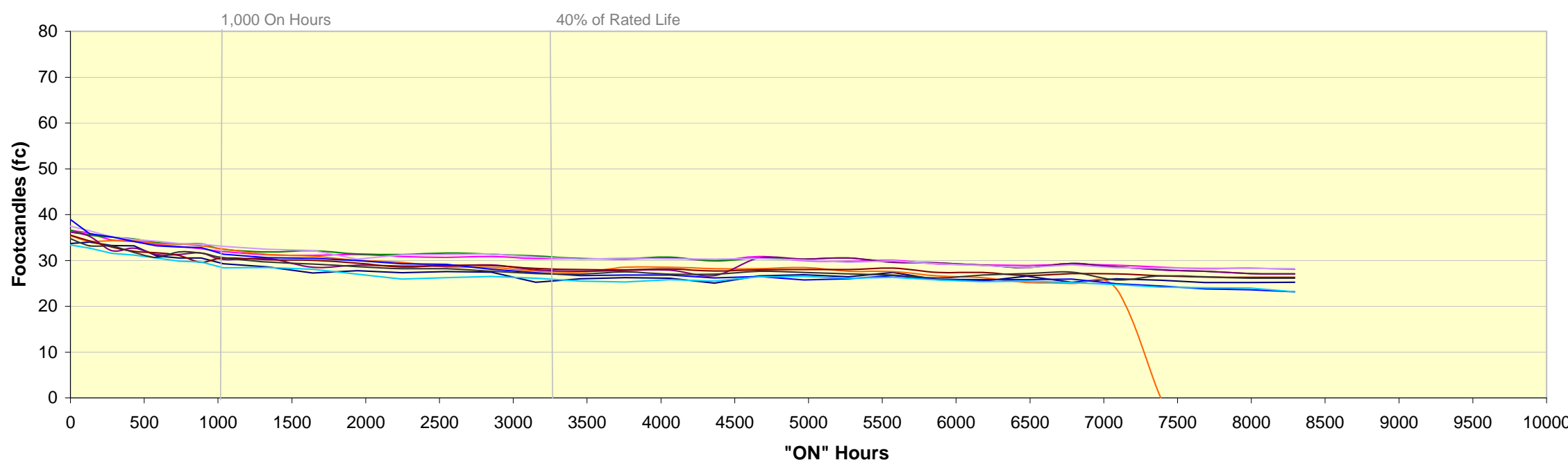

Average Lumen Maintenance

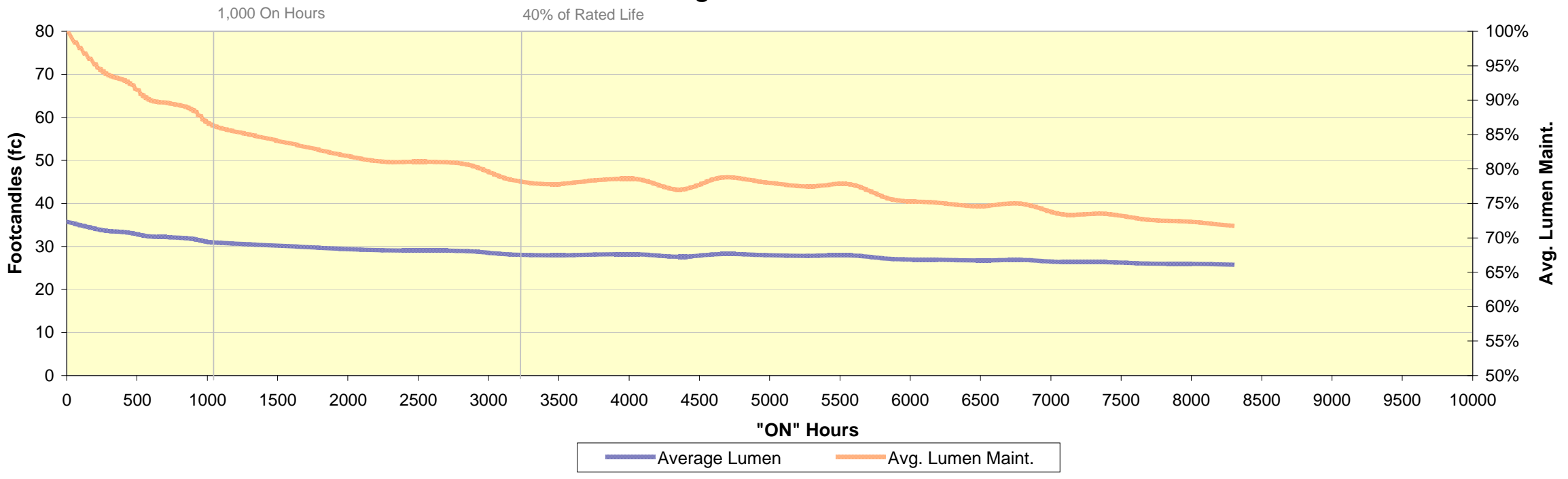




\section{$\underset{\text { Pacific Northwed by Batelele for the U.S. Department of Energy }}{\text { Opatory }}$}

\section{(2)}

Lamp Model: BPCE23R40/3 23W (BPCE23PAR38/3 23W)

Test Facility: Luminaire Testing Laboratory, Allentown, PA

Date Provided: 6/5/2008

Test Number: 09659

\section{Life and Lumen Maintenance Report}

\begin{tabular}{|c|c|c|c|c|c|c|c|c|c|c|c|c|c|c|c|c|c|c|c|}
\hline \multicolumn{20}{|c|}{ AINTEN } \\
\hline Date & $6 / 15 / 06$ & $6 / 21 / 06$ & $6 / 28 / 06$ & $715 / 06$ & $7 / 12 / 06$ & $7 / 19 / 06$ & $7 / 26 / 06$ & $8 / 2 / 06$ & $8 / 16 / 06$ & $8 / 30 / 06$ & $9 / 13 / 06$ & $9 / 27 / 06$ & $10 / 11 / 06$ & $10 / 25 / 06$ & $11 / 8 / 06$ & $11 / 22 / 06$ & $12 / 6 / 06$ & $12 / 20 / 06$ & $1 / 3 / 07$ \\
\hline "ON" hrs. & 0.0 & 129.6 & 280.8 & 432.0 & 583.2 & 734.4 & 885.6 & 1036.8 & 1339.2 & 1641.6 & 1944.0 & 2246.4 & 2548.8 & 2851.2 & 3153.6 & 3456.0 & 3758.4 & 4060.8 & 4363.2 \\
\hline \multicolumn{20}{|l|}{ Lamp Cell } \\
\hline A1 & 57.66 & 56.56 & 54.13 & 55.03 & 52.86 & 52.52 & 52.49 & 51.11 & 51.03 & 50.35 & 49.49 & 48.30 & 47.96 & 48.36 & 47.50 & 46.55 & 46.75 & 47.04 & 45.89 \\
\hline A3 & 61.36 & 58.59 & 54.97 & 54.76 & 55.02 & 52.35 & 53.01 & 51.38 & 50.45 & 51.03 & 48.18 & 48.12 & 49.81 & 47.58 & 47.28 & 45.73 & 46.85 & 46.39 & 45.43 \\
\hline B2 & 65.50 & 65.42 & 61.19 & 62.58 & 60.72 & 61.14 & 61.22 & 60.16 & 57.67 & 55.91 & 55.21 & 53.79 & 54.21 & 52.82 & 51.23 & 50.82 & 51.94 & 52.01 & 50.37 \\
\hline A5 & 59.45 & 58.59 & 54.90 & 53.23 & 53.50 & 52.51 & 52.39 & 51.44 & 50.03 & 49.44 & 48.45 & 48.79 & 49.50 & 48.67 & 48.89 & 47.92 & 47.44 & 46.81 & 45.66 \\
\hline A4 & 69.46 & 66.75 & 62.89 & 60.08 & 59.23 & 57.87 & 58.15 & 56.33 & 54.47 & 53.21 & 50.84 & 49.73 & 50.79 & 49.82 & 48.90 & 47.90 & 47.53 & 46.98 & 45.94 \\
\hline $\mathrm{C} 2$ & 59.49 & 58.69 & 58.05 & 54.00 & 52.98 & 51.26 & 51.25 & 50.93 & 50.73 & 49.56 & 49.88 & 47.94 & 49.55 & 47.16 & 47.59 & 46.10 & 45.88 & 45.84 & 46.48 \\
\hline F10 & 60.91 & 59.78 & 57.69 & 54.70 & 53.80 & 52.73 & 51.49 & 51.64 & 50.70 & 50.20 & 47.80 & 48.30 & 47.14 & 46.92 & 47.34 & 49.20 & 49.45 & 47.60 & 45.97 \\
\hline D2 & 65.78 & 65.66 & 63.24 & 64.10 & 63.08 & 62.08 & 62.12 & 61.44 & 60.84 & 58.89 & 56.98 & 56.55 & 55.81 & 53.80 & 52.99 & 52.40 & 52.06 & 54.03 & 52.73 \\
\hline E2 & 61.88 & 61.30 & 59.11 & 56.15 & 57.12 & 54.50 & 55.20 & 55.69 & 54.54 & 53.93 & 51.92 & 50.76 & 52.01 & 51.45 & 50.77 & 48.90 & 47.84 & 49.01 & 47.18 \\
\hline A2 & 50.27 & 42.18 & 43.73 & 46.05 & 44.92 & 45.17 & 46.05 & 44.95 & 44.56 & 43.64 & 43.97 & 43.61 & 43.29 & 42.37 & 41.55 & 41.37 & 38.42 & 41.05 & 39.28 \\
\hline
\end{tabular}

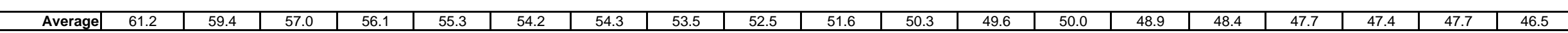

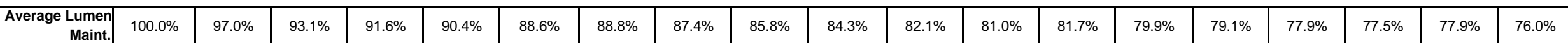

\begin{tabular}{|c|c|c|c|c|c|c|c|c|c|c|c|c|c|c|c|c|c|c|c|}
\hline \multirow{2}{*}{\multicolumn{20}{|c|}{$2 / 14 / 07$}} \\
\hline & $1 / 17 / 07$ & $1 / 31 / 07$ & 2/14/07 & 2/28/07 & $3 / 14 / 07$ & $3 / 28 / 07$ & 4/11/07 & $4 / 25 / 07$ & $5 / 9 / 07$ & $5 / 23 / 07$ & $6 / 6 / 07$ & $6 / 20 / 07$ & $7 / 4 / 07$ & $7 / 18 / 07$ & $8 / 1 / 07$ & $8 / 15 / 07$ & $8 / 29 / 07$ & $9 / 12 / 07$ & $9 / 26 / 07$ \\
\hline "ON" hrs. & 4665.6 & 4968.0 & 5270.4 & 5572.8 & 5875.2 & 6177.6 & 6480.0 & 6782.4 & 7084.8 & 7387.2 & 7689.6 & 7992.0 & 8294.4 & 8596.8 & 8899.2 & 9201.6 & 9504.0 & 9806.4 & 10108.8 \\
\hline \multicolumn{20}{|l|}{ Lamp Cell } \\
\hline A1 & 45.89 & 45.84 & 45.01 & 45.35 & 43.34 & 42.35 & 42.56 & 43.58 & 43.03 & 42.52 & 41.26 & 41.19 & 41.12 & & & & & & \\
\hline A3 & 47.24 & 44.52 & 43.84 & 46.22 & 43.09 & 42.37 & 44.38 & 43.98 & 44.16 & 41.72 & 41.80 & 41.87 & 41.96 & & & & & & \\
\hline B2 & 50.00 & 51.37 & 49.33 & 49.32 & 49.25 & 47.88 & 50.03 & 48.84 & & & & & & & & & & & \\
\hline A5 & 46.49 & 45.65 & 45.20 & 45.25 & 43.55 & 42.37 & 42.15 & & & & & & & & & & & & \\
\hline A4 & 47.91 & 45.97 & 46.33 & 46.37 & 45.00 & 45.30 & 43.72 & & & & & & & & \multirow{2}{*}{\multicolumn{4}{|c|}{ Completed 8000 hours }} & \\
\hline $\mathrm{C2}$ & 46.82 & 46.43 & 46.04 & 44.65 & 43.70 & 43.61 & 44.07 & 45.14 & 43.19 & 42.34 & 40.49 & 42.14 & 43.71 & & & & & & \\
\hline F10 & 46.37 & 46.16 & 47.68 & 47.49 & 44.37 & 45.82 & 46.03 & 45.88 & 44.53 & 40.79 & 44.01 & 43.86 & 43.18 & & & & & & \\
\hline D2 & 52.44 & 51.48 & 52.56 & 53.56 & 50.91 & 50.55 & 50.70 & 50.32 & 50.57 & 49.88 & 49.37 & 48.65 & 48.00 & & & & & & \\
\hline E2 & 47.40 & 46.98 & 46.62 & 48.37 & 45.50 & 44.56 & 44.77 & 44.69 & 43.90 & 43.01 & 42.23 & 42.14 & 42.01 & & & & & & \\
\hline A2 & 41.14 & 41.01 & 40.63 & 40.50 & 39.61 & 39.39 & & & & & & & & & & & & & \\
\hline Average & 47.2 & 46.5 & 46.3 & 46.7 & 44.8 & 44.4 & 45.4 & 46.1 & 44.9 & 43.4 & 43.2 & 43.3 & 43.3 & & & & & & \\
\hline $\begin{array}{r}\text { Average Lumen } \\
\text { Maint. }\end{array}$ & $77.1 \%$ & $76.0 \%$ & $75.7 \%$ & $76.3 \%$ & $73.3 \%$ & $72.6 \%$ & $74.1 \%$ & $75.3 \%$ & $73.4 \%$ & $70.9 \%$ & $70.6 \%$ & $70.8 \%$ & $70.8 \%$ & & & & & & \\
\hline
\end{tabular}

Comments:

Lamp A2 failed on 4/9/07 at $6418.8 \mathrm{hrs}$ Lamp A5 failed on 4/14/07 at $6525.9 \mathrm{hrs}$ Lamp B2 failed on 5/5/07 at $6842.0 \mathrm{hrs}$ 


\section{$\underset{\text { Pacific Northed by Batelele for the U.S. Department of Energy }}{\text { Patory }}$}

\section{OF=}

Manufacturer: $\quad$ Feit

Test Facility: Luminaire Testing Laboratory, Allentown, PA 6/5/2008

Lumed Life

$1000 \mathrm{hr}$.

$40 \%$ of Rated Life 3200 $78.94 \%$

\section{Individual Lamp Illuminance and Life}

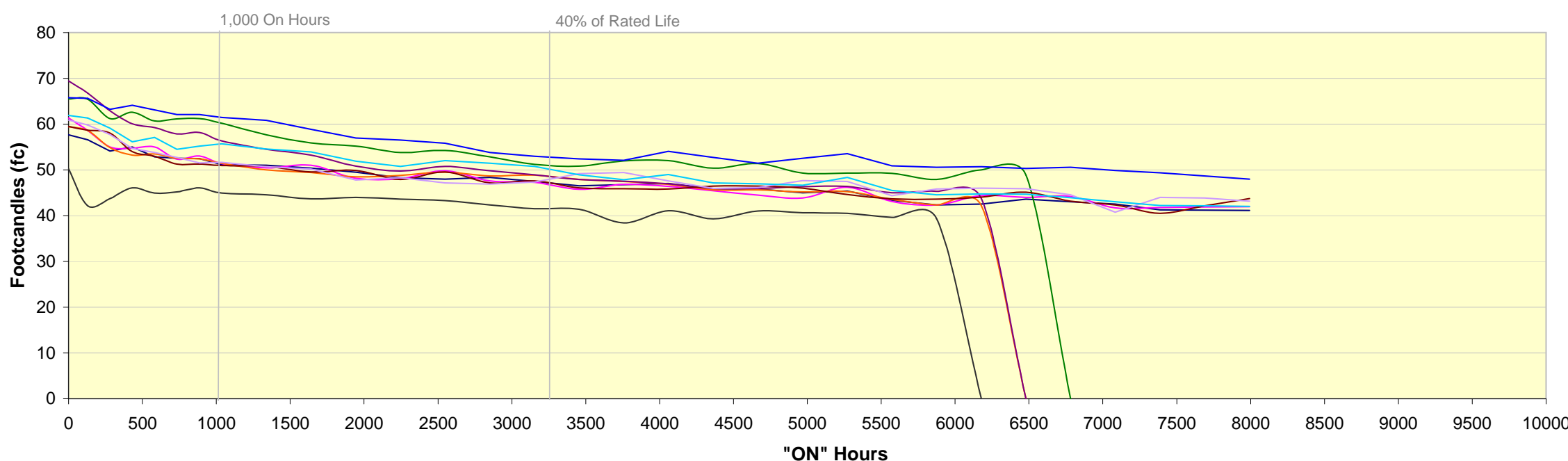

Average Lumen Maintenance

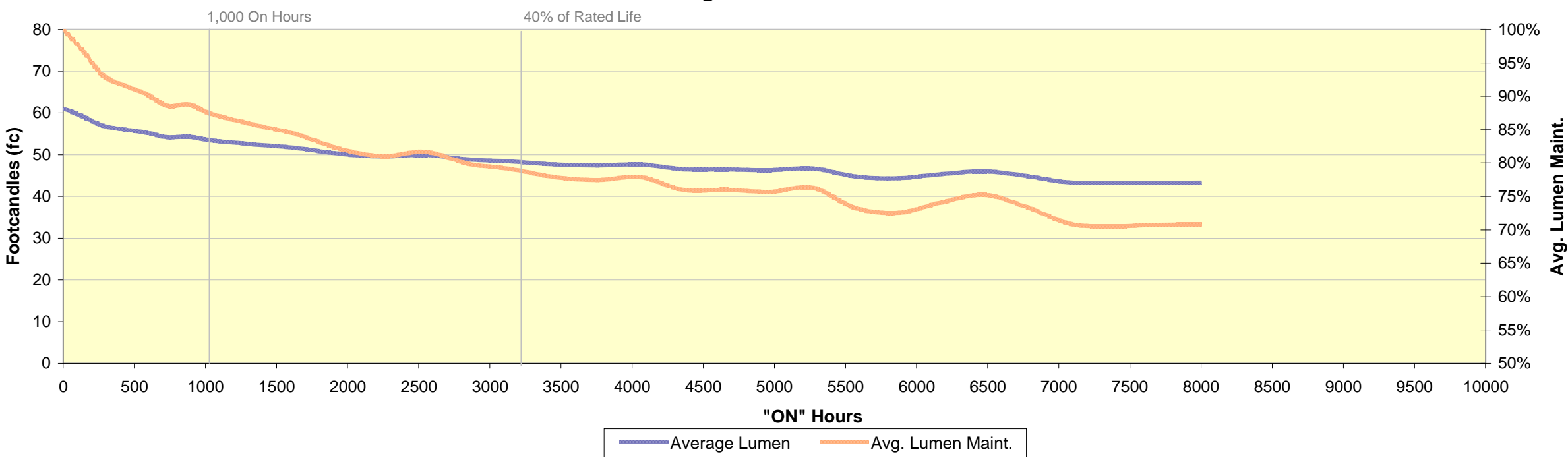




\section{Pacific Northwest National Laboratory}

Manufacturer: $\quad G E$

Lamp Model: $\quad$ FLE15/2/DV/R30

Test Facility: $\quad$ Luminaire Testing Laboratory, Allentown, PA

Date Provided: 6/5/2008

Test Number: 09260

\section{Life and Lumen Maintenance Report}

\begin{tabular}{|c|c|c|c|c|c|c|c|c|c|c|c|c|c|c|c|c|c|c|c|}
\hline \multirow{2}{*}{\multicolumn{20}{|c|}{\begin{tabular}{l|c|c|c|c|} 
& \multicolumn{1}{c}{ LUMEN MAINTENANCE (values in fc) } \\
$2 / 15 / 06$ & $3 / 1 / 06$ & $3 / 15 / 06$ & $3 / 29 / 06$ & $4 / 12 / 06$
\end{tabular}}} \\
\hline & $1 / 4 / 06$ & $1 / 11 / 06$ & $1 / 18 / 06$ & $1 / 25 / 06$ & $2 / 1 / 06$ & $2 / 8 / 06$ & $2 / 15 / 06$ & $3 / 1 / 06$ & $3 / 15 / 06$ & $3 / 29 / 06$ & $4 / 12 / 06$ & $4 / 26 / 06$ & $5 / 10 / 06$ & $5 / 24 / 06$ & $6 / 7 / 06$ & $6 / 21 / 06$ & $7 / 5 / 06$ & $7 / 19 / 06$ & \\
\hline "ON" hrs. & 0.0 & 151.2 & 302.4 & 453.6 & $\begin{array}{l}604.8 \\
\end{array}$ & 756.0 & 907.2 & 1209.6 & 1512.0 & \begin{tabular}{|l|l|}
1814.4 \\
\end{tabular} & $\begin{array}{l}2116.8 \\
\end{array}$ & 2419.2 & 2721.6 & 3024.0 & 3326.4 & 3628.8 & 3931.2 & 4233.6 & 4536.0 \\
\hline \multicolumn{20}{|l|}{ Lamp Cell } \\
\hline C6 & 28.06 & 26.27 & 25.76 & 25.67 & 25.26 & 25.11 & 24.68 & 24.64 & 24.51 & 23.38 & 23.16 & 22.95 & 23.03 & 22.74 & 22.91 & 22.65 & 22.36 & 21.84 & 21.5 \\
\hline $\mathrm{C} 5$ & 28.89 & 26.93 & 26.01 & 25.57 & 24.98 & 24.63 & 24.05 & 23.71 & 24.57 & 22.45 & 22.20 & 21.98 & 22.15 & 22.13 & 21.35 & 20.97 & 20.85 & 20.6 & 20.56 \\
\hline $\mathrm{C} 4$ & 27.10 & 25.36 & 25.00 & 24.75 & 24.49 & 24.16 & 24.02 & 24.22 & 24.02 & 23.22 & 23.18 & 22.97 & 22.78 & 22.54 & 22.72 & 22.57 & 22.45 & 22.25 & 22.2 \\
\hline D4 & 28.07 & 25.70 & 25.48 & 25.33 & 25.08 & 24.96 & 24.65 & 24.63 & 24.26 & 23.44 & 23.29 & 23.13 & 22.67 & 22.42 & 22.30 & 22.18 & 22.06 & 21.94 & 21.84 \\
\hline E4 & 29.03 & 26.90 & 26.55 & 26.24 & 25.90 & 25.77 & 25.27 & 25.39 & 24.97 & 24.09 & 23.96 & 23.80 & 23.56 & 23.13 & 23.46 & 23.10 & 22.99 & 22.65 & 22.64 \\
\hline F4 & 25.57 & 23.90 & 23.26 & 23.03 & 22.27 & 21.76 & 21.02 & 20.96 & 20.56 & 19.00 & 19.02 & & & & & & & & \\
\hline $\mathrm{G} 4$ & 25.36 & 23.95 & 23.77 & 23.74 & 23.14 & 22.91 & 22.50 & 22.60 & 22.30 & 21.10 & 20.96 & 20.80 & 20.43 & 20.08 & 20.05 & 19.94 & 19.70 & 19.39 & 19.44 \\
\hline $\mathrm{H} 4$ & 28.02 & 27.16 & 27.05 & 26.98 & 26.48 & 26.32 & 25.92 & 25.90 & 25.91 & 24.92 & 24.89 & 24.72 & 24.49 & 24.29 & 24.36 & 24.18 & 24.00 & 23.75 & 23.71 \\
\hline $\mathrm{C} 7$ & 26.18 & 24.38 & 23.81 & 23.62 & 23.14 & 23.02 & 22.70 & 22.68 & 22.54 & 22.05 & 22.02 & 21.82 & 21.58 & 21.44 & 21.42 & 21.25 & 21.09 & 20.88 & 20.70 \\
\hline D7 & 27.05 & 25.78 & 25.19 & 24.87 & 24.53 & 24.34 & 23.91 & 23.87 & 23.76 & 22.92 & 22.79 & 22.72 & 22.47 & 22.37 & 22.30 & 22.24 & 22.05 & 21.62 & 21.45 \\
\hline
\end{tabular}

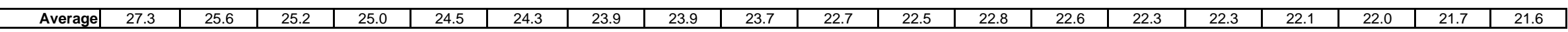

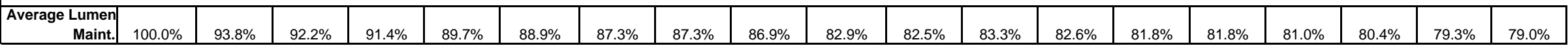

\begin{tabular}{|c|c|c|c|c|c|c|c|c|c|c|c|c|c|c|c|c|c|c|c|}
\hline \multicolumn{20}{|c|}{ LUMEN MAINTENANCE (values in fc) continued } \\
\hline Date & $8 / 16 / 06$ & $8 / 30 / 06$ & 9/13/06 & 9/27/06 & $10 / 11 / 06$ & $10 / 25 / 06$ & $11 / 8 / 06$ & $11 / 22 / 06$ & $12 / 6 / 06$ & $12 / 20 / 06$ & $1 / 3 / 07$ & $1 / 17 / 07$ & $1 / 31 / 07$ & $2 / 14 / 07$ & $2 / 28 / 07$ & $3 / 14 / 07$ & $3 / 28 / 07$ & $4 / 11 / 07$ & $4 / 25 / 07$ \\
\hline "ON" hrs. & 4838.4 & 5140.8 & 5443.2 & 5745.6 & 6048.0 & 6350.4 & 6652.8 & 6955.2 & 7257.6 & 7560.0 & 7862.4 & 8164.8 & 8467.2 & 8769.6 & 9072.0 & 9374.4 & $\begin{array}{l}9676.8 \\
\end{array}$ & 9979.2 & 10281.6 \\
\hline \multicolumn{20}{|l|}{ Lamp Cell } \\
\hline $\mathrm{C} 6$ & 21.87 & 22.02 & 21.80 & 21.72 & 21.87 & & & & & & & & & & & & & & \\
\hline $\mathrm{C5}$ & 20.39 & 20.23 & 20.11 & 19.94 & 20.15 & & & & & & & & & & & & & & \\
\hline $\mathrm{C} 4$ & 21.95 & 21.88 & 21.77 & 21.76 & 22.08 & & & & & & & & & & & & & & \\
\hline D4 & 21.55 & 21.33 & 21.13 & 21.00 & 21.11 & & & & & & & & & & & & & & \\
\hline E4 & 22.23 & 22.13 & 21.84 & 21.80 & 21.87 & & \multirow{2}{*}{\multicolumn{3}{|c|}{ Completed 6000 hours }} & & & & & & & & & & \\
\hline F4 & & & & & & & & & & & & & & & & & & & \\
\hline G4 & 19.12 & 18.80 & 18.76 & 18.68 & 18.70 & & & & & & & & & & & & & & \\
\hline $\mathrm{H} 4$ & 23.49 & 23.37 & 23.24 & 23.11 & 23.13 & & & & & & & & & & & & & & \\
\hline $\mathrm{C} 7$ & 20.62 & 20.71 & 20.59 & 20.47 & 20.69 & & & & & & & & & & & & & & \\
\hline D7 & 21.19 & 21.25 & 21.08 & 21.10 & 21.24 & & & & & & & & & & & & & & \\
\hline
\end{tabular}

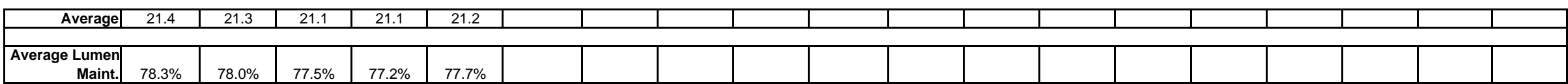

Comments: 


\section{Pacific Northwest National Laboratory}

\section{Individual Lamp Illuminance and Life}

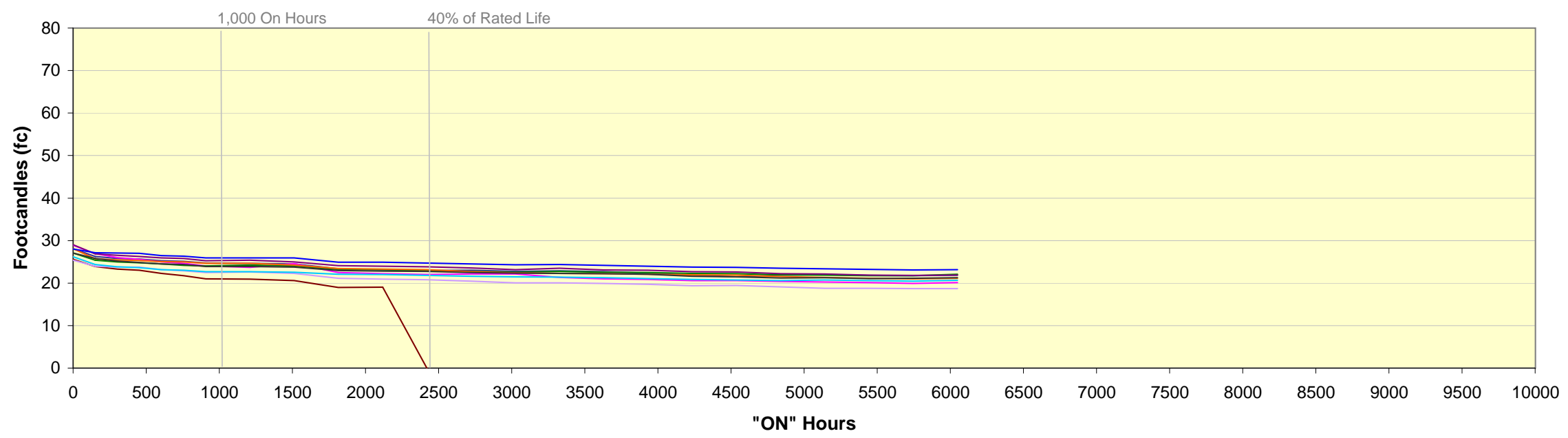

Average Lumen Maintenance

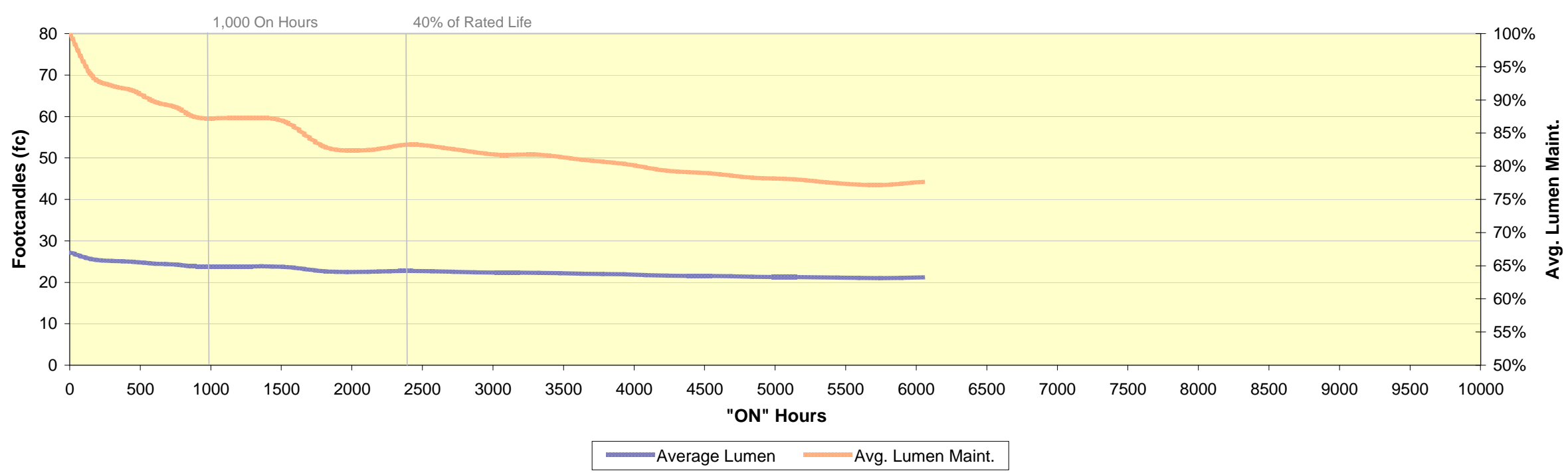




\section{$\underset{\text { Pacerated by Batelle for the U.S. Department of Energy }}{\text { Patific North }}$}

Manufacturer: $\mathrm{GE}$

Lamp Model: $\quad$ FLE15/2/R30XL

Test Facility: $\quad$ Luminaire Testing Laboratory, Allentown, PA

Date Provided: $\quad 6 / 5 / 2008$

Test Number: $\quad 09259$

\section{Life and Lumen Maintenance Report}

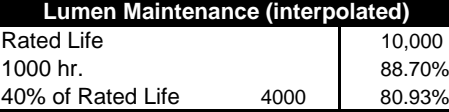

\begin{tabular}{|c|c|c|c|c|c|c|c|c|c|c|c|c|c|c|c|c|c|c|c|}
\hline \multicolumn{20}{|c|}{ LUMEN MAINTENANCE (values in fc) } \\
\hline Date & $1 / 4 / 06$ & $1 / 11 / 06$ & $1 / 18 / 06$ & $1 / 25 / 06$ & $2 / 1 / 06$ & $2 / 8 / 06$ & $2 / 15 / 06$ & $3 / 1 / 06$ & $3 / 15 / 06$ & $3 / 29 / 06$ & $4 / 12 / 06$ & $4 / 26 / 06$ & $5 / 10 / 06$ & $5 / 24 / 06$ & $6 / 7 / 06$ & $6 / 21 / 06$ & $7 / 5 / 06$ & $7 / 19 / 06$ & $8 / 2 / 06$ \\
\hline "ON" hrs. & 0.0 & 151.2 & 302.4 & 453.6 & 604.8 & 756.0 & 907.2 & 1209.6 & 1512.0 & 1814.4 & 2116.8 & 2419.2 & 2721.6 & 3024.0 & 3326.4 & 3628.8 & 3931.2 & $\begin{array}{ll}4233.6 \\
\end{array}$ & 4536.0 \\
\hline \multicolumn{20}{|l|}{ Lamp Cell } \\
\hline C6 & 27.29 & 25.99 & 25.21 & 24.99 & 24.50 & 24.22 & 24.01 & 23.48 & 23.27 & 22.84 & 22.34 & 22.33 & 21.93 & 21.97 & 21.75 & 21.93 & 21.73 & 21.57 & 21.27 \\
\hline $\mathrm{C} 7$ & 25.85 & 24.38 & 23.15 & 23.18 & 22.78 & 22.49 & 22.33 & 21.87 & 21.41 & 21.00 & 20.98 & 20.93 & 20.58 & 20.46 & 20.48 & 20.31 & 20.13 & 20.03 & 18.97 \\
\hline $\mathrm{C} 8$ & 27.18 & 26.26 & 25.65 & 25.56 & 25.28 & 25.19 & 24.92 & 24.80 & 24.46 & 23.94 & 23.83 & 23.71 & 23.48 & 23.27 & 23.23 & 23.06 & 22.97 & 22.79 & 22.62 \\
\hline C9 & 28.27 & 27.09 & 26.71 & 26.37 & 25.98 & 25.65 & 25.48 & 25.01 & 24.76 & 24.31 & 24.10 & 23.92 & 23.75 & 23.68 & 23.57 & 23.45 & 23.46 & 23.21 & 23.00 \\
\hline D9 & 24.36 & 23.23 & 22.53 & 22.57 & 22.07 & 21.91 & 21.52 & 21.28 & 20.93 & 20.47 & 20.31 & 20.26 & 19.90 & 19.68 & 19.69 & 19.45 & 19.36 & 19.35 & 18.67 \\
\hline E9 & 27.49 & 25.99 & 25.17 & 24.82 & 24.43 & 24.19 & 23.78 & 23.35 & 22.93 & 22.22 & 21.94 & 21.88 & 21.76 & 20.65 & 21.68 & 21.22 & 21.18 & 20.98 & 20.94 \\
\hline F9 & 23.75 & 22.83 & 22.49 & 22.60 & 22.13 & 22.16 & 21.79 & 20.99 & 21.01 & 20.60 & 20.90 & 20.55 & 20.18 & 19.67 & 21.16 & 19.66 & 19.49 & 19.36 & 18.91 \\
\hline G9 & 26.41 & 25.52 & 24.98 & 24.70 & 24.29 & 24.43 & 24.30 & 23.20 & 23.61 & 23.09 & 22.95 & 23.03 & 22.50 & 22.45 & 22.61 & 22.12 & 22.00 & 21.47 & 21.54 \\
\hline $\mathrm{H} 9$ & 28.50 & 27.49 & 26.80 & 26.71 & 26.37 & 26.22 & 25.64 & 24.42 & 25.07 & 24.45 & 24.15 & 23.86 & 23.85 & 23.65 & 23.62 & 23.32 & 23.23 & 23.06 & 22.96 \\
\hline $\mathrm{H} 8$ & 27.29 & 26.13 & 25.50 & 25.27 & 24.90 & 24.75 & 24.50 & 23.44 & 23.90 & 23.46 & 23.30 & 23.22 & 23.01 & 22.84 & 22.87 & 22.52 & 22.46 & 22.39 & 21.92 \\
\hline
\end{tabular}

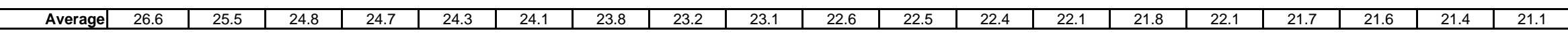

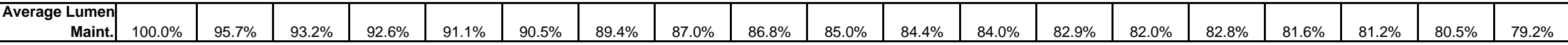

\begin{tabular}{|c|c|c|c|c|c|c|c|c|c|c|c|c|c|c|c|c|c|c|c|}
\hline Date & & & & & & & & & & & & & & & & & & & \\
\hline "ON" hrs. & 4838.4 & 5140.8 & 5443.2 & 57456 & 60480 & 63504 & 110100 & $11 / 2<106$ & $12 / 10 / 06$ & $12 \angle 20100$ & $1 / 3 / 01$ & $1 / 1 / 101$ & $1 / 31 / 07$ & $2 / 14 / 07$ & $2 / 28 / 07$ & $3 / 14 / 07$ & $3 / 28 / 07$ & 4/11/07 & $\begin{array}{r}4 / 25 / 07 \\
10281\end{array}$ \\
\hline \multicolumn{20}{|l|}{ Lamp Cell } \\
\hline $\mathrm{C} 6$ & 21.16 & 21.19 & 21.06 & 20.98 & 21.09 & 20.88 & 20.90 & 20.79 & 21.07 & 20.98 & 20.92 & 21.33 & 21.14 & 21.00 & 21.01 & 20.66 & 20.67 & 20.53 & 20.54 \\
\hline C7 & 19.41 & 19.49 & 19.27 & 19.05 & 19.32 & 18.76 & 18.89 & 18.80 & 19.13 & 19.00 & 18.80 & 19.14 & 18.80 & 18.63 & 18.67 & 18.23 & 18.18 & 18.33 & 18.23 \\
\hline $\mathrm{C} 8$ & 22.46 & 22.42 & 22.44 & 22.35 & 22.73 & 22.60 & 22.64 & 22.41 & 22.76 & 22.81 & 22.51 & 22.80 & 22.30 & 22.18 & 22.70 & 22.28 & 22.23 & 22.20 & 22.26 \\
\hline C9 & 23.07 & 23.10 & 22.96 & 22.77 & 23.05 & 22.97 & 22.83 & 22.78 & 23.06 & 22.93 & 22.84 & 23.41 & 23.24 & 22.90 & 23.24 & 22.60 & 22.60 & 22.52 & 22.53 \\
\hline D9 & 18.89 & 18.93 & 18.63 & 18.56 & 18.94 & 19.20 & 18.84 & 18.89 & 19.16 & 19.12 & 19.06 & 19.48 & 19.31 & 19.33 & 19.43 & 19.16 & 19.13 & 19.12 & 19.16 \\
\hline E9 & 21.00 & 20.82 & 20.72 & 20.50 & 20.65 & 20.60 & 20.43 & 20.35 & 20.42 & 20.25 & 20.10 & 20.60 & 20.07 & 20.05 & 20.08 & 19.84 & 19.65 & 19.61 & 19.70 \\
\hline F9 & 18.73 & 18.94 & 19.02 & 19.11 & 18.86 & 19.41 & 19.10 & 18.82 & 18.67 & 18.97 & 18.90 & 19.80 & 19.26 & 19.10 & 19.06 & 18.60 & 18.93 & 18.84 & 18.79 \\
\hline G9 & 21.35 & 21.38 & 21.17 & 21.08 & 20.94 & 20.96 & 20.80 & 20.64 & 20.76 & 20.56 & 20.66 & 21.12 & 20.49 & 20.50 & 20.40 & 20.09 & 20.04 & 20.24 & 20.30 \\
\hline $\mathrm{H} 9$ & 22.57 & 22.70 & 22.59 & 22.16 & 22.61 & 22.60 & 22.45 & 22.59 & 22.46 & 22.38 & 22.18 & 22.58 & 22.39 & 22.58 & 22.68 & 22.07 & 22.22 & 21.73 & 21.58 \\
\hline $\mathrm{H} 8$ & 21.85 & 21.83 & 21.58 & 21.53 & 22.00 & 21.90 & 21.75 & 21.65 & 21.87 & 21.99 & 21.65 & 22.00 & 21.81 & 21.70 & 21.44 & 21.26 & 21.32 & 21.24 & 21.45 \\
\hline Average & 21.0 & 21.1 & 20.9 & 20.8 & 21.0 & 21.0 & 20.9 & 20.8 & 20.9 & 20.9 & 20.8 & 21.2 & 20.9 & 20.8 & 20.9 & 20.5 & 20.5 & 20.4 & 20.5 \\
\hline \\
\hline Maint. & $79.1 \%$ & $79.2 \%$ & $78.7 \%$ & $78.2 \%$ & $79.0 \%$ & $78.9 \%$ & $78.4 \%$ & $78.1 \%$ & $78.7 \%$ & $78.6 \%$ & $78.1 \%$ & $79.8 \%$ & $78.5 \%$ & $78.2 \%$ & $78.5 \%$ & $77.0 \%$ & $77.1 \%$ & $76.8 \%$ & $76.9 \%$ \\
\hline
\end{tabular}

Comments:

Successfully completed 10,000 hours Elevated Temperature Life Testing 


\section{$\underset{\text { Pacerated by Battelle for the u.s. Department of Energy }}{\text { Patic Nory }}$}

Manufacturer: $\mathrm{GE}$

Lamp Model: $\quad$ FLE15/2/R30XL

Test Facility: Luminaire Testing Laboratory, Allentown, PA

\section{Individual Lamp Illuminance and Life}

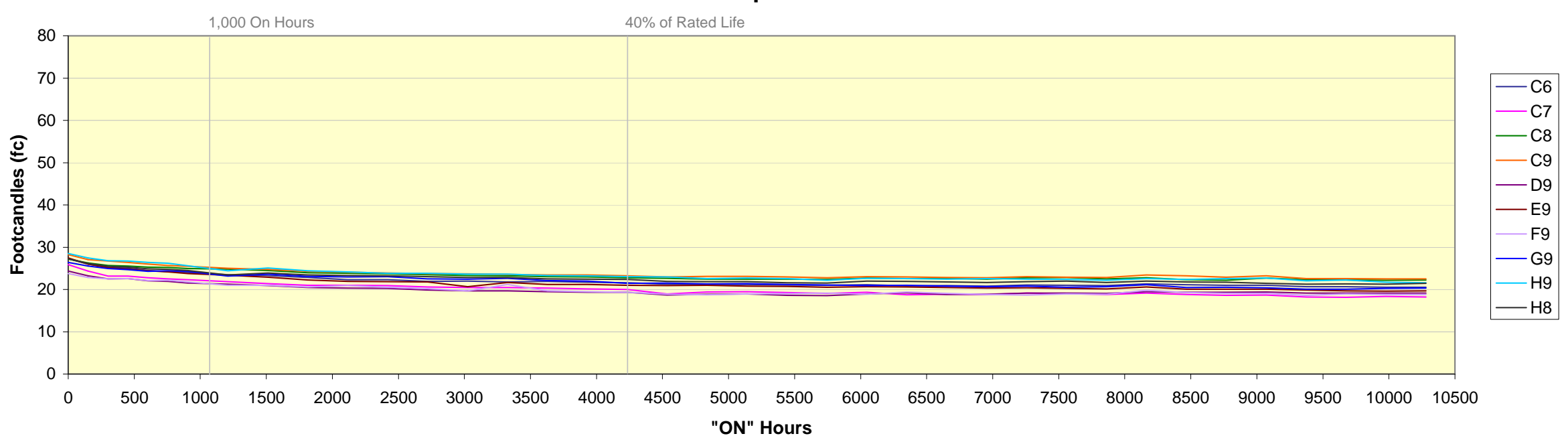

\section{Average Lumen Maintenance}

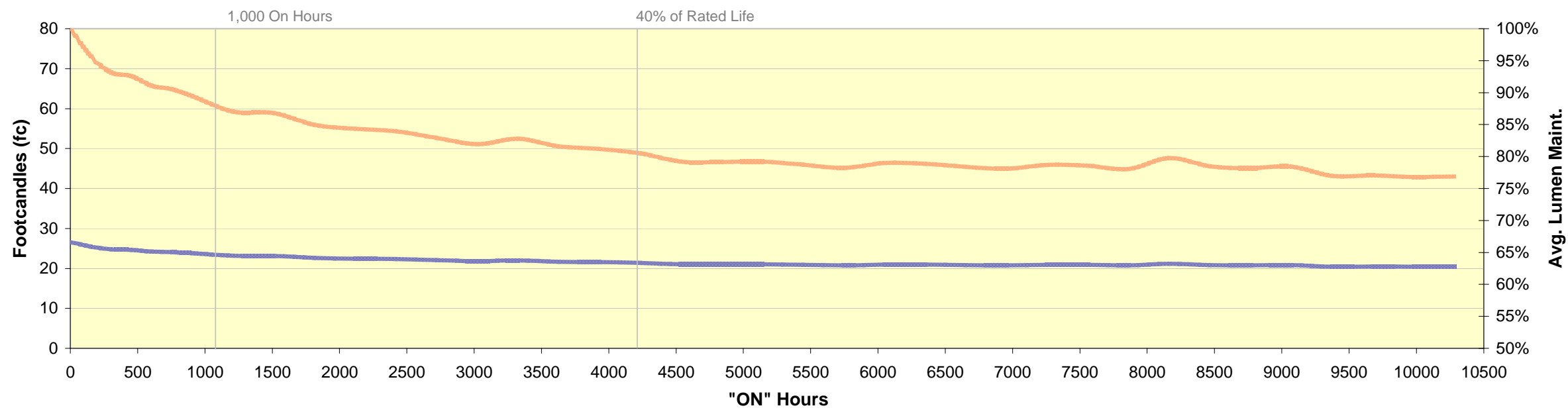




\section{$\underset{\text { Pacerated by Battelle for the u.s. Department of Energy }}{\text { Patory }}$}

Manufacturer: GE

Lamp Model: FLE26/2/R40XL

Test Facility: $\quad$ Luminaire Testing Laboratory, Allentown, PA

Date Provided: 6/5/2008

Test Number: 09262

\section{Life and Lumen Maintenance Report}

\begin{tabular}{|c|c|c|c|c|c|c|c|c|c|c|c|c|c|c|c|c|c|c|c|}
\hline & & & & & & & & UMEN & IINTENA A & E (values & fc) & & & & & & & & \\
\hline Date & $1 / 4 / 06$ & $1 / 11 / 06$ & $1 / 18 / 06$ & $1 / 25 / 06$ & $2 / 1 / 06$ & $2 / 8 / 06$ & $2 / 15 / 06$ & $3 / 1 / 06$ & $3 / 15 / 06$ & $3 / 29 / 06$ & $4 / 12 / 06$ & $4 / 26 / 06$ & $5 / 10 / 06$ & $5 / 24 / 06$ & $6 / 7106$ & $6 / 21 / 06$ & $7 / 5 / 06$ & $7 / 19 / 06$ & $8 / 2 / 06$ \\
\hline "ON" hrs. & 0.0 & 151.2 & 302.4 & 453.6 & 604.8 & 756.0 & 907.2 & 1209.6 & 1512.0 & 1814.4 & 2116.8 & 2419.2 & 2721.6 & 3024.0 & 3326.4 & 3628.8 & 3931.2 & 4233.6 & 4536.0 \\
\hline \multicolumn{20}{|l|}{ Lamp Cell } \\
\hline $\mathrm{H} 3$ & 54.00 & 52.83 & 52.54 & 52.34 & 50.80 & 50.64 & 49.58 & 49.31 & 48.59 & 46.27 & 46.39 & 46.11 & 45.04 & 44.95 & 45.03 & 43.86 & 43.29 & 42.63 & 42.57 \\
\hline 13 & 50.70 & 49.46 & 49.14 & 48.97 & 47.64 & 47.18 & 46.33 & 46.34 & 45.63 & 43.34 & 43.43 & 42.97 & 42.19 & 41.82 & 41.52 & 40.58 & 40.68 & 40.43 & 40.27 \\
\hline 14 & 53.30 & 51.24 & 50.29 & 49.51 & 47.89 & 47.01 & 45.98 & 46.01 & 46.01 & 43.09 & 43.27 & 42.78 & 41.89 & 41.60 & 41.89 & 41.38 & 40.65 & 40.24 & 40.16 \\
\hline 15 & 54.36 & 52.45 & 51.46 & 50.60 & 49.02 & 48.51 & 47.70 & 47.62 & 47.31 & 45.02 & 44.34 & 44.78 & 43.14 & 43.37 & 44.19 & 42.09 & 42.15 & 40.94 & 40.83 \\
\hline 16 & 53.39 & 52.51 & 51.26 & 51.22 & 50.54 & 49.64 & 49.36 & 48.74 & 47.77 & 46.25 & 46.58 & 45.95 & 45.33 & 45.21 & 45.59 & 44.68 & 43.59 & 42.98 & 42.79 \\
\hline 17 & 49.30 & 47.75 & 47.31 & 46.79 & 45.75 & 45.44 & 43.93 & 44.05 & 43.14 & 40.23 & 40.08 & 39.13 & 39.08 & 39.23 & 39.39 & 39.99 & 38.38 & 36.44 & 36.37 \\
\hline 18 & 46.15 & 45.55 & 45.02 & 44.01 & 42.78 & 42.98 & 41.50 & 42.10 & 40.51 & 38.79 & 39.16 & 38.11 & 37.96 & 38.14 & 36.78 & 37.19 & 36.81 & 35.29 & 35.23 \\
\hline 19 & 53.21 & 51.47 & 50.82 & 49.85 & 48.02 & 47.78 & 46.43 & 46.31 & 46.16 & 43.52 & 42.98 & 43.12 & 42.35 & 41.95 & 42.24 & 42.10 & 40.97 & 40.30 & 40.60 \\
\hline $\mathrm{H} 9$ & 49.39 & 47.62 & 46.80 & 46.02 & 44.06 & 43.70 & 42.65 & 42.81 & 41.93 & 39.88 & 39.60 & 39.05 & 38.25 & 38.93 & 38.63 & 38.05 & 37.79 & 36.87 & 37.35 \\
\hline $\mathrm{H} 7$ & 53.45 & 52.11 & 51.78 & 50.97 & 49.78 & 49.18 & 48.09 & 48.18 & 47.64 & 45.00 & 44.97 & 44.77 & 44.04 & 44.23 & 44.46 & 43.77 & 43.62 & 42.74 & 42.88 \\
\hline
\end{tabular}

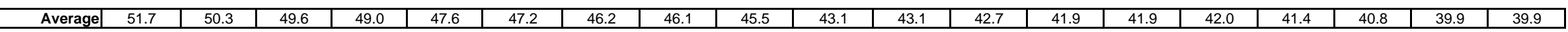

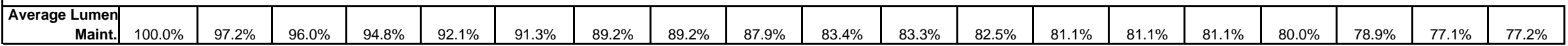

\begin{tabular}{|c|c|c|c|c|c|c|c|c|c|c|c|c|c|c|c|c|c|c|c|}
\hline \multicolumn{20}{|c|}{ LUMEN MAINTENANCE (values in fc) continued } \\
\hline Date & $8 / 16 / 06$ & $8 / 30 / 06$ & $9 / 13 / 06$ & 9/27/06 & $10 / 11 / 06$ & $10 / 25 / 06$ & $11 / 8 / 06$ & $11 / 22 / 06$ & $12 / 6 / 06$ & $12 / 20 / 06$ & $1 / 3 / 07$ & $1 / 17 / 07$ & $1 / 31 / 07$ & $2 / 14 / 07$ & $2 / 28 / 07$ & $3 / 14 / 07$ & $3 / 28 / 07$ & $4 / 11 / 07$ & $4 / 25 / 07$ \\
\hline "ON" hrs. & 4838.4 & 5140.8 & 5443.2 & 5745.6 & 6048.0 & 6350.4 & 6652.8 & 6955.2 & 7257.6 & 7560.0 & 7862.4 & 8164.8 & 8467.2 & 8769.6 & 9072.0 & 9374.4 & $\begin{array}{l}9676.8 \\
\end{array}$ & 9979.2 & 10281.6 \\
\hline \multicolumn{20}{|l|}{ Lamp Cell } \\
\hline $\mathrm{H} 3$ & 41.94 & 41.82 & 42.08 & 42.16 & 43.41 & 43.78 & 43.25 & 43.41 & 43.20 & 42.76 & 43.24 & 44.12 & 43.61 & 43.39 & 44.39 & 42.53 & 42.64 & 42.11 & 41.58 \\
\hline 13 & 40.03 & 39.39 & 38.85 & 38.59 & 38.84 & 38.94 & 37.74 & 38.48 & 38.42 & 38.19 & 38.70 & 38.37 & 39.84 & 39.48 & 39.50 & 38.43 & 38.11 & 38.02 & 38.26 \\
\hline 14 & 39.90 & 39.73 & 39.17 & 38.93 & 39.41 & 39.03 & 38.42 & 38.71 & 38.58 & 38.82 & 37.97 & 38.80 & 38.31 & 38.21 & 38.28 & 38.35 & 38.31 & 38.62 & 38.21 \\
\hline 15 & 40.98 & 40.65 & 40.36 & 39.71 & 40.88 & 40.92 & 40.24 & 40.70 & 40.50 & 40.58 & 40.00 & 40.60 & 40.98 & 40.93 & 40.83 & 39.42 & 39.26 & 39.78 & 38.85 \\
\hline 16 & 42.65 & 42.48 & 42.37 & 42.52 & 42.21 & 42.08 & 41.65 & 41.80 & 42.57 & 43.02 & 42.75 & 43.41 & 43.94 & 42.90 & 43.14 & 41.98 & 42.05 & 41.66 & 42.01 \\
\hline 17 & 36.79 & 36.40 & 36.04 & 35.40 & 36.36 & 36.55 & 35.73 & 35.43 & 35.83 & 36.12 & 35.25 & 36.34 & 36.07 & 35.46 & 35.56 & 34.44 & 34.18 & 34.09 & 33.71 \\
\hline 18 & 34.51 & 35.41 & 33.94 & 33.91 & 34.02 & 35.32 & 36.16 & 35.93 & 36.15 & 35.76 & 35.31 & 35.73 & 35.58 & 34.75 & 36.03 & 33.53 & 33.37 & 33.75 & 32.79 \\
\hline 19 & 39.35 & 40.20 & 39.13 & 39.22 & 39.90 & 40.11 & 39.50 & 38.93 & 39.51 & 39.85 & 38.72 & 39.80 & 39.07 & 39.52 & 40.84 & 38.71 & 38.00 & 38.66 & 38.40 \\
\hline $\mathrm{H} 9$ & 37.01 & 36.18 & 36.25 & 34.87 & 35.37 & 35.32 & 36.01 & 35.76 & 35.35 & 35.64 & 35.03 & 37.21 & 36.73 & 36.97 & 36.97 & 35.08 & 35.45 & 35.19 & 35.43 \\
\hline $\mathrm{H} 7$ & 42.60 & 42.06 & 41.69 & 41.42 & 42.02 & 41.40 & 40.95 & 40.62 & 41.41 & 42.11 & 41.30 & 42.05 & 42.98 & 41.85 & 43.29 & 41.91 & 41.34 & 41.49 & 41.08 \\
\hline
\end{tabular}

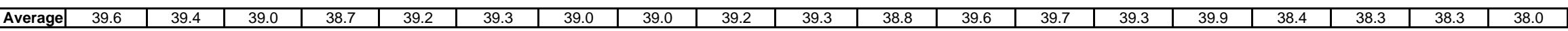

\begin{tabular}{|c|c|c|c|c|c|c|c|c|c|c|c|c|c|c|c|c|c|c|c|}
\hline Average Lumen & $76.5 \%$ & $76.3 \%$ & $75.4 \%$ & $748 \%$ & $75.9 \%$ & $761 \%$ & $75.4 \%$ & $75.4 \%$ & $75.7 \%$ & $76.0 \%$ & $75.1 \%$ & $76.7 \%$ & $76.8 \%$ & $76.1 \%$ & $771 \%$ & $74.3 \%$ & $74.0 \%$ & $74.2 \%$ & $736 \%$ \\
\hline
\end{tabular}

Comments:

Successfully completed 10,000 hours Elevated Temperature Life Testing 


\section{$\underset{\text { Pacerated by Battelle for the U.S. Department of Energy }}{\text { Patory }}$}

\section{Individual Lamp Illuminance and Life}

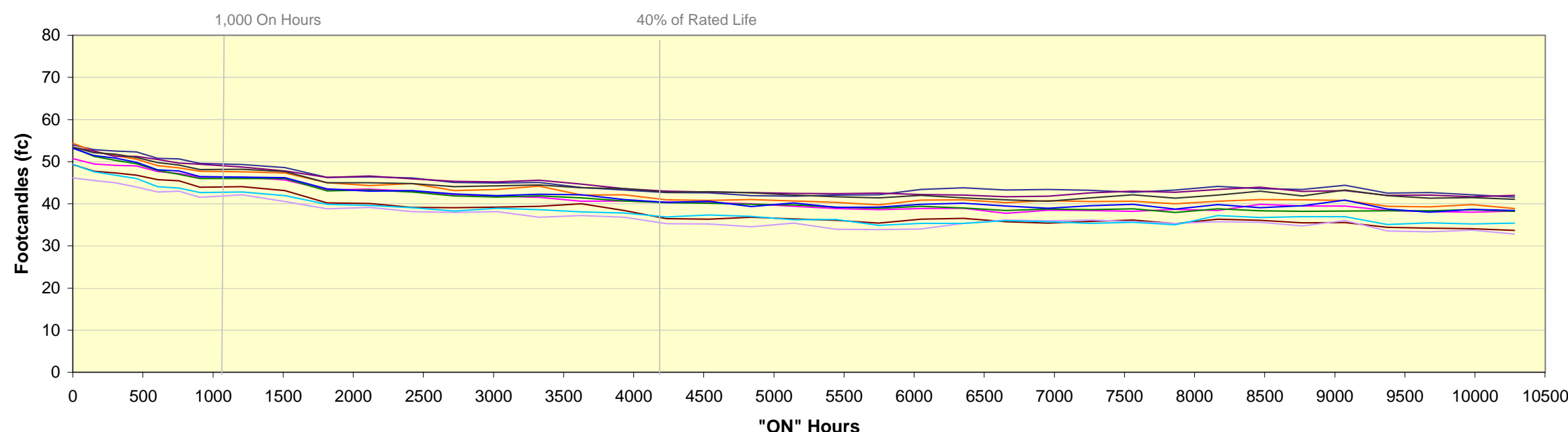

Average Lumen Maintenance

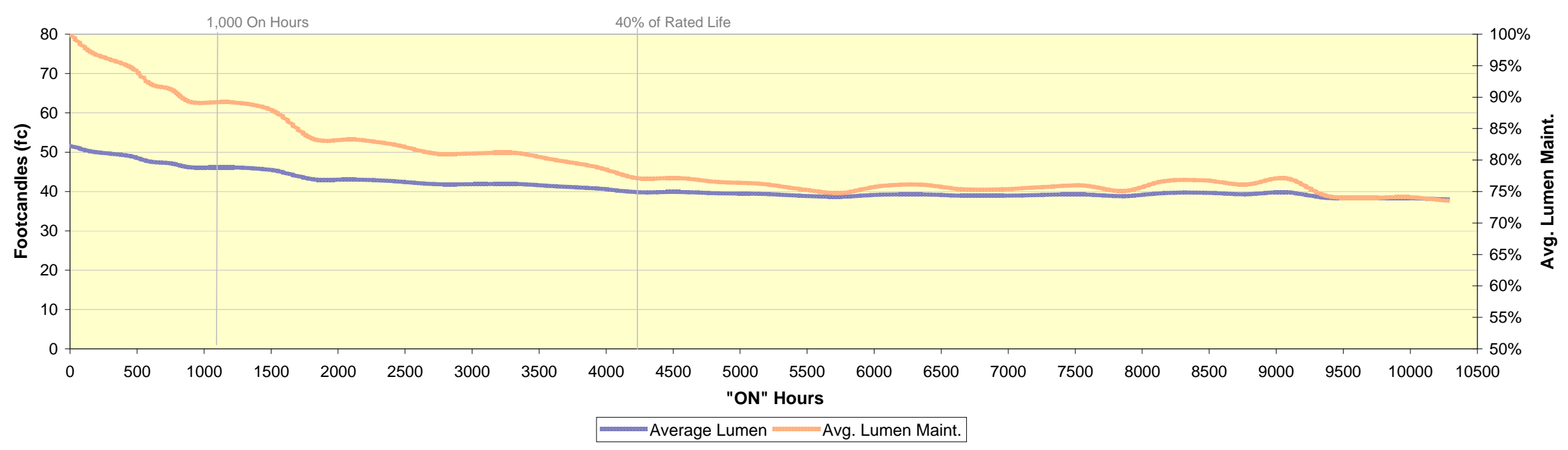




\section{Pacific Northwest National Laboratory}

Manufacturer: GE

Lamp Model: FLE26/2/PAR38/XL

Test Facility: - Luminaire Testing Laboratory, Allentown, PA

Date Provided: 6/5/2008

Test Number: 09331

\section{Life and Lumen Maintenance Report}

\begin{tabular}{|c|c|c|c|c|c|c|c|c|c|c|c|c|c|c|c|c|c|c|c|}
\hline \multicolumn{20}{|c|}{ LUMEN MAINTENANCE (values in fc) } \\
\hline Date & $1 / 4 / 06$ & $1 / 11 / 06$ & $1 / 18 / 06$ & $1 / 25 / 06$ & $2 / 1 / 06$ & $2 / 8 / 06$ & $2 / 15 / 06$ & $3 / 1 / 06$ & $3 / 15 / 06$ & $3 / 29 / 06$ & $4 / 12 / 06$ & $4 / 26 / 06$ & $5 / 10 / 06$ & $5 / 24 / 06$ & $6 / 7 / 06$ & $6 / 21 / 06$ & $7 / 5 / 06$ & $7 / 19 / 06$ & $8 / 2 / 06$ \\
\hline "ON" hrs. & 0.0 & 151.2 & 302.4 & 453.6 & 604.8 & 756.0 & 907.2 & 1209.6 & 1512.0 & \begin{tabular}{|l|l|}
1814.4 \\
\end{tabular} & 2116.8 & 2419.2 & 2721.6 & 3024.0 & 3326.4 & $\begin{array}{l}3628.8 \\
\end{array}$ & 3931.2 & 4233.6 & 4536.0 \\
\hline \multicolumn{20}{|l|}{ Lamp Cell } \\
\hline B2 & 44.14 & 41.66 & 40.56 & 39.94 & 39.18 & 38.77 & 37.86 & 37.10 & 36.45 & 35.46 & 35.03 & 34.77 & 34.20 & 33.58 & 33.72 & 33.17 & 32.95 & 32.76 & 32.47 \\
\hline B3 & 47.04 & 45.53 & 43.21 & 43.91 & 43.30 & 43.21 & 42.47 & 42.09 & 41.35 & 40.37 & 40.30 & 40.03 & 39.64 & 39.01 & 39.13 & 38.96 & 38.72 & 38.43 & 37.62 \\
\hline B4 & 47.26 & 45.09 & 43.29 & 43.30 & 42.49 & 42.16 & 41.18 & 40.89 & 39.88 & 38.60 & 38.29 & 37.97 & 37.55 & 36.82 & 37.16 & 36.69 & 35.54 & 35.84 & 35.35 \\
\hline B5 & 45.44 & 42.95 & 42.37 & 42.09 & 41.71 & 41.58 & 41.42 & 40.46 & 40.10 & 39.53 & 39.52 & 39.19 & 39.15 & 38.34 & 38.15 & 38.54 & 37.95 & 37.92 & $\begin{array}{ll}37.48 \\
\end{array}$ \\
\hline B6 & 45.58 & 43.19 & 41.53 & 41.36 & 40.90 & 40.66 & 40.06 & 39.59 & 39.11 & 38.18 & 37.70 & 37.49 & 37.07 & 36.51 & 36.66 & 36.32 & 36.05 & 35.37 & 35.11 \\
\hline B7 & 48.41 & 46.50 & 44.87 & 45.23 & 44.39 & 44.98 & 44.43 & 44.30 & 43.18 & 41.95 & 42.41 & 41.83 & 41.27 & 40.92 & 40.78 & 40.25 & 39.57 & 39.30 & 38.26 \\
\hline B8 & 45.44 & 44.20 & 43.34 & 43.11 & 42.72 & 42.83 & 42.19 & 41.73 & 41.31 & 40.42 & 40.19 & 39.76 & 39.32 & 38.86 & 38.87 & 38.83 & 38.46 & 37.98 & 37.58 \\
\hline B9 & 45.02 & 43.15 & 41.98 & 41.29 & 40.64 & 40.70 & 39.97 & 39.41 & 39.15 & 38.26 & 38.08 & 37.73 & 37.94 & 37.23 & 37.58 & 36.57 & 36.10 & 35.83 & 35.70 \\
\hline $\mathrm{G} 2$ & 44.83 & 42.82 & 41.25 & 41.10 & 40.50 & 40.26 & 39.59 & 39.05 & 38.62 & 37.61 & 37.22 & 36.94 & 36.69 & 35.91 & 35.76 & 36.47 & 35.97 & 35.13 & 34.92 \\
\hline $\mathrm{H} 2$ & 43.45 & 41.29 & 40.32 & 40.24 & 39.72 & 39.76 & 39.30 & 39.24 & 38.78 & 37.92 & $\begin{array}{l}37.87 \\
\end{array}$ & 37.75 & 37.54 & 37.32 & 37.40 & $\begin{array}{l}37.37 \\
\end{array}$ & 36.70 & 36.26 & 36.17 \\
\hline
\end{tabular}

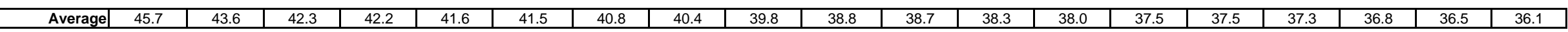

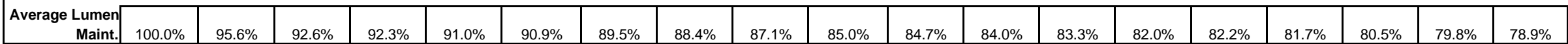

\begin{tabular}{|c|c|c|c|c|c|c|c|c|c|c|c|c|c|c|c|c|c|c|c|}
\hline \multicolumn{20}{|c|}{ LUMEN MAINTENANCE (values in fc) continued } \\
\hline Date & $8 / 16 / 06$ & $8 / 30 / 06$ & 9/13/06 & 9/27/06 & $10 / 11 / 06$ & $10 / 25 / 06$ & $11 / 8 / 06$ & $11 / 22 / 06$ & $12 / 6 / 06$ & $12 / 20 / 06$ & $1 / 3 / 07$ & $1 / 17 / 07$ & $1 / 31 / 07$ & $2 / 14 / 07$ & $2 / 28 / 07$ & $3 / 14 / 07$ & $3 / 28 / 07$ & $4 / 11 / 07$ & $4 / 25 / 07$ \\
\hline "ON" hrs. & 4838.4 & 5140.8 & 5443.2 & 5745.6 & 6048.0 & 6350.4 & 6652.8 & 6955.2 & 7257.6 & 7560.0 & 7862.4 & 8164.8 & 8467.2 & 8769.6 & 9072.0 & 9374.4 & 9676.8 & 9979.2 & 10281.6 \\
\hline \multicolumn{20}{|l|}{ Lamp Cell } \\
\hline B2 & 32.12 & 32.34 & 31.62 & 31.40 & 31.51 & 31.91 & 31.27 & 31.46 & 31.70 & 31.99 & 31.65 & 31.88 & 32.12 & 31.85 & 31.89 & 31.08 & 31.13 & 30.94 & 31.04 \\
\hline \multicolumn{20}{|l|}{ B3 } \\
\hline B4 & 35.47 & 34.98 & 34.22 & 34.31 & 34.49 & 35.18 & 34.81 & 34.40 & 34.90 & 34.04 & 34.70 & 35.64 & 35.12 & 34.43 & 34.64 & 33.73 & 33.68 & 33.43 & 33.86 \\
\hline B5 & 37.11 & 37.26 & 37.26 & 36.90 & 37.21 & 37.54 & 37.05 & 37.00 & 37.50 & 37.43 & 36.75 & 37.76 & 37.47 & 37.14 & 37.06 & 36.10 & 35.86 & 36.05 & 35.91 \\
\hline B6 & 34.67 & 34.66 & 34.02 & 33.97 & 34.09 & 34.32 & 33.90 & 33.70 & 34.46 & 34.23 & 33.93 & 34.37 & 33.86 & 33.90 & 34.20 & 33.39 & 33.39 & 33.32 & 33.35 \\
\hline B7 & 38.08 & 38.14 & 37.66 & 36.80 & 36.81 & 37.97 & 37.01 & 37.06 & 37.70 & 37.25 & 37.04 & 37.48 & 36.99 & 36.51 & 37.31 & 36.05 & 35.99 & 36.17 & 36.89 \\
\hline B8 & 36.99 & 37.37 & 37.00 & 36.50 & 36.86 & 36.63 & 36.23 & 36.08 & 36.61 & 36.67 & 36.45 & 36.82 & 36.60 & 36.19 & 36.33 & 35.51 & 35.51 & 24.87 & 22.50 \\
\hline B9 & 35.35 & 35.68 & 35.55 & 34.91 & 35.10 & 35.02 & 34.16 & 34.09 & 34.64 & 34.60 & 34.73 & 35.17 & 34.60 & 34.30 & 34.57 & 33.55 & 33.64 & 33.90 & 33.69 \\
\hline G2 & 34.12 & 33.53 & 34.05 & 33.79 & 34.23 & 33.71 & 33.73 & 33.12 & 33.83 & 33.96 & 34.18 & 34.70 & 33.71 & 34.46 & 33.77 & 33.23 & 32.63 & 24.29 & 24.78 \\
\hline $\mathrm{H} 2$ & 35.72 & 35.66 & 35.21 & 35.15 & 35.30 & 35.32 & 35.50 & 35.14 & 35.89 & 35.92 & 35.14 & 35.59 & 35.74 & 35.17 & 35.19 & 34.81 & 34.98 & 34.75 & 34.86 \\
\hline
\end{tabular}

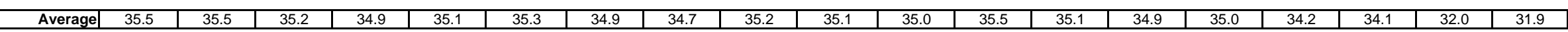

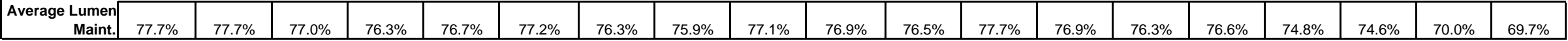

Comments: Lamp Cell B3 Failed on 8/4/06 at $4499.3 \mathrm{hrs}$

Successfully completed 10,000 hours Elevated Temperature Life Testing 


\section{Pacific Northwest National Laboratory}

Manufacturer: $\quad \mathrm{GE}$

Lamp Model: $\quad$ FLE26/2/PAR38/XL

Test Facility: $\quad$ Luminaire Testing Laboratory, Allentown, PA

Date Provided: $\quad 6 / 5 / 2008$
$40 \%$ of Rated Life

\section{Individual Lamp Illuminance and Life}

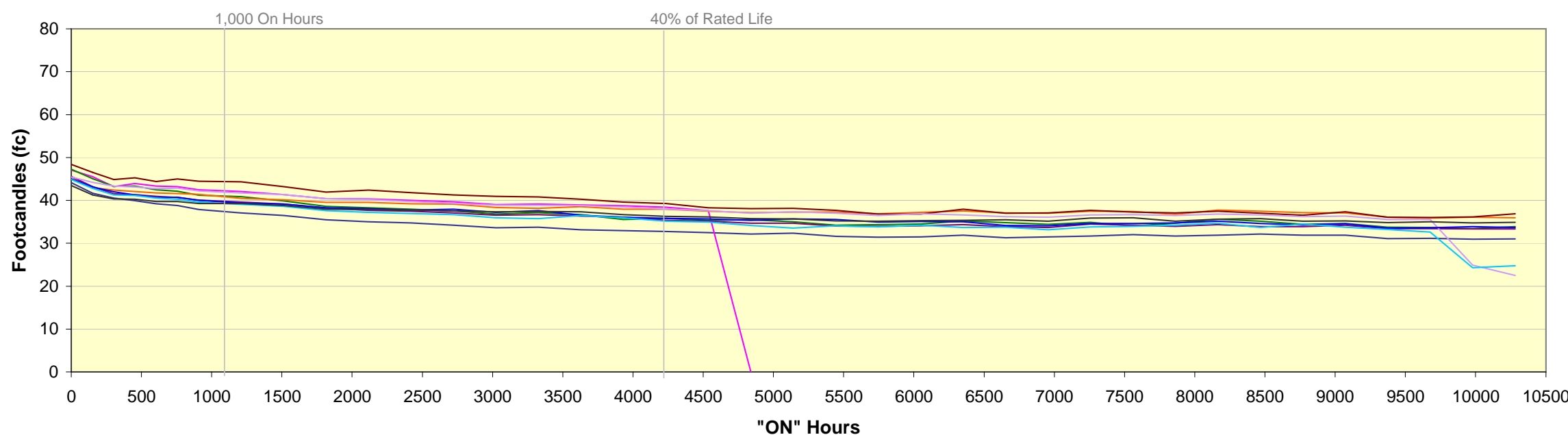

\section{Average Lumen Maintenance}

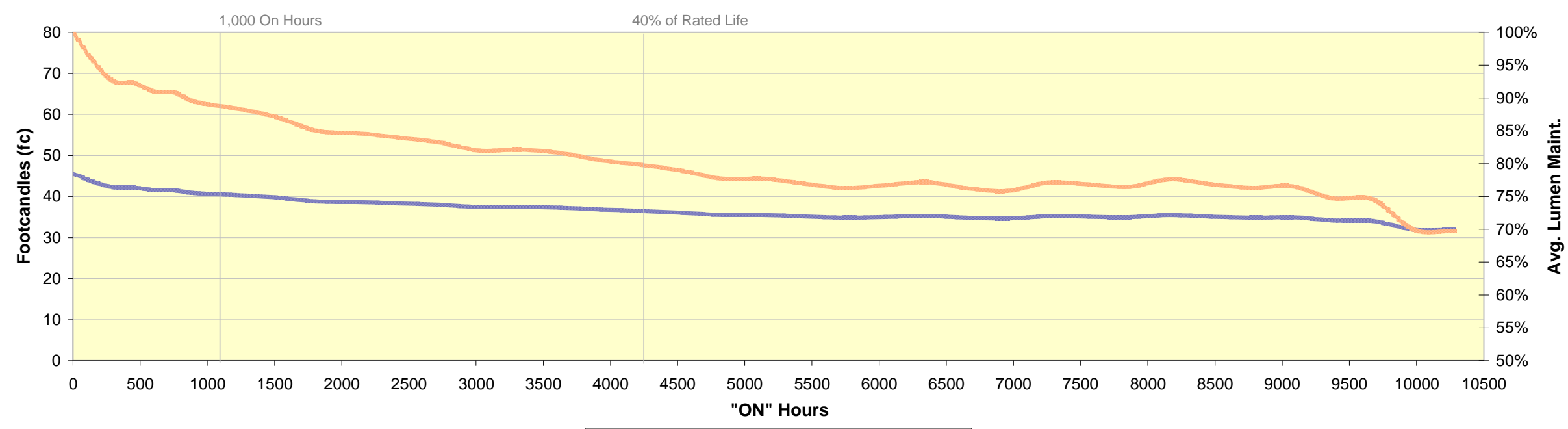

Average Lumen $=$ Avg. Lumen Maint. 


\section{Life and Lumen Maintenance Report}

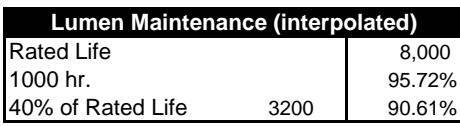

\begin{tabular}{|c|c|c|c|c|c|c|c|c|c|c|c|c|c|c|c|c|c|c|c|}
\hline & & & & & & & & UA & INTE & E & & & & & & & & & \\
\hline Date & $1 / 4 / 06$ & $1 / 11 / 06$ & $1 / 18 / 06$ & $1 / 25 / 06$ & $2 / 1 / 06$ & $2 / 8 / 06$ & $2 / 15 / 06$ & $3 / 1 / 06$ & $3 / 15 / 06$ & $3 / 29 / 06$ & $4 / 12 / 06$ & $4 / 26 / 06$ & $5 / 10 / 06$ & $5 / 24 / 06$ & $6 / 7 / 06$ & $6 / 21 / 06$ & $7 / 5 / 06$ & $7 / 19 / 06$ & $8 / 2 / 06$ \\
\hline "ON" hrs. & 0.0 & 151.2 & 302.4 & 453.6 & 604.8 & 756.0 & 907.2 & 1209.6 & 1512.0 & 1814.4 & 2116.8 & 2419.2 & 2721.6 & 3024.0 & 3326.4 & 3628.8 & 3931.2 & 4233.6 & 4536.0 \\
\hline Lamp Cell & & & & & & & & & & & & & & & & & & & \\
\hline B7 & 56.51 & 55.88 & 55.50 & 55.09 & 54.63 & 54.23 & 53.48 & 53.60 & 53.37 & 51.64 & 51.87 & 51.40 & 51.67 & 51.35 & 50.93 & 49.83 & 50.17 & 49.58 & 49.44 \\
\hline B6 & 57.01 & 56.49 & 56.21 & 56.06 & 55.35 & 54.88 & 53.80 & 53.84 & 53.42 & 51.13 & 51.84 & 51.23 & 49.67 & 49.65 & 50.28 & 48.90 & 49.25 & 48.76 & 48.35 \\
\hline B5 & 57.91 & 57.05 & 56.41 & 56.51 & 55.76 & 55.50 & 54.91 & 54.81 & 54.46 & 52.72 & 52.81 & 52.47 & 51.53 & 50.86 & 51.21 & 49.86 & 49.54 & 49.86 & 49.34 \\
\hline B4 & 55.43 & 54.50 & 53.80 & 54.05 & 53.87 & 53.60 & 53.16 & 53.05 & 52.97 & 51.28 & 51.45 & 51.04 & 50.38 & 50.45 & 50.97 & 49.51 & 49.23 & 48.58 & 48.43 \\
\hline B3 & 57.60 & 56.61 & 56.52 & 56.47 & 55.84 & 55.63 & 55.03 & 55.07 & 54.68 & 53.20 & 53.09 & 52.72 & 52.27 & 52.44 & 52.90 & 51.23 & 51.04 & 50.58 & 50.55 \\
\hline C3 & 58.58 & 58.09 & 58.05 & 57.71 & 57.49 & 57.23 & 56.30 & 56.05 & 55.18 & 53.74 & 53.74 & 52.75 & 51.64 & 51.11 & 52.01 & 50.79 & 50.63 & 50.24 & 50.22 \\
\hline E3 & 59.02 & 58.58 & 58.38 & 58.25 & 58.07 & 57.73 & 57.30 & 57.21 & 57.31 & 56.00 & 55.82 & 55.86 & 55.52 & 55.67 & 54.73 & 53.59 & 53.50 & 53.39 & 53.37 \\
\hline F3 & 54.65 & 54.32 & 54.07 & 53.68 & 53.55 & 53.39 & 52.82 & 53.14 & 52.47 & 51.10 & 50.99 & 50.19 & 50.18 & 50.36 & 50.75 & 49.23 & 48.91 & 48.60 & 47.80 \\
\hline D3 & 58.62 & 57.81 & 57.47 & 57.39 & 56.91 & 56.68 & 56.14 & 56.10 & 55.70 & 54.16 & 53.90 & 53.56 & 53.00 & 53.13 & 53.25 & 51.68 & 51.24 & 50.64 & 50.49 \\
\hline G3 & 52.87 & 52.51 & 53.58 & 52.97 & 52.10 & 51.84 & 50.97 & 51.02 & 51.34 & 49.17 & 48.61 & 49.10 & 48.34 & 48.25 & 48.99 & 47.9 & 47.71 & 47.2 & 47.17 \\
\hline Average & 56.8 & 56.2 & 56.0 & 55.8 & 55.4 & 55.1 & 54.4 & 54.4 & 54.1 & 52.4 & 52.4 & 52.0 & 51.4 & 51.3 & 51.6 & 50.3 & 50.1 & 49.7 & 49.5 \\
\hline \begin{tabular}{|l|} 
Average Lumen \\
\end{tabular} & & & & & & & & & & & & & & & & & & & \\
\hline Maint. & $100.0 \%$ & $98.9 \%$ & $98.6 \%$ & $98.2 \%$ & $97.4 \%$ & $96.9 \%$ & $95.7 \%$ & $95.7 \%$ & $95.2 \%$ & $92.2 \%$ & $92.2 \%$ & $91.6 \%$ & $90.5 \%$ & $90.3 \%$ & $90.8 \%$ & $88.5 \%$ & $88.2 \%$ & $87.6 \%$ & $87.2 \%$ \\
\hline & & & & & & & LUME & AIN & NCE & $\sin \mathrm{fc})($ & ontinued & & & & & & & & \\
\hline Date & $8 / 16 / 06$ & $8 / 30 / 06$ & $9 / 13 / 06$ & 9/27/06 & 10/11/06 & $10 / 25 / 06$ & $11 / 8 / 06$ & $11 / 22 / 06$ & $12 / 6 / 06$ & $12 / 20 / 06$ & $1 / 3 / 07$ & $1 / 17 / 07$ & $1 / 31 / 07$ & $2 / 14 / 07$ & $2 / 28 / 07$ & $3 / 14 / 07$ & $3 / 28 / 07$ & $4 / 11 / 07$ & $4 / 25 / 07$ \\
\hline "ON" hrs. & 4838.4 & 5140.8 & 5443.2 & 5745.6 & 6048.0 & 6350.4 & 6652.8 & 6955.2 & 7257.6 & 7560.0 & 7862.4 & 8164.8 & 8467.2 & 8769.6 & 9072.0 & 9374.4 & $\begin{array}{l}9676.8 \\
\end{array}$ & 9979.2 & 10281.6 \\
\hline Lamp Cell & & & & & & & & & & & & & & & & & & & \\
\hline B7 & 48.86 & 48.77 & 47.29 & 46.79 & 47.15 & 47.44 & 47.40 & 47.03 & 47.78 & 47.85 & 46.58 & 47.60 & & & & & & & \\
\hline B6 & 47.67 & 47.78 & 46.91 & 46.76 & 47.77 & 47.75 & 46.09 & 46.86 & 46.21 & 47.31 & 46.57 & 47.39 & & & & & & & \\
\hline B5 & 49.39 & 48.27 & 48.64 & 48.57 & 49.01 & 48.37 & 48.47 & 48.35 & 48.76 & 48.59 & 48.26 & 49.07 & & & & & & & \\
\hline B4 & 47.88 & 47.79 & 47.30 & 46.35 & 47.36 & 47.60 & 47.47 & 47.24 & 48.15 & 48.04 & 47.72 & 48.42 & & & & & & & \\
\hline B3 & 49.97 & 49.80 & 49.42 & 49.27 & 49.74 & 49.60 & 49.29 & 48.91 & 49.80 & 49.59 & 49.38 & 50.04 & & & Comp & ted 8000 & burs & & \\
\hline $\mathrm{C} 3$ & 50.01 & 50.10 & 49.57 & 49.30 & 49.64 & 49.32 & 49.12 & 49.18 & 49.82 & 49.87 & 49.33 & 50.07 & & & & & & & \\
\hline E3 & 52.75 & 52.51 & 51.22 & 51.20 & 51.97 & 51.88 & 51.86 & 51.26 & 52.52 & 52.38 & 52.10 & 53.05 & & & & & & & \\
\hline F3 & 47.86 & 47.81 & 47.45 & 47.21 & 47.52 & 47.21 & 47.07 & 46.57 & 46.25 & & & & & & & & & & \\
\hline D3 & 50.12 & 49.92 & 49.58 & 49.32 & 49.80 & 49.48 & 49.16 & 48.80 & 48.83 & 48.53 & 48.58 & 49.35 & & & & & & & \\
\hline G3 & 46.86 & 46.79 & 47.11 & 46.41 & 46.52 & 46.66 & 45.41 & 45.94 & 46.06 & 45.48 & 45.07 & 46.12 & & & & & & & \\
\hline Average & 49.1 & 49.0 & 48.4 & 48.1 & 48.6 & 48.5 & 48.1 & 48.0 & 48.4 & 48.6 & 48.2 & 49.0 & & & & & & & \\
\hline & & & & & & & & & & & & & & & & & & & \\
\hline $\begin{array}{r}\text { e Lumen } \\
\text { Maint. }\end{array}$ & $86.5 \%$ & $86.2 \%$ & $85.3 \%$ & $84.7 \%$ & $85.6 \%$ & $85.4 \%$ & $84.7 \%$ & $84.5 \%$ & $85.2 \%$ & $85.6 \%$ & $84.8 \%$ & $86.3 \%$ & & & & & & & \\
\hline
\end{tabular}

Comments: 


\section{Pacific Northwest National Laboratory}

\section{OSRAM}

Manufacturer: Osram

Lamp Model: CFEL20BR40 20W

Test Facility: $\quad$ Luminaire Testing Laboratory, Allentown, PA

Luminaire

Individual Lamp Illuminance and Life

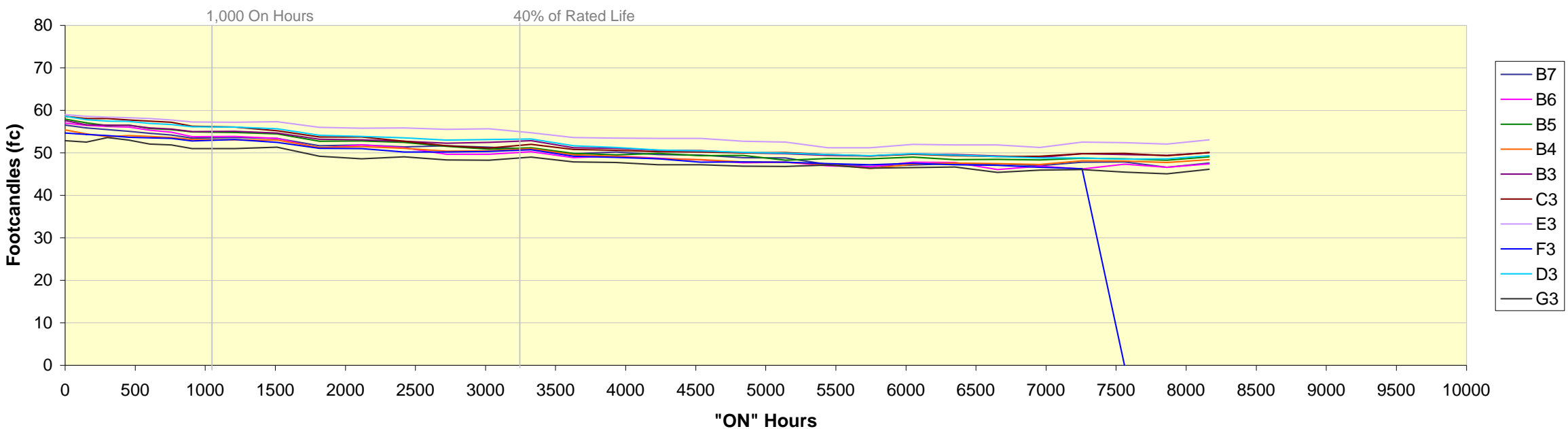

Average Lumen Maintenance

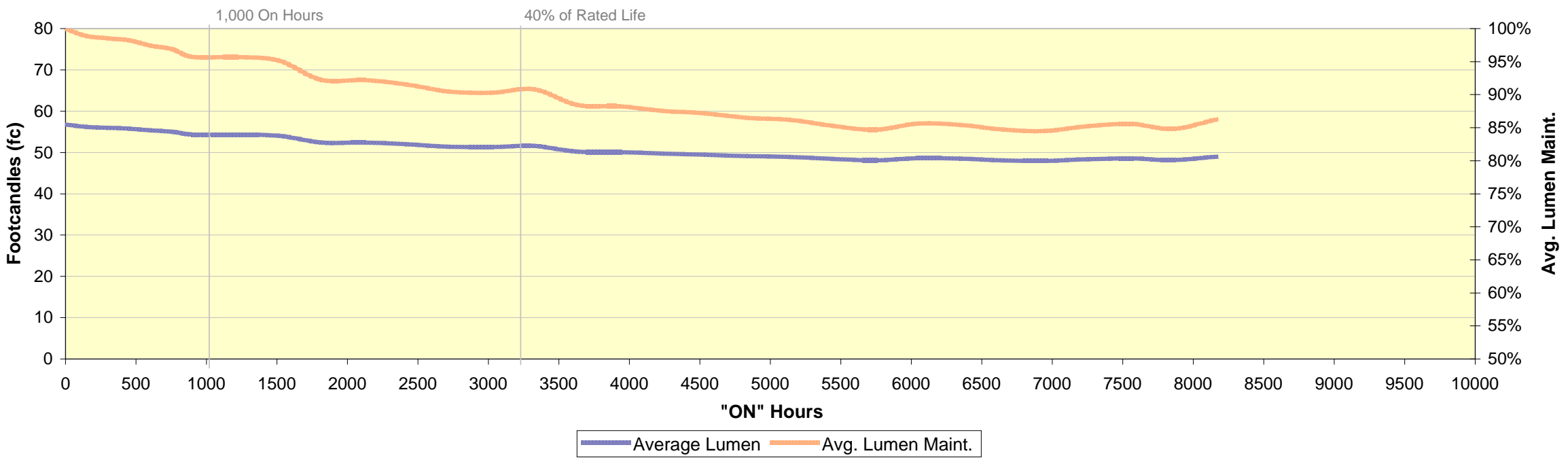




\section{Life and Lumen Maintenance Report}

\section{Rated Life}

$1000 \mathrm{hr}$.

$40 \%$ of Rated Life

\begin{tabular}{|c|c|c|c|c|c|c|c|c|c|c|c|c|c|c|c|c|c|c|c|}
\hline \multicolumn{20}{|c|}{ LUMEN MAINTENANCE (values in $\mathrm{fc}$ ) } \\
\hline Date & $1 / 4 / 06$ & $1 / 11 / 06$ & $1 / 18 / 06$ & $1 / 25 / 06$ & $2 / 1 / 06$ & $2 / 8 / 06$ & $2 / 15 / 06$ & $3 / 1 / 06$ & $3 / 15 / 06$ & $3 / 29 / 06$ & $4 / 12 / 06$ & $4 / 26 / 06$ & $5 / 10 / 06$ & $5 / 24 / 06$ & $6 / 7106$ & $6 / 21 / 06$ & $7 / 5 / 06$ & $7 / 19 / 06$ & $8 / 2 / 06$ \\
\hline "ON" hrs. & 0.0 & 151.2 & 302.4 & 453.6 & $\begin{array}{l}604.8 \\
\end{array}$ & 756.0 & 907.2 & 1209.6 & 1512.0 & $\begin{array}{l}1814.4 \\
\end{array}$ & 2116.8 & 2419.2 & 2721.6 & 3024.0 & 3326.4 & $\begin{array}{l}3628.8 \\
\end{array}$ & 3931.2 & 4233.6 & 4536.0 \\
\hline \multicolumn{20}{|l|}{ Lamp Cell } \\
\hline E7 & 40.16 & 39.27 & 39.05 & 39.80 & 39.15 & 38.68 & 38.03 & 38.01 & 37.58 & 36.30 & 36.19 & 35.91 & 35.45 & 35.49 & 35.76 & 34.64 & 34.31 & 33.85 & 33.45 \\
\hline F7 & 35.61 & 34.93 & 34.93 & 34.26 & 33.52 & 32.98 & 32.37 & 32.20 & 31.80 & 31.00 & 31.16 & 30.70 & 30.42 & 30.31 & 30.46 & 30.21 & 29.86 & 28.42 & 28.94 \\
\hline $\mathrm{G} 7$ & 37.33 & 36.71 & 37.34 & 36.55 & 35.58 & 35.13 & 34.37 & 33.52 & 34.04 & 32.40 & 32.48 & 32.28 & 32.05 & 32.05 & 32.18 & 32.06 & 31.81 & 31.35 & 31.02 \\
\hline $\mathrm{H} 8$ & 40.37 & 39.94 & 39.50 & 39.32 & 38.77 & 38.41 & 37.73 & 37.60 & 37.54 & 36.12 & 36.09 & 35.67 & 35.33 & 35.23 & 35.31 & 34.77 & 34.72 & 34.00 & 33.33 \\
\hline G8 & 43.33 & 42.51 & 42.07 & 41.20 & 40.71 & 40.36 & 39.60 & 39.53 & 39.10 & 37.26 & 37.31 & 36.80 & 36.50 & 36.51 & 36.61 & 37.14 & 36.77 & 35.92 & 35.79 \\
\hline F8 & 38.21 & 37.20 & 36.93 & 36.16 & 35.25 & 34.57 & 33.81 & 33.30 & 33.41 & 31.53 & 31.47 & 31.00 & 30.58 & 30.54 & 30.83 & 30.37 & 30.30 & 29.28 & 29.36 \\
\hline E8 & 42.94 & 42.15 & 42.02 & 41.58 & 40.61 & 40.22 & 39.58 & 39.29 & 38.84 & 37.12 & 37.01 & 36.69 & 36.28 & 36.06 & 37.00 & 36.32 & 36.08 & 35.68 & 35.33 \\
\hline D8 & 42.19 & 41.49 & 41.36 & 41.09 & 39.97 & 39.52 & 38.67 & 38.44 & 37.92 & 36.08 & 35.83 & 35.50 & 35.14 & 34.78 & 34.80 & 34.04 & 33.70 & 32.95 & 32.59 \\
\hline $\mathrm{C} 8$ & 39.77 & 39.01 & 38.68 & 38.36 & 37.50 & 37.12 & 36.46 & 36.12 & 35.97 & 34.49 & 34.42 & 34.04 & 34.04 & 33.98 & 34.13 & 33.21 & 32.86 & 32.81 & 32.58 \\
\hline B8 & 40.88 & 39.67 & 39.13 & 38.86 & $\begin{array}{l}37.94 \\
\end{array}$ & 37.63 & 36.91 & 36.51 & 35.90 & 34.60 & 34.42 & 34.09 & 33.95 & 34.04 & 34.37 & 33.49 & 33.46 & 33.26 & 32.82 \\
\hline
\end{tabular}

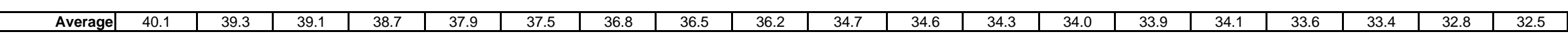

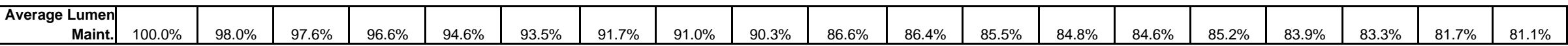

\begin{tabular}{|c|c|c|c|c|c|c|c|c|c|c|c|c|c|c|c|c|c|c|c|}
\hline \multicolumn{20}{|c|}{ LUMEN } \\
\hline "ON" hrs. & 4838.4 & 5140.8 & 5443.2 & 5745.6 & 6048.0 & 6350.4 & $\frac{11 / 0 / 00}{6652.8}$ & $\frac{11 / 22 / 06}{69552}$ & $12 / 6 / 06$ & $12120 / 06$ & $\frac{1 / 3 / 07}{78624}$ & $\frac{1 / 171 / 07}{81648}$ & $\frac{1 / 85101}{84672}$ & 214101 & $\frac{2128 / 07}{90720}$ & $\frac{3114 / 07}{9374.4}$ & $\frac{3128107}{96768}$ & $\frac{4 / 11 / 07}{99792}$ & $\begin{array}{l}4 / 25 / 07 \\
10281.6\end{array}$ \\
\hline \multicolumn{20}{|l|}{ Lamp Cell } \\
\hline E7 & 33.12 & 33.05 & 33.34 & 33.09 & 33.10 & & & & & & & & & & & & & & \\
\hline F7 & 28.53 & 28.67 & 28.56 & 28.34 & 28.61 & & & & & & & & & & & & & & \\
\hline G7 & 30.69 & 30.60 & 30.25 & 30.06 & 30.36 & & & & & & & & & & & & & & \\
\hline $\mathrm{H} 8$ & 33.50 & 33.77 & 33.35 & 33.09 & 33.27 & & & & & & & & & & & & & & \\
\hline G8 & 35.08 & 34.89 & 34.54 & 34.29 & 34.28 & & \multirow{2}{*}{\multicolumn{4}{|c|}{ Completed 6000 hours }} & & & & & & & & & \\
\hline F8 & 28.85 & 28.80 & 28.49 & 28.30 & 28.34 & & & & & & & & & & & & & & \\
\hline E8 & 34.96 & 34.95 & 34.07 & 33.48 & & & & & & & & & & & & & & & \\
\hline D8 & 32.49 & 33.42 & 33.35 & 33.00 & 33.22 & & & & & & & & & & & & & & \\
\hline C8 & 32.27 & 31.94 & 32.16 & 31.77 & 31.48 & & & & & & & & & & & & & & \\
\hline B8 & 32.48 & 32.65 & 32.26 & 31.93 & 32.26 & & & & & & & & & & & & & & \\
\hline Average & 32.2 & 32.3 & 32.0 & 31.7 & 31.7 & & & & & & & & & & & & & & \\
\hline $\begin{array}{r}\text { Average Lumen } \\
\text { Maint. }\end{array}$ & $80.3 \%$ & $80.5 \%$ & $79.9 \%$ & $79.1 \%$ & $78.9 \%$ & & & & & & & & & & & & & & \\
\hline
\end{tabular}

Comments: Lamp Cell E8 Failed on 10/2/06 at 5861.3 hrs 


\section{OSRAM}

\section{Pacific Northwest National Laboratory}

Manufacturer: Osram

Lamp Model: CFE19PAR38 19W

Test Facility: Luminaire Testing Laboratory, Allentown, PA

\section{Individual Lamp Illuminance and Life}
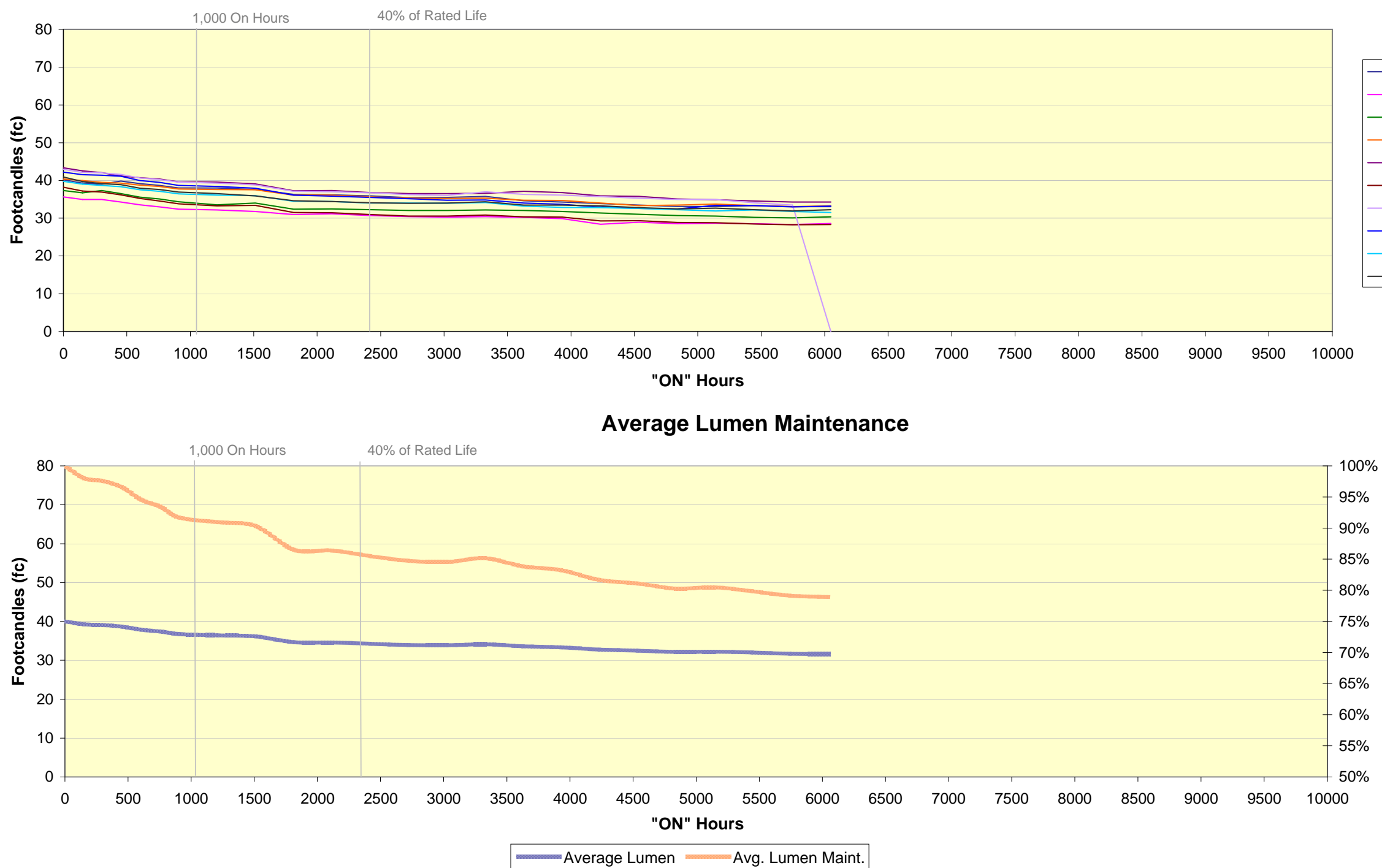
Appendix F

CFL Clean Up 



\section{Appendix F}

\section{CFL Cleanup}

\section{What to Do if a Fluorescent Light Bulb Breaks}

Fluorescent light bulbs contain a very small amount of mercury sealed within the glass tubing. EPA recommends the following clean-up and disposal guidelines:

1. Open a window and leave the room (restrict access) for at least $\mathbf{1 5}$ minutes.

2. Remove all materials you can without using a vacuum cleaner.

o Wear disposable rubber gloves, if available (do not use your bare hands).

o Carefully scoop up the fragments and powder with stiff paper or cardboard.

o Wipe the area clean with a damp paper towel or disposable wet wipe.

o Sticky tape (such as duct tape) can be used to pick up small pieces and powder.

3. Place all cleanup materials in a plastic bag and seal it.

- If your state permits you to put used or broken fluorescent light bulbs in the garbage, seal the bulb in two plastic bags and put into the outside trash (if no other disposal or recycling options are available).

o Wash your hands after disposing of the bag.

4. The first time you vacuum the area where the bulb was broken, remove the vacuum bag once done cleaning the area (or empty and wipe the canister) and put the bag and/or vacuum debris, as well as the cleaning materials, in two sealed plastic bags in the outdoor trash or protected outdoor location for normal disposal.

\section{References:}

U.S. Environmental Protection Agency (EPA) Guidelines - link to www.epa.gov/mercury/spills/index.htm\#flourescent 



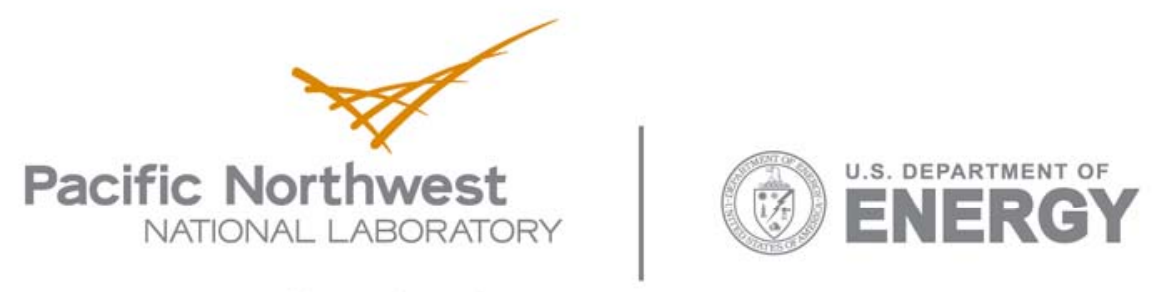

902 Battelle Boulevard

P.O. Box 999

Richland, WA 99352

1-888-375-PNNL (7665)

www.pnl.gov 